\title{
RECLAMATION EFFECTIVENESS AT THREE RECLAIMED ABANDONED MINE SITES IN JEFFERSON COUNTY, MONTANA
}

by

Tara Christine Tafi

A thesis submitted in partial fulfillment of the requirements for the degree

\author{
of \\ Master of Science \\ in \\ Land Rehabilitation \\ MONTANA STATE UNIVERSITY \\ Bozeman, Montana
}

May 2006 
(c) COPYRIGHT

by

Tara Christine Tafi

2006

All Rights Reserved 


\author{
APPROVAL \\ of a thesis submitted by \\ Tara Christine Tafi
}

This thesis has been read by each member of the thesis committee and had been found to be satisfactory regarding content, English usage, format, citations, bibliographic style, and consistency, and is ready for submission to the Division of Graduate Education.

\author{
Dennis Neuman
}

Approved for the Department of Land Resources and Environmental Sciences

Dr. John Wraith

Approved for the Division of Graduate Education

Dr. Joseph Fedock 


\section{STATEMENT OF PERMISSION TO USE}

In presenting this thesis in partial fulfillment of the requirements for a master's degree at Montana State University, I agree that the Library shall make it available to borrowers under rules of the library.

If I have indicated my intention to copyright this thesis by including a copyright notice page, copying is allowable only for scholarly purposes, consistent with "fair use" as prescribed by the U.S. Copyright Law. Requests for permission for extended quotation from or reproduction of this thesis in whole or in parts may be granted only by the copyright holder.

Tara Christine Tafi

May 2006 


\section{ACKNOWLEGEMENTS}

First of all, I would like to thank my major advisor, Dennis Neuman, for his guidance and support during my graduate education. It was Dennis who helped me get this project started and helped me every step of the way, and for this I am forever grateful. I also thank Cathy Zabinski for co-chairing my committee and providing me with the guidance that I needed. Many thanks to Bill Inskeep and Clayton Marlow for sitting on my committee and being enthusiastic about my work.

I would like to express my great appreciation to Stuart Jennings, Pam Blicker, Frank Munshower, and Dawn Major; they have been extremely supportive and helped me greatly during this experience.

I thank Mike Browne (USFS) for his vision and help developing this project, Floyd Thompson (BLM) and Huey Long (BLM) for their help in the field, and the Bureau of Land Management for funding this project. Thanks also to Loren Huggins for his help in the field. I may still be digging soil pits if not for his help.

Finally, I would like to thank my parents, Yolanda and Dennis Tafi, for without whom I would have been completely lost in life and graduate school. They have truly been an inspiration. 
TABLE OF CONTENTS

Page

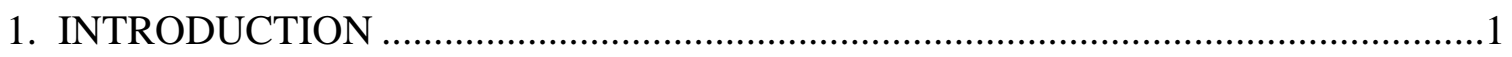

Statement of the Problem.........................................................................................

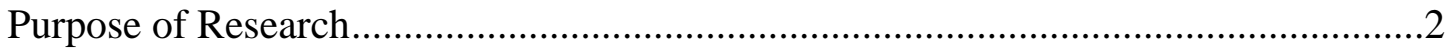

Study Area Description .........................................................................................

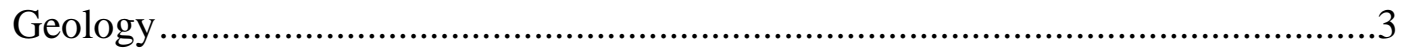

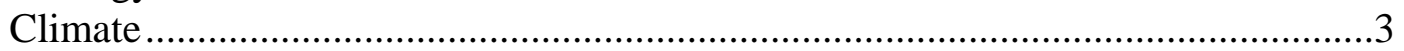

Reclamation Methods …………………………….....................................

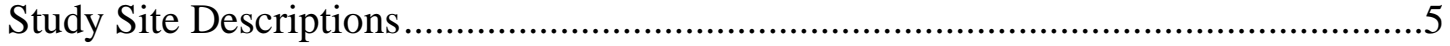

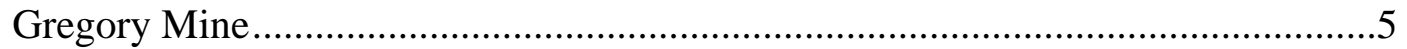

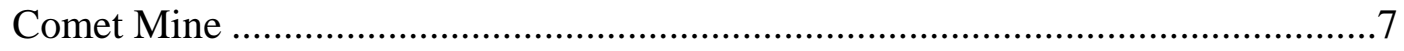

High Ore Creek ……………………….............................................................10

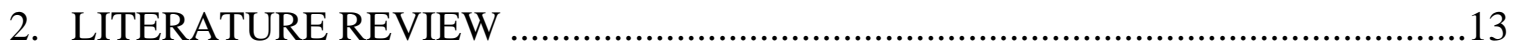

Revegetation and Reclamation Effectiveness ...........................................................13

Metal Tolerant Plants ..................................................................................14

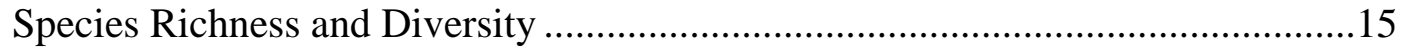

Limiting Factors for Plant Growth..........................................................................17

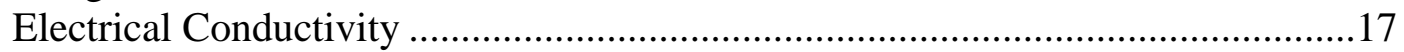

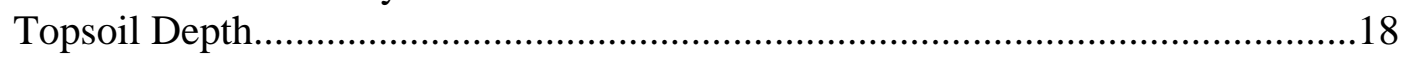

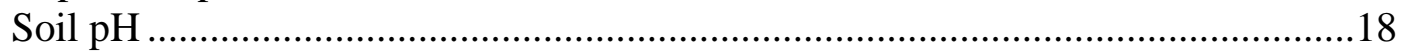

Trace Elements in the Root Zone...................................................................19

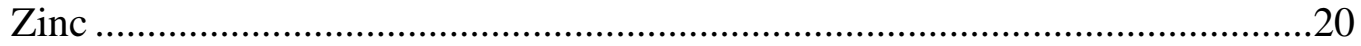

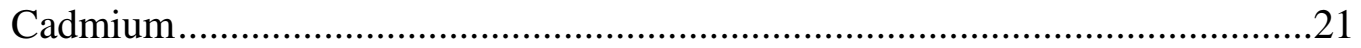

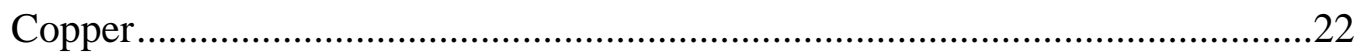

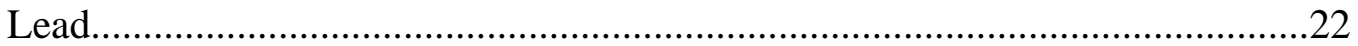

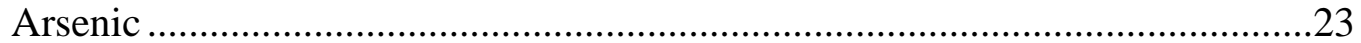

Upward Migration of Contaminants ...................................................................24

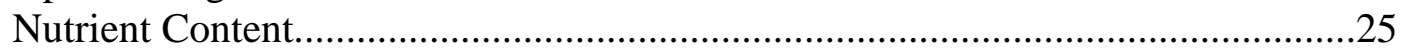

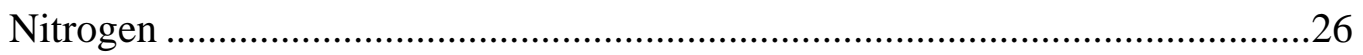

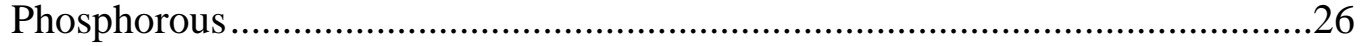

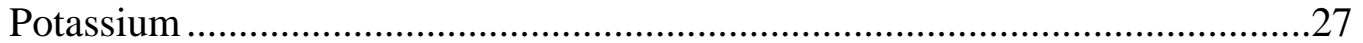

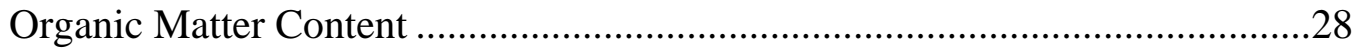

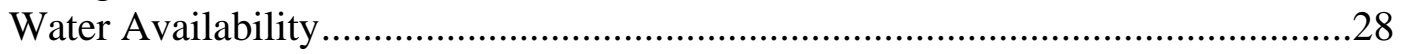




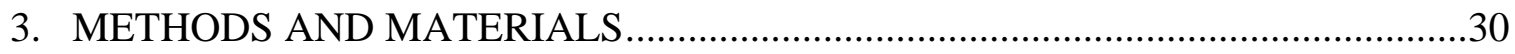

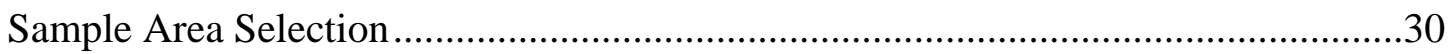

Gregory and Comet Mines....................................................................................

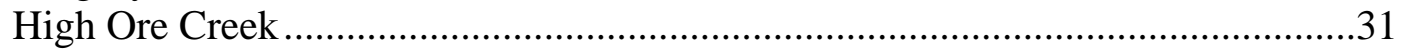

Sampling Design and Analysis ..............................................................................31

Soil Sample Collection .........................................................................................32

Soil Sample Preparation.............................................................................................32

Soil Analytical Procedures...........................................................................................33

Acidity and Electrical Conductivity Determination ................................................33

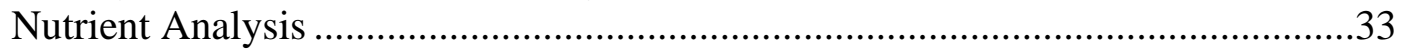

Soluble Metal Analysis ......................................................................................34

Total Recoverable Metals Analysis ........................................................................34

Vegetation Sample Collection and Preparation ............................................................34

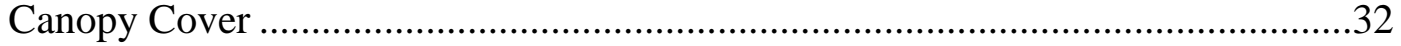

Above Ground Biomass...............................................................................

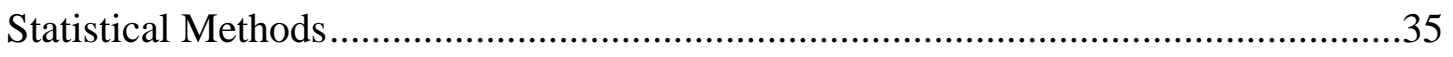

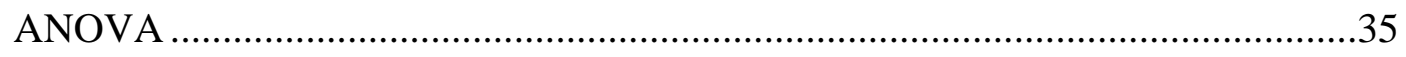

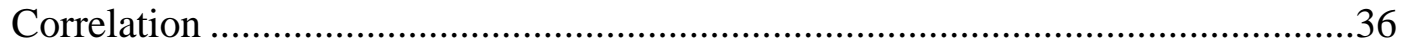

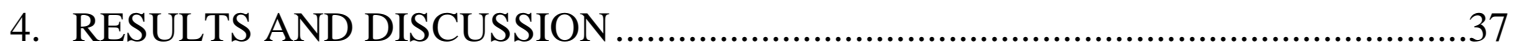

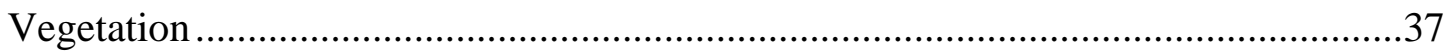

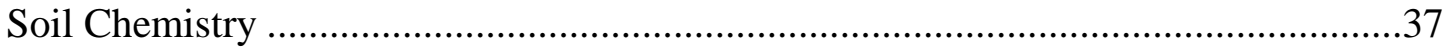

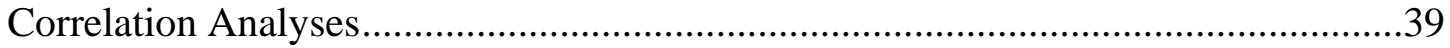

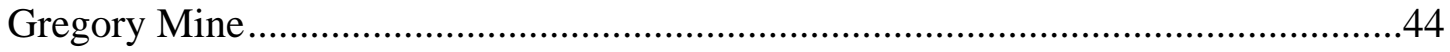

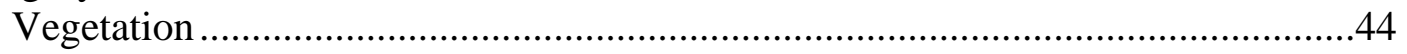

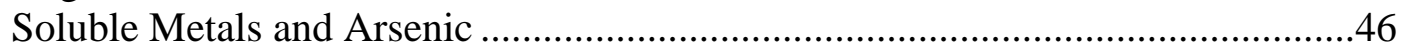

Total Metals and Arsenic ..............................................................................46

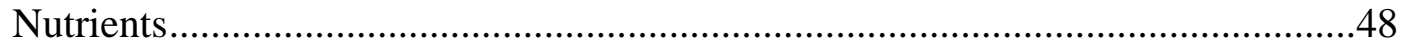

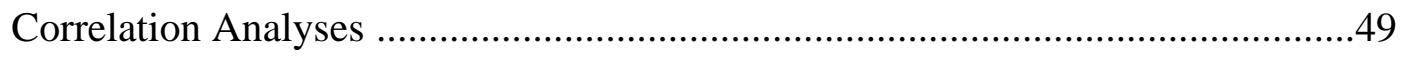

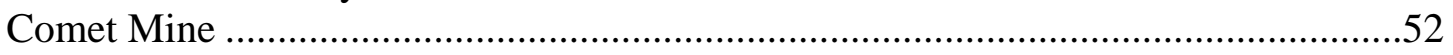

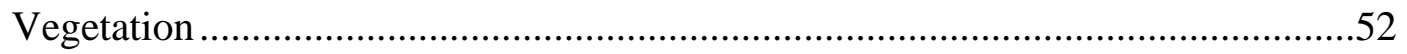

Soluble Metals and Arsenic ...........................................................................53

Total Metals and Arsenic ................................................................................5

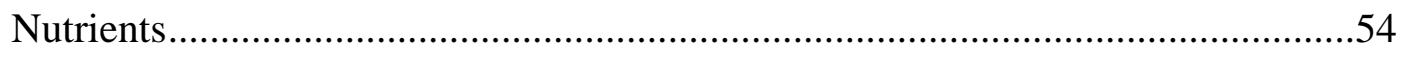

Correlation Analyses...................................................................................56

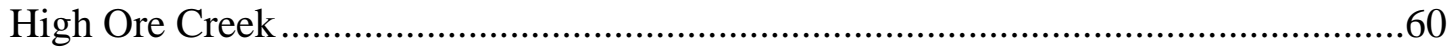

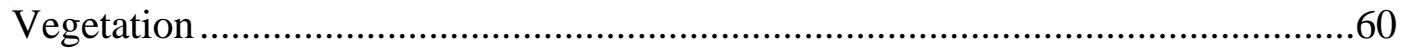

Soluble Metals and Arsenic ..............................................................................61 
TABLE OF CONTENTS CONTINUED

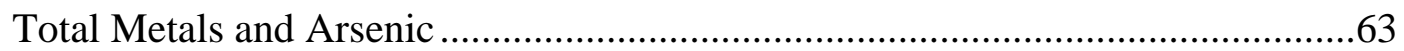

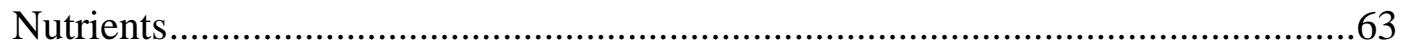

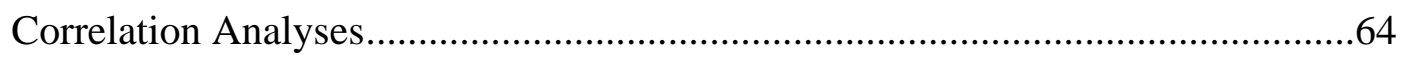

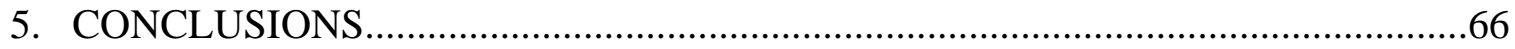

Vegetation Attributes and Soil Chemistry ………………........................................67

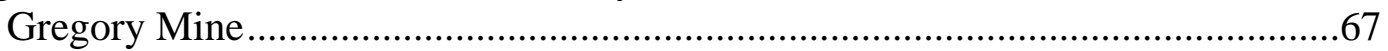

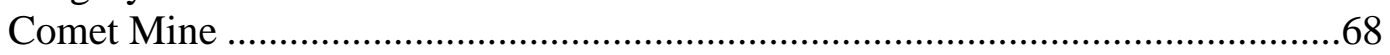

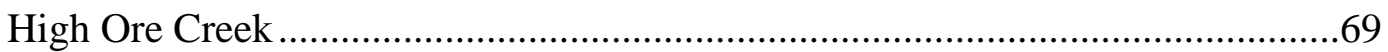

Established Vegetation....................................................................................70

Monitoring Reclamation Effectiveness...................................................................71

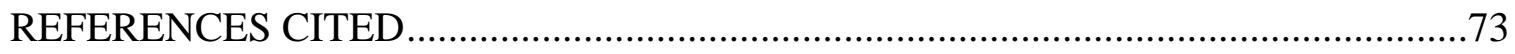

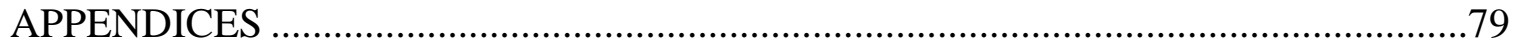

APPENDIX A: Canopy Cover and Biomass Production Data.......................................80

APPENDIX B: Species Lists for All Sites ............................................................127

APPENDIX C: Soil Chemistry Data .....................................................................134

APPENDIX D: Statistical Analyses Output .........................................................154 


\section{LIST OF TABLES}

Table

1. General Seed Mix Used at the Gregory Mine .7

2. Wetland Seed Mix Used at the Gregory Mine................................................

3. Streambank and Floodplain Seed Mix Used at the Comet Mine...........................9

4. Non-Streambank Seed Mix Used at the Comet Mine............................................9

5. Upper Streambank Seed Mix Used at High Ore Creek .....................................11

6. Riparian Seed Mix Used at High Ore Creek....................................................11

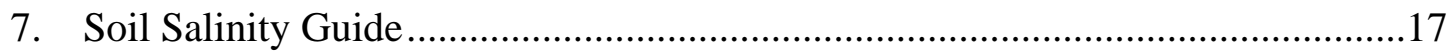

8. Effects of $\mathrm{pH}$ on the Availability of Trace Elements in Soil .............................19

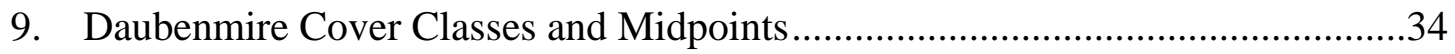

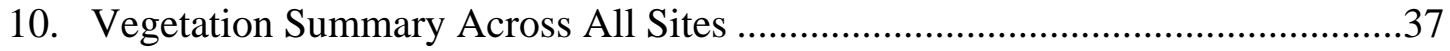

11. Summary of Soil Trace Elements Evaluated for this Study ..............................38

12. Summary of Soil $\mathrm{pH}$ and Metal Levels in Surface Soil Samples from the Gregory Mine, the Comet Mine, and High Ore Creek.

13. Summary of Average Soil Nutrient (mg kg-1) and Organic Matter (\%) Concentrations at All Sites.

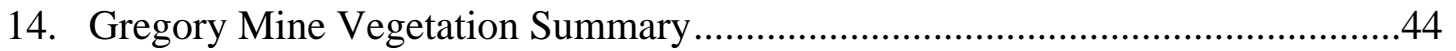

15. Species Located in Sample Areas at the Gregory Mine ...................................45

16. Soil $\mathrm{pH}$ (standard units) and Soluble Metals and Arsenic (mg L ${ }^{-1}$ ) Levels at the Gregory Mine....

17. Total Metals and Arsenic (mg kg-1) in Surface Soil Samples from the Gregory Mine 


\section{LIST OF TABLES CONTINUED}

Table

18. Nutrient ( $\mathrm{mg} \mathrm{kg}^{-1}$ ) and Organic Matter (\%) Concentrations in Surface Soil Samples from the Gregory Mine.

19. Comet Mine Vegetation Summary .52

20. Species Located in Sample Areas at the Comet Mine

21. Total Metal and As ( $\mathrm{mg} \mathrm{kg}^{-1}$ ) in Surface soil Samples from the Comet Mine. .54

22. Nutrient ( $\mathrm{mg} \mathrm{kg}^{-1}$ ) and Organic Matter (\%) Concentrations in Surface Soil Samples from the Comet Mine....

23. High Ore Creek Vegetation Summary

24. Species Located in Sample Ares at High Ore Creek

25. Soil pH (standard units) and Soluble Metal and As (mg L ${ }^{-1}$ )

Levels in Surface Soil Samples from High Ore Creek

26. Total Metal and As ( $\mathrm{mg} \mathrm{kg}^{-1}$ ) Levels in Surface Soil Samples from High Ore Creek

27. Nutrient (mg kg-) and Organic Matter (\%) Concentrations in Surface Soil Samples from High Ore Creek.

28. Field Canopy Cover Data, Total Percent Cover by Species and Sample Area, Standard Deviation, and Species Frequency from the Gregory Mine

29. Production Data from the Gregory Mine

30. Field Canopy Cover Data, Total Percent Cover by Species and Sample Area, Standard Deviation, and Species Frequency from the Comet Mine

31. Production Data from the Comet Mine

32. Field Canopy Cover Data, Total Percent Cover by Species and Sample Area, Standard Deviation and Species Frequency from High Ore Creek 


\section{LIST OF TABLES CONTINUED}

Table

33. Production Data from High Ore Creek .........................................................125

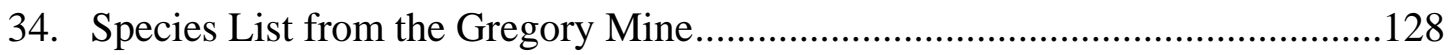

35. Species List from the Comet Mine …......................................................130

36. Species List from High Ore Creek.............................................................132

37. Soil Nutrients Data from Topsoil Samples

Collected at the Gregory Mine................................................................135

38. Soluble Metals and As Data from Topsoil Samples Collected at the Gregory Mine

39. Total Metals and As Data from Topsoil Samples

Collected at the Gregory Mine...

40. Soil Nutrients Data from Topsoil Samples Collected at the Comet Mine

41. Soluble Metals and As Data from a Subset of Topsoil Samples

Collected at the Comet Mine

42. Total Metals and As Data from Topsoil Samples

Collected at the Comet Mine

43. Nutrients Data from Topsoil Samples Collected at High Ore Creek.

44. Soluble Metals and As Data from Topsoil Samples

Collected at High Ore Creek.

45. Total Metals and As Data from Topsoil Samples

Collected at High Ore Creek 


\section{LIST OF FIGURES}

Figure

1. Location Map for the Gregory Mine, the Comet Mine, High Ore Creek

2. Correlation Analysis of Percent Canopy Cover and the Sum of Total Metals and Arsenic Levels (As, Cu, Pb, Zn)from All Mine Sites

3. Correlation Analysis of Species Richness and the Sum of Total Metals and As Levels (As, $\mathrm{Cu}, \mathrm{Pb}, \mathrm{Zn}$ ) from all Mine Sites

4. Correlation Analysis of Percent Canopy Cover and Soil Potassium Concentration (A), and Correlation Analysis of Biomass Production and Soil Potassium Levels (B)

5. Correlation Analysis for Percent Canopy Cover and H-ion Concentration

(A), and Percent Canopy Cover and Total Lead (B) at the Gregory Mine.

6. Correlation Analysis of Percent Canopy Cover and Potassium Concentration from the Gregory Mine

7. Correlation Analysis of Percent Canopy Cover and the Sum of Total

Metals and As Levels (As, $\mathrm{Cu}, \mathrm{Pb}, \mathrm{Zn}$ ) from the Comet Mine.

8. Correlation Analysis for Canopy Cover and Phosphorous Concentration

(A), and Percent Canopy Cover and Potassium Concentration

(B), from the Comet Mine

9. Correlation Analysis of Biomass Production and Potassium Concentration

(A) and Biomass Production and Phosphorous Concentration

(B), from the Comet Mine 


\begin{abstract}
Montana has an estimated 6000 abandoned mine sites, many with associated waste rock and tailings materials contributing to the release of high levels of acidity, heavy metals, and other contaminants, creating a risk to human health and the environment. Many abandoned mine sites in Montana have been reclaimed, however, little post-reclamation monitoring has been performed, and the effectiveness of reclamation has not been quantified. The goal of this project was to quantify the effectiveness of reclamation at three sites in Jefferson County, Montana based on soil suitability for sustaining plant growth.

Vegetation and soil studies were executed using a stratified random sampling design. Vegetation measurements included canopy cover using Daubenmire cover classes, above ground biomass, and species richness/diversity. Co-located soil samples were excavated in increments to a depth of $60 \mathrm{~cm}$, and determinations of $\mathrm{pH}$, electrical conductivity, nutrients, soluble, and total metal levels were made.

Canopy cover estimates ranged from $0-120 \%$ and biomass production estimates ranged from $0-4583 \mathrm{~kg} \mathrm{ha}^{-1}$. Differences in species richness and diversity were observed between sample strata. The chemical properties of the soil varied greatly, with $\mathrm{pH}$ values ranging from 2.08 to 7.63 , and soluble metal values ranging from $<0.1$ to $1001 \mathrm{mg} \mathrm{l}^{-1}$ for $\mathrm{Zn}, .02$ to $20.81 \mathrm{mg} \mathrm{l}^{-1}$ for $\mathrm{Cu},<.01$ to $7.39 \mathrm{mg} \mathrm{l}^{-1}$ for $\mathrm{Cd},<.05$ to $12.26 \mathrm{mg} \mathrm{l}^{-1}$ for As, and $<.1$ to $7.6 \mathrm{mg} \mathrm{l}^{-1}$ for $\mathrm{Pb}$. Sum of total metal and arsenic (As, $\mathrm{Cu}, \mathrm{Pb}$, and $\mathrm{Zn}$ ) concentrations ranged from 133 to $81448 \mathrm{mg} \mathrm{kg}^{-1}$. Associations between vegetation and soil chemistry were determined using correlation. Significant correlations between vegetation attributes and soil chemistry were found.

These results indicate that reclamation at the selected sites was moderately effective in reducing human and environment risk of exposure to harmful contaminants. There are concerns with upward migration of contaminants, and the sustainability of plant communities at all sites within the study. Elevated levels of residual metals and arsenic, as well as low $\mathrm{pH}$ conditions may have a deleterious effect on the long-term stability of the reclamation at these sites.
\end{abstract}




\section{CHAPTER 1}

\section{INTRODUCTION}

\section{$\underline{\text { Statement of Problem }}$}

Historic hard-rock mining in Montana has left over 6000 abandoned or inactive mine sites, each with associated waste materials posing a threat to human health and the environment (Pioneer Technologies Inc., 1995). Environmental problems associated with these sites include soil and water contamination from heavy metals and other contaminants. By 1991, the Montana Department of State Lands/Abandoned Mine Reclamation Bureau (MDSL/AMRB) had concluded that the imminent danger to human life had been eliminated at most mine sites in Montana, however; limited progress had been made in reducing the effects of contamination to surface and ground waters (Pioneer Technologies, 1995). In 1993 and 1994, 331 abandoned mine sites considered to have the highest hazard potential were inventoried and ranked based on severity of environmental hazards. Fifty-five sites were removed from the list due to lack of environmental hazards (Pioneer Technologies, 1995). Many of the remaining sites had limited vegetation cover or were completely devoid of vegetation.

Reclamation of these sites began in the mid 1990's [several sites have been reclaimed in the past decade]; however little post reclamation monitoring has been performed. Reclamation effectiveness has not been determined at many sites due to the lack of quantitative data, consistent and regular monitoring, and funding. 


\section{$\underline{\text { Purpose of Research }}$}

Reclamation of abandoned metal mines is expensive and difficult. Therefore, it is important to understand the biological and chemical process occurring on reclaimed mine sites to ensure efficient and effective reclamation. Reclaimed mine sites are often characterized by large variations in vegetation cover, barren areas, low species diversity, and limited species composition. The goal of this project was to quantify the effectiveness of reclamation at three sites in Jefferson County, Montana, based on the soil suitability for sustaining plant growth. The primary objectives for this project included:

1. determination of whether variations in vegetation production and cover were related to soil chemistry;

2. identification of species that have colonized the reclaimed sites and make comparisons to the applied seed mix; and

3. determination of which removal method was most effective in an impacted riparian zone.

Addressing these objectives will improve our knowledge of the effectiveness of current removal and replacement reclamation strategies, as well as enhance our knowledge of plant performance on reclaimed soils and natural occurrence of metal tolerant plants. 


\section{$\underline{\text { Study Area Description }}$}

\section{$\underline{\text { Geology }}$}

The three sites chosen for this project are the Gregory Mine, the Comet Mine, and High Ore Creek. All are located in Jefferson County (Figure 1) and lie within the Boulder Batholith. The Boulder Batholith, located in southwest Montana, is a northeast trending intrusive complex of Late Cretaceous (approximately 68-78 m. y.) age, and runs from south of Butte to Helena (Tilling, 1973). Two distinct magma series formed the batholith and $75 \%$ of the batholith is quartz monzanite (Tilling, 1973 and 1974). The main ore body consists of lenses, veins, and replacement bodies of chalcopyrite, pyrite, arsenopyrite, sphalerite, and galena (Tetra-Tech, 2001). These mineralized veins were extensively mined in Montana beginning in the late 1860's and continuing through the present.

\section{$\underline{\text { Climate }}$}

Located on the eastern side of the continental divide, these sites have a modified continental climate. The closest weather stations to all three sites are in Boulder and Basin, Montana, where average temperature ranges of $26{ }^{\circ} \mathrm{C}$ to $7{ }^{\circ} \mathrm{C}$ in July, and $0{ }^{\circ} \mathrm{C}$ to $-12{ }^{\circ} \mathrm{C}$ in January have been recorded. The average precipitation in these areas is approximately $30-36 \mathrm{~cm} \mathrm{yr}^{-1}$, with significantly higher precipitation levels in the surrounding mountains (Tetra-Tech, 2001). The general range type for this area is a Silty Range Site, 15-19” (Ross and Hunter, 1976). 


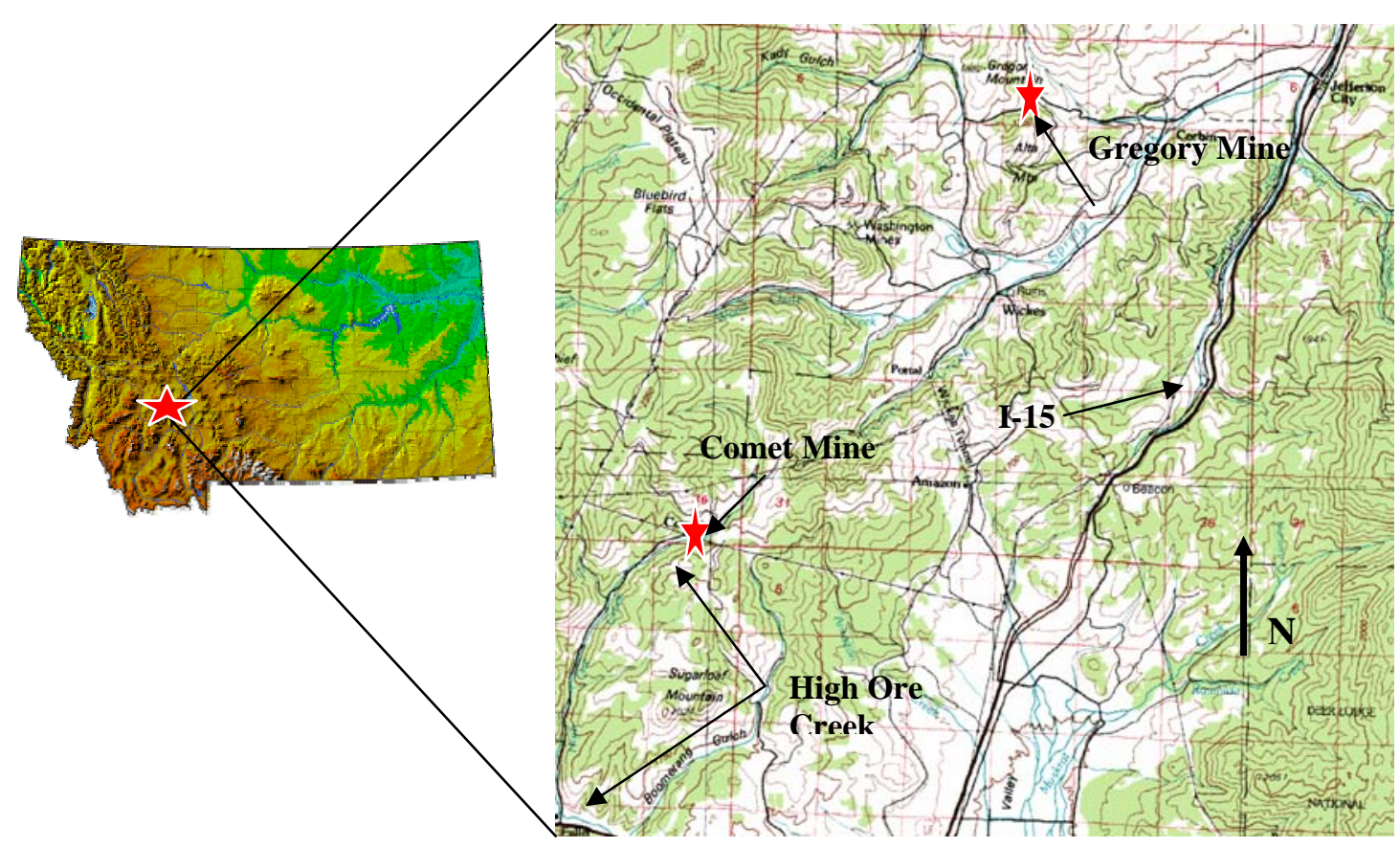

Figure 1. Location map for the Gregory Mine, the Comet Mine, and High Ore Creek.

\section{$\underline{\text { Reclamation Methods }}$}

Removal of waste materials and replacement with clean coversoil was the reclamation method used at the Gregory and Comet Mine sites, as well as some areas along High Ore Creek. Specific methods are detailed in the site descriptions. Limited post reclamation records are available, so much of the reclamation information was retrieved from the contract bids and expanded engineering evaluation and cost analysis reports that were compiled prior to reclamation. The actual reclamation methods may have differed from what is reported in the following sections. 


\section{$\underline{\text { Study Site Descriptions }}$}

\section{Gregory Mine}

The Gregory Mine is located in the Colorado Mining District, 9 miles southwest of Clancy, Montana, in Sections 4 and 5, Township 7 North, Range 4 West. The mine site lies within the Clancy Creek Drainage and has an elevation range of 1661 to 1707 meters above mean sea level. The general climax vegetation communities in surrounding areas are dominated by rough fescue, Idaho fescue, bluebunch wheatgrass, and Columbia needlegrass (Ross and Hunter, 1976).

Mining began at the Gregory Mine in 1864, and was one of the first silver-lead lodes mined in Montana. The site was mined sporadically until the 1950's, and is currently owned by Helena Silver Mines, Inc. (Tetra-Tech, 2001). The primary metals mined at this site included lead (Pb), zinc ( $\mathrm{Zn})$, gold (Au), and silver (Ag; Tetra-Tech, 2001).

An estimated 23,000 cubic meters $\left(\mathrm{m}^{3}\right)$ of waste rock and 10,000 $\mathrm{m}^{3}$ of tailings were located on the site and in the Gregory Creek and Clancy Creek drainages (Tetra-Tech, 2001).

Environmental concerns included high levels of $\mathrm{Pb}$, manganese (Mn), and arsenic (As) in soil and water samples, and copper $(\mathrm{Cu})$ and cadmium $(\mathrm{Cd})$ levels exceeding the Montana Acute Aquatic Life criteria (Pioneer Technologies, 1995). Total disturbance at this site covered approximately 2.5 hectares (ha), including 1 ha of wetlands (Tetra-Tech, 2001). The Gregory Mine ranked $57^{\text {th }}$ on the Montana Abandoned Hardrock Mine priorities list, and was reclaimed in the summer of 2002. 
Reclamation methods implemented at this site included standard removal and replacement methods as described by Tetra-Tech (2001). Two onsite repositories were constructed, and waste materials were placed into the repositories. The repositories were capped with a geosynthetic clay liner, and covered with $30 \mathrm{~cm}$ of subsoil and $15 \mathrm{~cm}$ of coversoil. Following completion of repository capping, Gregory Creek active stream channels and floodplains were reconstructed. The entire site was covered with $30 \mathrm{~cm}$ of subsoil and $15 \mathrm{~cm}$ of coversoil and re-graded. Following re-grading, the seedbed was prepared and the entire area was fertilized with nitrogen and phosphorous. The site was then seeded using two seed mixes; a general seed mix (Table 1), and a wetland seed mix (Table 2). The site was then covered in straw mulch and the surface was crimped.

Currently, the reclaimed Gregory Mine site is characterized by vegetation cover estimates ranging from 0 to $100+\%$ canopy cover. Red top (Agrostis alba) is the dominant riparian grass species and Yarrow (Achillea millefolium) is the dominant forb. Areas of sparse to no vegetation have white salts precipitated on the soil surface. Wetland areas with poor vegetation have iron staining and acid rock drainage present on the surface. 
Table 1. General seed mix used to reclaim the Gregory Mine (Tetra-Tech, 2001).

\begin{tabular}{|l|l|c|}
\hline \multicolumn{1}{|c|}{ Scientific Name } & \multicolumn{1}{c|}{ Common Name } & Lbs/ PLS/acre \\
\hline Agropyron spicatum & Bluebunch Wheatgrass & 6.0 \\
\hline Festuca scabrella & Rough Fescue & 4.0 \\
\hline Agropyron dasystachyum & Thickspike Wheatgrass & 3.0 \\
\hline Stipa viridula & Green Needlegrass & 1.5 \\
\hline Festuca idahoensis & Idaho Fescue & 1.5 \\
\hline Poa secunda & Sandberg Bluegrass & 16.5 \\
\hline Lupinus argenteus & Silvery Lupine & 0.5 \\
\hline Linum lewisii & Blue Flax & 0.5 \\
\hline Archillea millefolium & Western Yarrow & 0.5 \\
\hline Lolium multiflorum & Annual Ryegrass & 3.0 \\
\hline Medicago sativa & Alfalfa & 1.0 \\
\hline
\end{tabular}

Table 2. Wetland seed mix used to reclaim the Gregory Mine (Tetra-Tech, 2001).

\begin{tabular}{|l|l|l|l|}
\hline Scientific Name & Common Name & $\begin{array}{l}\text { Planting } \\
\text { Method }\end{array}$ & Wetland Status \\
\hline Carex nebraskenis & Nebraska Sedge & Seed & Obligate \\
\hline Glyceria elata & Fowl Mannagrass & Seed & Obligate \\
\hline Deschampsia caespitosa & Tufted Hairgrass & Seed & Facultative-Wet \\
\hline Elymus cinereus & Basin Wildrye & Seed & Facultative-Upland \\
\hline Alnus incana & Speckled Alder & Cuttings & Facultative-Wet \\
\hline Salix spp. & Willow & Cuttings & Facultative \\
\hline
\end{tabular}

\section{$\underline{\text { Comet Mine }}$}

The Comet Mine is located in the Basin/Cataract Mining District, 5 miles northwest of Boulder, Montana in Sections 35 and 36, Township 7 North, Range 5 West.

The elevation of the Comet Mine ranges from 1860 to 1950 meters above mean sea level (Brown et al., 2001). The general vegetation communities in surrounding areas are dominated by rough fescue, Idaho fescue, bluebunch wheatgrass, and Columbia needlegrass (Ross and Hunter, 1976). 
Mining began in 1880 at the Comet Mine, and is one of the oldest abandoned mine sites in the Basin/Cataract mining district. The site was mined intermittently until 1941, when the mine was closed (Browne et al., 2001). The primary metals mined at this site included $\mathrm{Au}, \mathrm{Ag}, \mathrm{Pb}, \mathrm{Zn}$, and $\mathrm{Cu}$ (Pioneer Technologies, 1995).

Environmental concerns associated with the waste rock and tailings at this site were releases of $\mathrm{As}, \mathrm{Cu}$, mercury $(\mathrm{Hg})$, antimony $(\mathrm{Sb}), \mathrm{Cd}, \mathrm{Mn}, \mathrm{Pb}$, and $\mathrm{Zn}$. Releases of $\mathrm{As}$, $\mathrm{Cd}, \mathrm{Cu}, \mathrm{Pb}, \mathrm{Mn}$, and $\mathrm{Zn}$ to the surface waters of High Ore Creek were found, with the Montana Acute Aquatic Life criteria exceeded for Zn, and the Montana Chronic Aquatic Life criteria exceeded for $\mathrm{Cu}$ and $\mathrm{Zn}$. Total disturbance at the Comet Mine covered approximately 14 ha, with an additional $6 \mathrm{~km}$ of disturbance along High Ore Creek. The Comet Mine ranked $10^{\text {th }}$ on the priorities list and reclamation began in 1997 (Pioneer Technologies Inc, 1996). Reclamation occurred in two phases: Phase 1 in 1997 and Phase 2 in 2001.

Waste materials were removed to approximate pre-mining contour, or to native soil. Tailings and waste rock were excavated and placed into the onsite Comet repository, or the off-site Bureau of Land Management repository. Waste materials placed in the Comet repository were capped with a Geosynthetic Clay Liner (GCL) and a $60 \mathrm{~cm}$ soil cap (Pioneer, 2003). The entire site was covered with $45 \mathrm{~cm}$ of borrow soil, and regraded to obtain uniform thickness (Olympus, 1999). Organic matter in the form of compost was incorporated to a depth of $30 \mathrm{~cm}$. The re-graded soil was fertilized with nitrogen, phosphorous, and potassium fertilizers, and the seedbed was prepared (Olympus, 1999; Pioneer, 2003). The site was then seeded using two seed mixes; a 
streambank and floodplain mix (Table 3) and a non-streambank mix (Table 4). After seeding, the entire site was covered in straw mulch and crimped (Pioneer, 2003).

Table 3. Streambank and floodplain seed mix used to reclaim the Comet Mine (Olympus, 1999).

\begin{tabular}{|l|l|c|}
\hline \multicolumn{1}{|c|}{ Scientific Name } & \multicolumn{1}{c|}{ Common Name } & lbs PLS/acre \\
\hline Agropyron spicatum & Bluebunch Wheatgrass & 8.0 \\
\hline Festuca scabrella & Rough Fescue & 12.0 \\
\hline Festuca idahoensis & Idaho Fescue & 8.0 \\
\hline Stipa viridula & Green Needlegrass & 6.0 \\
\hline Koleria cristata & Prairie Junegrass & 2.0 \\
\hline Poa secunda & Sandberg Bluegrass & 4.0 \\
\hline Lupinus perennis & Wild Lupine & 0.5 \\
\hline Linum lewisii & Blue Flax & 0.5 \\
\hline Archillea millefolium & Western Yarrow & 0.5 \\
\hline & Regreen & 15 \\
\hline
\end{tabular}

Table 4. Non-streambank seed mix used to reclaim the Comet Mine (Olympus, 1999).

\begin{tabular}{|l|l|c|}
\hline \multicolumn{1}{|c|}{ Scientific Name } & \multicolumn{1}{c|}{ Common Name } & lbs PLS/acre \\
\hline Agropyron smithii & Western Wheatgrass & 10.0 \\
\hline Agropyron Trachycaulum & Slender Wheatgrass & 12.0 \\
\hline Festuca idahoensis & Idaho Fescue & 4.0 \\
\hline Agropyron dasystachyum & Thickspike Wheatgrass & 6.0 \\
\hline Poa compressa & Canada Bluegrass & 4.0 \\
\hline Lupinus perennis & Wild Lupine & 0.5 \\
\hline Linum lewisii & Blue Flax & 0.5 \\
\hline Archillea millefolium & Western Yarrow & 0.5 \\
\hline & Regreen & 15 \\
\hline
\end{tabular}

The post-reclamation landscape at the Comet Mine is characterized by highly variable vegetation with canopy cover estimates ranging from o to $100+\%$. Red top (Agrostis $a l b a)$ is the dominant riparian grass at the Comet Mine. Areas of sparse vegetation have 
white salts precipitated on the soil surface. Large seeps are located on and below the waste repository, and acid rock drainage and iron staining are present.

\section{$\underline{\text { High Ore Creek }}$}

The High Ore Creek Drainage is located in the Basin/Cataract mining district, 5 miles northwest of Boulder, Montana in Sections 7, 2, 11, 14, 15, and 22, Township 6 North, Range 5 West, and Section 36, Township 7 North and Range 5 West. High Ore Creek runs $6 \mathrm{~km}$ from the Comet Mine to the confluence with the Boulder River and has an elevation range of 1555 meters above mean sea level at the Boulder River and 1920 meters above mean sea level at the Comet Repository (Pioneer, 2000). The general vegetation communities in surrounding areas are dominated by rough fescue, Idaho fescue, bluebunch wheatgrass, and Columbia needlegrass (Ross and Hunter, 1976).

Mining in the High Ore Creek Drainage began in 1880 with the opening of the Comet Mine. There are a total of 26 abandoned or inactive mines along the $6 \mathrm{~km}$ stretch of High Ore Creek. Major mining activities were completed in this drainage in 1941 (Pioneer, 2000).

The Comet Mine and Mill were the largest source of mining wastes into High Ore Creek, with an estimated 25,000 $\mathrm{m}^{3}$ of tailings in the floodplain (Pioneer, 1996). Metals of concern in the High Ore drainage included $\mathrm{Sb}, \mathrm{As}, \mathrm{Cd}, \mathrm{Cu}, \mathrm{Fe}, \mathrm{Pb}, \mathrm{Mn}, \mathrm{Au}$, and $\mathrm{Zn}$. Reclamation of High Ore Creek occurred within the $6 \mathrm{~km}$ stretch from the Comet Mine to the confluence with the Boulder River in the fall of 1999 and spring of 2000 (BLM, 2001). 
Reclamation methods at High Ore Creek included total, partial, and no removal of tailings materials, followed by placement of a coversoil and revegetation (BLM, 2001). Waste materials were transported to two repositories: the Comet Repository and an offsite BLM repository. Two seed mixes were used in the revegetation phase of reclamation; an upper streambank mix (Table 5) and a riparian mix (Table 6).

Table 5. Upper streambank seed mix used to reclaim High Ore Creek.

\begin{tabular}{|l|l|c|}
\hline \multicolumn{1}{|c|}{ Scientific Name } & \multicolumn{1}{c|}{ Common Name } & lbs PLS/acre \\
\hline Agropyron spicatum & Bluebunch Wheatgrass & 8 \\
\hline Festuca scabrella & Rough Fescue & 12 \\
\hline Festuca idahoensis & Idaho Fescue & 8 \\
\hline Achnatherum nelsonii & Columbia Needlegrass & 6 \\
\hline Koleria cristata & Prairie Junegrass & 2 \\
\hline Poa secunda & Sandberg Bluegrass & 4 \\
\hline Lupinus sericeus & Silky Lupine & 0.5 \\
\hline Eriogonum umbellatum & Sulfur Flower & 0.5 \\
\hline Archillea millefolium & Western Yarrow & 0.5 \\
\hline
\end{tabular}

Table 6. Riparian seed mix used to reclaim High Ore Creek.

\begin{tabular}{|l|l|c|}
\hline \multicolumn{1}{|c|}{ Scientific Name } & \multicolumn{1}{|c|}{ Common Name } & lbs PLS/acre \\
\hline Deschampsia caespitosa & Tufted Hairgrass & 2 \\
\hline Agropyron Trachycaulum & Slender Wheatgrass & 6 \\
\hline Festuca idahoensis & Idaho Fescue & 4 \\
\hline Calamagrostis spp. & Bluejoint Reedgrass & 3 \\
\hline Lupinus sericeus & Silky Lupine & 0.5 \\
\hline Eriogonum umbellatum & Sulfur Flower & 0.5 \\
\hline Archillea millefolium & Western Yarrow & 0.5 \\
\hline
\end{tabular}


Moderately variable vegetation cover and composition characterize the post reclamation landscape at High Ore Creek, with canopy cover estimates ranging from 30$80 \%$. Variations in species richness and diversity were also present, and no barren areas existed in sample areas. 


\section{CHAPTER 2}

\section{LITERATURE REVIEW}

\section{$\underline{\text { Revegetation and Reclamation Effectiveness }}$}

Establishing vegetation on reclaimed sites is the final phase of reclamation, and is perhaps the most important step in a reclamation project.

“...Essentially, the objectives of vegetation establishment are: long term stability of the land surface which ensures that there is no surface erosion by water or wind; reduction of leaching throughputs, lessening the amounts of potentially toxic elements released into local water courses and to groundwaters; development of a vegetated landscape or ecosystem in harmony with the surrounding environment; and with some positive value in an aesthetic, productivity, or nature conservation context (Johnson et al, 1994)."

Vegetation cover is effective in reducing erosion and reducing concentrations of heavy metals entering ground and surface waters (Tordoff et al., 2000), and is an important factor in the success of revegetation (Bleeker et al., 2002). There are three main approaches to revegetation; the ameliorative approach, the adaptive approach, and the agricultural approach (Johnson et al., 1994). Direct seeding with conventional species and fertilization is a common approach to revegetation of mine sites, due to low cost (Johnson et al., 1994). However, this approach is often unsuccessful in areas with high levels of metals residing in the root zone and low nutrient levels (Johnson et al., 1994). Brown et al. (2003) found the use of pioneer native species to be an effective approach to revegetation at the New World Mine in Montana, based on natural succession of plant species on adjacent disturbances of varying age. He suggests that these species have 
adapted to the acidic metalliferous conditions present, and seeds should be collected from the adjacent areas to ensure successful and sustainable revegetation. Seeding one or more $\mathrm{N}$ - fixing species may help overcome nitrogen deficiencies by nitrogen fixation from the atmosphere (Johnson et al., 1994; Bradshaw, 1997). Using tolerant plant species may decrease the cost of revegetation during reclamation of metalliferous sites (Smith and Bradshaw, 1979).

\section{$\underline{\text { Metal Tolerant Plants }}$}

Although waste materials may be removed during reclamation of mine sites, many trace elements such as $\mathrm{As}, \mathrm{Pb}, \mathrm{Zn}, \mathrm{Cu}$, etc., may still reside in the materials that lie within the rooting zone at levels that may restrict or prevent plant growth (Smith and Bradshaw, 1979). Plants growing in contaminated areas can develop metal tolerant genotypes called metallophytes or psuedometallophytes (Shu et al., 2005; Baker, 1987; Smith and Bradshaw, 1972). These plants have adapted to high metal levels and low nutrient levels, enabling them to grow on mine sites (Smith and Bradshaw, 1972). The mechanisms of metal tolerance are independent for each metal, although, they operate together (Wu and Antonovics, 1975). Metal tolerant plants may reduce the accumulation of metals in aboveground biomass, as well as delay phytotoxic responses (Bleeker et al., 2002). Commonly Agrostis and Festuca species are present on metalliferous spoils and soils (Smith and Bradshaw, 1979). Significant metal tolerance in multiple Agrostis species, specifically Agrostis tenuis, Agrostis capillaries, and Agrostis stolonifera, has been reported (Farago, 1981; Bleeker et al., 2002; Smith and Bradshaw, 1979; Wu and 
Antonovic, 1975; Meharg and Macnair, 1991; Surbrugg, 1982). Agrostis species are known colonizers of mine wastes in Europe, and have developed an As tolerance on Asrich mine wastes (Bleeker et al., 2002). Species of Agrostis have also exhibited tolerance to high levels of $\mathrm{Zn}, \mathrm{Cu}$ and $\mathrm{Cd}$, due to lack of accumulation of metals in the shoots and leaves. Zinc tolerance in plant species may be attributed to the lack of uptake by the roots, minimal transport to the shoots and leaves, and accumulation in the root zone (Farago, 1981). Shu et al. (2005) concluded that plants growing on $\mathrm{Pb} / \mathrm{Zn}$ mine tailings in China accumulated $\mathrm{Pb}, \mathrm{Cu}$, and $\mathrm{Zn}$ primarily in the roots, and $\mathrm{Cd}$ uniformly throughout the roots, shoots, and leaves. Bleeker et al. (2002) also found that minimal uptake of metals may contribute to the development of metal tolerance in Agrostis species. Festuca ovina and Festuca rubra have displayed tolerance to metalliferous spoils in Europe (Farago, 1981; Smith and Bradshaw, 1979). Deschampsia cespitosa has shown metal tolerance to phytotoxic levels of $\mathrm{Ni}, \mathrm{Cu}, \mathrm{Zn}$, and $\mathrm{Pb}$ (Frenckell-Insam and Hutchinson, 1993; Surbrugg, 1982), and arsenic (Meharg and Macnair, 1991).

\section{$\underline{\text { Species Richness and Diversity }}$}

Plant communities growing in in-situ reclaimed mine wastes have lower species diversity and a higher frequency of grass species than both uncontaminated reference areas and contaminated vegetated areas (Brown et al., 2005). Current methods of reclamation including removal of wastes and replacement with cover soil do not allow for natural soil development in the short term, and can therefore limit the number of establishing plant species, reducing species richness and overall land potential (Shu et al., 
2005). Bradshaw (1997) indicates that to achieve successful restoration, the soil must be remediated and vegetation must be re-established. Walli (1999) measured vegetation on reclaimed coal mine sites of differing ages $(1,7,17,30$, and 45 years). Plant species richness increased from the youngest site to the oldest; however, species richness was double the oldest site in an adjacent undisturbed area. Initial colonizers of the disturbed sites resided for a long time, with a delay of colonization from other species due to chemical constraints of the soil. Species diversity was also lowest at the youngest site and highest at the undisturbed site. He postulates that species richness may not be relevant in judging reclamation success, due to thick vegetation and rapid colonization of a few species. He suggests that in the early stages of reclamation, focus be on cover of a few species rather than on establishing high richness and diversity. It was concluded that regardless of the seed mix used, the species composition was determined by the viable seeds present in the coversoil. Brown et al. (2003) found that species richness on a reclaimed site was comparable (slightly higher) to undisturbed reference areas with low production and diversity. He also found that grass species frequency was higher than low and medium production reference areas, but slightly less than high production references. Forb frequency and richness was much lower than all reference areas. He recommended that grasses be the only life form used in a seed mix, and the added cost of adding forbs be avoided. He also concluded that forbs and sedges will naturally encroach revegatated areas, based on the forb richness in adjacent disturbed areas. 


\section{$\underline{\text { Limiting Factors for Plant Growth }}$}

Soil structure and function are degraded or lost during mining activities, which often results in soil toxicity, low nutrient availability, and poor soil texture. Soil structure and function, although only a part of an entire ecosystem, are analogous to the whole

ecosystem. If these factors are not remediated, vegetation re-establishment and restoring ecosystem function will be difficult or impossible (Bradshaw, 1997). Reclamation and revegetation of abandoned mine lands is often limited by physical and chemical properties existing in the soil, including (but not limited to) low $\mathrm{pH}$, high metal levels (including metal salts), low nutrient status, and poor or no soil structure.

\section{Electrical Conductivity}

Electrical conductivity (EC) is the measure of salinity in a soil. Soils to be used in reclamation typically have a target EC value of less than $4 \mathrm{dS}$. Salt sensitive plants may be inhibited at EC values less than $4 \mathrm{dS}$, while salt tolerant plants may not be affected by EC values greater than 8 dS (Munshower, 1994).

Table 7. Soil salinity guide (SCS, 1983).

\begin{tabular}{lcccc}
\hline Parameter & Non-Saline & Slightly Saline & Moderately Saline & Saline \\
\hline EC $(\mathrm{dS} / \mathrm{m})$ & $<4.0$ & $4.0-8.0$ & $8.0-16.0$ & $>16.0$ \\
\hline
\end{tabular}


Soil salinity reduces the availability of soil water to plants by increasing the soil-water potential, in particular the osmotic potential (Jurinak et al., 1987). This process stresses plants reducing or stunting growth. Both growth rate and size decrease as salinity increases (Jurinak et al., 1987). High soil salinity may also adversely influence the uptake of plant nutrients, especially nitrogen and potassium (Jurinak et al., 1987).

\section{$\underline{\text { Topsoil Depth }}$}

The depth of soil necessary for revegetation is a function of the physiochemical properties of the underlying materials, the desired vegetation community, and the quantity and quality of soil available (Bell, 2002). It is suggested by Bell (2002) that sulfidic wastes be buried by at least one meter of non-contaminated material before 10-20 cm of coversoil replacement. Barth and Martin (1984) found 101-152 cm of coversoil was needed for optimum plant production over acidic $(\mathrm{pH}=4.0)$ substrates. Approximately $40 \mathrm{~cm}$ of coversoil is needed for optimal plant production with neutral $(\mathrm{pH}=7.0)$ substrate (Barth and Martin, 1984).

\section{$\underline{\text { Soil } \mathrm{pH}}$}

Low soil $\mathrm{pH}$ resulting from the weathering and oxidation of sulfide minerals is the most common toxicity problem in mine soils (Bradshaw, 1997). Weathering and leaching of sulfide minerals will occur over time, but may take 30-50 years (Bradshaw, 1997). The most common sulfide mineral responsible for acid production in mine spoils is pyrite $\left(\mathrm{FeS}_{2}\right)$. When exposed to the atmosphere, pyritic materials are oxidized forming a series of soluble hydrous iron sulfates, which hydrolyze and increase acidity in 
surface and groundwaters. The overall oxidation reaction of pyrite to form sulfuric acid and iron hydroxide is given as (Caruccio et al., 1988):

$$
\mathrm{FeS}_{2}+15 / 4 \mathrm{O}_{2}+7 / 2 \mathrm{H}_{2} \mathrm{O}=2 \mathrm{SO}_{4}{ }^{2-}+4 \mathrm{H}^{+}+\mathrm{Fe}(\mathrm{OH})_{3}
$$

This reaction can be catalyzed in the presence of bacteria, specifically Thiobaccillus ferrooxidans, which thrive at $\mathrm{pH} 1.5-3.0$, and can make the reaction occur $10^{6}$ times faster (Caruccio et al., 1988; Johnson et al., 1994). Systems containing pyritic mine wastes can produce soils with a pH of less than 2.3. Montorroso et al. (1998) concluded that intense acidification $(\mathrm{pH}<4.0)$ due to the oxidation of sulfide minerals, seriously limits root penetration and plant growth. Low soil $\mathrm{pH}$ has several adverse effects including $\mathrm{Al}$ and Mn toxicity and nutrient deficiencies (Ye et al., 2002). Table 8 outlines trace element availability in terms of soil $\mathrm{pH}$.

Table 8. Effects of $\mathrm{pH}$ on the availability of trace elements in soil (Dickinson, 2002).

\begin{tabular}{ll}
\hline \multicolumn{1}{c}{ Soil $\mathrm{pH}$} & Highest Mobility and Availability \\
\hline Low $\mathrm{pH}(<5.5)$ & $\mathrm{Al}, \mathrm{Fe}, \mathrm{Mn}, \mathrm{Zn}, \mathrm{Cu}, \mathrm{Cd}, \mathrm{Pb}$ \\
Intermediate $\mathrm{pH}(5.5-7.0) \mathrm{NO}_{3}, \mathrm{PO}_{4}, \mathrm{~K}, \mathrm{Mg}, \mathrm{S}, \mathrm{B}, \mathrm{Cu}$ \\
High pH $(>7.0)$ & $\mathrm{Ca}, \mathrm{Mo}, \mathrm{As}, \mathrm{Se}$ \\
\hline
\end{tabular}

\section{Trace Elements in Root Zone}

Trace elements, specifically metals, are found in ore bodies, and released into the environment during the mining, milling, and smelting processes. These elements often 
create toxicity problems in soils, and contaminate surface and ground waters, creating exposure risks to humans, wildlife, and aquatic organisms. Once soils are contaminated with metals, metal levels are relatively static and will not be removed by natural processes (Bradshaw, 1997). Chemical properties of mine wastes are considered the greatest restraint to plant growth. The effects of heavy metals residing in the root zone restrict root development in plants, therefore inhibiting plant establishment (Tordoff et al., 2000). Phytotoxicity studies have shown root avoidance of soils with high metal levels, which may cause these plant systems to be more susceptible to drought, temperature stress, grazing impacts, and erosion (Kaputska, 2002). Certain heavy metals are essential trace elements at low concentrations, but can be toxic to pants at higher concentrations (Johnson et al., 1994). Trace elements considered essential for plant growth include $\mathrm{B}, \mathrm{Ca}, \mathrm{Co}, \mathrm{Cu}, \mathrm{Fe}, \mathrm{Mn}, \mathrm{Mo}, \mathrm{Si}$, Se, and $\mathrm{Zn}$ (Kabata-Pendias and Pendias, 1992). Other trace elements have proven to have stimulating effects on plant growth; however, their functions have not been identified (e.g. As, Se; Kabata-Pendias and Pendias, 1992). Kapustka (2002) found that phytotoxic effects including, inhibited height, shoot discoloration, and mortality, are related to a combination of metals (As, $\mathrm{Cu}$, and $\mathrm{Zn}$ ) and soil $\mathrm{pH}$.

Zinc. Zinc minerals are common in igneous parent materials and occur in sediments and sedimentary rocks. Zinc primarily occurs in sulfide minerals (ZnS), but can also substitute for $\mathrm{Mg}^{2+}$ in silicates (Kabata-Pendias, 2001). The solubilization of zinc minerals occurs during weathering, producing mobile $\mathrm{Zn}^{2+}$ and very soluble mineral compounds (Krzaklewski and Pietrzykowski, 2002; Kabata-Pendias 2001). At neutral 
$\mathrm{pH}$ values, $\mathrm{Zn}^{2+}$ readily forms complexes with soil organic matter and clay minerals, becoming relatively immobile and accumulates in the surface soil horizons (KabataPendias, 2001). $\mathrm{Zn}^{2+}$ is significantly more soluble at lower $\mathrm{pH}$ values.

Zinc is an essential element for plant growth; however, it can be phytotoxic at high levels, especially in acidic soils (Kabata-Pendias, 2001; Adriano, 2001). The phytotoxicity level of zinc in soils varies between $100-500 \mathrm{mg} \mathrm{kg}^{-1}$ depending on plant genotype and soil pH (Kabata-Pendias, 2001; CH2M Hill, 1987a,b; CDM Federal, 1997).

Cadmium. Cadmium $(\mathrm{Cd})$ occurs in magmatic and sedimentary rocks, is closely related to $\mathrm{Zn}$ in its geochemistry, and is highly soluble in acidic environments. Cd has a strong affinity for sulfur and its most common compound in nature is $\mathrm{CdS}$ (Adriano, 2001; Kabata-Pendias, 2001). Cd readily goes into solution during weathering and is known to occur as $\mathrm{Cd}^{2+}$ as well as in many other complexes. The mobility of $\mathrm{Cd}^{2+}$ is strongly dependant on soil $\mathrm{pH}$ and oxidation potential (Kabata-Pendias and Pendias, 1992).

Cadmium is not considered to be an essential element for plant metabolic processes, but it is absorbed by both root and leaf systems as well as accumulated in soil organisms (Kabata-Pendias, 2001). Soil $\mathrm{pH}$ is the controlling factor for bioavailability of $\mathrm{Cd}$ to plants (Adriano, 2001; Kabata-Pendias, 2001). Soil Cd levels of 3-100 mg kg-1 are considered phytotoxic, depending on the plant genotype and soil $\mathrm{pH}$ (Kabata-Pendias, 2001: CH2M Hill, 1987a,b; CDM Federal, 1997). 
Copper. Copper $(\mathrm{Cu})$ occurs in mafic and intermediate rocks, and forms several mineral complexes including sulfides (Kabata-Pendias, 2001). The most abundant mineral form of copper is chalcopyrite $\left(\mathrm{CuFeS}_{2}\right)$ (Adriano, 2001). These minerals are very soluble during the weathering process and release $\mathrm{Cu}$ ions, especially in acidic environments (Kabata-Pendias, 2001). $\mathrm{Cu}^{2+}$ is the most common form of mobile $\mathrm{Cu}$ in the surface environment; however $\mathrm{Cu}^{2+}$ can be held by inorganic and organic soil constituents by the process of adsorption, occlusion or coprecipitation, organic chelation and complexing, and microbial fixation (Kabata-Pendias, 2001). Cu contamination in soils is primarily driven by the high affinity of surface soils to accumulate $\mathrm{Cu}$ (KabataPendias, 2001).

$\mathrm{Cu}$ is an essential micronutrient for plant nutrition; however it is only required in small amounts $\left(5-20 \mathrm{mg} \mathrm{kg}^{-1}\right)$ (Adriano, 2001). Plants primary accumulate $\mathrm{Cu}$ in the roots, where it is held with minimal transport to the shoots and leaves (Kabata-Pendias, 2001). Phytotoxic levels of $\mathrm{Cu}$ vary from $100-1636 \mathrm{mg} \mathrm{kg}^{-1}$ depending on plant genotype and soil pH (Kabata-Pendias and Pendias, 1992; CH2M Hill, 1987 a,b; CDM Federal, 1997).

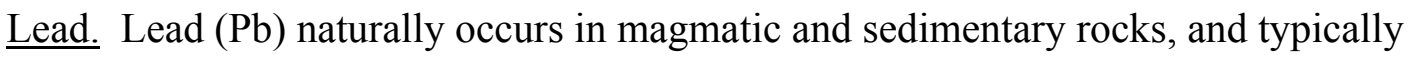
forms sulfide and carbonate minerals. The most common mineral forms of lead include galena $(\mathrm{PbS})$, cerrusite $\left(\mathrm{PbCO}_{3}\right)$, and anglesite $\left(\mathrm{PbSO}_{4}\right)$. Although the dominant form of lead in rocks is as a discrete mineral, $\mathrm{Pb}$ can replace $\mathrm{K}, \mathrm{Ba}, \mathrm{Sr}, \mathrm{Na}$ and $\mathrm{Ca}$ in the mineral lattice and on sorption sites (Adriano, 2001; Kabata-Pendias and Pendias, 1992). The 
solubility of lead is significantly lower than other trace metals in the environment, and is primarily controlled by soil $\mathrm{pH}$. Lead minerals are very insoluble, and therefore $\mathrm{Pb}$ is considered to be the least mobile of the heavy metals in natural environments, being 100 times less soluble than $\mathrm{Cd}$ in the $\mathrm{pH}$ range of 5-9 (Adriano, 2001; Kabata-Pendias, 2001). Lead has a strong affinity for organic mater and tends to accumulate in the surface layers of the soil profile (Adriano, 2001).

Lead is not considered to play an essential role in any metabolic process in plants. It is considered a major environmental pollutant and is phytotoxic to plants in the 100-1000 $\mathrm{mg} \mathrm{kg}^{-1}$ range (Kabata-Pendias and Pendias, 1992; CH2M Hill, 1987 a,b; CDM Federal, 1997). Low $\mathrm{Pb}$ concentrations in soils may inhibit some plant processes; however $\mathrm{Pb}$ poisoning has rarely been observed under field conditions (Kabata-Pendias, 2001 and Adriano, 2001). Lead is very toxic to fish, waterfowl, livestock, humans, and soil microbiota (Adriano, 2001).

Arsenic. Arsenic is a uniformly distributed element in the major rock types. As occurs naturally in most soils and is dependant on the parent material from which the soil formed. Soils formed from mineralized sulfide deposits are typically enriched in As (Adriano, 2001). There are over 200 As bearing minerals (Adriano, 2001; KabataPendias and Pendias, 1992). The two most common oxidation states of arsenic are As (III) and As (V). Arsenic (III) is much more toxic and more mobile than As (V) (Adriano, 2001). Arsenic compounds are readily soluble, but have limited mobility due to strong sorption by clays, hydroxides, and organic matter (Kabata-Pendias and Pendias, 1992). The bioavailability of As is controlled by the oxidation state of the soil, the 
amount of phosphorous (P) in the soil, soil pH, and soil organic matter (Adriano, 2001; Kabata-Pendias and Pendias, 1992). Arsenic and phosphorous have been found to react similarly in soils in terms of sorption capacities and bioavailability (Adriano, 2001).

Arsenic is a constituent of most plants, and root growth stimulation has been observed in some species, yet arsenic is not considered an essential element for plant metabolism (Adriano, 2001; Kabata-Pendias and Pendias, 1992). Phytotoxic levels of soil As have been recorded as 15-315 $\mathrm{mg} \mathrm{kg}^{-1}$ (Kabata-Pendias and Pendias, 1992; CH2MHill, 1987 a, b; CDM Federal, 1997). Total As is a relatively poor indicator of phytotoxicity. Multiple studies have shown higher correlation between plant growth and soluble As than total As (Adriano, 2001; Kabata-Pendias and Pendias, 1992). Symptoms of As phytotoxicity in plants include wilted leaves, violet coloration, root discoloration, and growth reduction (Adriano, 2001; Kabata-Pendias and Pendias, 1992). Inorganic As is a known carcinogen in humans and bioaccumulates in the food chain (Adriano, 2001).

\section{$\underline{\text { Upward Migration of Contaminants }}$}

Upward migration of soluble metals ions and salts may occur in reclaimed areas in the presence of a shallow water table (Tordoff et al., 2000). Monterroso et al. (1998) found that following coversoil application to metalliferous-acid producing soils, upward migration of acid sufficiently decreased the beneficial effects of soil replacement. In addition, plant growth in these areas was significantly limited. Soil replacement over sulfidic materials may initially provide a successful growth media for revegetation, but over time, the upward migration of contaminants will decrease the productivity of the applied soil (Bell, 2002). To avoid upward migration of contaminants, it is suggested 
that sulfidic wastes are placed out of the root zone, or an ameliorating layer is applied between the waste materials and coversoil. A capillary barrier may also be used to halt capillary action and reduce upward migration of contaminants (Bell, 2002). Kapustka (2002) found that both irrigation and evapotranspiration affected the metal levels in surface fill material. Over a thirteen week study, contaminant levels increased by $350 \%$ in the $10 \mathrm{~cm}$ of fill material closest to the buried tailings. It was concluded that mobility of contaminants from buried tailings pose a substantial risk to plants growing in the riparian zone (Kapustka, 2002).

\section{$\underline{\text { Nutrient Content }}$}

Nutrient uptake from soils is primarily from the soil solution. Nutrient uptake through the roots causes diffusion gradients of major nutrients $(\mathrm{N}, \mathrm{P}, \mathrm{K})$, increasing desorption of elements from clays and organic matter. Nutrients also enter the soil solution from decomposition of organic matter, soil minerals, atmospheric deposition, and symbiotic mycorrhizal associations (Dickinson, 2002; Munshower, 1994). Nutrient deficiencies are common in mined lands, and are often difficult to overcome by natural processes (Bradshaw, 1997). This is due to the lack of clay minerals and organic matter in the wastes, which provide cation exchange sites for the retention of nutrients. The absence of these materials often leads to rapid leaching of inorganic nutrients (Tordoff et al., 2000). Fertilizers can be used to overcome deficiencies of nitrogen, phosphorous, potassium, magnesium, and calcium (Bradshaw 1997). Waste products such as sewage sludge can be as effective as fertilizers in overcoming nutrient deficiencies (Bradshaw, 
1997). Fertilizing reclaimed land may not influence re-vegetation due to limiting factors such as low soil $\mathrm{pH}$ and high salinity (Dickinson, 2002).

Nitrogen. Nitrogen is the most important nutrient for plant re-establishment, and is required in the greatest amounts. Nitrate $\left(\mathrm{NO}_{3}{ }^{-}\right)$is the most common plant-available form of nitrogen (Munshower, 1994). Nitrate concentrations in soils vary as a function of season, plant growth rates, climate, and plant community (Munshower, 1994). Soil nitrate levels are typically very low during peak growing season because plants have taken up available nitrate. The average plant-available nitrogen level in rangeland soils is approximately $30 \mathrm{~kg} \mathrm{ha}^{-1}$ (Munshower, 1994). Nitrogen levels up to $1000 \mathrm{~kg} \mathrm{ha}^{-1}$ may be needed on reclaimed land to overcome the amount that would be provided by decomposing organic matter (Dickinson, 2002).

Nitrogen deficiencies can be problematic because nitrogen is absent from primary minerals (Bradshaw, 1997). Nitrogen deficiency produces chloritic plants and inhibits growth (Munshower, 1994). The establishment of nitrogen fixing plants and biological fixation can overcome nitrogen deficiencies. Nitrogen can then be transferred to the soil by the decomposition of plant materials, where it accumulates in the organic form (Bradshaw 1997).

Phosphorous. Phosphorous plays an important role in plant metabolism, and is usually present in soils as the phosphate ion $\left(\mathrm{PO}_{4}{ }^{2-}\right)$. Phosphorous deficiency symptoms include reduced growth in seedlings, reddish-purple discoloration, and death of leaf tips (Munshower, 1994). The majority of soil phosphorous is unavailable to plants due to its 
tendency to form complexes with soil organic mater, metals, and calcium (Munshower, 1994). Phosphate deficiencies may arise from the formation of non-soluble metalphosphate complexes (Tordoff et al., 2000). Plant available phosphorous levels increase with high levels of decomposing organic matter, due to the release of phosphorous during the decomposition of organic matter (Munshower, 1994). Phosphate availability is limited in acidic and alkaline soils (Dickinson, 2002). The presence of phosphate may reduce the toxicity of lead, zinc, and copper through precipitation and ion competition reactions (Johnson et al., 1994).

Potassium. Unlike $\mathrm{N}$ and $\mathrm{P}, \mathrm{K}$ is not bound to soil organic matter. Almost all soil potassium is derived from the mineral fraction of soil (Foth and Ellis, 1997). Potassium uptake is involved in photosynthesis, organic compound synthesis, and translocation of organic compounds. Potassium may be leached from plants during the growing season, due to lack of organic complexes (Foth and Ellis, 1997).

Potassium deficiency symptoms include yellowing of older leaves, necrosis, yellow mottling, curled leaf margins, early leaf fall, and eventual death (Foth and Ellis, 1997). Plants often remove $200 \mathrm{~kg} \mathrm{ha}^{-1}$ of potassium from the soil per growing season. Average soil potassium concentrations have been reported as 0.2\%-5\% (Dickenson, 2002; Munshower, 1994). Potassium uptake from plant roots is related to the concentration gradient between soil and root, rate of $\mathrm{K}$ diffusion through soil to root surfaces, and root surface area (Foth and Ellis, 1997). Soil moisture is the driving factor for potassium uptake, and as soil dries, uptake becomes increasingly difficult (Foth and Ellis, 1997). 
Organic Matter Content. Organic matter is a measure of the soil carbon content and is typically defined in two parts; recognizable organic matter (wood chips, mulch, straw, etc.), and humus (Munshower, 1994). Soil organic matter increases water holding capacity of the soil, soil porosity, infiltration, and cation exchange capacity (CEC) (Munshower, 1994; Dickenson, 2002). Soil organic matter also provides a source of nitrogen and other nutrients and impairs the mobility of heavy metals and contaminants in the soil (Farago, 1981; Bleeker et al., 2002; Monterroso et al., 1998; Brown et al., 2005; Munshower, 1994; Dickinson, 2002). Organic matter levels in Northern Great Plains soils range from 1-5\% (Munshower, 1994).

Mine waste materials and contaminated soils are often deficient in organic matter and humus (Farago, 1981). Metal ions and metalloids may sorb to organic matter particles, decreasing uptake of these contaminants by plants (Farago, 1981 and Bleeker et al., 2002). Metals will readily form stable complexes with both humic and fulvic fractions of organic acids in soil, depending on soil pH (Kabata-Pendias and Pendias, 1992). High soil metal levels and low soil $\mathrm{pH}$ inhibit organic matter decomposition, limiting nutrient availability (Dickinson, 2002; Ye et al., 2002).

\section{$\underline{\text { Water Availability }}$}

Soil water holding capacity and water availability are vital to successful re-vegetation on disturbed lands (Bell, 2002). Reclaimed soil texture and sufficient depth of rooting medium are two important factors in ensuring plants have adequate available water in a revegetation project (Bell, 2002). Cover soil with sandy or coarse textures often have 
poor water holding capacity. This may be overcome by adding organic matter in the form of manure or sewage sludge, or mixing the soil with fine-grained materials such as fly-ash (Bell, 2002). Soil water is important for microbial activity, gas exchange, and soil chemical reactions (Khan, 2002). 


\section{CHAPTER 3}

\section{METHODS AND MATERIALS}

Field studies for this project occurred at three sites; the Gregory Mine, the Comet Mine, and High Ore Creek. Soil and vegetation samples were collected during the July and August of 2005 at eighteen sites at both the Gregory and Comet Mines, and at six sites along the $6 \mathrm{~km}$ stretch of High Ore Creek from the Comet Mine to the confluence with the Boulder River.

\section{$\underline{\text { Sample Area Selection }}$}

\section{$\underline{\text { Gregory and Comet Mines }}$}

Sample areas were selected in the riparian zone of the Comet and Gregory sites. Two soil moisture regimes exist in the riparian zone: sub-irrigated (SB) (1-2yr floodplain) and overflow (OV) (10yr floodplain). The sub-irrigated and overflow areas were identified by determining proximity to surface water, and by digging exploratory holes to discover the depth to ground water. Vegetation cover was the criterion used to delineate sample areas. Vegetation criterion were the following:

- $\quad$ Poor (0-25\% vegetation cover);

- Moderate (26-75\% vegetation cover); and

- Good (76-100+\% vegetation cover). 
Three sample areas within each vegetation class and within both moisture regimes were identified at both the Gregory and Comet Mines. This created a total of eighteen sample areas at each mine site. Soil and vegetation samples were collected and measurements were made at each sample area.

\section{High Ore Creek}

Sample areas at High Ore Creek were along the creek in the riparian zone. Sample areas were based on two of the reclamation methods used during the reconstruction of High Ore Creek:

- No removal: tailings were left in place due to historic structures, trees, or relatively good vegetative cover;

- Partial/Total Removal: All or some of the waste materials were removed, and cover soil from a borrow area was placed on the surface.

Three sample areas within each reclamation method were selected along High Ore Creek. Exploratory soil pits were dug to identify the removal type at each location. Soil and vegetation samples were collected and measurements were made at each sample area.

\section{Sampling Design and Analysis}

Three soils pits, ten canopy cover frames, and ten aboveground biomass production

frames were sampled at each area. A species list was compiled for each site, and included a list of species present in sample areas as well as species present on the whole site. 


\section{$\underline{\text { Soil Sample Collection }}$}

Soils were collected in three randomly located pits within each sample area. These pits were excavated using a sharpshooter and standard shovel to $60 \mathrm{~cm}$ in overflow sample areas, and to $46 \mathrm{~cm}$ in sub-irrigated areas. Ground water was typically encountered within $30 \mathrm{~cm}$ in soil pits developed in sub-irrigated areas. Sub-samples of soils were collected based on visual or textural differences in the soil profile. Samples were collected using stainless steel shovels and placed into labeled plastic bags. Wet decontamination of sampling equipment was performed and a clean shovel was used for each sample. Wet decontamination included the following steps: 1) dry decontamination using a wire brush to remove excess soil from the shovels, 2) soapy wash consisting of 1 tablespoon of Alconox soap mixed with one gallon of deionized water 3) deionized water

rinse, and 4) deionized water spray. Field quality control was performed at a rate of 5\% (one set of QC samples for every 20 natural soil samples), and included field duplicates (split field sample), cross-contamination blanks $\left(\mathrm{SiO}_{2}\right.$ that has been in contact with a shovel following decontamination), and field blanks (pure $\mathrm{SiO}_{2}$ ).

\section{$\underline{\text { Soil Sample Preparation }}$}

Soil samples were transported to the Reclamation Research Unit (RRU) laboratory. Soils were air dried, de-aggregated with a mortar and pestle, and passed through a $2 \mathrm{~mm}$ sieve. Rock fragments larger than $2 \mathrm{~mm}$ were discarded. Composite samples were formed from soils within sample areas, based on similarities in physical properties and field description. 


\section{$\underline{\text { Soil Analytical Procedures }}$}

\section{Acidity and Electrical Conductivity Determination}

Saturated paste extracts were prepared in the RRU laboratory using standard techniques and analyzed for $\mathrm{pH}$ and $\mathrm{EC}$. Soil solution $\mathrm{pH}$ analysis was performed using USDA Handbook 60, Method 3a, 21c methods (U.S. Salinity Lab, 1969). Initial and end of the day $\mathrm{pH}$ meter calibrations were performed using $\mathrm{pH} 4.01,7.00$, and 10.00 standard buffer solutions. Continuing calibration of the $\mathrm{pH}$ meter was performed at a rate of $5 \%$ using the same standard solutions. Electrical conductivity was performed using USDA Handbook 60, Method 3a, 4b methods. Initial and end of day EC meter calibrations were performed using $447 \mu \mathrm{S}, 1500 \mu \mathrm{S}, 2764 \mu \mathrm{S}$, and $8974 \mu \mathrm{S}$ standard solutions. Continuing calibration of the EC meter was performed at a rate of 5\% using the same standard solutions. All measurements and solution temperatures were recorded. The saturated soil paste solutions and additional volumes of the prepared soils were sent to the MSU Soil and Water Analytical Laboratory (SWAL) for determination of total and soluble metals, nitrogen $(\mathrm{N})$, phosphorous $(\mathrm{P})$, potassium $(\mathrm{K})$, and organic matter $(\mathrm{OM})$ levels.

\section{$\underline{\text { Nutrient Analysis }}$}

Dry soils were sent to the MSU soils testing laboratory for N, P, K, and OM analysis. Nitrogen analysis $\left(\mathrm{NO}_{3}-\mathrm{N}\right)$ was performed using Method $4500 \mathrm{~F}, \mathrm{H}$ (APHA, 1989). Potassium analysis was performed using Method 13-3.5 (ASA, 1982). Phosphorous was analyzed using the Bray-P method, Method 24-5.1 (ASA 1982). Total organic matter analysis was based on total organic carbon using Method 29-3.5.2 (ASA 1982). 


\section{$\underline{\text { Soluble Metals Analysis }}$}

Saturated paste solutions were analyzed for soluble $\mathrm{As}, \mathrm{Cd}, \mathrm{Cu}, \mathrm{Pb}$, and $\mathrm{Zn}$ using inductively coupled plasma (ICP) following standard EPA-CLP methods (SOW 787, U.S. EPA).

\section{$\underline{\text { Total Recoverable Metals Analysis }}$}

Additional volumes of dry soils were sent to the MSU Soil and Water Analytical Laboratory for total extractable metals digestion and analysis of $\mathrm{Cu}, \mathrm{As}, \mathrm{Pb}$, and $\mathrm{Zn}$. The soils were digested using nitric acid and hydrogen peroxide, and metal concentrations were determined by ICP following standard EPA-CLP method 3050 (SOW 787, U.S. EPA).

\section{$\underline{\text { Vegetation Sample Collection and Preparation }}$}

\section{Canopy Cover}

Canopy cover measurements were taken by species using Daubenmire (1959) cover classes (Table 9). Ten 20 x $50 \mathrm{~cm}$ frames $\left(0.1 \mathrm{~m}^{2}\right)$ were randomly located within each Table 9. Daubenmire (1959) cover classes and midpoints.

\begin{tabular}{|c|c|c|}
\hline Class & Coverage Range & Midpoint \\
\hline 1 & $0-5 \%$ & $2.5 \%$ \\
\hline 2 & $5-25 \%$ & $15 \%$ \\
\hline 3 & $25-50 \%$ & $37.5 \%$ \\
\hline 4 & $50-75 \%$ & $62.5 \%$ \\
\hline 5 & $75-95 \%$ & $85 \%$ \\
\hline 6 & $95-100 \%$ & $97.5 \%$ \\
\hline
\end{tabular}


sample area and cover was estimated and recorded. Live cover by species, litter, rock, and bare ground cover classes were recorded on BLM cover sheets. Mean cover by species, mean total live cover, and standard deviation were calculated for each sample area. Species richness and diversity were also calculated for each study site. Species diversity was calculated using the inverse Simpson's index $\left(D=1 / \Sigma p_{i}^{2}\right.$, where $p$ is the proportion of individuals in the ith species) for species located in sample areas.

\section{$\underline{\text { Above Ground Biomass }}$}

Aboveground biomass frames were co-located with cover frames, and clipped by life form. Life forms included: perennial grass, annual grass, forbs, and shrubs. Ten $25 \times 25$

$\mathrm{cm}$ frames $\left(0.0625 \mathrm{~m}^{2}\right)$ were clipped within each sample area. Clipped vegetation was placed in labeled paper bags to allow moisture to escape. After drying at $75^{\circ} \mathrm{C}$ for 48 hours, samples were weighed to the nearest 0.01 gram and total aboveground biomass production and standard deviations were calculated.

\section{Statistical Methods}

\section{$\underline{\text { ANOVA }}$}

One-way analysis of variance (ANOVA) and independent sample t-tests ( $\mathrm{R}$ version 2.0.1, Sigma Stat version 3.0) were used to determine statistical differences within and between sample strata in terms of soil and vegetation data. A conservative version of the F-max test for equal variances (Largest $\mathrm{SD} /$ smallest $\mathrm{SD}<2$ ) was used to determine equal variances in data sets. Data transformations were used to meet the normality and equal variances assumptions, where needed. Several data sets were unable to meet these 
assumptions using standard transformations, and data was analyzed using Kruskal-Wallis test based on ranks. Significant differences were based on P-values less than 0.05. ANOVA and non-parametric test output is located in Appendix D.

\section{$\underline{\text { Correlation }}$}

Correlation (Sigma Plot version 9.0, Sigma Stat version 3.0) was used to determine associations between vegetation and soil chemistry data. The Pearson Product Moment Correlation was used to determine significant association between soil and vegetation

parameters. Associations are reported with vegetation cover and biomass as a function of soil chemistry. The correlation coefficient (r) is given with the P-value for each test. Significant correlation was assigned to tests with $\mathrm{P}$ values less than 0.05 . 


\section{CHAPTER 4 \\ RESULTS AND DISCUSSION}

\section{$\underline{\text { Vegetation }}$}

The vegetation at all three mine waste sites was highly variable. The Gregory Mine had the greatest average canopy cover and biomass production, as well as the greatest species richness (Table 10). High Ore Creek had the greatest species diversity, probably due to older plant communities residing in no removal areas. The plant communities at the Comet and Gregory Mines are less than ten years old and have had less time to establish a diverse community. Vegetation data for all analyses are in Appendix A.

Table 10. Vegetation summary across all sites.

\begin{tabular}{|c|c|c|c|c|c|}
\hline \multirow[b]{2}{*}{ Site } & \multirow{2}{*}{$\begin{array}{l}\text { Mean Cover* } \\
(\%)\end{array}$} & \multirow{2}{*}{$\begin{array}{l}\text { Mean Production* } \\
\quad\left(\mathrm{kg} \mathrm{ha}^{-1}\right)\end{array}$} & \multicolumn{2}{|c|}{ Species Richness } & \multirow{2}{*}{$\begin{array}{l}\text { Species** } \\
\text { Diversity } \\
\text { (D) }\end{array}$} \\
\hline & & & $\begin{array}{l}\text { Entire } \\
\text { Site }\end{array}$ & $\begin{array}{l}\text { Sample } \\
\text { Areas }\end{array}$ & \\
\hline Gregory & 70.9 & 1652.9 & 60 & 37 & 4.70 \\
\hline Comet & 38.1 & 873.6 & 39 & 12 & 2.38 \\
\hline High Ore Creek & 66.6 & 1447.1 & 52 & 28 & 7.55 \\
\hline
\end{tabular}

* Cover and production are given as mean values for each site.

\section{$\underline{\text { Soil Chemistry }}$}

Soil chemistry was highly variable at all sites, and may be attributed to the characteristics of the original waste materials and the applied reclamation method. Tailings and waste rock materials that were present below the borrow soil will be 
discussed in the following sections. Soil pH, soluble metal levels, total metal levels, and soil nutrients play a role in soil productivity and vegetation re-establishment. Electrical conductivity may also affect plant re-establishment at elevated levels (EC>5mS); however, electrical conductivity values were within suitable levels in all samples collected at the Gregory Mine, the Comet Mine, and High Ore Creek, and will not be discussed further. Several soil samples revealed concentrations of total $\mathrm{As}, \mathrm{Cu}, \mathrm{Pb}$, and Zn that were one to three orders of magnitude greater than regional background levels, and likely phytotoxic, which may contribute to the high variability in vegetation cover and production. Depth of coversoil may also contribute to the high variation in vegetation. The depth of the imported cover material was variable within and among sites, varying from thick $(>30 \mathrm{~cm})$ to thin $(<5 \mathrm{~cm})$, and in some areas non-existent. Phytotoxic and regional background metal levels are given in Table 11, and site-specific metal levels are given in Table 12. The effects of metals residing in the root zone restrict root development in plants, therefore inhibiting plant establishment (Tordoff, 2000).

Table 11. Summary of soil trace elements evaluated for this study.

\begin{tabular}{llll}
\hline Trace Element & $\begin{array}{l}\text { Regional } \\
\text { Background Level } \\
\left(\mathrm{mg} \mathrm{kg}^{-1}\right)\end{array}$ & $\begin{array}{l}\text { Phytotoxicity* } \\
\left(\mathrm{mg} \mathrm{kg}^{-1}\right)\end{array}$ & $\begin{array}{l}\text { Plant Nutritional } \\
\text { Requirement* } \\
(\mathrm{Y} / \mathrm{N})\end{array}$ \\
\hline Arsenic & 9.3 & $15-315$ & $\mathrm{~N}$ \\
Cadmium & 0.9 & $3-100$ & $\mathrm{~N}$ \\
Copper & 22.4 & $100-1636$ & $\mathrm{Y}$ \\
Lead & 35.7 & $100-1000$ & $\mathrm{~N}$ \\
Zinc & 66.1 & $100-500$ & $\mathrm{Y}$ \\
\hline
\end{tabular}

* Data summarized from: Adriano, 2001; CDM Federal, 1997, CH2M Hill, 1987a,b; and Kabata-Pendias and Pendias, 1992;

** Data summarized from PTI, 1997. 
Table 12. Summary of soil pH and metal levels in surface soil samples from the Gregory Mine, the Comet Mine and High Ore Creek.

\begin{tabular}{|c|c|c|c|c|c|c|c|c|}
\hline \multirow[t]{2}{*}{ Site } & \multirow{2}{*}{$\begin{array}{l}\text { Mean } \\
\text { Soil pH } \\
\text { surfacet }\end{array}$} & \multirow{2}{*}{$\begin{array}{l}\text { Mean } \\
\text { Soil pH } \\
\text { lowert }\end{array}$} & \multirow{2}{*}{$\begin{array}{l}\text { Sum of Metals* } \\
\left(m g g^{-1}\right)\end{array}$} & \multicolumn{5}{|c|}{ Soluble Metals** $\left(\mathrm{mg} \mathrm{L}^{-1}\right)$} \\
\hline & & & & As & $C d$ & $\mathrm{Cu}$ & $P b$ & $Z n$ \\
\hline Gregory & 3.92 & 3.05 & $1817 \pm 1395$ & $1.2 \pm 2.7$ & $1.1 \pm 3.1$ & $0.4 \pm 1.2$ & $0.6 \pm 1.4$ & $62.4 \pm 176$ \\
\hline Comet $* * *$ & 6.41 & 6.28 & $16998 \pm 21837$ & $0.2 \pm 0.2$ & $1.1 \pm 1.9$ & $0.3 \pm 0.4$ & $0.3 \pm 0.4$ & $163 \pm 190$ \\
\hline High Ore Creek & 6.17 & 6.24 & $6447 \pm 7614$ & $0.3 \pm 0.4$ & $0.1 \pm 0.2$ & $.08 \pm .04$ & $0.3 \pm 0.1$ & $75.5 \pm 195$ \\
\hline
\end{tabular}

* Sum of total $\mathrm{As}, \mathrm{Cu}, \mathrm{Pb}$, and $\mathrm{Zn}$, given as means and standard deviations.

** Values given as means and standard deviations of soluble metals for all samples throughout the $0-60 \mathrm{~cm}$ soil profile.

*** Soluble metal levels from subset of 10 samples.

$\dagger$ Surface increment was typically $0-30 \mathrm{~cm}$ and lower increment was $30-60 \mathrm{~cm}$, though, there was some variation in these increments, and sample collection was delineated as a function of soil layers, not distinct numerical increments. 
The average soil $\mathrm{N}$ level at all sites was very low, most likely due to sampling during peak growing season (Table 13). Soil nitrogen concentrations are dynamic throughout the growing season, with the highest values occurring at the beginning of the season, and the lowest values occurring during peak growing season. This is due to the plant available nitrogen being assimilated in plant tissues. Nitrogen is returned to the soils as organic matter following senescence (Foth and Ellis, 1997). Phosphorous levels were very high at all sites and were probably not a limiting factor for plant growth at these concentrations. Elevated phosphorous levels (eg., $700 \mathrm{mg} \mathrm{kg}^{-1}$ ) may cause a calcium deficiency in soils, due to the formation of insoluble Ca-P minerals (Jones and Jacobsen, 2005); however, only a few soils at the Comet Mine had levels this high. Potassium levels are in the low to moderate range for all sites. The critical value for potassium is approximately $250 \mathrm{mg} \mathrm{kg}^{-1}$ (Korb et al., 2005). Organic matter levels were in the low to high range, and fell within the average range (1-5\%) for Northern Great Plains soils (Munshower, 1994). Soil chemistry data for all analyses is in Appendix C.

Table 13. Summary of average soil nutrient* $\left(\mathrm{mg} \mathrm{kg}^{-1}\right)$ and organic matter* (\%) concentrations at all sites.

\begin{tabular}{lcccc}
\hline Site & \multicolumn{4}{c}{ Macronutrient* } \\
\cline { 2 - 4 } & $\mathrm{N}-\mathrm{NO}_{3}$ & $\mathrm{P}$ & $\mathrm{K}$ & $\mathrm{OM}$ \\
\hline Gregory & $1.5 \pm 2.5$ & $40.9 \pm 15.4$ & $222 \pm 102$ & $5.2 \pm 2.1$ \\
Comet & $1.2 \pm 1.3$ & $238 \pm 219$ & $196 \pm 129$ & $5.1 \pm 3.2$ \\
High Ore Creek & $2.4 \pm 1.9$ & $163 \pm 167$ & $111 \pm 64$ & $3.7 \pm 1.4$ \\
\hline
\end{tabular}

* Soil nutrient and organic matter levels given as means and standard deviations. 


\section{$\underline{\text { Correlation Analyses }}$}

Correlation was used to determine associations between soil chemistry and vegetation data collected at all sites, in order to identify common trends among all three mine waste sites. Total metals and As, and nutrient data were used to assess these relationships. Soluble metals and As data were excluded from these analyses due to an incomplete data set from the Comet Mine. Relationships between vegetation response, soil $\mathrm{pH}$, and sum of total metal levels have been postulated by EPA (1999), PTI (1994), Neuman et al., (2002), and Kaputska (2002). Mine wastes typically contain a mixture of metals, and it is difficult to identify the effects of individual metal levels in terms of a phytotoxic response (Kaputska et al., 1995). Therefore, it is important to identify the level of association that vegetation attributes have with sum of total metal levels and soil $\mathrm{pH}$.

A significant negative correlation was determined between canopy cover and the sum of total metals and arsenic (As, $\mathrm{Cu}, \mathrm{Pb}$, and $\mathrm{Zn}$; Figure 2). A significant negative correlation was also determined between species richness and the sum of total metal and arsenic levels (Figure 3). Significant negative correlations were determined between canopy cover and total As ( $\mathrm{r}=-0.319, \mathrm{P}=0.039)$, $\mathrm{Cu}(\mathrm{r}=-0.428, \mathrm{P}=0.0129)$, and $\mathrm{Zn}(\mathrm{r}=-$ 0.400, $\mathrm{P}=.009$ ) levels. $\mathrm{Zn}$ had the highest degree of association with canopy cover, most likely because it consistently had the highest levels at all sites (Appendix C). Canopy cover and biomass production were positively correlated with K concentrations (Figure 4 A, B). However, when all data points were used, correlations were not found between vegetation cover or production and soil N, P, or OM levels. Results for individual mine sites are discussed in detail in the following sections. 


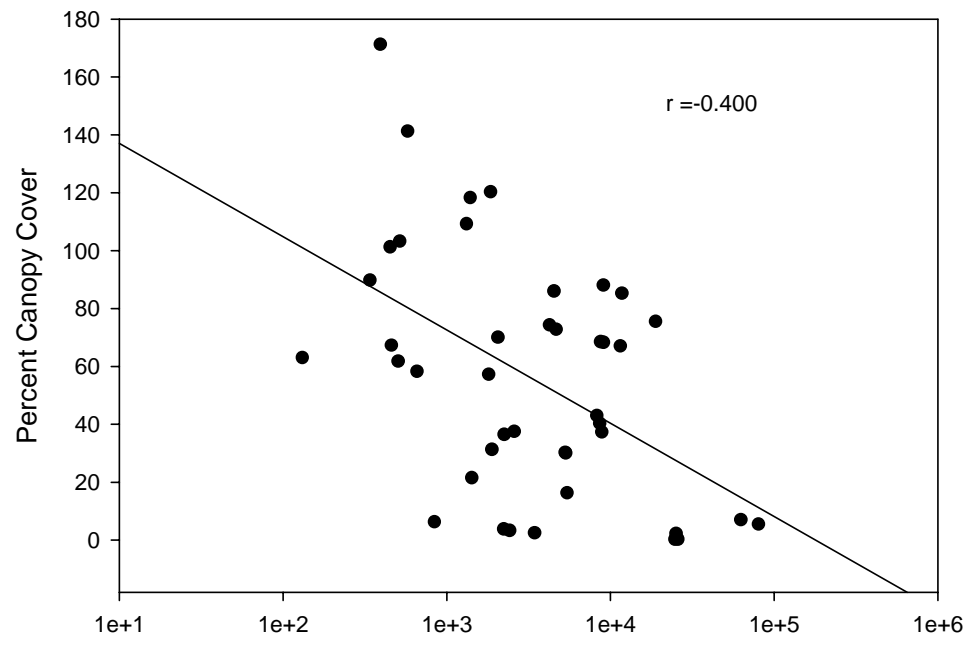

Sum of Total Metal and Arsenic (As, $\mathrm{Cu}, \mathrm{Pb}, \mathrm{Zn}$ ) Concentrations $\left(\mathrm{mg} \mathrm{kg}^{-1}\right)$

Figure 2. Correlation analysis of percent canopy cover and the sum of total metal and arsenic levels (As, $\mathrm{Cu}, \mathrm{Pb}, \mathrm{Zn})$ from all mine sites $(\mathrm{p}=0.009)$.

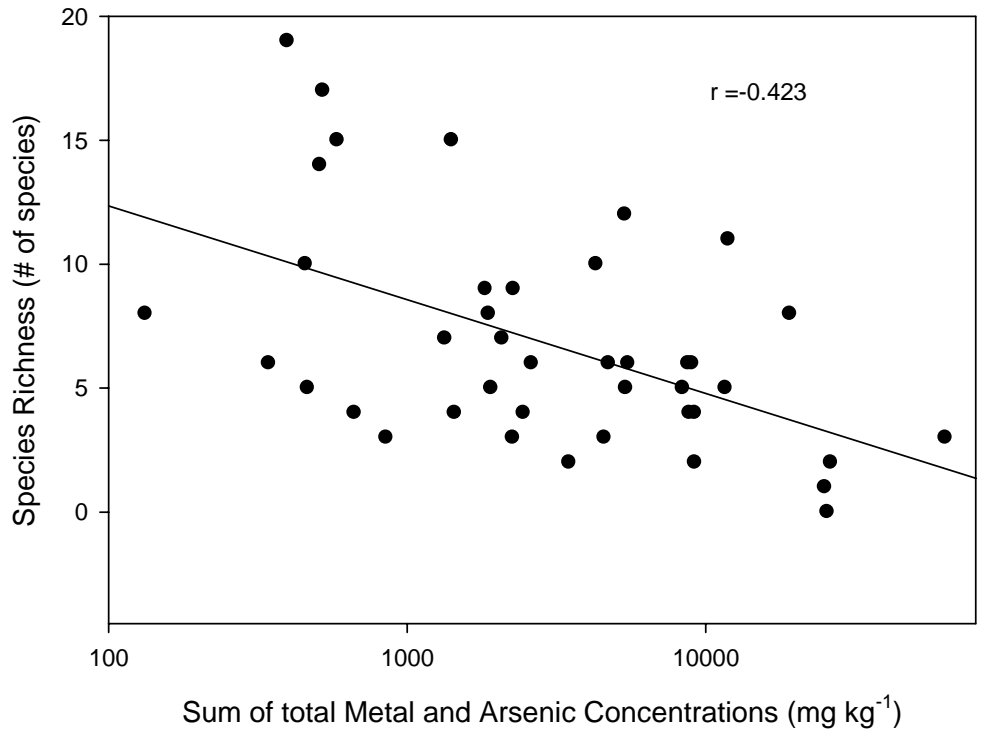

Figure 3. Correlation analysis for species richness and the sum of total metal and arsenic levels (As, $\mathrm{Cu}, \mathrm{Pb}, \mathrm{Zn})$ from all mine sites $(\mathrm{p}=0.005)$. 
(A)

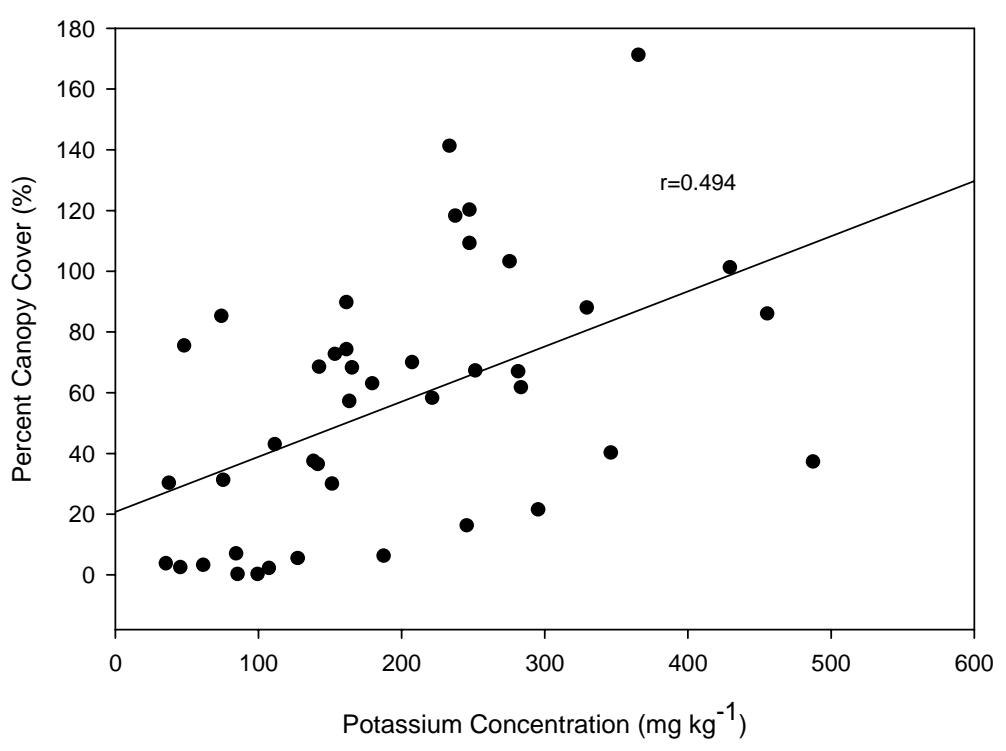

(B)

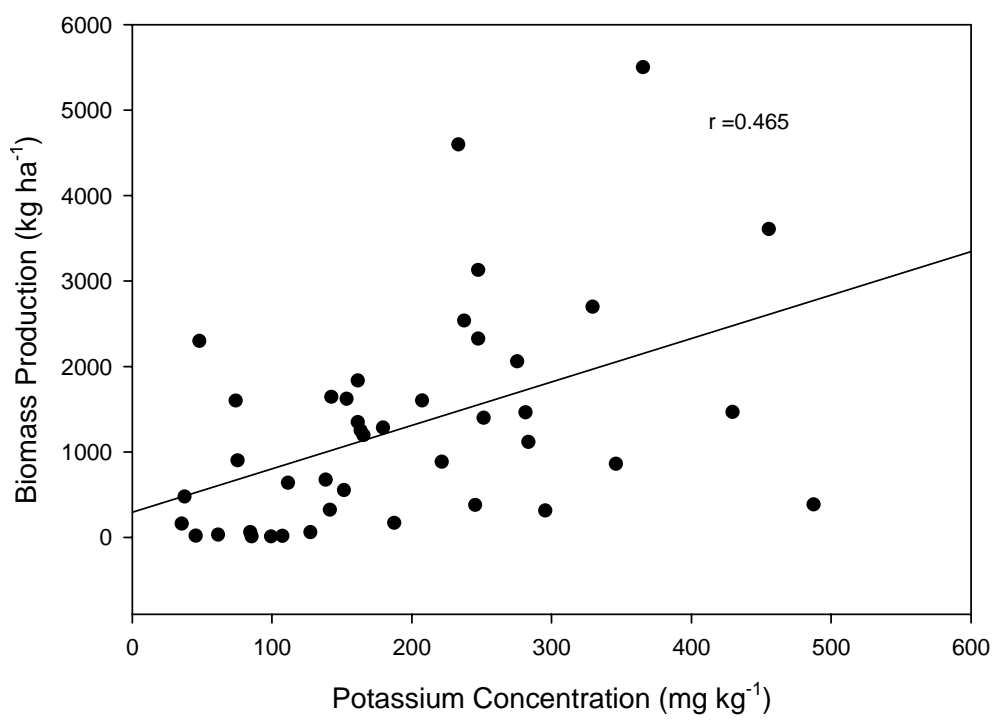

Figure 4. Correlation analysis of percent canopy cover and soil potassium concentration from all sites (A), and Correlation analysis of biomass production and soil potassium levels from all sites (B), $(p=0.0009$ and $p=0.002$, respectively). 


\section{Gregory Mine}

\section{$\underline{\text { Vegetation }}$}

The vegetation at the Gregory Mine was characterized by high variability in canopy cover and biomass production (Table 14). Canopy cover estimates ranged from 2-171\%.

Table 14. Gregory Mine vegetation summary.

\begin{tabular}{lccc}
\hline $\begin{array}{l}\text { Vegetation } \\
\text { Criteria }\end{array}$ & $\begin{array}{c}\text { Mean Cover* } \\
(\%)\end{array}$ & $\begin{array}{c}\text { Mean Production* } \\
\left(\mathrm{kg} \mathrm{ha}^{-1}\right)\end{array}$ & $\begin{array}{c}\text { Species Richness } \\
\text { in Sample Areas }\end{array}$ \\
\hline Good & $127 \pm 26 \mathrm{a}$ & $4202 \pm 1519 \mathrm{a}$ & 35 \\
Moderate & $73 \pm 16 \mathrm{~b}$ & $1498 \pm 491 \mathrm{~b}$ & 24 \\
Poor & $13 \pm 11 \mathrm{c}$ & $473 \pm 377 \mathrm{c}$ & 9 \\
\hline
\end{tabular}

* Cover and production values are given as means and standard deviations. a,b,c Means followed by the same letter are not significantly different $(\mathrm{P}>0.05)$.

Sample areas initially categorized as Good typically had over 100\% canopy cover. Poor areas had limited vegetation cover, typically in small patches, while Moderate and Good areas had relatively uniform vegetation throughout the sample area. Sample area above ground biomass ranged from 10-4583 $\mathrm{kg} \mathrm{ha}^{-1}$. Thirty-seven species were found within sample areas (Table 15), and the site species list contained 60 species (Appendix B). The three species that dominated this site were Agrostis alba, Festuca idahoensis, and Achillea millefolium, which contributed approximately $78 \%$ of the total cover in sample areas (Table 15). Two seed mixes containing 17 species were used during revegetation of the Gregory Mine. Poa secunda, Stipa viridula, Agropyron spicatum, Linum lewisii, and Lupinus sericeus were seeded species that did not occur in sample areas. F. 
idahoensis, Phleum pratense, Achillea millefolium, and Medicago sativa were the only seeded species to contribute greater than $0.5 \%$ of the cover in sample areas.

Table 15. Species** located in sample areas at the Gregory Mine.

\begin{tabular}{|c|c|c|c|c|c|}
\hline $\begin{array}{l}\text { Common } \\
\text { Name }\end{array}$ & Species Name & $\begin{array}{c}\text { Major Species* } \\
(Y / N)\end{array}$ & $\begin{array}{l}\text { Seeded } \\
(\mathrm{Y} / \mathrm{N})\end{array}$ & $\begin{array}{l}\text { Native } \\
(Y / N)\end{array}$ & $\begin{array}{c}\text { Relative Cover } \\
\text { (\%) }\end{array}$ \\
\hline Red Top & Agrostis alba & $\mathrm{Y}$ & $\mathrm{N}$ & Y & 33 \\
\hline Western Yarrow & Achillea millefolium & $\mathrm{Y}$ & $\mathrm{Y}$ & $\mathrm{Y}$ & 23 \\
\hline Idaho Fescue & Festuca idahoensis & $\mathrm{Y}$ & $\mathrm{Y}$ & $\mathrm{Y}$ & 22 \\
\hline Alfalfa & Medicago sativa & $\mathrm{Y}$ & $\mathrm{Y}$ & $\mathrm{N}$ & 3.0 \\
\hline Sedge & Carex sp. & $\mathrm{Y}$ & $\mathrm{N}$ & & 2.0 \\
\hline Timothy & Phleum pratense & $\mathrm{Y}$ & $\mathrm{N}$ & $\mathrm{N}$ & 1.8 \\
\hline Red Clover & Trifolium pratense & $\mathrm{Y}$ & $\mathrm{N}$ & $\mathrm{N}$ & 1.4 \\
\hline White Clover & Trifolium repens & $\mathrm{Y}$ & $\mathrm{N}$ & $\mathrm{N}$ & 1.0 \\
\hline Kentucky Bluegrass & Poa Pratensis & $\mathrm{Y}$ & $\mathrm{N}$ & $\mathrm{N}$ & 0.9 \\
\hline Baltic Rush & Juncus balticus & $\mathrm{Y}$ & $\mathrm{N}$ & $\mathrm{Y}$ & 0.8 \\
\hline $\begin{array}{l}\text { Smooth- } \\
\text { Scouringrush }\end{array}$ & Equisetum laevigatum & $\mathrm{Y}$ & $\mathrm{N}$ & $\mathrm{Y}$ & 0.8 \\
\hline Dwarf Fireweed & Epilobium latifolium & $\mathrm{Y}$ & $\mathrm{N}$ & $\mathrm{Y}$ & 0.7 \\
\hline Moss & & $\mathrm{Y}$ & & & 0.7 \\
\hline Slender Wheatgrass & Agropyron trachycaulum & $\mathrm{Y}$ & $\mathrm{N}$ & Y & 0.6 \\
\hline Rocky Mountain Iris & Iris missouriensis & $\mathrm{Y}$ & $\mathrm{N}$ & $\mathrm{Y}$ & 0.6 \\
\hline Tufted Hairgrass & Deschampsia caespitosa & $\mathrm{Y}$ & $\mathrm{Y}$ & $\mathrm{Y}$ & 0.5 \\
\hline Sulfur Cinquefoil & Potentilla recta & $\mathrm{Y}$ & $\mathrm{N}$ & $\mathrm{Y}$ & 0.5 \\
\hline $\begin{array}{l}\text { Thickspike- } \\
\text { Wheatgrass }\end{array}$ & Agropyron dasystachyum & $\mathrm{N}$ & $\mathrm{Y}$ & $\mathrm{Y}$ & 0.4 \\
\hline Nebraska Sedge & Carex nebrascensis & $\mathrm{N}$ & $\mathrm{Y}$ & $\mathrm{Y}$ & 0.3 \\
\hline Fowl Mannegrass & Glyceria striata & $\mathrm{N}$ & $\mathrm{Y}$ & $\mathrm{Y}$ & 0.3 \\
\hline Goldenrod & Solidago missouriensis & $\mathrm{N}$ & $\mathrm{N}$ & Y & 0.1 \\
\hline Tar Weed & Madia sativa & $\mathrm{N}$ & $\mathrm{N}$ & $\mathrm{Y}$ & 0.1 \\
\hline Strawberry & Fragaria vesca & $\mathrm{N}$ & $\mathrm{N}$ & $\mathrm{Y}$ & $<0.1$ \\
\hline Toad rush & Juncus bufonius & $\mathrm{N}$ & $\mathrm{N}$ & $\mathrm{Y}$ & $<0.1$ \\
\hline Ryegrass & Lolium multiflorum & $\mathrm{N}$ & $\mathrm{Y}$ & $\mathrm{Y}$ & $<0.1$ \\
\hline Purple Aster & Machaeranthera canescens & $\mathrm{N}$ & $\mathrm{N}$ & $\mathrm{Y}$ & $<0.1$ \\
\hline Woods Rose & Rosa woodsii & $\mathrm{N}$ & $\mathrm{N}$ & $\mathrm{Y}$ & $<0.1$ \\
\hline Tall Buttercup & Ranunculus acris & $\mathrm{N}$ & $\mathrm{N}$ & $\mathrm{N}$ & $<0.1$ \\
\hline Quaking Aspen & Populus tremuloides & $\mathrm{N}$ & $\mathrm{N}$ & $\mathrm{Y}$ & $<0.1$ \\
\hline Cudweed Sagewort & Artemisia ludoviciana & $\mathrm{N}$ & $\mathrm{N}$ & $\mathrm{Y}$ & $<0.1$ \\
\hline Switch Grass & Panicum virgatum & $\mathrm{N}$ & $\mathrm{N}$ & $\mathrm{Y}$ & $<0.1$ \\
\hline Broadleaf Plantain & Plantago major & $\mathrm{N}$ & $\mathrm{N}$ & $\mathrm{N}$ & $<0.1$ \\
\hline Rough Fescue & Festuca scabrella & $\mathrm{N}$ & $\mathrm{N}$ & $\mathrm{Y}$ & $<0.1$ \\
\hline Pussytoes & Antennaria spp. & $\mathrm{N}$ & $\mathrm{N}$ & $\mathrm{Y}$ & $<0.1$ \\
\hline Bull thistle & Cirsium vulgare & $\mathrm{N}$ & $\mathrm{N}$ & $\mathrm{N}$ & $<0.1$ \\
\hline \multicolumn{2}{|c|}{ Unidentified Forb \#1-4 } & $\mathrm{N}$ & & & $<0.1$ \\
\hline
\end{tabular}

* Major species contribute $>0.5 \%$ of the total cover within sample areas.

** Species data adapted Hitchcock et al., (1973). 
The species Agrostis alba was not seeded, but contributed 33\% of the total cover. This may be attributed to metal tolerance of Agrostis species (Bleeker, 2002 and Farago, 1981), and aggressive colonization in disturbed areas (Munshower,1998).

\section{$\underline{\text { Soluble Metals and Arsenic }}$}

Soil pH levels were determined for all soil samples collected at the Gregory Mine. The $\mathrm{pH}$ range for topsoils was 3.84-6.91, and $\mathrm{pH}$ ranged from 2.08-7.05 for subsoils. Average $\mathrm{pH}$ values for sample areas are displayed in Table 16. Water soluble soil metal and As concentrations were determined in topsoils from all sample areas, and average values are also presented in Table 16. Soil pH is a significant determining factor in the solubility of metals (Kabata-Pendias and Pendias, 1992). Poor sample areas had significantly higher soluble metal levels than Good and Moderate areas. Soluble Pb levels were below detection limits for Good and Moderate sample areas, most likely due

to limited solubility of lead in relation to other metals (Kabata-Pendias, 2001 and Adriano 2001). Soluble metal concentrations were greatest in Poor sample areas due to lower soil $\mathrm{pH}$ values.

\section{$\underline{\text { Total Arsenic and Metal Levels }}$}

Total metal and As levels were determined in topsoil samples in all sample areas. Mean concentrations and standard deviations are displayed in Table 17. One-way analysis of variance showed no significant difference $(\mathrm{P}>0.05)$ among sums of total metal levels between Good, Moderate, and Poor areas. This is due to the large variation in metal levels at the site and large standard deviations among sample areas. 
Table 16. Soil pH (standard units) and soluble soil metals and As levels at the Gregory Mine.

\begin{tabular}{|c|c|c|c|c|c|c|c|}
\hline \multirow{2}{*}{$\begin{array}{l}\text { Vegetation } \\
\text { Criteria }\end{array}$} & \multirow{2}{*}{$\begin{array}{l}\text { Soil pH } \\
\text { surface }^{* *}\end{array}$} & \multirow{2}{*}{$\begin{array}{l}\text { Soil pH } \\
\text { lower** }\end{array}$} & \multicolumn{5}{|c|}{$\operatorname{Metal}^{*}\left(m g L^{-1}\right)$} \\
\hline & & & As & $C d$ & $\mathrm{Cu}$ & $P b$ & $\mathrm{Zn}$ \\
\hline Good & $5.28 \mathrm{a}$ & 3.71 & $.13 \pm .11 \mathrm{a}$ & $.01 \pm .004 a$ & $.045 \pm .037 a$ & $<.1$ & $4.2 \pm 3.1 \mathrm{a}$ \\
\hline Moderate & $4.88 \mathrm{a}$ & 3.07 & $.21 \pm .21 \mathrm{ab}$ & $.02 \pm .01 \mathrm{a}$ & $.056 \pm .037 a$ & $<.1$ & $4.8 \pm 6.2 \mathrm{a}$ \\
\hline Poor & $3.49 \mathrm{~b}$ & 2.85 & $1.63 \pm 2.05 a$ & $1.5 \pm 2.6 \mathrm{a}$ & $1.5 \pm 1.6 b$ & $1.63 \pm 2.65$ & $217 \pm 355 b$ \\
\hline
\end{tabular}

* $\quad$ Metals data are presented as means and standard deviations.

** Surface increment was typically $0-30 \mathrm{~cm}$ and lower increment was $30-60 \mathrm{~cm}$, though, there was some variation in these increments, and sample collection was delineated as a function of soil layers, not distinct numerical increments.

a,b Means followed by the same letter are not significantly different $(\mathrm{P}>0.05)$. 
Table 17. Total metals* and arsenic $\left(\mathrm{mg} \mathrm{kg}^{-1}\right)$ in surface soil samples from the Gregory Mine.

\begin{tabular}{|c|c|c|c|c|c|}
\hline $\begin{array}{l}\text { Vegetation } \\
\text { Criteria }\end{array}$ & As & $C u^{* *}$ & $P b$ & $Z n$ & Sum of Metals*** \\
\hline Good & $172 \pm 179 \dagger$ & $80 \pm 46$ & $259 \pm 226$ & $540 \pm 323 \dagger$ & $1224 \pm 716 a$ \\
\hline Moderate & $1123 \pm 1240 \dagger$ & $100 \pm 98 \dagger$ & $701 \pm 653$ & $394 \pm 214 \dagger$ & $1867 \pm 2285 \mathrm{a}$ \\
\hline Poor & $813 \pm 519 \dagger$ & $115 \pm 40 \dagger$ & $1274 \pm 1094 \dagger$ & $636 \pm 629 \dagger$ & $2361 \pm 1068 \mathrm{a}$ \\
\hline
\end{tabular}

* Total metals displayed as means and standard deviations in topsoil samples within sample areas.

** Copper data from the overflow zone only.

***Sum of $\mathrm{As}, \mathrm{Cu}, \mathrm{Pb}$, and $\mathrm{Zn}$ from overflow zone only.

a Means followed by the same letter are not significantly different $(\mathrm{P}>0.05)$.

$\dagger$ Indicates possible phytotoxicity.

\section{Nutrients}

There are no significant differences in soil N, P, or OM levels among Good, Moderate, and Poor sample areas at the Gregory Mine (Table 18). Soil N levels were very low for all sample areas at the Gregory Mine. This was expected because samples were collected during peak growing season, when plants have taken up soil N. Soil P, K, and $\mathrm{OM}$ were all within reasonable levels for sustaining plant growth. Significant differences were found in K levels between Good and Poor sample areas (Figure 18), where levels were significantly lower in Poor areas compared to Good sample areas. Significant differences were not found in K levels between Good and Moderate and Moderate and Poor sample areas. 
Table 18. Nutrient $\left(\mathrm{mg} \mathrm{kg}^{-1}\right)$ and organic matter (\%) concentrations in surface soil samples from the Gregory Mine.

\begin{tabular}{lcccc}
\hline $\begin{array}{l}\text { Vegetation } \\
\text { Criteria }\end{array}$ & \multicolumn{4}{c}{ Macronutrient } \\
\cline { 2 - 4 } & $N$ & \multicolumn{1}{c}{$P$} & \multicolumn{1}{c}{ O } & \\
\cline { 2 - 5 } & & & & \\
Good & $2.7 \pm 3.8 \mathrm{a}$ & $35.3 \pm 9.3 \mathrm{a}$ & $294 \pm 83.4 \mathrm{a}$ & $6.6 \pm 1.9 \mathrm{a}$ \\
Moderate & $.77 \pm 1.0 \mathrm{a}$ & $37.4 \pm 17.5 \mathrm{a}$ & $225 \pm 56.3 \mathrm{ab}$ & $4.3 \pm 1.9 \mathrm{a}$ \\
Poor & $.95 \pm 1.7 \mathrm{a}$ & $50.1 \pm 16.2 \mathrm{a}$ & $148 \pm 110 \mathrm{~b}$ & $4.6 \pm 1.9 \mathrm{a}$ \\
\hline
\end{tabular}

a,b Means followed by the same letter are not significantly different $(\mathrm{p}>0.05)$.

\section{Correlation Analyses}

Correlation was used to determine the level of association between vegetation, soil $\mathrm{pH}$ (Figure 5, A), and soil metal levels, as well as between vegetation and soil nutrients. A significant negative correlation $(\mathrm{r}=-0.65, \mathrm{P}=0.004)$ was determined between percent canopy cover and soil $\mathrm{pH}$ (H-ion concentration). A significant negative correlation was not found between the sum of total metals and the percent canopy cover $(r=-0.41$, $\mathrm{P}=0.09$ ). A significant association was not found between soil $\mathrm{pH}$ and sum of total metals. Phytotoxic levels of $\mathrm{As}, \mathrm{Cu}, \mathrm{Pb}$, and $\mathrm{Zn}$ were observed in topsoil samples (Table 17). Although $\mathrm{Zn}$ and As levels lie within the phytotoxic range in all vegetation groups, no significant correlation exists between either metal level and percent canopy cover. Significant negative correlation was found between total $\mathrm{Pb}$ and percent canopy cover ( $\mathrm{r}$ $=-0.55, \mathrm{P}=0.02)($ Figure 5, B). 
(A)

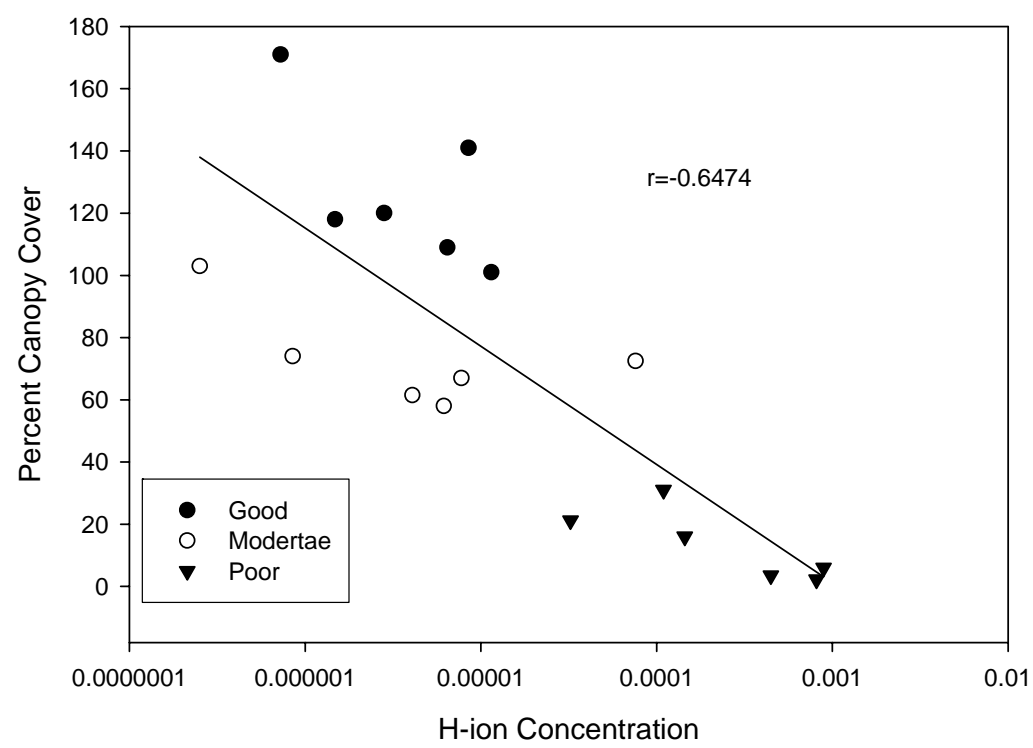

(B)

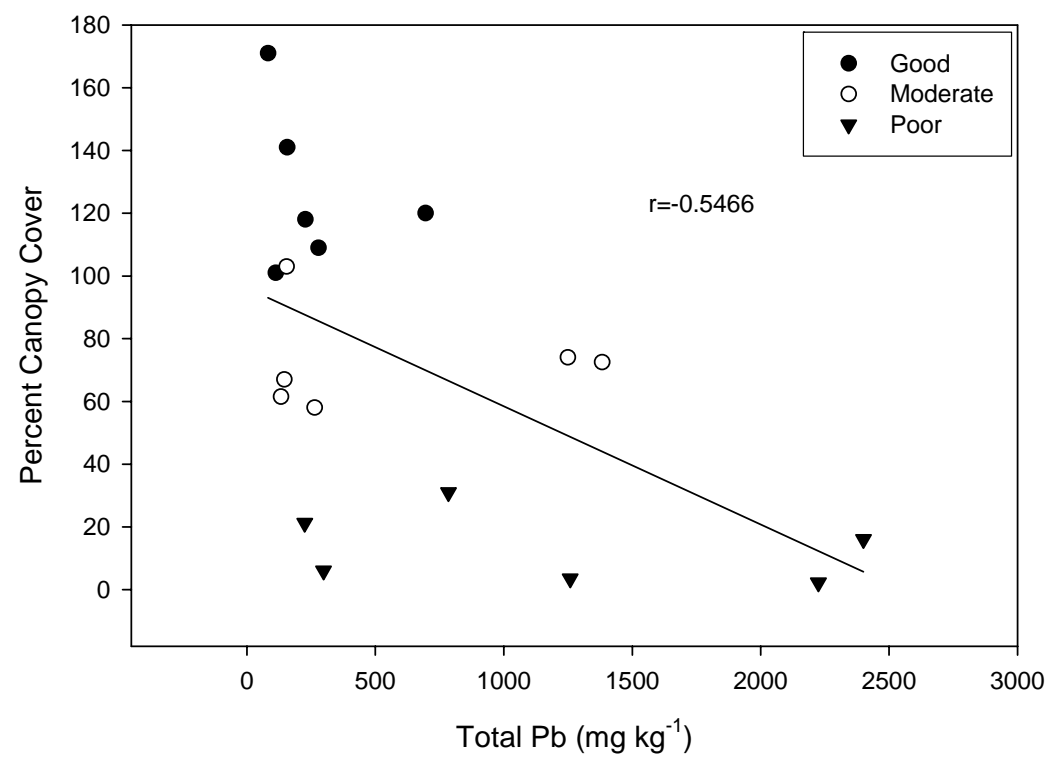

Figure 5. Correlation analysis for percent canopy cover and $\mathrm{H}$-ion concentration $(\mathrm{P}=0.004)(\mathrm{A})$, and percent canopy cover and Total Lead $(\mathrm{P}=0.02)(\mathrm{B})$ at the Gregory Mine. 
Significant correlations were not found between canopy cover and $\mathrm{N}$ concentration, canopy cover and P concentration, or canopy cover and organic matter. These were not the expected results due to the high variability in vegetation cover and production. It was expected that areas of poor vegetation would have lower nutrient levels compared to areas of good vegetation. Significant positive correlation was found between canopy cover and potassium levels $(r=0.604, \mathrm{p}=0.008$; Figure 6$)$. Biomass production was not significantly correlated with soil nutrients.

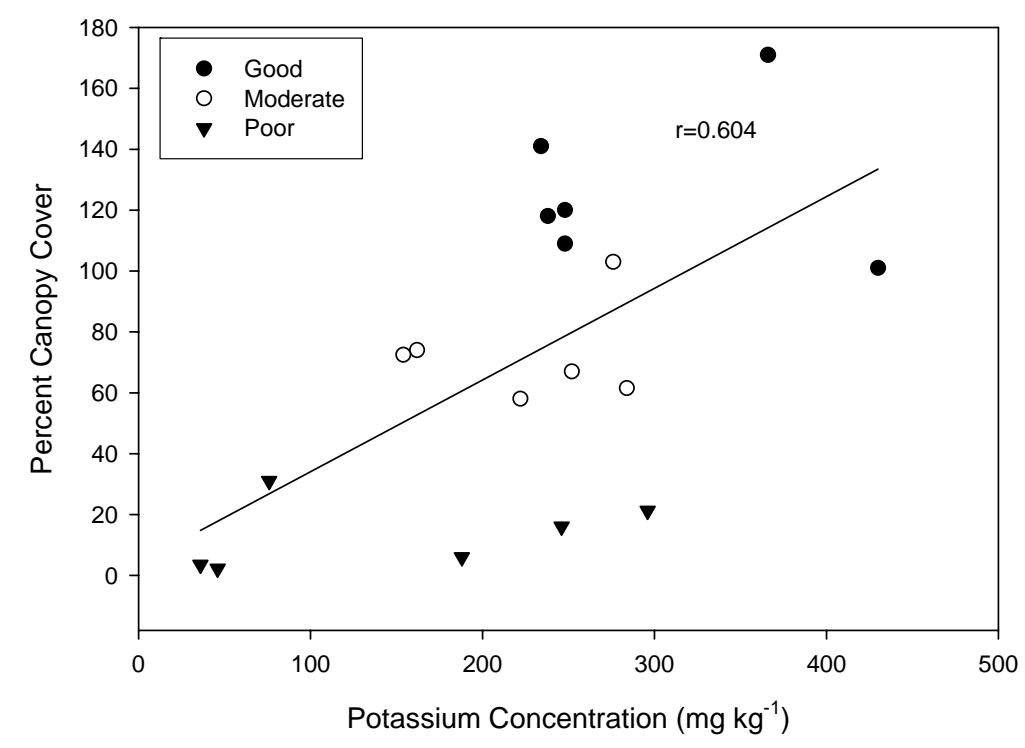

Figure 6. Correlation analysis of percent canopy and potassium concentration from the Gregory Mine ( $\mathrm{P}=0.008)$.

The species richness at this site was moderately high, with 37 species located within sample areas. Species richness (Table 14) decreased as total metal concentrations increased (Table 17) and soil pH decreased (Table 16) from Good to Moderate to Poor areas. This was the expected result based on an EPA study on the Clark Fork River in 
1999. The study concluded that species richness and sum of total metal levels were inversely correlated (as metal levels increased, species richness decreased; EPA, 1999).

\section{$\underline{\text { Comet Mine }}$}

\section{$\underline{\text { Vegetation }}$}

Vegetation at the Comet Mine was highly variable. Canopy cover estimates ranged from $0-88 \%$ and biomass production ranged from $0-3598 \mathrm{~kg} \mathrm{ha}^{-1}$ (Table 19). Barren areas were scattered throughout the site, and the species richness and diversity were extremely low (12 and 2.83 respectively). Good sample areas had dense vegetation, but mostly comprised of Agrostis alba and Agropyron trachycaulum. Moderate areas had uniform cover and slightly higher species evenness and richness. Poor areas typically had very sparse to no vegetation, and cover was limited to Agrostis alba and Agropyron trachycaulum. Twelve species were present in sample areas (Table 20) and 39 species are present at the site (Appendix B), including upland areas.

Table 19. Comet Mine vegetation summary.

\begin{tabular}{lccc}
\hline $\begin{array}{l}\text { Vegetation } \\
\text { Criteria }\end{array}$ & $\begin{array}{c}\text { Mean Cover* } \\
(\%)\end{array}$ & $\begin{array}{c}\text { Mean Production* } \\
\left(\mathrm{kg} \mathrm{ha}^{-1}\right)\end{array}$ & $\begin{array}{c}\text { Species Richness } \\
\text { in Sample Areas }\end{array}$ \\
\hline Good & $74 \pm 9 \mathrm{a}$ & $2025 \pm 926 \mathrm{a}$ & 7 \\
Moderate & $37 \pm 4 \mathrm{~b}$ & $562 \pm 198 \mathrm{~b}$ & 8 \\
Poor & $3 \pm 3 \mathrm{c}$ & $22 \pm 24 \mathrm{c}$ & 3 \\
\hline
\end{tabular}

* Cover and production values are given as means and standard deviations. a,b,c Means followed by the same letter are not significantly different at $\mathrm{P}<0.05$. 
Table 20. Species** located in sample areas at the Comet Mine.

\begin{tabular}{lllllc}
\hline $\begin{array}{l}\text { Common } \\
\text { Name }\end{array}$ & Species Name & $\begin{array}{c}\text { Major Species* } \\
(\mathrm{Y} / \mathrm{N})\end{array}$ & $\begin{array}{l}\text { Seeded } \\
(\mathrm{Y} / \mathrm{N})\end{array}$ & $\begin{array}{c}\text { Native } \\
(\mathrm{Y} / \mathrm{N})\end{array}$ & $\begin{array}{c}\text { Mean Cover } \\
(\%)\end{array}$ \\
\hline Red top & Agrostis alba & $\mathrm{Y}$ & $\mathrm{N}$ & $\mathrm{Y}$ & 60.0 \\
Slender wheatgrass & Agropyron trachycaulum & $\mathrm{Y}$ & $\mathrm{Y}$ & $\mathrm{Y}$ & 23.0 \\
Western wheatgrass & Agropyron smithii & $\mathrm{Y}$ & $\mathrm{Y}$ & $\mathrm{Y}$ & 5.5 \\
Western yarrow & Achillea millefolium & $\mathrm{Y}$ & $\mathrm{Y}$ & $\mathrm{Y}$ & 5.2 \\
Dwarf fireweed & Epilobium latifolium & $\mathrm{Y}$ & $\mathrm{N}$ & $\mathrm{Y}$ & 2.0 \\
White clover & Trifolium repens & $\mathrm{Y}$ & $\mathrm{N}$ & $\mathrm{N}$ & 1.6 \\
Field Horsetail & Equisetum arvense & $\mathrm{Y}$ & $\mathrm{N}$ & $\mathrm{Y}$ & 1.3 \\
Idaho fescue & Festuca idahoensis & $\mathrm{N}$ & $\mathrm{Y}$ & $\mathrm{Y}$ & 0.4 \\
Tufted hairgrass & Deschampsia caespitosa & $\mathrm{N}$ & $\mathrm{N}$ & $\mathrm{Y}$ & 0.3 \\
Cudweed sagewort & Artemisia ludoviciana & $\mathrm{N}$ & $\mathrm{N}$ & $\mathrm{Y}$ & 0.1 \\
Willow & Salix spp. & $\mathrm{N}$ & $\mathrm{Y}$ & $\mathrm{Y}$ & $<0.1$ \\
Unidentified Grass $\# 1$ & $\mathrm{~N}$ & & & 0.1 \\
\hline
\end{tabular}

* Major species contribute $>0.5 \%$ of the total cover within sample areas.

** Species data adapted Hitchcock et al., 1973.

Two grasses, A. alba and A. trachycaulum, were the dominant species at this site, comprising of approximately $83 \%$ of the total cover in sample areas. Two seed mixes comprised of 13 species were used at the Comet Mine during revegetation. The only seeded species found in sample areas were Agropyron smithii, Agropyron trachycaulum, F. idahoensis, and Achillea millefolium. The species Agrostis alba was not seeded, and made up $60 \%$ of the total cover. This may be due to Agrostis species being colonizers of mine sites, and displaying metal tolerance (Bleeker et al., 2002 and Farago, 1981).

\section{$\underline{\text { Soluble Metals }}$}

Soil $\mathrm{pH}$ levels for all topsoil samples were determined, and values ranged from 5.907.21. Soluble metals were determined in a subset of 10 samples. Thirty percent of the samples had high (200-800 $\left.\mathrm{mg} \mathrm{L}^{-1}\right)$ soluble zinc at $\mathrm{pH} \approx 6$, which was not expected because zinc solubility is significantly reduced at $\mathrm{pH}>5.0$ (Adriano, 2001). Natural soils 
with $\mathrm{pH}$ values near neutral typically have low soluble metal levels. Contaminated soils and mine wastes however, may exhibit high levels of soluble metals at neutral $\mathrm{pH}$ due to extremely high levels of total metals.

\section{$\underline{\text { Total Metals }}$}

Total metal and As levels were determined for all topsoil samples collected at the Comet Mine. Table 21 displays mean concentrations and sum of total metal concentrations. Metal levels in all sample areas were within or above phytotoxic levels for plant growth. Lead and Zn concentrations were particularly elevated in all vegetation areas. There was no significant difference in the sum of total metal levels between Good and Moderate areas, and both are significantly lower than total metal levels in Poor areas.

Table 21. Total metal and As levels $\left(\mathrm{mg} \mathrm{kg}^{-1}\right)$ in surface soil samples from the Comet Mine.

\begin{tabular}{|c|c|c|c|c|c|}
\hline \multirow{2}{*}{$\begin{array}{l}\text { Vegetation } \\
\text { Criteria }\end{array}$} & \multicolumn{4}{|c|}{ Metal* } & \multirow[t]{2}{*}{ Sum of all Metals } \\
\hline & As & $\mathrm{Cu}$ & $P b$ & $Z n$ & \\
\hline Good & $1004 \pm 603 \dagger$ & $348 \pm 205 \dagger$ & $1766 \pm 1214 \dagger$ & $3219 \pm 2004 \dagger$ & $7580 \pm 3535 a$ \\
\hline Moderate & $749 \pm 764 \dagger$ & $250 \pm 147 \dagger$ & $1420 \pm 1014 \dagger$ & $3170 \pm 2822 \dagger$ & $6060 \pm 3030 \mathrm{a}$ \\
\hline Poor & $3916 \pm 3444 \dagger$ & $1220 \pm 900 \dagger$ & $10988 \pm 12453 \dagger$ & $17462 \pm 13856 \dagger$ & $37356 \pm 29187 b$ \\
\hline
\end{tabular}

* Total metal levels displayed as means and standard deviations in topsoil samples within sample areas.

a,b Means followed by the same letter are not significantly different $(\mathrm{P}<0.05)$.

$\dagger$ Indicates possible phytotoxicity.

\section{Nutrients}

There were significant differences in N levels between Good and Moderate, and Moderate and Poor sample areas at the Comet Mine (Table 22). Moderate areas had significantly less soil N than Good and Poor areas. Significant difference was not found 
Table 22. Nutrient ( $\left.\mathrm{mg} \mathrm{kg}^{-1}\right)$ and organic matter (\%) concentrations in surface soil samples from the Comet Mine.

\begin{tabular}{lcccc}
\hline $\begin{array}{l}\text { Vegetation } \\
\text { Criteria }\end{array}$ & \multicolumn{4}{c}{ Macronutrient } \\
\cline { 2 - 4 } & $N$ & $P$ & $K$ & $O M$ \\
\hline & $1.9 \pm 1.9 \mathrm{a}$ & $343 \pm 192 \mathrm{a}$ & $264 \pm 119 \mathrm{a}$ & $5.4 \pm 2.6 \mathrm{a}$ \\
Good & $0.38 \pm 0.13 \mathrm{~b}$ & $315 \pm 251 \mathrm{a}$ & $230 \pm 152 \mathrm{a}$ & $5.7 \pm 3.9 \mathrm{a}$ \\
Moderate & $1.4 \pm 1.0 \mathrm{a}$ & $55.5 \pm 53.5 \mathrm{~b}$ & $94.8 \pm 22.6 \mathrm{~b}$ & $4.1 \pm 3.3 \mathrm{a}$ \\
Poor & & & & \\
\hline
\end{tabular}

a,b Means followed by the same letter are not significantly different $(p>0.05)$.

in $\mathrm{N}$ levels between Good and Poor areas. Nitrogen levels were very low in all soil samples from this site. Poor areas had very little vegetation, which may explain why $\mathrm{N}$ levels were significantly higher than in Moderate areas, where vegetation cover and production were greater. Soil $\mathrm{P}$ levels were very high in all samples at the Comet Mine. Significant difference was not found in soil P levels between Good and Moderate sample areas. Poor areas had significantly lower P levels than both Good and Moderate sample areas. Soil K levels were significantly higher in Good and Moderate areas than in Poor sample areas. Significant difference was not found in K levels between Good and Moderate sample areas. Soil K levels in Good and Moderate areas were in the medium to high range, with many samples around the critical value of $250 \mathrm{mg} \mathrm{kg}^{-1}$. Potassium levels in Poor areas were in the low to very low range, with all sample concentrations below the critical value. Significant differences were not found in soil organic matter levels between Good, Moderate, and Poor sample areas. Organic matter levels were in the medium to high range for all sample areas. 


\section{$\underline{\text { Correlation Analyses }}$}

Correlation was used to determine associations between vegetation cover and soil metal levels (Figure 7). Significant negative correlations were found between percent canopy cover and total As $(\mathrm{r}=-0.5, \mathrm{P}=0.03)$, total $\mathrm{Zn}(\mathrm{r}=-0.58, \mathrm{P}=0.01)$, total $\mathrm{Cu}(\mathrm{r}=-0.57$, $\mathrm{P}=0.01)$, total $\mathrm{Pb}(\mathrm{r}=-0.50, \mathrm{P}=0.03)$, and the sum of total metals $(\mathrm{r}=-0.58, \mathrm{P}=0.01)$. No significant relationship was found between percent canopy cover and soil $\mathrm{pH}(\mathrm{H}$-ion concentration). This was the expected result due to the narrow range of circum-neutral soil $\mathrm{pH}$ values. Metal levels in all sample areas were representative of mine waste materials, not borrow soil. There are three possible explanations for this: 1) waste materials left in place during reclamation were exposed after the borrow soil was eroded away, 2) borrow soil was placed as a thin veneer, or never placed on these areas, or 3) upward migration of metals has contaminated the clean borrow soil. Metal and As levels in all topsoil samples indicate possible upward migration. This is most likely due to waste materials located within $30 \mathrm{~cm}$ from the surface, and a positive water balance (groundwater within 1 meter).

Correlation analyses on nutrients data indicate significant positive correlation between percent canopy cover and $\mathrm{K}$ levels $(\mathrm{r}=0.61, \mathrm{P}=0.007)$, and percent canopy cover and $\mathrm{P}$ levels $(\mathrm{r}=0.596, \mathrm{P}=0.009$; Figure $8 \mathrm{~A}$ and $\mathrm{B})$. A significant positive correlation was also found between biomass production and $\mathrm{K}(\mathrm{r}=0.633, \mathrm{P}=0.005)$ and biomass production and $\mathrm{P}(\mathrm{r}=0.57, \mathrm{P}=0.01)$ (Figure 9; $\mathrm{A}, \mathrm{B})$. No association was found between vegetation attributes and organic matter or $\mathrm{N}$ levels. 


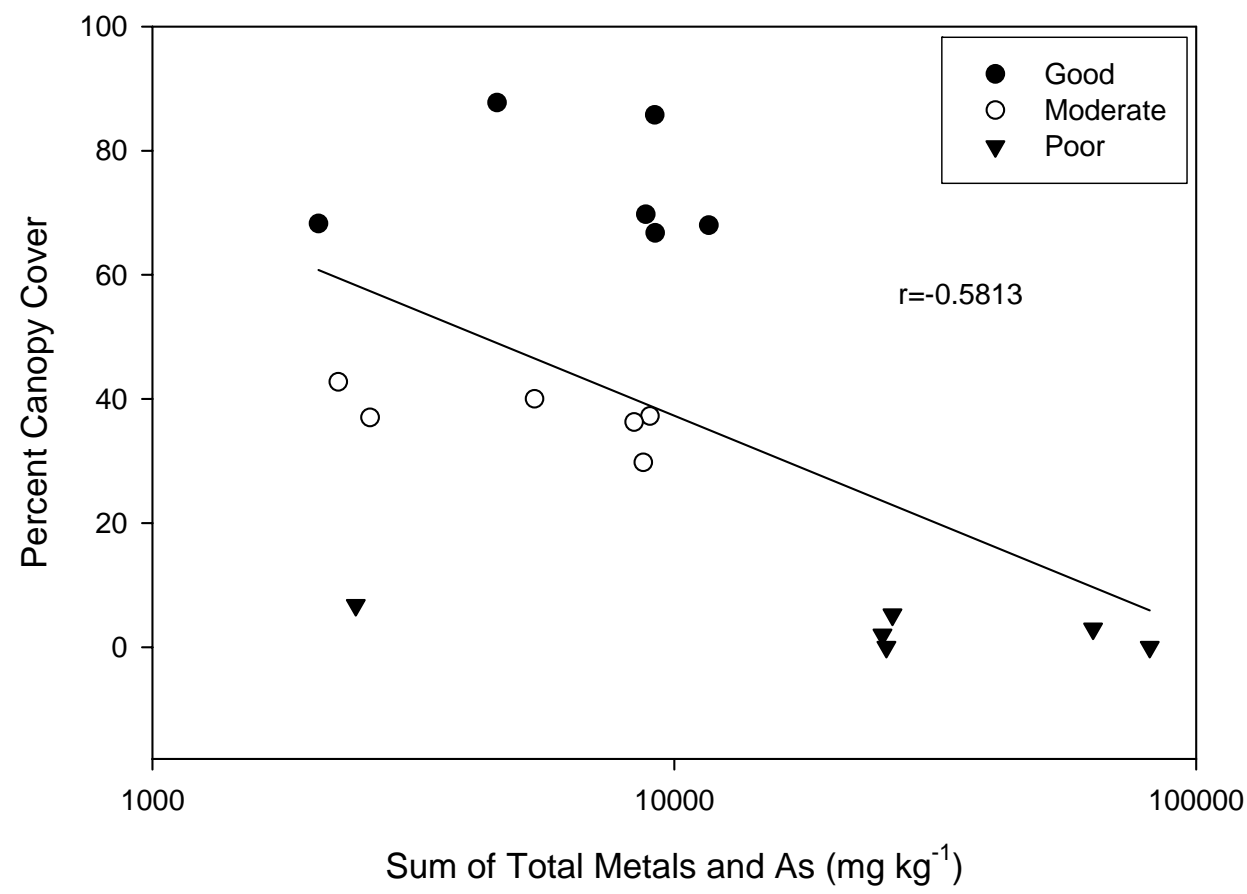

Figure 7. Correlation analysis of percent canopy cover and the sum of total metals and As levels (As, $\mathrm{Cu}, \mathrm{Pb}, \mathrm{Zn}$ ) from the Comet Mine ( $\mathrm{P}=0.01)$.

The species richness was very low, with only 12 species found in sample areas.

Species diversity was negatively correlated with high total metal levels (species diversity decreased with increasing metal levels) for contaminated areas in the Clark Fork River (CFR) Superfund site (EPA, 1999). Species richness was similar in the Good and Moderate areas, as expected, but was reduced in the Poor areas, where metals levels were two to three orders of magnitude higher. 
(A)

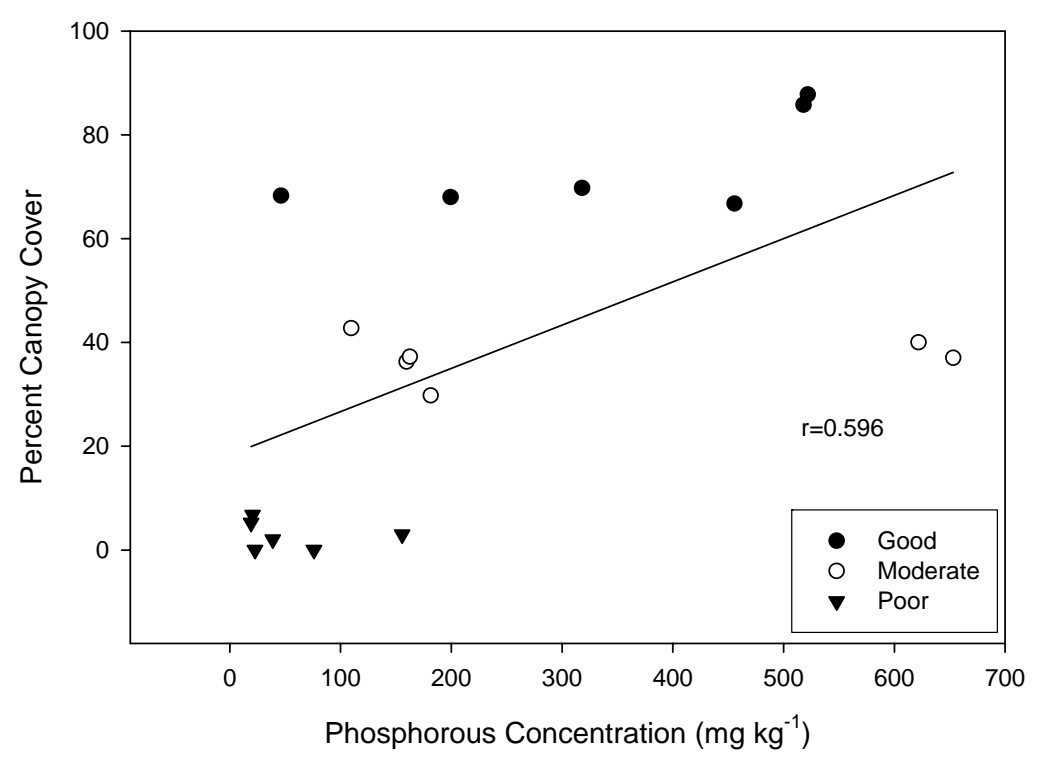

(B)

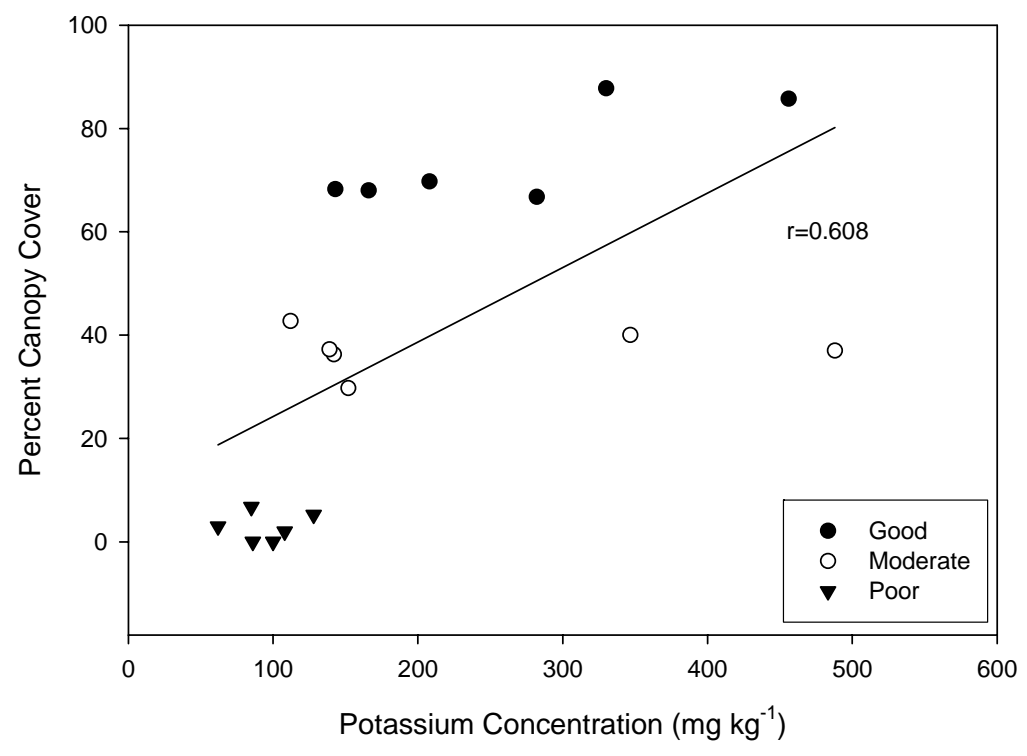

Figure 8. Correlation analysis for canopy cover and phosphorous concentration $(p=0.009)(A)$, and percent canopy cover and potassium concentration $(p=0.007)(B)$ from the Comet Mine. 
(A)

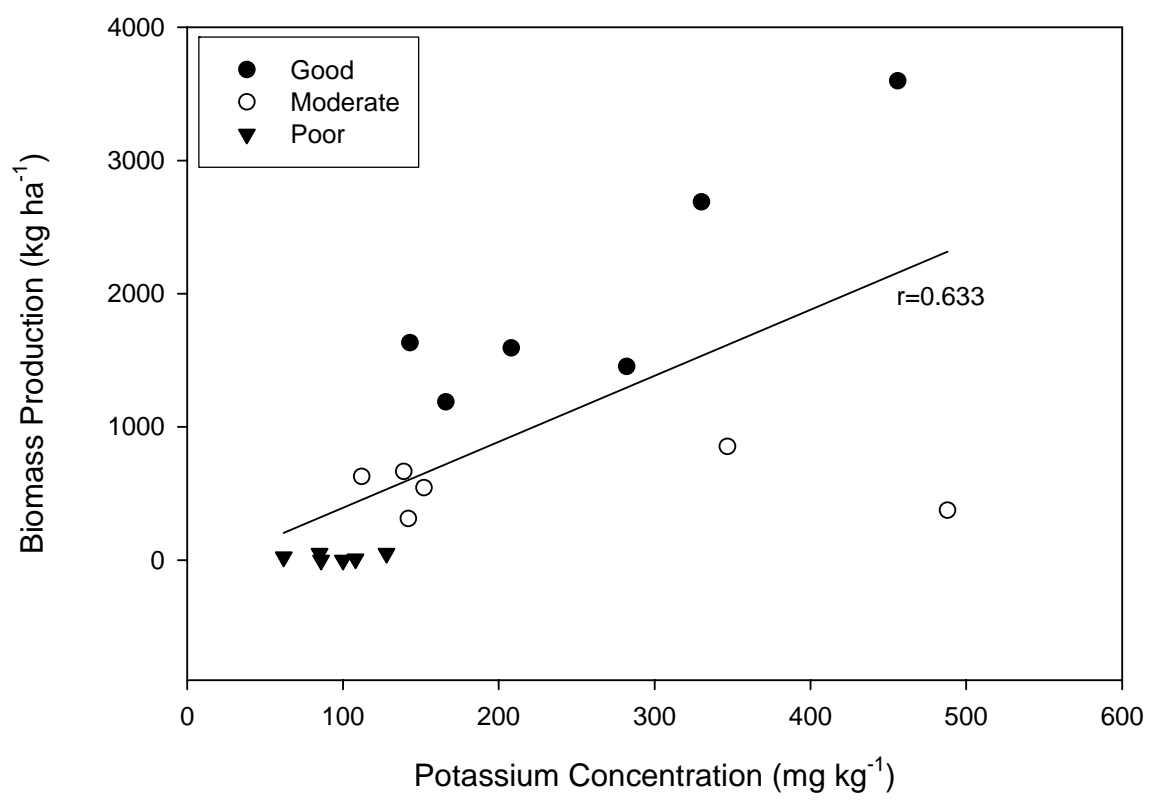

(B)

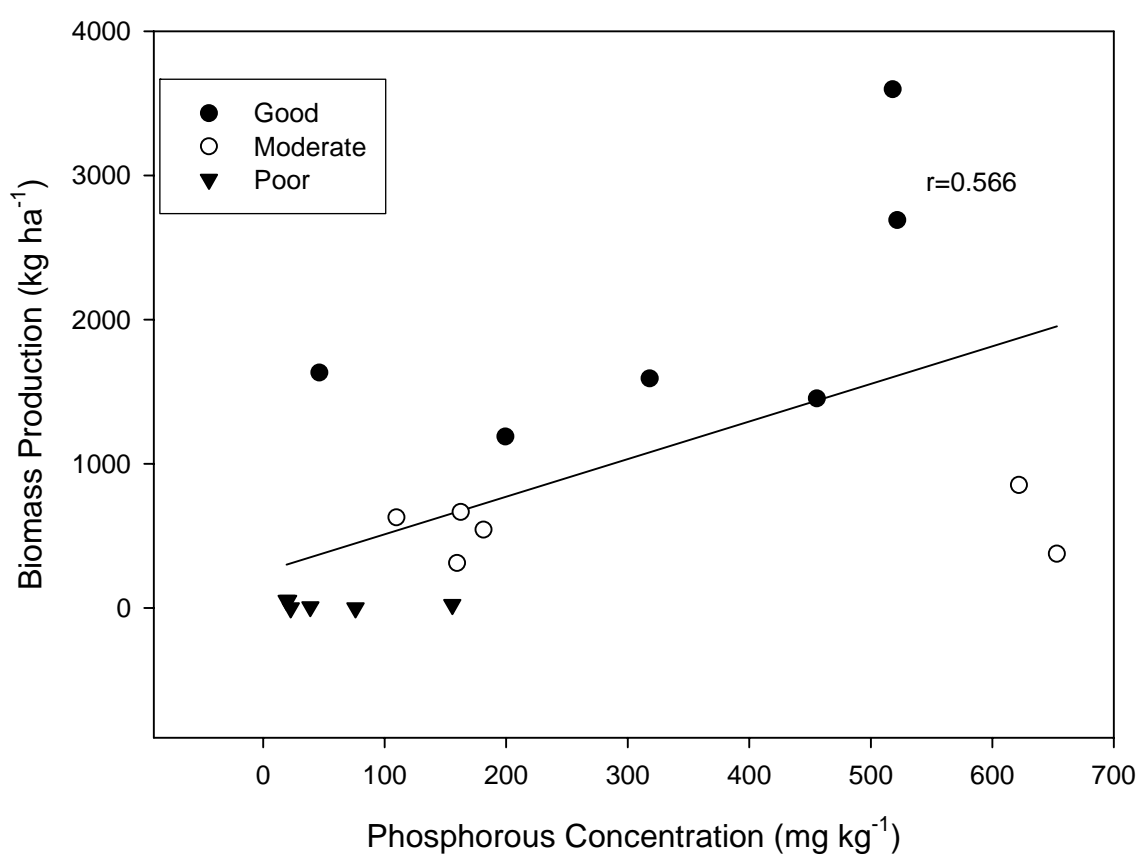

Figure 9. Correlation analysis of biomass production and potassium concentration $(p=0.005)(A)$ and biomass production and phosphorous concentration $(p=0.01)(B)$, from the Comet Mine. 


\section{$\underline{\text { High Ore Creek }}$}

\section{$\underline{\text { Vegetation }}$}

Vegetation at High Ore Creek was moderately variable, with the highest variation being in areas designated as No Removal areas. Canopy cover estimates ranged from 30$89 \%$, and biomass production ranged from 468-2288 $\mathrm{kg} \mathrm{ha}^{-1}$ (Table 23). Mean cover and production were not significantly different in No Removal and Partial Removal sample areas.

Table 23. High Ore Creek vegetation summary.

\begin{tabular}{lccc}
$\begin{array}{l}\text { Removal } \\
\text { Type }\end{array}$ & $\begin{array}{c}\text { Mean Cover* } \\
(\%)\end{array}$ & $\begin{array}{c}\text { Mean Production* } \\
\left(\mathrm{kg} \mathrm{ha}^{-1}\right)\end{array}$ & $\begin{array}{c}\text { Species Richness } \\
\text { in Sample Areas }\end{array}$ \\
\hline Partial & $70 \pm 17 \mathrm{a}$ & $1446 \pm 328 \mathrm{a}$ & 12 \\
No removal & $63 \pm 29 \mathrm{a}$ & $1448 \pm 918 \mathrm{a}$ & 21 \\
\hline
\end{tabular}

* Cover and production values are given means and standard deviations.

a Means followed by the same letter are not significantly different at $\mathrm{P}<0.05$.

Cover in all areas was relatively uniform, and there were no barren areas within the study area. Study areas contained 28 species (Table 24), and the entire site had 50 species (Appendix B). Two seed mixes comprised of 12 species were applied in the revegetation phase of reclamation. The seeded species that made up $>0.5 \%$ of the total cover in sample areas included Agropyron spicatum, F. idahoensis, K. cristata, Agropyron trachycaulum, and Achillea millefolium. The species Agrostis alba, J. balticus, E. arvense, and M. officinalis were not seeded species, and comprised of $44 \%$ of the total cover in sample areas. The only species to be present in both No and Partial Removal areas were Agrostis alba and Achillea millefolium (Appendix A). 
Table 24. Species** located in sample areas at High Ore Creek.

\begin{tabular}{|c|c|c|c|c|c|}
\hline $\begin{array}{l}\text { Common } \\
\text { Name }\end{array}$ & Species Name & $\begin{array}{c}\text { Major Species* } \\
(Y / N)\end{array}$ & $\begin{array}{l}\text { Seeded } \\
(Y / N)\end{array}$ & $\begin{array}{l}\text { Native } \\
(\mathrm{Y} / \mathrm{N})\end{array}$ & $\begin{array}{c}\text { Relative Cover } \\
\text { (\%) }\end{array}$ \\
\hline Western Yarrow & Achillea millefolium & $\mathrm{Y}$ & $\mathrm{Y}$ & $\mathrm{Y}$ & 25.0 \\
\hline Red top & Agrostis alba & $\mathrm{Y}$ & $\mathrm{N}$ & $\mathrm{Y}$ & 15.0 \\
\hline Baltic rush & Juncus balticus & $\mathrm{Y}$ & $\mathrm{N}$ & $\mathrm{Y}$ & 12.6 \\
\hline Idaho fescue & Festuca idahoensis & $\mathrm{Y}$ & $\mathrm{Y}$ & $\mathrm{Y}$ & 12.0 \\
\hline Yellow sweetclover & Melilotus officinalis & $\mathrm{Y}$ & $\mathrm{N}$ & $\mathrm{N}$ & 9.3 \\
\hline Field Horsetail & Equisetum arvense & $\mathrm{Y}$ & $\mathrm{N}$ & $\mathrm{Y}$ & 7.4 \\
\hline $\begin{array}{l}\text { Bluebunch- } \\
\text { Wheatgrass }\end{array}$ & Agropyron spicatum & $\mathrm{Y}$ & $\mathrm{Y}$ & $\mathrm{Y}$ & 3.3 \\
\hline Red clover & Trifolium pratense & $\mathrm{Y}$ & $\mathrm{N}$ & $\mathrm{N}$ & 2.7 \\
\hline Prarie Junegrass & Koeleria cristata & $\mathrm{Y}$ & $\mathrm{Y}$ & $\mathrm{Y}$ & 1.9 \\
\hline Slender wheatgrass & Agropyron trachycaulum & $\mathrm{Y}$ & $\mathrm{Y}$ & $\mathrm{Y}$ & 1.4 \\
\hline $\begin{array}{l}\text { Intermediate- } \\
\text { wheatgrass }\end{array}$ & Agropyron intermedium & $\mathrm{Y}$ & $\mathrm{N}$ & $\mathrm{N}$ & 1.3 \\
\hline Willow & Salix spp. & $\mathrm{Y}$ & $\mathrm{Y}$ & $\mathrm{Y}$ & 1.0 \\
\hline Bull thistle & Cirsium vulgare & $\mathrm{Y}$ & $\mathrm{N}$ & $\mathrm{N}$ & 0.9 \\
\hline Quaking aspen & Populus tremuloides & $\mathrm{Y}$ & $\mathrm{N}$ & $\mathrm{Y}$ & 0.9 \\
\hline Western wheatgrass & Agropyon smithii & $\mathrm{Y}$ & $\mathrm{N}$ & $\mathrm{Y}$ & 0.8 \\
\hline Nebraska sedge & Carex nebrascensis & $\mathrm{Y}$ & $\mathrm{N}$ & $\mathrm{Y}$ & 0.7 \\
\hline Tufted hairgrass & Deschampsia caespitosa & $\mathrm{N}$ & $\mathrm{Y}$ & $\mathrm{Y}$ & 0.4 \\
\hline Cudweed sagewort & Artemisia ludoviciana & $\mathrm{N}$ & $\mathrm{N}$ & $\mathrm{Y}$ & 0.4 \\
\hline Dandelion & Taraxacum officinale & $\mathrm{N}$ & $\mathrm{N}$ & $\mathrm{N}$ & 0.3 \\
\hline Canada bluegrass & Poa compressa & $\mathrm{N}$ & $\mathrm{N}$ & $\mathrm{N}$ & 0.2 \\
\hline Dwarf fireweed & Epilobium latifolium & $\mathrm{N}$ & $\mathrm{N}$ & $\mathrm{Y}$ & 0.1 \\
\hline $\begin{array}{l}\text { Columbia- } \\
\text { needlegrass }\end{array}$ & Achnatherum nelsonii & $\mathrm{N}$ & $\mathrm{Y}$ & $\mathrm{Y}$ & $<0.1$ \\
\hline Ragwort & Senecio spp. & $\mathrm{N}$ & $\mathrm{N}$ & $\mathrm{Y}$ & $<0.1$ \\
\hline \multicolumn{2}{|c|}{ Unidentified Forb \#1-2, 6-8 } & $\mathrm{N}$ & & & 1.0 \\
\hline
\end{tabular}

* Major species contribute $>0.5 \%$ of the total cover within sample areas.

** Species data adapted from Hitchcock et al., 1973.

\section{$\underline{\text { Soluble Metals }}$}

Soil $\mathrm{pH}$ levels were determined in all samples, and ranged from 5.48-7.63 (Table 25).

As expected, soluble metal levels were very low, due to relatively high $\mathrm{pH}$ values.

Soluble Zn and Cd levels were significantly higher in No Removal areas than in Partial

Removal areas. Soluble $\mathrm{As}, \mathrm{Cu}$ and $\mathrm{Pb}$ concentrations were not significantly different

between No and Partial Removal areas. 
Table 25. Soil pH (standard units) and soluble metal and As ( $\mathrm{mg} \mathrm{L}^{-1}$ ) levels in surface soil samples from High Ore Creek.

\begin{tabular}{|c|c|c|c|c|c|c|c|}
\hline \multirow{2}{*}{$\begin{array}{l}\text { Vegetation } \\
\text { Criteria }\end{array}$} & \multirow{2}{*}{$\begin{array}{l}\text { Soil } p H \\
\text { Top** }\end{array}$} & \multirow{2}{*}{$\begin{array}{l}\text { Soil pH } \\
\text { Bottom** }\end{array}$} & \multicolumn{5}{|c|}{ Metal* } \\
\hline & & & As & $\overline{C d}$ & $\mathrm{Cu}$ & $\overline{P b}$ & $\mathrm{Zn}$ \\
\hline Partial & 7.23a & 7.39 & $.40 \pm .29 \mathrm{a}$ & $.01 \pm .005 a$ & $.088 \pm .035 a$ & $<.1 \mathrm{a}$ & $0.19 \pm 0.07 \mathrm{a}$ \\
\hline No & 5.99a & 5.90 & $.17 \pm .09 a$ & $.23 \pm .22 b$ & $.077 \pm .034 a$ & $.17 \pm .13 a$ & $58.9 \pm 77.4 \mathrm{~b}$ \\
\hline
\end{tabular}

* $\quad$ Metals data are presented as means and standard deviations.

** Top increment was typically $0-30 \mathrm{~cm}$ and bottom increment was $30-60 \mathrm{~cm}$, though, there was some variation in these increments, and sample collection was delineated as a function of soil layers, not distinct numerical increments.

a,b Means followed by the same letter are not significantly different at $\mathrm{P}<0.05$. 


\section{$\underline{\text { Total Metals }}$}

Total metal and arsenic levels were determined for topsoil samples collected at High Ore Creek (Table 26). Metals levels in No Removal areas were significantly higher than in Partial Removal areas, because tailings were left in place in No Removal areas. The total metal concentrations in No Removal areas are well above the phytotoxic range for all metals.

Table 26. Total metal and As levels ( $\mathrm{mg} \mathrm{kg}^{-1}$ ) in surface soil samples from High Ore Creek.

\begin{tabular}{lccccc}
\hline Removal & \multicolumn{4}{c}{ Metal* $^{*}$} & \multirow{2}{*}{ Sum of all Metals } \\
\cline { 2 - 5 } Type & $A s$ & $C u$ & $P b$ & $Z n$ & \\
\hline Partial & $120 \pm 118 \dagger$ & $72 \pm 33$ & $323 \pm 336 \dagger$ & $353 \pm 292 \dagger$ & $769 \pm 925 \mathrm{a}$ \\
No & $3993 \pm 1244 \dagger$ & $498 \pm 221 \dagger$ & $2735 \pm 1541 \dagger$ & $4806 \pm 2872 \dagger$ & $12126 \pm 6880 \mathrm{~b}$ \\
\hline
\end{tabular}

* Total metal levels displayed as means and standard deviations in topsoil samples within sample areas.

a,b Means followed by the same letter are not significantly different at $\mathrm{P}<0.05$.

$\dagger$ Indicates possible phytotoxicity.

\section{Nutrients}

There were no significant differences in $\mathrm{N}$ and organic matter concentrations between No Removal and Partial Removal areas at High Ore Creek (Table 27). Soil N levels were very low for all samples collected at High Ore Creek, most likely due to sample collection during peak growing season. Soil organic matter levels were in the low medium range for all samples collected at this site. 
Table 27. Nutrient* (mg kg-1) and organic matter* (\%) concentrations in surface soil samples from High Ore Creek.

\begin{tabular}{lcccc}
\hline $\begin{array}{l}\text { Removal } \\
\text { Type }\end{array}$ & \multicolumn{3}{c}{ Macronutrient** } \\
\cline { 2 - 4 } & $\mathrm{N}-\mathrm{NO}_{3}$ & $\mathrm{P}$ & $\mathrm{K}$ & \multirow{2}{*}{$\mathrm{OM}$} \\
\hline Partial & $3.0 \pm 2.4 \mathrm{a}$ & $303 \pm 106 \mathrm{a}$ & $167 \pm 9.9 \mathrm{a}$ & $4.5 \pm .93 \mathrm{a}$ \\
No & $1.8 \pm 1.5 \mathrm{a}$ & $23.8 \pm 5.6 \mathrm{~b}$ & $53.8 \pm 18.9 \mathrm{~b}$ & $2.9 \pm 1.4 \mathrm{a}$ \\
\hline
\end{tabular}

a,b Means followed by the same letter are not significantly different ( $\mathrm{p}>0.05)$.

Significant differences were found in P and K levels between No Removal and Partial Removal areas. Phosphorous levels were very high in Partial Removal areas, and low in No Removal areas. Potassium concentrations were in the medium range for Partial Removal areas, and in the very low range for No Removal areas. Potassium levels in No Removal areas may restrict plant growth due to very low concentrations.

\section{Correlation Analyses}

Correlation was used to determine associations among vegetation and soil chemistry. Significant correlations were not found between vegetation attributes and soil $\mathrm{pH}$ or metal levels.

Correlation was also used to determine associations between vegetation attributes and soil nutrients. Significant correlations were not found among vegetation cover or biomass and any soil nutrient. This may be due to the low number of samples collected at this site.

Although the cover and production were not significantly different between No and Partial Removal areas, the species composition was very different. No Removal areas 
had much higher species richness than Partial Removal areas (21 and 12 respectively). This was not expected due to the high levels of total metals present in No Removal areas. The plant community in No Removal Areas was dominated by Agrostis alba, Juncus balticus, and Equisetum arvense, which made up approximately $70 \%$ of the total cover. Partial removal areas were dominated by F. idahoensis and Achillea millefolium, which comprised of $64 \%$ of the total cover. The only species that occurred in both removal types were Agrostis alba and Achillea millefolium. Differences in species richness may be a function of the age of the plant community. Plant communities in No Removal areas have had several decades to establish, while Partial Removal areas were seeded 5 years ago. The difference in species composition may also be a result of the soil metal levels. The dominant species in No Removal areas may have metal tolerant genotypes that have adapted the metal enriched soils over time. The dominant species in Partial Removal areas were seeded species that are reproducing successfully and are adapted to the borrow soil properties. 


\section{CHAPTER 5}

\section{CONCLUSIONS}

This study suggests that vegetation attributes of cover, production, species richness, and diversity were generally related to soil metal levels and acidity at the study sites. Aesthetically, the sites were greatly improved, however, there were mine wastes residing under the soil cap and on the soil surface, which may affect the long-term sustainability of these sites. A major determining factor in the effectiveness of revegetation is the depth of applied coversoil. Bell (2002) suggests sulfidic wastes need to be buried by one meter of non-contaminated materials and $10-20 \mathrm{~cm}$ of coversoil replacement for effective revegetation. Barth and Martin (1984) determined that 101-152 cm of coversoil was necessary over acidic materials and $40 \mathrm{~cm}$ of coversoil was necessary over non-acidic materials for effective revegetation. Coversoil depths varied at all sites, however, no areas had sufficient coversoil with reference to either coversoil report. Specifically, Some areas at the Gregory and Comet Mine sites had little to no coversoil, and mine wastes were exposed on the soil surface.

All three sites had soil metal levels considerably higher, often several orders of magnitude greater than regional background metal levels. This was not expected, but is most likely a result of the reclamation implementation. Monterroso et al. (1998) found decreased plant growth following coversoil application due to upward migration of contaminated materials. There are indications of upward movement of both low $\mathrm{pH}$ solutions and metals from underlying contaminants into the soil cap, based on 
soil chemistry findings, vegetation dieback, and field observations. A shallow water table (45-60 cm below the surface) was observed at all three sites, and may be a major concern for the mobility of contaminants into the clean soil cap, consistent with Tordoff et al. (2000), Kapustka (2002), and Bell (2002). The Gregory Mine and High Ore Creek had soil metal levels drastically lower than pre-reclamation waste materials (Pioneer Technologies Inc., 1995), and had well-established vegetation in most areas. The Comet Mine had extremely elevated metal levels, indicative of residual wastes, not coversoil, and had the lowest vegetation cover, production, and richness.

\section{Vegetation Attributes and Soil Chemistry}

Significant negative correlations between vegetation attributes (cover, biomass, species richness) and soil chemistry ( $\mathrm{pH}$, As and metal levels) were found at both the Gregory Mine and the Comet Mine. Percent canopy cover and biomass production were negatively and significantly correlated to total As and metal levels at both sites.

Significant negative correlation was also found between species richness and soil metal levels. These relationships are consistent with an earlier EPA phytotoxicity model developed for the Clark Fork River and Anaconda Smelter Superfund sites (EPA, 1999).

\section{Gregory Mine}

Reclamation at the Gregory Mine has been effective in creating a productive vegetation community. Average canopy cover was approximately 70\%, with 60 species present across the site; however, low $\mathrm{pH}$ soils exist $30 \mathrm{~cm}$ below the surface, and soil $\mathrm{pH}$ 
was strongly correlated to percent canopy cover and biomass production. This may be problematic in the future if upward migration of acidic water into the soil cap occurs. There is evidence that upward migration is occurring, with topsoil $\mathrm{pH}$ values below 5 in some areas. Soil $\mathrm{pH}$ values could continue to decrease, affecting the overall plant production, cover, and species richness. Only the most tolerant plant species may be able to persist. Soluble and total metal levels were not correlated to canopy cover or biomass production with the exception of total lead concentration.

\section{Comet Mine}

Reclamation at the Comet Mine has been effective in producing an aesthetically improved landscaped with moderate vegetation cover. The established vegetation should reduce erosion, and protect the surface water from runoff of contaminated sediments. The metal levels at this site are extremely elevated; up to three orders of magnitude higher than background levels. Strong negative correlations were found between the canopy cover and the sum of total metals, as well as canopy cover and total concentrations of each element ( $\mathrm{As}, \mathrm{Zn}, \mathrm{Pb}$, and $\mathrm{Cu}$ ). The average canopy cover at the site was approximately 38\%, and extensive barren areas exist in many areas within the riparian zone. Metal salts were observed on the soil surface in dry weather. There are mine wastes residing within $30 \mathrm{~cm}$ of the soil surface, and a shallow water table $(<60 \mathrm{~cm}$ below the soils surface) was observed during field sampling. A total of 39 species were identified, with very low species diversity. Metal tolerant species, such as Agrostis species, dominated most sample areas. The metal concentrations in surface soils may 
continue to rise with upward migration of soluble metal salts, decreasing the effectiveness of reclamation and revegetation. Overall, it is concluded that maintenance needs to be done on this site to inhibit the deterioration of the vegetation community, and the upward migration of contaminants.

\section{High Ore Creek}

The reclamation at High Ore Creek was very effective in Partial/Total Removal areas. The soil metal levels were only slightly elevated above background, and soil $\mathrm{pH}$ values were near neutral. Surface crusts were not observed in Partial/Total Removal areas, indicating that upward migration of contaminants may not be occurring. No Removal areas had metal levels one to two orders of magnitude higher than Partial/Total Removal areas. However, neither total metal levels nor $\mathrm{pH}$ were correlated with biomass production or plant cover at this time. Plant community composition in No Removal areas are quite different than that in Partial/Total Removal areas; however, there was no difference in the mean cover or mean production between removal types. This suggests that species composition may be influenced by total metal levels; driving the differences in species composition at this site. Metal tolerant species dominated No Removal areas where soil metal levels are elevated. The results of this study were inconclusive as to which removal type was the most effective. Metal levels were elevated in No Removal areas, but the percent cover and biomass production were not significantly different compared to Partial Removal areas. No Removal areas had higher species richness, but were dominated by metal tolerant species. Partial/Total Removal areas had lower species 
richness, but had less variation in cover and production, and higher occurrence of grass species.

\section{Established Vegetation}

The grass species Agrostis alba was not seeded at any of the study sites, but was the dominant grass species in most areas. This species colonized all reclaimed sites, most likely due to high metal tolerance and aggressive colonization of disturbed sites (Farago, 1981; Bleeker et al., 2002; Munshower, 1998). Two seeded species, Achillea millefolium and F. idahoensis, successfully established on all sites. There is some question as to whether the Festuca spp. is a mix of F. idahoensis and Festuca ovina. The species F. ovina is a known metal tolerant grass species (Farago, 1981) and is physically very similar to F. idahoensis. Several of the native seeded species were rare or had not established at these sites. In particular, F. scabrella, S. viridula, Agropyron spicatum, $P$. compressa, Calamagrostis spp., and Linum lewisii were not successful and would not be recommended for use at similar mine sites. Monitoring changes in the species richness and diversity over time will be the most effective way to determine what species are successfully establishing at metalliferous mine reclamation sites. It is recommended that the seed mix be adjusted and unsuccessful species eliminated in order to increase cost effectiveness and allow faster establishment of successful species. Seeding metal tolerant species can significantly increase the success of revegetation, allowing for faster establishment and long term sustainability. Often, metal tolerant genotypes are present on or near disturbances, and seeds could be harvested for the reclamation project. This 
would allow for faster re-establishment and greater sustainability than commercial seeds, because the plants are adapted to the unfavorable conditions present at metalliferous mine sites. The Bridger Plant Materials Center has been researching metal tolerant plant genotypes for ten years, using seeds collected from plants growing on the Clark Fork River Superfund Site. The seeds were collected and cultivated, with the goal of releasing native plant materials that demonstrate high tolerance to acidic conditions and metal contamination (Marty, 2000). Metal tolerant plants may not provide ideal forage for grazing species, thus it is important to plan the seed mix for revegetation based on post reclamation land use.

\section{Monitoring Reclamation Effectiveness}

Long-term monitoring of reclaimed abandoned mine sites is essential for understanding the effectiveness of reclamation. The data presented in this thesis are not intended to imply causal relationships between soil chemistry and vegetation attributes, but to provide insight into associations that may impact the future of the Gregory Mine, the Comet Mine, and High Ore Creek reclamation. These quantitative data provide baseline information that could be used to track future changes in soil chemistry and vegetation at these sites. A monitoring plan should include the following:

- Topsoil sampling with analytical analysis of soil $\mathrm{pH}$, soluble metal levels (if sites are acidic), total metal levels (specifically $\mathrm{As}, \mathrm{Cu}, \mathrm{Pb}$, and $\mathrm{Zn}$ ), and if possible, soil nutrients (N, P, K, and OM).

- Canopy cover estimation (by species).

- Species richness and species composition estimation. 
- Staking the perimeter of barren areas and locations into a GPS database.

- Establishing permanent photo points.

Monitoring based on these factors will increase the understanding of what is occurring at these sites over time. It is recommended that monitoring occur every three years.

Qualitative evaluation of reclaimed sites provides a relatively inexpensive and efficient method for tracking changes, and can be an indicator of when quantitative monitoring should occur. Qualitative evaluation should be used to observe changes to ascertain if sites are degrading and at what pace. This could be done on an annual basis, using a check-sheet that includes questions about public safety, repositories, removal areas, wetland and streambank areas, and upland areas. Development of a qualitative monitoring program will help land managers assess long term vegetation stability and target problem areas for future remediation. 


\section{REFERENCES CITED}

American Public Health Association. 1989. Standard Methods for the examination of water and wastewater. $17^{\text {th }}$ edition. American Public Health Association, American Waterworks Association, and Water pollution Control Federation, Washington D. C.

Adriano, Domy C. 2001. Trace elements in terrestrial environments: Biogeochemistry, bioavailability, and risks of metals, second edition. Springer, New York, NY. 867p.

Baker, A. J. M. 1987. Metal tolerance. New Phytologist. 106: 93-111.

Barth, R. C. and B. K. Martin. 1984. Soil depth requirements for revegetation of surface mined ares in Wyoming, Montana, and North Dakota. Journal of Environmental Quality. 13: 399-404

Bell, L. C. 2002. Physical limitations. Pages 38-49 in A. D. Bradshaw and Ming H. Wong, editors. The Restoration and Management of Derelict Land, Modern Approaches. World Scientific, New Jersey.

Bleeker, P. M., A. G. L. Assuncao, P. M. Tiega, T. de Koe, and J. A. C. Verkleij. 2002. Revegetation of the acidic, As contaminated Jales mine spoil tips using a combination of spoil amendments and tolerant grasses. The Science of the Total Environment. 300:1-13.

BLM, 2001. U. S. Department of Interior/Bureau of land Management. High Ore Creek Streamside Tailings Reclamation. http://www.mt.blm.gov/aml/HOC_Report/HOC_Report.htm

Bradshaw, A. D. 1997. Restoration of mined lands-using natural processes. Ecological Engineering. 8:255-269.

Brown, Ray, Micheal C. Amacher, Walter F. Mueggler, and Janic Kotuby-Amacher. 2003. Reestablishing natural succession on acidic mine spoils at high elevation: Long-term ecological restoration. Research Paper RMRS-RP-41. Ogden UT: U. S. Department of Agriculture, Forest Service, Rocky Mountain Research Station. 49 p.

Brown, Sally, Mark Sprenger, Amanda Maxemchuk, and Harry Compton. 2005. Ecosystem function in alluvial tailings after biosolids and lime addition. Journal of Environmental Quality. 34: 139-148.

Browne, Michael, Ben Quinones, and James Madison. 2001. High Ore Creek Watershed Restoration. Presented at the 25th Annual National Association of Abandoned Mine Land Programs Conference, Park City, Utah. 
Caruccio, F. T., L. R. Hossner, and G. Geidel. 1988. Pyritic materials: Acid drainage, soil acidity, and liming. Pages 159-189 in L. R. Hossner, editor. Reclamation of Surface Mined Lands, Volume 1. CRC Press, Boca Raton, FL.

CDM Federal. 1997. Anaconda ARWWS baseline ecological risk assessment. Used in the ARWWS OU Record of Decision.

CH2MHill. 1987a. Assessment of the toxicity of arsenic , cadmium, lead, and zinc in soil and plants and livestock in the Helena Valley of Montana for East Helena Site (ASARCO), East Helena, Montana. Prepared by the Reclamation Research Unit, Montana State University.

CH2MHill. 1987b. Assessment of the toxicity of copper, mercury, selenium, silver, and thallium in soil and plants in the Helena Valley of Montana for East Helena Site (ASARCO), East Helena, Montana. Prepared by the Reclamation Research Unit, Montana State University.

Daubenmire, R. 1959. A canopy-coverage method of vegetation analysis. Northwest Science. 33: 43-64.

Dickinson, N. M. Soil degradation and nutrients. 2002. Pages 50-65 in A. D. Bradshaw and Ming H. Wong, editors. The Restoration and Management of Derelict Land, Modern Approaches. World Scientific, New Jersey.

Farago, M. E. 1981. Metal tolerant plants. Coordination Chemistry Reviews. 36:155182.

Foth, Henry D., and Boyd G. Ellis. 1997. Soil Fertility, Second Edition. CRC Press, Boca Raton, FL. 290p.

Hitchcock, C. L. and A. Cronquist. 1973. Flora of the Pacific Northwest. University of Washington Press, Seattle. 730pp.

Johnson, M. S., J. A. Cooke, and J. K. W. Stevenson. 1994. Revegetation of metalliferous wastes and land after metal mining. Pages 31-48 in R. E. Hester and R. M. Harrison, editors. Mining and its Environmental Impact. Royal Society of Chemistry, Cambridge, United Kingdom.

Jones, Clain, and Jeff Jacobsen. 2005. Phosphorous cycling, testing, and fertilizer recommendations. Montana State University Extension Service, Publication 4449-4. 
Jurinak, J. J., Joe Bowden, Fred Samson, and Tom Portal. 1987. Electrical conductivity. Pages 27-34 in R. Dean Williams and Gerald E. Schuman, editors. Reclaiming Mine Soils and Overburden in the Western United States, Analytic Parameters and Procedures. Soil Conservation Society of America, Ankeny, Iowa. 336p.

Kabata-Pendias, A. and H. Pendias. 1992. Trace elements in soils and plants, $2^{\text {nd }}$ edition. CRC Press, Boca Raton, FL. 365p.

Kabata-Pendias, A. 2001. Trace elements in soils and plants, $3^{\text {rd }}$ edition. CRC Press, Boca Raton FL. 413p.

Kahn, A. G. 2002. The importance of microbes. Pages 80-92 in A. D. Bradshaw and Ming H. Wong, editors. The Restoration and management of derelict land, modern approaches. World Scientific, New Jersey.

Kapustka, L. A. 2002. Phytotoxicity tests on soils from the Grant-Kohrs ranch national historic site, Deer Lodge, Montana. Final report prepared for the University of Montana, Missoula under contract to the National Park Service. 37 pages.

Kapustka, L.A., Lipton, J., Galbraith, H., Cacela, D., and K. LeJune. 1995. Metal and arsenic impacts to soils, vegetation communities and wildlife habitat in Southwest Montana uplands contaminated by smelter emissions: II. Laboratory phytotoxicity studies. Environmental Toxicology and Chemistry. 14:1905-1912.

Korb, Nathan, Clain Jones, and Jeff Jacobsen. 2005. Potassium cycling, testing, and fertilizer recommendations. Montana State University Extension Service, Publication 4449-5.

Krzaklewski, Wojciech and Marcin Pietrzykowski. 2002. Selected physio-chemical properties of zinc and lead ore tailings and their biological stabilization. Water, Air, and Soil Pollution. 141: 125-142.

Marty, L. 2000. The use of local ecotypes for the revegetation of acid/heavy metal contaminated lands in western Montana. Proceedings from the 2000 Billings Land Reclamation Symposium, Billings, Montana. Pages 218-228.

Meharg, Andrew A. and Mark Macnair. 1991. The mechanisms of arsenate tolerance in Deschampsia caespitosa (L.) Beauv. and Agrostis capillaris L. New Phytologist. 119: 291-297. 
Monterroso, C., F. Macias, A. Gil Bueno, and C. Val Caballero. 1998. Evaluation of the land reclamation project at the As Pontes Mine (NW Spain) in relation to the suitability of the soil for plant growth. Land Degradation and Development. 9: 441451.

Munshower. F. F. 1994. Practical Handbook of Disturbed Land Revegetation. Lewis Publishers, Boca Raton, FL. 265p.

Munshower, F. F. 1998. Grasses and grasslike species for revegetation of disturbed lands in the northern Great Plains and adjacent areas with comments about some wetland species. RRU, Bozeman, MT.

Neuman, D. R., Jennings, S. R., and M. K. Reeves. 2002. Plant growth and soil metal concentrations: a spatial effects model. Paper presented at the 2002 National Meeting of the American Society of Mining and Reclamation, Lexington, KY, June 9-13, 2002. Published by ASMR.

Olympus Technical Services. 1999. Montana Department of Environmental QualityMine Waste Cleanup Bureau. Invitation for bid; Comet Mine and millsite phase II reclamation project, Jefferson County, Montana. Prepared by Olympus Technical Services, August 1999.

Pioneer Technolgies Inc. 1995. Montana Department of State Lands-Abandoned Mine Reclamation Bureau. Abandoned Hardrock Mine Priorities Sites. 1995 Summary Report. Prepared by Pioneer Technical Services, Inc. April, 1995.

Pioneer Technologies Inc. 1996. Montana Department of Environmental Cleanup, Mine Waste Cleanup Bureau. Final reclamation work plan for the Comet Mine. Prepared by Pioneer Technical Services, Inc. May 1996.

Pioneer Technologies. 2000. United States Army Corps of Engineers. High Ore Creek streamside tailings reclamation project final construction report. Prepared by Pioneer Technologies Inc, December 2000.

Pioneer Technologies Inc. 2003. Montana Department of Environmental Quality-Mine Waste Cleanup Bureau. Draft 2003 reclaimed mine inspection report for the Comet Mine and millsite. Prepared by Pioneer Technologies Inc., Novermber, 2003.

PTI. 1997. Anaconda regional soils remedial investigation. Report prepared for Atlantic Richfield Company by PTI Environmental Services, Bellevue, WA. February 1997. Document No. 2210403/460194. 
Ross, Robert L. and Harold E. Hunter. 1976. Climax vegetation of Montana, based on soils and climate. U.S. Department of Agriculture, Soil Conservation Service. Bozeman, MT. 64 p.

Shu, W. S., Z. H. Ye, Z. Q. Zhang, C. Y. Lan, and M. H. Wong. 2005. Natural colonization of plants on five lead/zinc mine tailings in southern China. Restoration Ecology. 13: 49-60.

Smith R. A. H. and A. D. Bradshaw. 1972. Stabilization of toxic mine wastes by the use of tolerant plant populations. Transactions of the Institute of Mineral Metallurgy, Sect. A. 81: 230-237.

Smith, R. A. H. and A. D. Bradshaw. 1979. The use of metal tolerant plant populations for the reclamation of metalliferous wastes. Journal of Applied Ecology. 16: 595612.

Surbrugg, John Edward. 1982. Copper and zinc tolerance in two Montana grass species growing on copper mill tailings. Montana State University Master's Thesis.

Tetra-Tech, 2001. Montana Department of Environmental Cleanup, Mine Waste Cleanup Bureau. Final reclamation investigation report for the Gregory Mine and associated areas, Colorado Mining District, Jefferson County, MT. Prepared by Tetra-Tech, February, 2001.

Tilling, Robert. 1973. Boulder Batholith, Montana; A product of two contemporaneous but chemically distinct magma series. Geological Society of America Bulletin. 84: 3879-3700.

Tilling, Robert. 1974. Composition and time relations of plutonic and associated volcanic rocks, Boulder Batholith region, Montana. Geological Society of America Bulletin. 85: 1925-1930.

Tordoff, G. M., A. J. M. Baker, and A. J. Willis. 2000. Current approaches to the revegetation of metaliferous mine wastes. Chemosphere. 41:219-228.

U.S.D.A. Salinity Laboratory Staff. 1969. Diagnosis of saline and alkali soils. Agriculture Handbook No. 60: U.S. Department of Agriculture, Washington, DC. 160p.

U. S. EPA. 1999. Clark Fork River Ecological Assessment. Prepared by ISSI Consulting Group for the U.S. Environmental Protection Agency, Region VII, Denver, CO. December, 1999. 
Von Frenckell-Insam, Beatrix A. K and Thomas C. Hutchinson. 1993. Occurance of heavy metal tolerance and co-tolerance in Deschampsia cespitosa (L.) Beauv. from European and Canadian populations. New Phytologist. 125: 555-564.

Wali, Mohan K. 1999. Ecological succession and rehabilitation of disturbed terrestrial ecosystems. Plant and Soil. 213: 195-220.

Wu, Lin and Janis Antonovics. 1975. Zinc and copper uptake by Agrostis stolonifera, tolerant to both zinc and copper. New Phytologist. 75: 231-237.

Ye, Z. H., A. J. M. Baker, and M. H. Wong. 2002. Problems of Toxicities. Pages 66-79 in A. D. Bradshaw and Ming H. Wong, editors. The Restoration and management of derelict land, modern approaches. World Scientific, New Jersey. 
APPENDICES 
APPENDIX A:

\section{VEGETATION DATA}


Table 28. Field canopy cover data, total percent cover by species and sample area, standard deviation and species frequency from the Gregory Mine.

\begin{tabular}{|c|c|c|c|c|c|c|c|c|c|c|c|c|c|c|c|}
\hline & & Frame \# & 1 & 2 & 3 & 4 & 5 & 6 & 7 & 8 & 9 & 10 & & & \\
\hline $\begin{array}{c}\text { Transect } \\
I^{*}\end{array}$ & $\begin{array}{l}\text { Common } \\
\text { Name }\end{array}$ & Species Name & \begin{tabular}{|l|} 
Mid \\
point
\end{tabular} & $\begin{array}{l}\text { Mid } \\
\text { point }\end{array}$ & $\begin{array}{c}\text { Mid } \\
\text { point }\end{array}$ & $\begin{array}{c}\text { Mid } \\
\text { point }\end{array}$ & $\begin{array}{c}\text { Mid } \\
\text { point }\end{array}$ & $\begin{array}{c}\text { Mid } \\
\text { point }\end{array}$ & $\begin{array}{l}\text { Mid } \\
\text { point }\end{array}$ & $\begin{array}{c}\text { Mid } \\
\text { point }\end{array}$ & $\begin{array}{l}\text { Mid } \\
\text { point }\end{array}$ & \begin{tabular}{|l|} 
Mid \\
point
\end{tabular} & $\begin{array}{l}\text { Mean } \\
\% \text { cover }\end{array}$ & $\begin{array}{l}\text { Standard } \\
\text { Deviation }\end{array}$ & Frequency \\
\hline \multirow[t]{12}{*}{$\begin{array}{c}\text { GR-SB- } \\
\text { G-01 } \\
\end{array}$} & Red top & Agrostis alba & 62.5 & 62.5 & 62.5 & 97.5 & 97.5 & 85 & 62.5 & 62.5 & 62.5 & 37.5 & 69.25 & 18.64 & 100 \\
\hline & Idaho fescue & $\begin{array}{c}\text { Festuca } \\
\text { idahoensis }\end{array}$ & 15 & 15 & 15 & 15 & 15 & 15 & 15 & 15 & 15 & 2.5 & 13.75 & 3.95 & 100 \\
\hline & Timothy & Phleum pratense & 0 & 0 & 2.5 & 0 & 2.5 & 2.5 & 2.5 & 2.5 & 2.5 & 2.5 & 1.75 & 1.21 & 70 \\
\hline & Switch grass & $\begin{array}{l}\text { Panicum } \\
\text { virgatum }\end{array}$ & 0 & 0 & 0 & 2.5 & 0 & 0 & 0 & 0 & 0 & 0 & 0.25 & 0.79 & 10 \\
\hline & $\begin{array}{l}\text { Rough } \\
\text { fescue }\end{array}$ & $\begin{array}{l}\text { Festuca } \\
\text { scabrella }\end{array}$ & 0 & 0 & 0 & 2.5 & 0 & 0 & 0 & 0 & 2.5 & 0 & 0.5 & 1.05 & 20 \\
\hline & Red clover & $\begin{array}{l}\text { Trifolium } \\
\text { pratense }\end{array}$ & 0 & 2.5 & 0 & 0 & 0 & 0 & 0 & 0 & 0 & 0 & 0.25 & 0.79 & 10 \\
\hline & $\begin{array}{l}\text { White } \\
\text { yarrow }\end{array}$ & $\begin{array}{c}\text { Achillea } \\
\text { millefolium }\end{array}$ & 85 & 62.5 & 62.5 & 62.5 & 37.5 & 62.5 & 37.5 & 37.5 & 15 & 15 & 47.75 & 22.90 & 100 \\
\hline & $\begin{array}{l}\text { Dwarf } \\
\text { fireweed }\end{array}$ & $\begin{array}{l}\text { Epilobium } \\
\text { latifolium }\end{array}$ & 0 & 2.5 & 0 & 2.5 & 2.5 & 2.5 & 2.5 & 2.5 & 2.5 & 2.5 & 2 & 1.05 & 80 \\
\hline & Strawberry & Fragaria vesca & 0 & 0 & 0 & 0 & 2.5 & 0 & 0 & 0 & 0 & 0 & 0.25 & 0.79 & 10 \\
\hline & Pussytoes & Antennaria spp. & 0 & 0 & 0 & 0 & 0 & 0 & 0 & 2.5 & 0 & 0 & 0.25 & 0.79 & 10 \\
\hline & White clover & Trifolium repens & 0 & 0 & 0 & 0 & 0 & 0 & 0 & 2.5 & 2.5 & 2.5 & 0.75 & 1.21 & 30 \\
\hline & Goldenrod & $\begin{array}{c}\text { Solidago } \\
\text { missouriensis }\end{array}$ & 0 & 0 & 0 & 0 & 0 & 0 & 0 & 15 & 0 & 0 & 1.5 & 4.74 & 10 \\
\hline
\end{tabular}


Table 28. Continued.

\begin{tabular}{|c|c|c|c|c|c|c|c|c|c|c|c|c|c|c|c|}
\hline & & Frame \# & 1 & 2 & 3 & 4 & 5 & 6 & 7 & 8 & 9 & 10 & & & \\
\hline \multirow[t]{8}{*}{$\begin{array}{c}\text { Transect } \\
I^{*}\end{array}$} & $\begin{array}{l}\text { Common } \\
\text { Name }\end{array}$ & Species Name & $\begin{array}{l}\text { Mid } \\
\text { point }\end{array}$ & $\begin{array}{c}\text { Mid } \\
\text { point }\end{array}$ & $\begin{array}{c}\text { Mid } \\
\text { point }\end{array}$ & $\begin{array}{c}\text { Mid } \\
\text { point }\end{array}$ & $\begin{array}{c}\text { Mid } \\
\text { point }\end{array}$ & $\begin{array}{c}\text { Mid } \\
\text { point }\end{array}$ & $\begin{array}{l}\text { Mid } \\
\text { point }\end{array}$ & $\begin{array}{c}\text { Mid } \\
\text { point }\end{array}$ & $\begin{array}{l}\text { Mid } \\
\text { point }\end{array}$ & \begin{tabular}{|c|} 
Mid \\
point
\end{tabular} & $\begin{array}{l}\text { Mean } \\
\% \text { cover }\end{array}$ & $\begin{array}{l}\text { Standard } \\
\text { Deviation }\end{array}$ & Frequency \\
\hline & $\begin{array}{c}\text { Unidentified } \\
\text { forb \#1 }\end{array}$ & & 0 & 2.5 & 0 & 0 & 0 & 0 & 2.5 & 2.5 & 2.5 & 0 & 1 & 1.29 & 40 \\
\hline & $\begin{array}{l}\text { Unidentified } \\
\text { forb \#2 }\end{array}$ & & 0 & 0 & 0 & 15 & 0 & 0 & 0 & 2.5 & 0 & 0 & 1.75 & 4.72 & 20 \\
\hline & $\begin{array}{l}\text { Unidentified } \\
\text { forb \#3 }\end{array}$ & & 0 & 0 & 0 & 0 & 0 & 2.5 & 0 & 0 & 0 & 0 & 0.25 & 0.79 & 10 \\
\hline & Bare ground & & 2.5 & 2.5 & 2.5 & 2.5 & 2.5 & 2.5 & 2.5 & 2.5 & 2.5 & 15 & 3.75 & 3.95 & \\
\hline & Rock & & 2.5 & 2.5 & 2.5 & 2.5 & 2.5 & 2.5 & 2.5 & 15 & 2.5 & 15 & 5 & 5.27 & \\
\hline & Litter & & 2.5 & 2.5 & 2.5 & 2.5 & 2.5 & 2.5 & 2.5 & 2.5 & 2.5 & 2.5 & 2.5 & 0.00 & \\
\hline & & Total Live & 162.5 & 147.5 & 143 & 198 & 158 & 170 & 123 & 145 & 105 & 62.5 & 141.25 & & \\
\hline \multirow[t]{6}{*}{$\begin{array}{c}\text { GR-SB- } \\
\text { G-02 }\end{array}$} & Red top & Agrostis alba & 62.5 & 85 & 85 & 97.5 & 0 & 0 & 0 & 0 & 0 & 0 & 33 & 43.43 & 40 \\
\hline & Timothy & Phleum pratense & 37.5 & 0 & 37.5 & 0 & 0 & 0 & 0 & 0 & 0 & 0 & 7.5 & 15.81 & 20 \\
\hline & $\begin{array}{l}\text { Idaho } \\
\text { fescue }\end{array}$ & $\begin{array}{c}\text { Festuca } \\
\text { idahoensis }\end{array}$ & 15 & 15 & 15 & 2.5 & 15 & 37.5 & 37.5 & 37.5 & 37.5 & 62.5 & 27.5 & 17.87 & 100 \\
\hline & $\begin{array}{l}\text { Kentucky } \\
\text { bluegrass }\end{array}$ & Poa pratensis & 0 & 15 & 0 & 2.5 & 0 & 15 & 15 & 2.5 & 37.5 & 15 & 10.25 & 11.87 & 70 \\
\hline & $\begin{array}{l}\text { Thickspike } \\
\text { wheatgrass }\end{array}$ & $\begin{array}{c}\text { Agropyron } \\
\text { dasystachyum }\end{array}$ & 0 & 0 & 0 & 0 & 15 & 0 & 0 & 0 & 0 & 0 & 1.5 & 4.74 & 10 \\
\hline & Sedge & Carex spp. & 0 & 0 & 0 & 2.5 & 0 & 15 & 15 & 15 & 0 & 0 & 4.75 & 7.12 & 40 \\
\hline
\end{tabular}


Table 28. Continued.

\begin{tabular}{|c|c|c|c|c|c|c|c|c|c|c|c|c|c|c|c|}
\hline & & Frame \# & 1 & 2 & 3 & 4 & 5 & 6 & 7 & 8 & 9 & 10 & & & \\
\hline \multirow[t]{18}{*}{$\begin{array}{c}\text { Transect } \\
I^{*}\end{array}$} & $\begin{array}{l}\text { Common } \\
\text { Name }\end{array}$ & Species Name & \begin{tabular}{|c|} 
Mid \\
point
\end{tabular} & $\begin{array}{l}\text { Mid } \\
\text { point }\end{array}$ & $\begin{array}{c}\text { Mid } \\
\text { point }\end{array}$ & $\begin{array}{c}\text { Mid } \\
\text { point }\end{array}$ & $\begin{array}{c}\text { Mid } \\
\text { point }\end{array}$ & $\begin{array}{c}\text { Mid } \\
\text { point }\end{array}$ & $\begin{array}{l}\text { Mid } \\
\text { point }\end{array}$ & $\begin{array}{c}\text { Mid } \\
\text { point }\end{array}$ & $\begin{array}{l}\text { Mid } \\
\text { point }\end{array}$ & \begin{tabular}{|c|} 
Mid \\
point
\end{tabular} & $\begin{array}{l}\text { Mean } \\
\% \text { cover }\end{array}$ & $\begin{array}{l}\text { Standard } \\
\text { Deviation }\end{array}$ & Frequency \\
\hline & Baltic rush & Juncus balticus & 0 & 0 & 0 & 0 & 2.5 & 0 & 15 & 0 & 0 & 0 & 1.75 & 4.72 & 20 \\
\hline & Purple aster & $\begin{array}{c}\text { Machaeranthera } \\
\text { canescens }\end{array}$ & 0 & 0 & 0 & 2.5 & 0 & 2.5 & 0 & 0 & 0 & 0 & 0.5 & 1.05 & 20 \\
\hline & Alfalfa & Medicago sativa & 0 & 0 & 0 & 0 & 0 & 37.5 & 0 & 0 & 0 & 0 & 3.75 & 11.86 & 10 \\
\hline & Red clover & $\begin{array}{l}\text { Trifolium } \\
\text { pratense }\end{array}$ & 0 & 0 & 0 & 0 & 0 & 0 & 0 & 37.5 & 0 & 0 & 3.75 & 11.86 & 10 \\
\hline & Woods rose & Rosa woodsii & 0 & 0 & 2.5 & 0 & 0 & 0 & 0 & 2.5 & 0 & 0 & 0.5 & 1.05 & 20 \\
\hline & Yarrow & $\begin{array}{l}\text { Achillea } \\
\text { millefolium }\end{array}$ & 37.5 & 62.5 & 37.5 & 37.5 & 85 & 85 & 62.5 & 62.5 & 85 & 85 & 64 & 20.76 & 100 \\
\hline & Tar weed & Madia sativa & 2.5 & 2.5 & 0 & 0 & 0 & 0 & 0 & 0 & 0 & 0 & 0.5 & 1.05 & 20 \\
\hline & Strawberry & & 0 & 2.5 & 0 & 0 & 0 & 0 & 0 & 2.5 & 0 & 0 & 0.5 & 1.05 & 20 \\
\hline & $\begin{array}{l}\text { Dwarf } \\
\text { fireweed }\end{array}$ & $\begin{array}{l}\text { Epilobium } \\
\text { latifolium }\end{array}$ & 0 & 2.5 & 2.5 & 15 & 0 & 0 & 0 & 0 & 0 & 0 & 2 & 4.68 & 30 \\
\hline & $\begin{array}{c}\text { Tall } \\
\text { buttercup }\end{array}$ & $\begin{array}{l}\text { Ranunculus } \\
\text { acris }\end{array}$ & 0 & 2.5 & 0 & 0 & 0 & 0 & 0 & 0 & 0 & 2.5 & 0.5 & 1.05 & 20 \\
\hline & $\begin{array}{c}\text { Sulfur } \\
\text { cinquefoil }\end{array}$ & Potentilla recta & 0 & 15 & 0 & 0 & 0 & 0 & 15 & 0 & 0 & 0 & 3 & 6.32 & 20 \\
\hline & $\begin{array}{c}\text { Unidentified } \\
\text { forb \#3 }\end{array}$ & & 15 & 15 & 15 & 15 & 2.5 & 0 & 0 & 0 & 0 & 0 & 6.25 & 7.57 & 50 \\
\hline & Rye grass & & 0 & 0 & 0 & 0 & 0 & 0 & 0 & 2.5 & 0 & 0 & 0.25 & 0.79 & 10 \\
\hline & Bare ground & & 2.5 & 2.5 & 2.5 & 2.5 & 2.5 & 2.5 & 15 & 2.5 & 2.5 & 2.5 & 3.75 & 3.95 & \\
\hline & Rock & & 2.5 & 2.5 & 0 & 2.5 & 2.5 & 2.5 & 2.5 & 2.5 & 2.5 & 15 & 3.5 & 4.12 & \\
\hline & Litter & & 2.5 & 2.5 & 15 & 2.5 & 15 & 2.5 & 15 & 15 & 2.5 & 15 & 8.75 & 6.59 & \\
\hline & & Total Live & 170 & 217.5 & 195 & 175 & 120 & 193 & 160 & 163 & 160 & 165 & 171.75 & & \\
\hline
\end{tabular}


Table 28. Continued.

\begin{tabular}{|c|c|c|c|c|c|c|c|c|c|c|c|c|c|c|c|}
\hline & & Frame \# & 1 & 2 & 3 & 4 & 5 & 6 & 7 & 8 & 9 & 10 & & & \\
\hline $\begin{array}{c}\text { Transect } \\
I^{*}\end{array}$ & $\begin{array}{l}\text { Common } \\
\text { Name }\end{array}$ & Species Name & \begin{tabular}{|c|} 
Mid \\
point
\end{tabular} & $\begin{array}{l}\text { Mid } \\
\text { point }\end{array}$ & $\begin{array}{c}\text { Mid } \\
\text { point }\end{array}$ & $\begin{array}{c}\text { Mid } \\
\text { point }\end{array}$ & $\begin{array}{l}\text { Mid } \\
\text { point }\end{array}$ & $\begin{array}{c}\text { Mid } \\
\text { point }\end{array}$ & $\begin{array}{l}\text { Mid } \\
\text { point }\end{array}$ & $\begin{array}{l}\text { Mid } \\
\text { point }\end{array}$ & $\begin{array}{l}\text { Mid } \\
\text { point }\end{array}$ & \begin{tabular}{|c|} 
Mid \\
point
\end{tabular} & $\begin{array}{l}\text { Mean } \\
\% \text { cover }\end{array}$ & $\begin{array}{l}\text { Standard } \\
\text { Deviation }\end{array}$ & Frequency \\
\hline \multirow[t]{11}{*}{$\begin{array}{c}\text { GR-SB- } \\
\text { G-03 }\end{array}$} & Red top & Agrostis alba & 37.5 & 15 & 15 & 37.5 & 2.5 & 62.5 & 37.5 & 97.5 & 85 & 62.5 & 45.25 & 31.17 & 100 \\
\hline & $\begin{array}{l}\text { Idaho } \\
\text { fescue }\end{array}$ & $\begin{array}{c}\text { Festuca } \\
\text { idahoensis }\end{array}$ & 15 & 37.5 & 15 & 37.5 & 62.5 & 62.5 & 15 & 0 & 0 & 0 & 24.5 & 24.26 & 70 \\
\hline & Sedge & Carex sp.? & 62.5 & 37.5 & 37.5 & 15 & 15 & 2.5 & 0 & 0 & 15 & 15 & 20 & 20.07 & 80 \\
\hline & $\begin{array}{c}\text { Tufted } \\
\text { hairgrass }\end{array}$ & $\begin{array}{c}\text { Deschampsia } \\
\text { caespitosa }\end{array}$ & 0 & 0 & 15 & 0 & 2.5 & 0 & 0 & 0 & 0 & 0 & 1.75 & 4.72 & 20 \\
\hline & Baltic rush & Juncus balticus & 0 & 0 & 0 & 0 & 2.5 & 15 & 0 & 0 & 15 & 15 & 4.75 & 7.12 & 40 \\
\hline & $\begin{array}{c}\text { Thickspike } \\
\text { wheatgrass }\end{array}$ & $\begin{array}{c}\text { Agropyron } \\
\text { dasystachyum }\end{array}$ & 0 & 0 & 0 & 0 & 15 & 0 & 0 & 0 & 0 & 0 & 1.5 & 4.74 & 10 \\
\hline & White clover & Trifolium repens & 0 & 0 & 0 & 0 & 0 & 15 & 37.5 & 0 & 0 & 0 & 5.25 & 12.27 & 20 \\
\hline & $\begin{array}{l}\text { Broadleaf } \\
\text { plantain }\end{array}$ & Plantago major & 0 & 0 & 0 & 0 & 0 & 0 & 0 & 0 & 2.5 & 0 & 0.25 & 0.79 & 10 \\
\hline & $\begin{array}{c}\text { Smooth } \\
\text { scouringrush }\end{array}$ & $\begin{array}{l}\text { Equisetum } \\
\text { laevigatum }\end{array}$ & 15 & 2.5 & 2.5 & 2.5 & 2.5 & 2.5 & 2.5 & 2.5 & 2.5 & 15 & 5 & 5.27 & 100 \\
\hline & Yarrow & $\begin{array}{l}\text { Achillea } \\
\text { millefolium }\end{array}$ & 0 & 0 & 0 & 15 & 15 & 0 & 15 & 0 & 0 & 0 & 4.5 & 7.25 & 30 \\
\hline & $\begin{array}{l}\text { Quaking } \\
\text { aspen }\end{array}$ & $\begin{array}{l}\text { Populus } \\
\text { tremuloides }\end{array}$ & 0 & 0 & 0 & 0 & 2.5 & 0 & 0 & 0 & 0 & 2.5 & 0.5 & 1.05 & 20 \\
\hline
\end{tabular}


Table 28. Continued.

\begin{tabular}{|c|c|c|c|c|c|c|c|c|c|c|c|c|c|c|c|}
\hline & & Frame \# & 1 & 2 & 3 & 4 & 5 & 6 & 7 & 8 & 9 & 10 & & & \\
\hline \multirow[t]{9}{*}{$\begin{array}{c}\text { Transect } \\
\text { ID* }^{*}\end{array}$} & $\begin{array}{l}\text { Common } \\
\text { Name }\end{array}$ & Species Name & $\begin{array}{l}\text { Mid } \\
\text { point }\end{array}$ & $\begin{array}{l}\text { Mid } \\
\text { point }\end{array}$ & $\begin{array}{l}\text { Mid } \\
\text { point }\end{array}$ & $\begin{array}{l}\text { Mid } \\
\text { point }\end{array}$ & $\begin{array}{l}\text { Mid } \\
\text { point }\end{array}$ & $\begin{array}{c}\text { Mid } \\
\text { point }\end{array}$ & $\begin{array}{l}\text { Mid } \\
\text { point }\end{array}$ & $\begin{array}{l}\text { Mid } \\
\text { point }\end{array}$ & $\begin{array}{c}\text { Mid } \\
\text { point }\end{array}$ & $\begin{array}{l}\text { Mid } \\
\text { point }\end{array}$ & $\begin{array}{c}\text { Mean } \\
\% \text { cover }\end{array}$ & $\begin{array}{l}\text { Standard } \\
\text { Deviation }\end{array}$ & Frequency \\
\hline & $\begin{array}{l}\text { Dwarf } \\
\text { fireweed }\end{array}$ & $\begin{array}{l}\text { Epilobium } \\
\text { latifolium }\end{array}$ & 0 & 0 & 0 & 0 & 0 & 0 & 15 & 0 & 0 & 0 & 1.5 & 4.74 & 10 \\
\hline & $\begin{array}{c}\text { Unidentified } \\
\text { forb } \# 1\end{array}$ & & 0 & 0 & 0 & 0 & 0 & 2.5 & 0 & 0 & 0 & 0 & 0.25 & 0.79 & 10 \\
\hline & $\begin{array}{c}\text { Unidentified } \\
\text { forb \#3 }\end{array}$ & & 0 & 0 & 0 & 2.5 & 2.5 & 15 & 15 & 0 & 0 & 2.5 & 3.75 & 6.04 & 50 \\
\hline & Moss & & 0 & 0 & 0 & 0 & 0 & 0 & 0 & 0 & 2.5 & 2.5 & 0.5 & 1.05 & 20 \\
\hline & Bare ground & & 15 & 37.5 & 37.5 & 37.5 & 15 & 15 & 37.5 & 15 & 2.5 & 37.5 & 25 & 13.69 & \\
\hline & Litter & & 2.5 & 15 & 2.5 & 2.5 & 2.5 & 2.5 & 2.5 & 2.5 & 37.5 & 15 & 8.5 & 11.44 & \\
\hline & Rock & & 2.5 & 2.5 & 2.5 & 2.5 & 2.5 & 2.5 & 2.5 & 2.5 & 2.5 & 2.5 & 2.5 & 0.00 & \\
\hline & & Total Live & 130 & 92.5 & 85 & 110 & 123 & 178 & 138 & 100 & 122.5 & 115 & 118.75 & & \\
\hline \multirow[t]{5}{*}{$\begin{array}{c}\text { GR-SB- } \\
\text { M-01 }\end{array}$} & Red top & Agrostis alba & 37.5 & 37.5 & 15 & 2.5 & 62.5 & 2.5 & 37.5 & 15 & 62.5 & 62.5 & 33.5 & 23.98 & 100 \\
\hline & $\begin{array}{l}\text { Idaho } \\
\text { fescue }\end{array}$ & $\begin{array}{c}\text { Festuca } \\
\text { idahoensis }\end{array}$ & 0 & 0 & 0 & 15 & 15 & 15 & 2.5 & 15 & 37.5 & 15 & 11.5 & 11.62 & 70 \\
\hline & Toad rush & Juncus bufonius & 0 & 0 & 0 & 2.5 & 0 & 0 & 0 & 0 & 0 & 0 & 0.25 & 0.79 & 10 \\
\hline & Timothy & Phleum pratense & 0 & 0 & 0 & 0 & 0 & 0 & 0 & 15 & 0 & 0 & 1.5 & 4.74 & 10 \\
\hline & Yarrow & $\begin{array}{c}\text { Achillea } \\
\text { millefolium }\end{array}$ & 15 & 0 & 2.5 & 2.5 & 15 & 2.5 & 15 & 15 & 15 & 2.5 & 8.5 & 6.89 & 90 \\
\hline
\end{tabular}


Table 28. Continued.

\begin{tabular}{|c|c|c|c|c|c|c|c|c|c|c|c|c|c|c|c|}
\hline & & Frame \# & 1 & 2 & 3 & 4 & 5 & 6 & 7 & 8 & 9 & 10 & & & \\
\hline \multirow[t]{15}{*}{$\begin{array}{c}\text { Transect } \\
I^{*}\end{array}$} & $\begin{array}{l}\text { Common } \\
\text { Name }\end{array}$ & Species Name & \begin{tabular}{|c|} 
Mid \\
point
\end{tabular} & $\begin{array}{l}\text { Mid } \\
\text { point }\end{array}$ & $\begin{array}{c}\text { Mid } \\
\text { point }\end{array}$ & $\begin{array}{c}\text { Mid } \\
\text { point }\end{array}$ & $\begin{array}{c}\text { Mid } \\
\text { point }\end{array}$ & $\begin{array}{c}\text { Mid } \\
\text { point }\end{array}$ & $\begin{array}{l}\text { Mid } \\
\text { point }\end{array}$ & $\begin{array}{c}\text { Mid } \\
\text { point }\end{array}$ & $\begin{array}{l}\text { Mid } \\
\text { point }\end{array}$ & \begin{tabular}{|c|} 
Mid \\
point
\end{tabular} & $\begin{array}{l}\text { Mean } \\
\% \text { cover }\end{array}$ & $\begin{array}{l}\text { Standard } \\
\text { Deviation }\end{array}$ & Frequency \\
\hline & Tar weed & Madia sativa & 2.5 & 0 & 2.5 & 0 & 0 & 0 & 0 & 0 & 2.5 & 2.5 & 1 & 1.29 & 40 \\
\hline & $\begin{array}{c}\text { Dwarf } \\
\text { fireweed }\end{array}$ & $\begin{array}{l}\text { Epilobium } \\
\text { latifolium }\end{array}$ & 2.5 & 0 & 0 & 0 & 0 & 2.5 & 0 & 0 & 15 & 2.5 & 2.25 & 4.63 & 40 \\
\hline & White clover & Trifolium repens & 0 & 2.5 & 0 & 0 & 0 & 2.5 & 0 & 0 & 0 & 2.5 & 0.75 & 1.21 & 30 \\
\hline & Strawberry & Fragaria vesca & 0 & 0 & 0 & 0 & 0 & 2.5 & 0 & 0 & 0 & 0 & 0.25 & 0.79 & 10 \\
\hline & $\begin{array}{l}\text { Sulfur } \\
\text { cinquefoil }\end{array}$ & Potentilla recta & 0 & 0 & 0 & 0 & 0 & 2.5 & 0 & 0 & 0 & 0 & 0.25 & 0.79 & 10 \\
\hline & $\begin{array}{c}\text { Unidentified } \\
\text { forb \#1 }\end{array}$ & & 0 & 2.5 & 0 & 0 & 0 & 0 & 0 & 0 & 0 & 0 & 0.25 & 0.79 & 10 \\
\hline & $\begin{array}{c}\text { Unidentified } \\
\text { forb \#2 }\end{array}$ & & 0 & 0 & 0 & 0 & 0 & 0 & 0 & 0 & 2.5 & 0 & 0.25 & 0.79 & 10 \\
\hline & $\begin{array}{c}\text { Unidentified } \\
\text { forb } \# 3\end{array}$ & & 0 & 2.5 & 2.5 & 0 & 0 & 2.5 & 0 & 0 & 0 & 2.5 & 1 & 1.29 & 40 \\
\hline & Bull thistle & Cirsium vulgare & 0 & 0 & 0 & 2.5 & 0 & 0 & 0 & 0 & 0 & 0 & 0.25 & 0.79 & 10 \\
\hline & Rock & & 15 & 37.5 & 62.5 & 37.5 & 2.5 & 37.5 & 37.5 & 62.5 & 2.5 & 2.5 & 29.75 & 23.17 & 100 \\
\hline & Bare ground & & 37.5 & 15 & 15 & 37.5 & 37.5 & 15 & 15 & 15 & 15 & 15 & 21.75 & 10.87 & \\
\hline & Litter & & 2.5 & 2.5 & 2.5 & 2.5 & 15 & 15 & 15 & 2.5 & 2.5 & 2.5 & 6.25 & 6.04 & \\
\hline & Moss & & 2.5 & 2.5 & 0 & 0 & 0 & 0 & 0 & 0 & 0 & 0 & 0.5 & 1.05 & \\
\hline & & Total Live & 72.5 & 82.5 & 85 & 62.5 & 95 & 70 & 92.5 & 123 & 137.5 & 92.5 & 61.5 & & \\
\hline
\end{tabular}


Table 28. Continued.

\begin{tabular}{|c|c|c|c|c|c|c|c|c|c|c|c|c|c|c|c|}
\hline & & Frame \# & 1 & 2 & 3 & 4 & 5 & 6 & 7 & 8 & 9 & 10 & & & \\
\hline $\begin{array}{c}\text { Transect } \\
I^{*}\end{array}$ & $\begin{array}{l}\text { Common } \\
\text { Name }\end{array}$ & Species Name & \begin{tabular}{|c|} 
Mid \\
point
\end{tabular} & $\begin{array}{l}\text { Mid } \\
\text { point }\end{array}$ & $\begin{array}{c}\text { Mid } \\
\text { point }\end{array}$ & $\begin{array}{c}\text { Mid } \\
\text { point }\end{array}$ & $\begin{array}{c}\text { Mid } \\
\text { point }\end{array}$ & $\begin{array}{c}\text { Mid } \\
\text { point }\end{array}$ & $\begin{array}{l}\text { Mid } \\
\text { point }\end{array}$ & $\begin{array}{l}\text { Mid } \\
\text { point }\end{array}$ & $\begin{array}{l}\text { Mid } \\
\text { point }\end{array}$ & \begin{tabular}{|c|} 
Mid \\
point
\end{tabular} & $\begin{array}{l}\text { Mean } \\
\% \text { cover }\end{array}$ & $\begin{array}{l}\text { Standard } \\
\text { Deviation }\end{array}$ & Frequency \\
\hline \multirow[t]{11}{*}{$\begin{array}{c}\text { GR-SB- } \\
\text { M-02 }\end{array}$} & Red top & Agrostis alba & 15 & 15 & 15 & 0 & 37.5 & 2.5 & 15 & 37.5 & 37.5 & 2.5 & 17.75 & 14.83 & 100 \\
\hline & Idaho fescue & $\begin{array}{c}\text { Festuca } \\
\text { idahoensis }\end{array}$ & 37.5 & 15 & 15 & 2.5 & 2.5 & 15 & 15 & 15 & 15 & 15 & 14.75 & 9.53 & 100 \\
\hline & $\begin{array}{l}\text { Kentucky } \\
\text { bluegrass }\end{array}$ & Poa pratensis & 15 & 0 & 0 & 0 & 0 & 0 & 0 & 0 & 0 & 2.5 & 1.75 & 4.72 & 20 \\
\hline & $\begin{array}{c}\text { Tufted } \\
\text { hairgrass }\end{array}$ & $\begin{array}{c}\text { Deschampsia } \\
\text { caespitosa }\end{array}$ & 2.5 & 0 & 0 & 0 & 0 & 2.5 & 0 & 0 & 0 & 0 & 0.5 & 1.05 & 20 \\
\hline & $\begin{array}{l}\text { Nebraska } \\
\text { sedge }\end{array}$ & $\begin{array}{c}\text { Carex } \\
\text { nebrascensis }\end{array}$ & 2.5 & 0 & 0 & 15 & 0 & 0 & 0 & 0 & 0 & 0 & 1.75 & 4.72 & 20 \\
\hline & $\begin{array}{c}\text { Thickspike } \\
\text { wheatgrass }\end{array}$ & $\begin{array}{c}\text { Agropyron } \\
\text { dasystachyum }\end{array}$ & 2.5 & 15 & 2.5 & 0 & 0 & 0 & 0 & 0 & 0 & 2.5 & 2.25 & 4.63 & 40 \\
\hline & Toad rush & Juncus bufonius & 0 & 2.5 & 0 & 0 & 0 & 0 & 2.5 & 0 & 0 & 0 & 0.5 & 1.05 & 20 \\
\hline & Timothy & Phleum pratense & 0 & 2.5 & 0 & 0 & 0 & 0 & 0 & 0 & 0 & 0 & 0.25 & 0.79 & 10 \\
\hline & Alfalfa & Medicago sativa & 0 & 0 & 62.5 & 62.5 & 62.5 & 85 & 37.5 & 15 & 2.5 & 62.5 & 39 & 32.11 & 80 \\
\hline & Ryegrass & Lolium perenne & 0 & 0 & 2.5 & 0 & 2.5 & 0 & 0 & 0 & 0 & 0 & 0.5 & 1.05 & 20 \\
\hline & $\begin{array}{c}\text { Fowl } \\
\text { mannegrass }\end{array}$ & Glyceria striata & 0 & 0 & 0 & 0 & 0 & 37.5 & 0 & 0 & 0 & 0 & 3.75 & 11.86 & 10 \\
\hline
\end{tabular}


Table 28. Continued.

\begin{tabular}{|c|c|c|c|c|c|c|c|c|c|c|c|c|c|c|c|}
\hline & & Frame \# & 1 & 2 & 3 & 4 & 5 & 6 & 7 & 8 & 9 & 10 & & & \\
\hline \multirow[t]{11}{*}{$\begin{array}{c}\text { Transect } \\
I^{*}\end{array}$} & $\begin{array}{l}\text { Common } \\
\text { Name }\end{array}$ & Species Name & $\begin{array}{l}\text { Mid } \\
\text { point }\end{array}$ & $\begin{array}{l}\text { Mid } \\
\text { point }\end{array}$ & $\begin{array}{c}\text { Mid } \\
\text { point }\end{array}$ & $\begin{array}{c}\text { Mid } \\
\text { point }\end{array}$ & $\begin{array}{l}\text { Mid } \\
\text { point }\end{array}$ & $\begin{array}{c}\text { Mid } \\
\text { point }\end{array}$ & $\begin{array}{l}\text { Mid } \\
\text { point }\end{array}$ & $\begin{array}{c}\text { Mid } \\
\text { point }\end{array}$ & $\begin{array}{l}\text { Mid } \\
\text { point }\end{array}$ & \begin{tabular}{|c|} 
Mid \\
point
\end{tabular} & $\begin{array}{l}\text { Mean } \\
\% \text { cover }\end{array}$ & $\begin{array}{l}\text { Standard } \\
\text { Deviation }\end{array}$ & Frequency \\
\hline & $\begin{array}{l}\text { Cudweed } \\
\text { sagewort }\end{array}$ & $\begin{array}{c}\text { Artemisia } \\
\text { Iudoviciana }\end{array}$ & 0 & 0 & 0 & 0 & 0 & 0 & 2.5 & 0 & 0 & 0 & 0.25 & 0.79 & 10 \\
\hline & Yarrow & $\begin{array}{c}\text { Achillea } \\
\text { millefolium }\end{array}$ & 15 & 15 & 15 & 15 & 15 & 15 & 37.5 & 37.5 & 2.5 & 15 & 18.25 & 10.87 & 100 \\
\hline & $\begin{array}{c}\text { Dwarf } \\
\text { fireweed }\end{array}$ & $\begin{array}{l}\text { Epilobium } \\
\text { latifolium }\end{array}$ & 0 & 0 & 2.5 & 2.5 & 0 & 0 & 0 & 0 & 2.5 & 2.5 & 1 & 1.29 & 40 \\
\hline & $\begin{array}{c}\text { Sulfur } \\
\text { cinquefoil }\end{array}$ & Potentilla recta & 0 & 0 & 0 & 0 & 0 & 0 & 2.5 & 0 & 0 & 0 & 0.25 & 0.79 & 10 \\
\hline & $\begin{array}{c}\text { Slender } \\
\text { wheatgrass }\end{array}$ & $\begin{array}{l}\text { Agropyron } \\
\text { trachycaulum }\end{array}$ & 0 & 0 & 0 & 0 & 0 & 0 & 0 & 0 & 2.5 & 0 & 0.25 & 0.79 & 10 \\
\hline & $\begin{array}{c}\text { Unidentified } \\
\text { forb \#4 }\end{array}$ & & 0 & 0 & 0 & 0 & 0 & 0 & 0 & 0 & 2.5 & 0 & 0.25 & 0.79 & 10 \\
\hline & Bare ground & & 2.5 & 15 & 2.5 & 15 & 15 & 2.5 & 15 & 15 & 37.5 & 15 & 13.5 & 10.29 & \\
\hline & Rock & & 15 & 37.5 & 15 & 2.5 & 15 & 15 & 15 & 37.5 & 15 & 37.5 & 20.5 & 12.35 & \\
\hline & Litter & & 2.5 & 2.5 & 2.5 & 2.5 & 2.5 & 2.5 & 2.5 & 2.5 & 2.5 & 2.5 & 2.5 & 0.00 & \\
\hline & & Total Live & 90 & 65 & 115 & 97.5 & 120 & 158 & 113 & 105 & 65 & 103 & 103 & & \\
\hline \multirow[t]{2}{*}{$\begin{array}{c}\text { GR-SB- } \\
\text { M-03 }\end{array}$} & Red top & Agrostis alba & 37.5 & 85 & 62.5 & 37.5 & 37.5 & 62.5 & 62.5 & 37.5 & 37.5 & 37.5 & 49.75 & 17.10 & 100 \\
\hline & $\begin{array}{l}\text { Idaho } \\
\text { fescue }\end{array}$ & $\begin{array}{c}\text { Festuca } \\
\text { idahoensis }\end{array}$ & 15 & 0 & 15 & 15 & 15 & 0 & 15 & 2.5 & 37.5 & 15 & 13 & 10.92 & 80 \\
\hline
\end{tabular}


Table 28. Continued.

\begin{tabular}{|c|c|c|c|c|c|c|c|c|c|c|c|c|c|c|c|}
\hline & & Frame \# & 1 & 2 & 3 & 4 & 5 & 6 & 7 & 8 & 9 & 10 & & & \\
\hline \multirow[t]{13}{*}{$\begin{array}{c}\text { Transect } \\
\text { ID* }^{*}\end{array}$} & $\begin{array}{l}\text { Common } \\
\text { Name }\end{array}$ & Species Name & $\begin{array}{l}\text { Mid } \\
\text { point }\end{array}$ & $\begin{array}{l}\text { Mid } \\
\text { point }\end{array}$ & $\begin{array}{c}\text { Mid } \\
\text { point }\end{array}$ & $\begin{array}{c}\text { Mid } \\
\text { point }\end{array}$ & $\begin{array}{l}\text { Mid } \\
\text { point }\end{array}$ & $\begin{array}{c}\text { Mid } \\
\text { point }\end{array}$ & $\begin{array}{c}\text { Mid } \\
\text { point }\end{array}$ & $\begin{array}{c}\text { Mid } \\
\text { point }\end{array}$ & $\begin{array}{l}\text { Mid } \\
\text { point }\end{array}$ & $\begin{array}{l}\text { Mid } \\
\text { point }\end{array}$ & $\begin{array}{c}\text { Mean } \\
\% \text { cover }\end{array}$ & $\begin{array}{l}\text { Standard } \\
\text { Deviation }\end{array}$ & Frequency \\
\hline & $\begin{array}{c}\text { Smooth } \\
\text { scouringrush }\end{array}$ & $\begin{array}{l}\text { Equisetum } \\
\text { laevigatum }\end{array}$ & 0 & 15 & 0 & 2.5 & 0 & 0 & 0 & 0 & 0 & 2.5 & 2 & 4.68 & 30 \\
\hline & $\begin{array}{c}\text { Thickspike } \\
\text { wheatgrass }\end{array}$ & $\begin{array}{c}\text { Agropyron } \\
\text { dasystachyum }\end{array}$ & 0 & 2.5 & 0 & 0 & 0 & 0 & 0 & 0 & 0 & 0 & 0.25 & 0.79 & 10 \\
\hline & Timothy & Phleum pratense & 0 & 0 & 0 & 0 & 0 & 0 & 0 & 2.5 & 0 & 15 & 1.75 & 4.72 & 20 \\
\hline & Red clover & $\begin{array}{l}\text { Trifolium } \\
\text { pratense }\end{array}$ & 0 & 0 & 0 & 0 & 0 & 0 & 15 & 0 & 0 & 0 & 1.5 & 4.74 & 10 \\
\hline & Yarrow & $\begin{array}{c}\text { Achillea } \\
\text { millefolium }\end{array}$ & 0 & 0 & 0 & 0 & 15 & 0 & 37.5 & 0 & 0 & 0 & 5.25 & 12.27 & 20 \\
\hline & $\begin{array}{l}\text { Dwarf } \\
\text { fireweed }\end{array}$ & $\begin{array}{l}\text { Epilobium } \\
\text { latifolium }\end{array}$ & 0 & 0 & 0 & 0 & 2.5 & 0 & 0 & 0 & 0 & 0 & 0.25 & 0.79 & 10 \\
\hline & $\begin{array}{c}\text { Unidentified } \\
\text { forb \#3 }\end{array}$ & & 0 & 0 & 0 & 0 & 0 & 0 & 2.5 & 0 & 0 & 2.5 & 0.5 & 1.05 & 20 \\
\hline & Moss & & 15 & 2.5 & 2.5 & 2.5 & 0 & 0 & 2.5 & 0 & 2.5 & 0 & 2.75 & 4.48 & 60 \\
\hline & Bare ground & & 62.5 & 15 & 37.5 & 62.5 & 62.5 & 62.5 & 37.5 & 62.5 & 62.5 & 62.5 & 52.75 & 16.85 & \\
\hline & Rock & & 15 & 15 & 15 & 15 & 15 & 15 & 2.5 & 15 & 15 & 15 & 13.75 & 3.95 & \\
\hline & Litter & & 2.5 & 2.5 & 2.5 & 2.5 & 2.5 & 2.5 & 2.5 & 2.5 & 2.5 & 2.5 & 2.5 & 0.00 & \\
\hline & & Total Live & 67.5 & 105 & 80 & 57.5 & 70 & 62.5 & 135 & 42.5 & 77.5 & 72.5 & 74.25 & & \\
\hline
\end{tabular}


Table 28. Continued.

\begin{tabular}{|c|c|c|c|c|c|c|c|c|c|c|c|c|c|c|c|}
\hline & & Frame \# & 1 & 2 & 3 & 4 & 5 & 6 & 7 & 8 & 9 & 10 & & & \\
\hline $\begin{array}{c}\text { Transect } \\
I^{*}\end{array}$ & $\begin{array}{l}\text { Common } \\
\text { Name }\end{array}$ & Species Name & \begin{tabular}{|c|} 
Mid \\
point
\end{tabular} & $\begin{array}{l}\text { Mid } \\
\text { point }\end{array}$ & $\begin{array}{c}\text { Mid } \\
\text { point }\end{array}$ & $\begin{array}{l}\text { Mid } \\
\text { point }\end{array}$ & $\begin{array}{c}\text { Mid } \\
\text { point }\end{array}$ & $\begin{array}{c}\text { Mid } \\
\text { point }\end{array}$ & $\begin{array}{c}\text { Mid } \\
\text { point }\end{array}$ & $\begin{array}{c}\text { Mid } \\
\text { point }\end{array}$ & $\begin{array}{l}\text { Mid } \\
\text { point }\end{array}$ & \begin{tabular}{|c|} 
Mid \\
point
\end{tabular} & $\begin{array}{l}\text { Mean } \\
\% \text { cover }\end{array}$ & $\begin{array}{l}\text { Standard } \\
\text { Deviation }\end{array}$ & Frequency \\
\hline \multirow[t]{7}{*}{$\begin{array}{l}\text { GR-SB- } \\
\mathrm{P}-01 a, b\end{array}$} & Red top & Agrostis alba & 0 & 2.5 & 0 & 0 & 0 & 0 & 0 & 2.5 & 0 & 0 & 0.5 & 1.05 & 20 \\
\hline & Idaho fescue & $\begin{array}{c}\text { Festuca } \\
\text { idahoensis }\end{array}$ & 0 & 0 & 0 & 2.5 & 0 & 0 & 0 & 0 & 0 & 0 & 0.25 & 0.79 & 10 \\
\hline & Moss & & 0 & 0 & 15 & 15 & 2.5 & 2.5 & 15 & 2.5 & 2.5 & 2.5 & 5.75 & 6.46 & 80 \\
\hline & Bare ground & & 85 & 85 & 97.5 & 85 & 97.5 & 85 & 62.5 & 97.5 & 37.5 & 15 & 74.75 & 28.05 & \\
\hline & Rock & & 15 & 15 & 2.5 & 2.5 & 2.5 & 2.5 & 2.5 & 2.5 & 2.5 & 15 & 6.25 & 6.04 & \\
\hline & Litter & & 15 & 2.5 & 2.5 & 0 & 2.5 & 37.5 & 15 & 2.5 & 62.5 & 37.5 & 17.75 & 21.20 & \\
\hline & & Total Live & 0 & 2.5 & 15 & 17.5 & 2.5 & 2.5 & 15 & 5 & 2.5 & 2.5 & 6.5 & & \\
\hline \multirow[t]{9}{*}{$\begin{array}{c}\text { GR-SB- } \\
\text { P-02 }\end{array}$} & Red top & Agrostis alba & 15 & 37.5 & 2.5 & 15 & 37.5 & 0 & 62.5 & 62.5 & 15 & 2.5 & 25 & 23.72 & 90 \\
\hline & $\begin{array}{l}\text { Idaho } \\
\text { fescue }\end{array}$ & $\begin{array}{c}\text { Festuca } \\
\text { idahoensis }\end{array}$ & 0 & 15 & 2.5 & 0 & 0 & 0 & 0 & 0 & 0 & 2.5 & 2 & 4.68 & 30 \\
\hline & Baltic rush & Juncus balticus & 0 & 0 & 0 & 0 & 15 & 0 & 0 & 0 & 0 & 0 & 1.5 & 4.74 & 10 \\
\hline & $\begin{array}{c}\text { Tufted } \\
\text { hairgrass }\end{array}$ & $\begin{array}{c}\text { Deschampsia } \\
\text { caespitosa }\end{array}$ & 0 & 0 & 0 & 0 & 0 & 0 & 0 & 0 & 15 & 0 & 1.5 & 4.74 & 10 \\
\hline & Sedge & Carex spp. & 0 & 0 & 0 & 0 & 0 & 0 & 0 & 0 & 0 & 15 & 1.5 & 4.74 & 10 \\
\hline & Bare ground & & 62.5 & 37.5 & 15 & 15 & 62.5 & 37.5 & 15 & 15 & 2.5 & 62.5 & 32.5 & 23.27 & \\
\hline & Rock & & 2.5 & 2.5 & 2.5 & 2.5 & 15 & 15 & 15 & 15 & 2.5 & 2.5 & 7.5 & 6.45 & \\
\hline & Litter & & 15 & 15 & 62.5 & 62.5 & 2.5 & 37.5 & 15 & 2.5 & 67.5 & 2.5 & 28.25 & 26.85 & \\
\hline & & Total Live & 15 & 52.5 & 5 & 15 & 52.5 & 0 & 62.5 & 62.5 & 30 & 20 & 31.5 & & \\
\hline
\end{tabular}


Table 28. Continued.

\begin{tabular}{|c|c|c|c|c|c|c|c|c|c|c|c|c|c|c|c|}
\hline & & Frame \# & 1 & 2 & 3 & 4 & 5 & 6 & 7 & 8 & 9 & 10 & & & \\
\hline $\begin{array}{c}\text { Transect } \\
\text { ID* }\end{array}$ & $\begin{array}{l}\text { Common } \\
\text { Name }\end{array}$ & Species Name & $\begin{array}{c}\text { Mid } \\
\text { point }\end{array}$ & $\begin{array}{l}\text { Mid } \\
\text { point }\end{array}$ & $\begin{array}{c}\text { Mid } \\
\text { point }\end{array}$ & \begin{tabular}{|c|} 
Mid \\
point
\end{tabular} & $\begin{array}{l}\text { Mid } \\
\text { point }\end{array}$ & $\begin{array}{l}\text { Mid } \\
\text { point }\end{array}$ & $\begin{array}{c}\text { Mid } \\
\text { point }\end{array}$ & $\begin{array}{l}\text { Mid } \\
\text { point }\end{array}$ & $\begin{array}{l}\text { Mid } \\
\text { point }\end{array}$ & \begin{tabular}{|c|} 
Mid \\
point
\end{tabular} & $\begin{array}{c}\text { Mean } \\
\% \text { cover }\end{array}$ & $\begin{array}{l}\text { Standard } \\
\text { Deviation }\end{array}$ & Frequency \\
\hline \multirow[t]{10}{*}{$\begin{array}{c}\text { GR-SB- } \\
\text { P-03 }\end{array}$} & Red top & Agrostis alba & 0 & 0 & 0 & 0 & 0 & 0 & 15 & 62.5 & 0 & 0 & 7.75 & 19.81 & 20 \\
\hline & Idaho fescue & $\begin{array}{c}\text { Festuca } \\
\text { idahoensis }\end{array}$ & 0 & 0 & 0 & 0 & 0 & 0 & 2.5 & 0 & 0 & 0 & 0.25 & 0.79 & 10 \\
\hline & $\begin{array}{c}\text { Tufted } \\
\text { hairgrass }\end{array}$ & $\begin{array}{c}\text { Deschampsia } \\
\text { caespitosa }\end{array}$ & 0 & 0 & 0 & 0 & 0 & 0 & 15 & 15 & 0 & 0 & 3 & 6.32 & 20 \\
\hline & $\begin{array}{l}\text { Nebraska } \\
\text { sedge }\end{array}$ & $\begin{array}{c}\text { Carex } \\
\text { nebrascensis }\end{array}$ & 0 & 0 & 0 & 0 & 0 & 0 & 0 & 15 & 0 & 2.5 & 1.75 & 4.72 & 20 \\
\hline & $\begin{array}{c}\text { Smooth } \\
\text { scouringrush }\end{array}$ & $\begin{array}{l}\text { Equisetum } \\
\text { laevigatum }\end{array}$ & 0 & 0 & 0 & 0 & 0 & 0 & 0 & 15 & 15 & 0 & 3 & 6.32 & 20 \\
\hline & Moss & & 0 & 2.5 & 0 & 2.5 & 0 & 2.5 & 0 & 0 & 2.5 & 15 & 2.5 & 4.56 & 50 \\
\hline & Bare ground & & 97.5 & 85 & 97.5 & 97.5 & 97.5 & 97.5 & 85 & 15 & 85 & 97.5 & 85.5 & 25.46 & \\
\hline & Rock & & 15 & 2.5 & 2.5 & 2.5 & 15 & 15 & 2.5 & 2.5 & 2.5 & 2.5 & 6.25 & 6.04 & \\
\hline & Litter & & 2.5 & 15 & 15 & 2.5 & 2.5 & 2.5 & 15 & 2.5 & 2.5 & 15 & 7.5 & 6.45 & \\
\hline & & Total Live & 0 & 2.5 & 0 & 2.5 & 0 & 2.5 & 32.5 & 108 & 17.5 & 17.5 & 15.75 & & \\
\hline
\end{tabular}


Table 28. Continued.

\begin{tabular}{|c|c|c|c|c|c|c|c|c|c|c|c|c|c|c|c|}
\hline & & Frame \# & 1 & 2 & 3 & 4 & 5 & 6 & 7 & 8 & 9 & 10 & & & \\
\hline $\begin{array}{c}\text { Transect } \\
I^{*}\end{array}$ & $\begin{array}{l}\text { Common } \\
\text { Name }\end{array}$ & Species Name & $\begin{array}{l}\text { Mid } \\
\text { point }\end{array}$ & \begin{tabular}{|} 
Mid \\
point
\end{tabular} & \begin{tabular}{|c|} 
Mid \\
point
\end{tabular} & $\begin{array}{c}\text { Mid } \\
\text { point }\end{array}$ & $\begin{array}{l}\text { Mid } \\
\text { point }\end{array}$ & $\begin{array}{l}\text { Mid } \\
\text { point }\end{array}$ & $\begin{array}{l}\text { Mid } \\
\text { point }\end{array}$ & $\begin{array}{c}\text { Mid } \\
\text { point }\end{array}$ & $\begin{array}{c}\text { Mid } \\
\text { point }\end{array}$ & $\begin{array}{l}\text { Mid } \\
\text { point }\end{array}$ & $\begin{array}{c}\text { Mean } \\
\% \text { cover }\end{array}$ & $\begin{array}{l}\text { Standard } \\
\text { Deviation }\end{array}$ & Frequency \\
\hline \multirow[t]{14}{*}{$\begin{array}{c}\text { GR-OV- } \\
\text { G-01 }\end{array}$} & Red top & Agrostis alba & 62.5 & 37.5 & 15 & 0 & 0 & 0 & 15 & 2.5 & 0 & 0 & 13.25 & 21.12 & 50 \\
\hline & Idaho fescue & $\begin{array}{c}\text { Festuca } \\
\text { idahoensis }\end{array}$ & 15 & 37.5 & 15 & 15 & 15 & 62.5 & 15 & 15 & 15 & 2.5 & 20.75 & 16.96 & 100 \\
\hline & Baltic rush & Juncus balticus & 0 & 15 & 0 & 15 & 0 & 0 & 2.5 & 0 & 0 & 0 & 3.25 & 6.24 & 30 \\
\hline & Canada & Poa compressa & 0 & 15 & 15 & 15 & 37.5 & 15 & 37.5 & 62.5 & 62.5 & 62.5 & 32.25 & 23.64 & 90 \\
\hline & Ryegrass & Lolium perenne & 0 & 2.5 & 0 & 0 & 0 & 0 & 0 & 0 & 0 & 0 & 0.25 & 0.79 & 10 \\
\hline & Yarrow & $\begin{array}{l}\text { Achillea } \\
\text { millefolium }\end{array}$ & 2.5 & 0 & 2.5 & 2.5 & 37.5 & 37.5 & 37.5 & 62.5 & 62.5 & 37.5 & 28.25 & 24.67 & 90 \\
\hline & $\begin{array}{c}\text { Sulfur } \\
\text { cinquefoil }\end{array}$ & Potentilla recta & 0 & 0 & 0 & 0 & 2.5 & 2.5 & 2.5 & 15 & 0 & 2.5 & 2.5 & 4.56 & 50 \\
\hline & $\begin{array}{c}\text { Dwarf } \\
\text { fireweed }\end{array}$ & $\begin{array}{l}\text { Epilobium } \\
\text { latifolium }\end{array}$ & 0 & 0 & 0 & 0 & 0 & 2.5 & 0 & 0 & 0 & 0 & 0.25 & 0.79 & 10 \\
\hline & $\begin{array}{c}\text { Unidentified } \\
\text { forb \#5 }\end{array}$ & & 0 & 0 & 0 & 0 & 0 & 0 & 2.5 & 0 & 0 & 0 & 0.25 & 0.79 & 10 \\
\hline & Alfalfa & Medicago sativa & 0 & 0 & 0 & 0 & 0 & 0 & 0 & 0 & 2.5 & 0 & 0.25 & 0.79 & 10 \\
\hline & Bare ground & & 2.5 & 2.5 & 2.5 & 2.5 & 2.5 & 2.5 & 2.5 & 2.5 & 2.5 & 2.5 & 2.5 & 0.00 & \\
\hline & Rock & & 2.5 & 2.5 & 2.5 & 2.5 & 2.5 & 2.5 & 2.5 & 2.5 & 2.5 & 2.5 & 2.5 & 0.00 & \\
\hline & Litter & & 62.5 & 85 & 85 & 85 & 37.5 & 37.5 & 37.5 & 15 & 15 & 15 & 47.5 & 29.65 & \\
\hline & & Total Live & 80 & 107.5 & 47.5 & 47.5 & 92.5 & 120 & 113 & 158 & 142.5 & 105 & 101.25 & & \\
\hline
\end{tabular}


Table 28. Continued.

\begin{tabular}{|c|c|c|c|c|c|c|c|c|c|c|c|c|c|c|c|}
\hline & & Frame \# & 1 & 2 & 3 & 4 & 5 & 6 & 7 & 8 & 9 & 10 & & & \\
\hline $\begin{array}{c}\text { Transect } \\
\text { ID* }\end{array}$ & $\begin{array}{l}\text { Common } \\
\text { Name }\end{array}$ & Species Name & $\begin{array}{c}\text { Mid } \\
\text { point }\end{array}$ & $\begin{array}{l}\text { Mid } \\
\text { point }\end{array}$ & $\begin{array}{c}\text { Mid } \\
\text { point }\end{array}$ & $\begin{array}{l}\text { Mid } \\
\text { point }\end{array}$ & \begin{tabular}{|c|} 
Mid \\
point
\end{tabular} & \begin{tabular}{|c|} 
Mid \\
point
\end{tabular} & $\begin{array}{l}\text { Mid } \\
\text { point }\end{array}$ & $\begin{array}{c}\text { Mid } \\
\text { point }\end{array}$ & $\begin{array}{l}\text { Mid } \\
\text { point }\end{array}$ & $\begin{array}{l}\text { Mid } \\
\text { point }\end{array}$ & $\begin{array}{c}\text { Mean } \\
\% \text { cover }\end{array}$ & $\begin{array}{l}\text { Standard } \\
\text { Deviation }\end{array}$ & Frequency \\
\hline \multirow[t]{11}{*}{$\begin{array}{c}\text { GR-OV- } \\
\text { G-02 }\end{array}$} & Red top & Agrostis alba & 85 & 85 & 15 & 15 & 2.5 & 92.5 & 85 & 92.5 & 2.5 & 62.5 & 53.75 & 39.81 & 100 \\
\hline & Idaho fescue & $\begin{array}{c}\text { Festuca } \\
\text { idahoensis }\end{array}$ & 37.5 & 37.5 & 62.5 & 62.5 & 62.5 & 0 & 0 & 0 & 32.5 & 37.5 & 33.25 & 25.69 & 70 \\
\hline & $\begin{array}{c}\text { Unidentified } \\
\text { grass \#2 }\end{array}$ & & 0 & 0 & 0 & 0 & 2.5 & 0 & 0 & 0 & 0 & 0 & 0.25 & 0.79 & 10 \\
\hline & Yarrow & $\begin{array}{c}\text { Achillea } \\
\text { millefolium }\end{array}$ & 15 & 37.5 & 15 & 37.5 & 0 & 0 & 15 & 37.5 & 15 & 37.5 & 21 & 15.33 & 80 \\
\hline & $\begin{array}{c}\text { Unidentified } \\
\text { forb \#2 }\end{array}$ & & 2.5 & 0 & 0 & 0 & 0 & 0 & 0 & 0 & 0 & 0 & 0.25 & 0.79 & 10 \\
\hline & $\begin{array}{c}\text { Unidentified } \\
\text { forb } \# 3\end{array}$ & & 0 & 0 & 0 & 0 & 0 & 0 & 0 & 0 & 0 & 2.5 & 0.25 & 0.79 & 10 \\
\hline & $\begin{array}{c}\text { Unidentified } \\
\text { forb \#4 }\end{array}$ & & 0 & 2.5 & 0 & 0 & 0 & 0 & 0 & 0 & 2.5 & 2.5 & 0.75 & 1.21 & 30 \\
\hline & Bare ground & & 2.5 & 2.5 & 15 & 2.5 & 2.5 & 15 & 2.5 & 15 & 15 & 2.5 & 7.5 & 6.45 & \\
\hline & Rock & & 2.5 & 2.5 & 15 & 2.5 & 2.5 & 2.5 & 2.5 & 2.5 & 2.5 & 2.5 & 3.75 & 3.95 & \\
\hline & Litter & & 15 & 15 & 37.5 & 37.5 & 2.5 & 37.5 & 15 & 37.5 & 2.5 & 15 & 21.5 & 14.59 & \\
\hline & & Total Live & 140 & 162.5 & 92.5 & 115 & 67.5 & 92.5 & 100 & 130 & 52.5 & 143 & 109.5 & & \\
\hline
\end{tabular}


Table 28. Continued.

\begin{tabular}{|c|c|c|c|c|c|c|c|c|c|c|c|c|c|c|c|}
\hline & & Frame \# & 1 & 2 & 3 & 4 & 5 & 6 & 7 & 8 & 9 & 10 & & & \\
\hline $\begin{array}{c}\text { Transect } \\
\text { ID* }\end{array}$ & $\begin{array}{l}\text { Common } \\
\text { Name }\end{array}$ & Species Name & $\begin{array}{c}\text { Mid } \\
\text { point }\end{array}$ & $\begin{array}{c}\text { Mid } \\
\text { point }\end{array}$ & $\begin{array}{c}\text { Mid } \\
\text { point }\end{array}$ & $\begin{array}{c}\text { Mid } \\
\text { point }\end{array}$ & $\begin{array}{c}\text { Mid } \\
\text { point }\end{array}$ & $\begin{array}{c}\text { Mid } \\
\text { point }\end{array}$ & $\begin{array}{l}\text { Mid } \\
\text { point }\end{array}$ & $\begin{array}{c}\text { Mid } \\
\text { point }\end{array}$ & $\begin{array}{l}\text { Mid } \\
\text { point }\end{array}$ & $\begin{array}{l}\text { Mid } \\
\text { point }\end{array}$ & $\begin{array}{c}\text { Mean } \\
\% \text { cover }\end{array}$ & $\begin{array}{l}\text { Standard } \\
\text { Deviation }\end{array}$ & Frequency \\
\hline \multirow[t]{12}{*}{$\begin{array}{c}\text { GR-OV- } \\
\text { G-03 }\end{array}$} & Red top & Agrostis alba & 85 & 37.5 & 2.5 & 37.5 & 62.5 & 62.5 & 62.5 & 0 & 2.5 & 15 & 36.75 & 30.71 & 90 \\
\hline & Idaho fescue & $\begin{array}{c}\text { Festuca } \\
\text { idahoensis }\end{array}$ & 2.5 & 15 & 0 & 0 & 0 & 2.5 & 15 & 37.5 & 15 & 62.5 & 15 & 20.41 & 70 \\
\hline & $\begin{array}{c}\text { Slender } \\
\text { wheatgrass }\end{array}$ & $\begin{array}{l}\text { Agropyron } \\
\text { trachycaulum }\end{array}$ & 0 & 0 & 37.5 & 37.5 & 0 & 0 & 0 & 0 & 0 & 0 & 7.5 & 15.81 & 20 \\
\hline & Timothy & Phleum pratense & 0 & 0 & 0 & 0 & 0 & 2.5 & 2.5 & 2.5 & 37.5 & 2.5 & 4.75 & 11.57 & 50 \\
\hline & Yarrow & $\begin{array}{c}\text { Achillea } \\
\text { millefolium }\end{array}$ & 62.5 & 37.5 & 85 & 37.5 & 2.5 & 15 & 37.5 & 62.5 & 37.5 & 15 & 39.25 & 25.20 & 100 \\
\hline & $\begin{array}{c}\text { Rocky } \\
\text { Mountain iris }\end{array}$ & Iris Missouriensis & 0 & 37.5 & 0 & 37.5 & 0 & 0 & 0 & 0 & 0 & 0 & 7.5 & 15.81 & 20 \\
\hline & White clover & Trifolium repens & 2.5 & 0 & 0 & 0 & 0 & 37.5 & 15 & 0 & 0 & 15 & 7 & 12.35 & 40 \\
\hline & Red clover & $\begin{array}{l}\text { Trifolium } \\
\text { pratense }\end{array}$ & 0 & 0 & 0 & 0 & 0 & 0 & 0 & 15 & 0 & 15 & 3 & 6.32 & 20 \\
\hline & Bare ground & & 2.5 & 15 & 2.5 & 15 & 37.5 & 15 & 15 & 37.5 & 37.5 & 15 & 19.25 & 13.54 & \\
\hline & Rock & & 2.5 & 2.5 & 2.5 & 2.5 & 2.5 & 2.5 & 2.5 & 2.5 & 2.5 & 2.5 & 2.5 & 0.00 & \\
\hline & Litter & & 15 & 15 & 37.5 & 37.5 & 15 & 2.5 & 2.5 & 15 & 2.5 & 15 & 15.75 & 12.80 & \\
\hline & & Total Live & 152.5 & 127.5 & 125 & 150 & 65 & 120 & 133 & 118 & 92.5 & 125 & 120.75 & & \\
\hline
\end{tabular}


Table 28. Continued.

\begin{tabular}{|c|c|c|c|c|c|c|c|c|c|c|c|c|c|c|c|}
\hline & & Frame \# & 1 & 2 & 3 & 4 & 5 & 6 & 7 & 8 & 9 & 10 & & & \\
\hline $\begin{array}{c}\text { Transect } \\
I^{*}\end{array}$ & $\begin{array}{l}\text { Common } \\
\text { Name }\end{array}$ & Species Name & $\begin{array}{c}\text { Mid } \\
\text { point }\end{array}$ & $\begin{array}{l}\text { Mid } \\
\text { point }\end{array}$ & $\begin{array}{c}\text { Mid } \\
\text { point }\end{array}$ & \begin{tabular}{|c|} 
Mid \\
point
\end{tabular} & \begin{tabular}{|c|} 
Mid \\
point
\end{tabular} & \begin{tabular}{|c|} 
Mid \\
point
\end{tabular} & $\begin{array}{c}\text { Mid } \\
\text { point }\end{array}$ & $\begin{array}{c}\text { Mid } \\
\text { point }\end{array}$ & $\begin{array}{l}\text { Mid } \\
\text { point }\end{array}$ & \begin{tabular}{|c|} 
Mid \\
point
\end{tabular} & $\begin{array}{c}\text { Mean } \\
\% \text { cover }\end{array}$ & $\begin{array}{l}\text { Standard } \\
\text { Deviation }\end{array}$ & Frequency \\
\hline \multirow[t]{8}{*}{$\begin{array}{c}\text { GR-OV- } \\
\text { M-01 }\end{array}$} & Idaho fescue & $\begin{array}{c}\text { Festuca } \\
\text { idahoensis }\end{array}$ & 62.5 & 15 & 37.5 & 15 & 37.5 & 62.5 & 37.5 & 37.5 & 15 & 37.5 & 35.75 & 17.44 & 100 \\
\hline & $\begin{array}{l}\text { Cudweed } \\
\text { sagewort }\end{array}$ & $\begin{array}{c}\text { Artemisia } \\
\text { Iudoviciana }\end{array}$ & 0 & 0 & 0 & 0 & 0 & 0 & 2.5 & 0 & 0 & 0 & 0.25 & 0.79 & 10 \\
\hline & Alfalfa & Medicago sativa & 0 & 0 & 0 & 0 & 0 & 0 & 0 & 2.5 & 0 & 0 & 0.25 & 0.79 & 10 \\
\hline & Yarrow & $\begin{array}{c}\text { Achillea } \\
\text { millefolium }\end{array}$ & 15 & 15 & 15 & 15 & 15 & 15 & 37.5 & 37.5 & 37.5 & 15 & 21.75 & 10.87 & 100 \\
\hline & Bare ground & & 37.5 & 85 & 62.5 & 62.5 & 62.5 & 37.5 & 37.5 & 15 & 62.5 & 62.5 & 52.5 & 20.10 & \\
\hline & Rock & & 2.5 & 2.5 & 15 & 37.5 & 15 & 15 & 2.5 & 15 & 15 & 15 & 13.5 & 10.29 & \\
\hline & Litter & & 15 & 15 & 15 & 15 & 2.5 & 2.5 & 15 & 15 & 15 & 2.5 & 11.25 & 6.04 & \\
\hline & & Total Live & 77.5 & 30 & 52.5 & 30 & 52.5 & 77.5 & 77.5 & 77.5 & 52.5 & 52.5 & 58 & & \\
\hline \multirow[t]{5}{*}{$\begin{array}{l}\text { GR-OV- } \\
\text { M-02 }\end{array}$} & $\begin{array}{l}\text { Idaho } \\
\text { fescue }\end{array}$ & $\begin{array}{c}\text { Festuca } \\
\text { idahoensis }\end{array}$ & 37.5 & 37.5 & 37.5 & 37.5 & 62.5 & 37.5 & 37.5 & 15 & 37.5 & 37.5 & 37.75 & 11.21 & 100 \\
\hline & Red top & Agrostis alba & 0 & 0 & 0 & 0 & 0 & 2.5 & 0 & 62.5 & 2.5 & 15 & 8.25 & 19.62 & 40 \\
\hline & $\begin{array}{c}\text { Unidentified } \\
\text { grass \#5 }\end{array}$ & & 0 & 0 & 0 & 0 & 2.5 & 2.5 & 2.5 & 0 & 2.5 & 2.5 & 1.25 & 1.32 & 50 \\
\hline & Yarrow & $\begin{array}{l}\text { Achillea } \\
\text { millefolium }\end{array}$ & 15 & 2.5 & 15 & 2.5 & 37.5 & 15 & 37.5 & 15 & 37.5 & 15 & 19.25 & 13.54 & 100 \\
\hline & $\begin{array}{c}\text { Sulfur } \\
\text { cinquefoil }\end{array}$ & Potentilla recta & 0 & 0 & 0 & 0 & 0 & 0 & 0 & 0 & 2.5 & 2.5 & 0.5 & 1.05 & 20 \\
\hline
\end{tabular}


Table 28. Continued.

\begin{tabular}{|c|c|c|c|c|c|c|c|c|c|c|c|c|c|c|c|}
\hline & & Frame \# & 1 & 2 & 3 & 4 & 5 & 6 & 7 & 8 & 9 & 10 & & & \\
\hline \multirow[t]{5}{*}{$\begin{array}{c}\text { Transect } \\
I^{*}\end{array}$} & $\begin{array}{l}\text { Common } \\
\text { Name }\end{array}$ & Species Name & $\begin{array}{c}\text { Mid } \\
\text { point }\end{array}$ & $\begin{array}{l}\text { Mid } \\
\text { point }\end{array}$ & $\begin{array}{c}\text { Mid } \\
\text { point }\end{array}$ & \begin{tabular}{|c|} 
Mid \\
point
\end{tabular} & \begin{tabular}{|c|} 
Mid \\
point
\end{tabular} & $\begin{array}{c}\text { Mid } \\
\text { point }\end{array}$ & $\begin{array}{c}\text { Mid } \\
\text { point }\end{array}$ & \begin{tabular}{|c|} 
Mid \\
point
\end{tabular} & $\begin{array}{l}\text { Mid } \\
\text { point }\end{array}$ & \begin{tabular}{|c|} 
Mid \\
point
\end{tabular} & $\begin{array}{l}\text { Mean } \\
\% \text { cover }\end{array}$ & $\begin{array}{l}\text { Standard } \\
\text { Deviation }\end{array}$ & Frequency \\
\hline & Bare ground & & 37.5 & 62.5 & 37.5 & 37.5 & 15 & 37.5 & 37.5 & 15 & 15 & 37.5 & 33.25 & 14.77 & \\
\hline & Rock & & 2.5 & 15 & 15 & 2.5 & 2.5 & 2.5 & 2.5 & 2.5 & 2.5 & 2.5 & 5 & 5.27 & \\
\hline & Litter & & 15 & 2.5 & 2.5 & 37.5 & 15 & 2.5 & 15 & 15 & 2.5 & 15 & 12.25 & 10.83 & \\
\hline & & Total Live & 52.5 & 40 & 52.5 & 40 & 103 & 57.5 & 77.5 & 92.5 & 82.5 & 72.5 & 67 & & \\
\hline \multirow[t]{7}{*}{$\begin{array}{l}\text { GR-OV- } \\
\text { M-03 }\end{array}$} & Idaho fescue & $\begin{array}{c}\text { Festuca } \\
\text { idahoensis }\end{array}$ & 37.5 & 2.5 & 2.5 & 15 & 15 & 15 & 15 & 15 & 15 & 37.5 & 17 & 11.95 & 100 \\
\hline & Red top & Agrostis alba & 0 & 62.5 & 15 & 62.5 & 37.5 & 0 & 2.5 & 0 & 37.5 & 0 & 21.75 & 26.09 & 60 \\
\hline & Timothy & Phleum pratense & 0 & 0 & 0 & 0 & 2.5 & 0 & 2.5 & 37.5 & 2.5 & 15 & 6 & 11.97 & 50 \\
\hline & Yarrow & $\begin{array}{c}\text { Achillea } \\
\text { millefolium }\end{array}$ & 15 & 15 & 37.5 & 15 & 2.5 & 15 & 15 & 15 & 15 & 37.5 & 18.25 & 10.87 & 100 \\
\hline & Red clover & $\begin{array}{l}\text { Trifolium } \\
\text { pratense }\end{array}$ & 0 & 2.5 & 0 & 2.5 & 15 & 2.5 & 37.5 & 2.5 & 15 & 15 & 9.25 & 11.79 & 80 \\
\hline & $\begin{array}{c}\text { Unidentified } \\
\text { forb \#5 }\end{array}$ & & 2.5 & 0 & 0 & 0 & 0 & 0 & 0 & 0 & 0 & 0 & 0.25 & 0.79 & 10 \\
\hline & Bare ground & & 85 & 62.5 & 62.5 & 37.5 & 37.5 & 62.5 & 37.5 & 62.5 & 15 & 15 & 47.75 & 22.90 & \\
\hline
\end{tabular}


Table 28. Continued.

\begin{tabular}{|c|c|c|c|c|c|c|c|c|c|c|c|c|c|c|c|}
\hline & & Frame \# & 1 & 2 & 3 & 4 & 5 & 6 & 7 & 8 & 9 & 10 & & & \\
\hline \multirow[t]{4}{*}{$\begin{array}{c}\text { Transect } \\
I^{*}\end{array}$} & $\begin{array}{l}\text { Common } \\
\text { Name }\end{array}$ & Species Name & \begin{tabular}{|c|} 
Mid \\
point
\end{tabular} & $\begin{array}{l}\text { Mid } \\
\text { point }\end{array}$ & $\begin{array}{c}\text { Mid } \\
\text { point }\end{array}$ & \begin{tabular}{|c|} 
Mid \\
point
\end{tabular} & \begin{tabular}{|c|} 
Mid \\
point
\end{tabular} & $\begin{array}{l}\text { Mid } \\
\text { point }\end{array}$ & $\begin{array}{c}\text { Mid } \\
\text { point }\end{array}$ & $\begin{array}{c}\text { Mid } \\
\text { point }\end{array}$ & $\begin{array}{l}\text { Mid } \\
\text { point }\end{array}$ & \begin{tabular}{|c|} 
Mid \\
point
\end{tabular} & $\begin{array}{c}\text { Mean } \\
\% \text { cover }\end{array}$ & $\begin{array}{l}\text { Standard } \\
\text { Deviation }\end{array}$ & Frequency \\
\hline & Rock & & 2.5 & 2.5 & 37.5 & 15 & 2.5 & 15 & 2.5 & 2.5 & 2.5 & 15 & 9.75 & 11.39 & \\
\hline & Litter & & 15 & 15 & 2.5 & 15 & 15 & 15 & 15 & 15 & 15 & 15 & 13.75 & 3.95 & \\
\hline & & Total Live & 55 & 82.5 & 55 & 95 & 72.5 & 32.5 & 72.5 & 70 & 85 & 105 & 72.5 & & \\
\hline \multirow[t]{7}{*}{$\begin{array}{c}\text { GR-OV- } \\
\text { P-01 }\end{array}$} & Red top & Agrostis alba & 15 & 0 & 0 & 0 & 0 & 0 & 0 & 0 & 0 & 0 & 1.5 & 4.74 & 10 \\
\hline & Idaho fescue & $\begin{array}{c}\text { Festuca } \\
\text { idahoensis }\end{array}$ & 2.5 & 0 & 0 & 0 & 15 & 0 & 0 & 0 & 0 & 0 & 1.75 & 4.72 & 25 \\
\hline & Yarrow & $\begin{array}{c}\text { Achillea } \\
\text { millefolium }\end{array}$ & 0 & 0 & 0 & 0 & 2.5 & 0 & 0 & 0 & 0 & 0 & 0.25 & 0.79 & 10 \\
\hline & Bare ground & & 37.5 & 2.5 & 15 & 62.5 & 62.5 & 62.5 & 37.5 & 37.5 & 37.5 & 62.5 & 41.75 & 21.21 & \\
\hline & Rock & & 62.5 & 92.5 & 85 & 37.5 & 15 & 37.5 & 62.5 & 62.5 & 62.5 & 37.5 & 55.5 & 23.68 & \\
\hline & Litter & & 2.5 & 0 & 0 & 0 & 2.5 & 0 & 0 & 15 & 0 & 0 & 2 & 4.68 & \\
\hline & & Total Live & 17.5 & 0 & 0 & 0 & 17.5 & 0 & 0 & 0 & 0 & 0 & 3.5 & & \\
\hline
\end{tabular}


Table 28. Continued.

\begin{tabular}{|c|c|c|c|c|c|c|c|c|c|c|c|c|c|c|c|}
\hline & & Frame \# & 1 & 2 & 3 & 4 & 5 & 6 & 7 & 8 & 9 & 10 & & & \\
\hline $\begin{array}{c}\text { Transect } \\
I^{*}\end{array}$ & $\begin{array}{l}\text { Common } \\
\text { Name }\end{array}$ & Species Name & \begin{tabular}{|c|} 
Mid \\
point
\end{tabular} & $\begin{array}{l}\text { Mid } \\
\text { point }\end{array}$ & $\begin{array}{c}\text { Mid } \\
\text { point }\end{array}$ & $\begin{array}{c}\text { Mid } \\
\text { point }\end{array}$ & $\begin{array}{c}\text { Mid } \\
\text { point }\end{array}$ & \begin{tabular}{|c|} 
Mid \\
point
\end{tabular} & $\begin{array}{c}\text { Mid } \\
\text { point }\end{array}$ & $\begin{array}{l}\text { Mid } \\
\text { point }\end{array}$ & $\begin{array}{l}\text { Mid } \\
\text { point }\end{array}$ & \begin{tabular}{|c|} 
Mid \\
point
\end{tabular} & $\begin{array}{c}\text { Mean } \\
\% \text { cover }\end{array}$ & $\begin{array}{l}\text { Standard } \\
\text { Deviation }\end{array}$ & Frequency \\
\hline \multirow[t]{6}{*}{$\begin{array}{l}\text { GR-OV- } \\
\text { P-02 }\end{array}$} & Idaho fescue & $\begin{array}{c}\text { Festuca } \\
\text { idahoensis }\end{array}$ & 0 & 2.5 & 0 & 0 & 2.5 & 0 & 15 & 0 & 0 & 0 & 2 & 4.68 & 30 \\
\hline & Yarrow & $\begin{array}{c}\text { Achillea } \\
\text { millefolium }\end{array}$ & 0 & 0 & 0 & 0 & 0 & 0 & 2.5 & 0 & 0 & 0 & 0.25 & 0.79 & 10 \\
\hline & Bare ground & & 85 & 85 & 62.5 & 85 & 62.5 & 85 & 62.5 & 15 & 37.5 & 62.5 & 64.25 & 23.28 & \\
\hline & Rock & & 0 & 0 & 0 & 0 & 15 & 0 & 0 & 0 & 2.5 & 0 & 1.75 & 4.72 & \\
\hline & Litter & & 15 & 15 & 37.5 & 15 & 15 & 15 & 15 & 85 & 62.5 & 37.5 & 31.25 & 24.78 & \\
\hline & & Total Live & 0 & 2.5 & 0 & 0 & 2.5 & 0 & 17.5 & 0 & 0 & 0 & 2.25 & & \\
\hline \multirow[t]{8}{*}{$\begin{array}{l}\text { GR-OV- } \\
\text { P-03 }\end{array}$} & Red top & Agrostis alba & 15 & 15 & 2.5 & 0 & 0 & 15 & 0 & 2.5 & 2.5 & 15 & 6.75 & 7.17 & 70 \\
\hline & Idaho fescue & $\begin{array}{c}\text { Festuca } \\
\text { idahoensis }\end{array}$ & 2.5 & 15 & 15 & 15 & 15 & 2.5 & 15 & 15 & 15 & 2.5 & 11.25 & 6.04 & 100 \\
\hline & Yarrow & $\begin{array}{c}\text { Achillea } \\
\text { millefolium }\end{array}$ & 2.5 & 0 & 2.5 & 2.5 & 2.5 & 0 & 2.5 & 15 & 2.5 & 0 & 3 & 4.38 & 70 \\
\hline & $\begin{array}{c}\text { Unidentified } \\
\text { forb } \# 6\end{array}$ & & 0 & 0 & 0 & 0 & 2.5 & 0 & 0 & 0 & 0 & 0 & 0.25 & 0.79 & 10 \\
\hline & Bare ground & & 85 & 62.5 & 62.5 & 85 & 85 & 85 & 62.5 & 62.5 & 85 & 85 & 76 & 11.62 & \\
\hline & Rock & & 2.5 & 2.5 & 15 & 15 & 15 & 2.5 & 37.5 & 15 & 2.5 & 2.5 & 11 & 11.19 & \\
\hline & Litter & & 15 & 15 & 15 & 2.5 & 2.5 & 2.5 & 2.5 & 2.5 & 2.5 & 2.5 & 6.25 & 6.04 & \\
\hline & & Total Live & 20 & 30 & 20 & 17.5 & 20 & 17.5 & 17.5 & 32.5 & 20 & 17.5 & 21.25 & 43.43 & \\
\hline
\end{tabular}

* GR=Gregory, SB=Subirrigated, OV=Overflow, G=Good, M=Moderate, P=Poor 
Table 29. Production data from the Gregory Mine.

\begin{tabular}{|c|c|c|c|c|c|c|c|c|}
\hline & Life Form & Frame 1 & Frame 2 & Frame 3 & Frame 4 & & $\begin{array}{c}\text { Standard } \\
\text { Deviation }\end{array}$ & $\begin{array}{c}\text { Total } \\
\text { Production }\end{array}$ \\
\hline Transect ID* & & Wt (g) & Wt (g) & Wt (g) & Wt (g) & Mean & STD & $\mathrm{Kg} / \mathrm{ha}$ \\
\hline \multirow[t]{4}{*}{ GR-SB-G-01 } & Grass & 44.12 & 208.09 & 98.18 & 80.73 & 107.78 & 70.57 & 4311.20 \\
\hline & Forb & 14.99 & 16.11 & 15.57 & 8.68 & 6.92 & 3.47 & 276.75 \\
\hline & Shrub & 0 & 0 & 0 & 0 & 0.00 & 0.00 & 0.00 \\
\hline & Total & & & & & & & 4587.95 \\
\hline \multirow[t]{4}{*}{ GR-SB-G-02 } & Grass & 187.92 & 187.65 & 65.24 & 17.52 & 114.58 & 86.74 & 4583.30 \\
\hline & Forb & 13.62 & 10.57 & 36.56 & 30.08 & 22.71 & 12.60 & 908.30 \\
\hline & Shrub & 0 & 0 & 0 & 0 & 0.00 & 0.00 & 0.00 \\
\hline & Total & & & & & & & 5491.60 \\
\hline \multirow[t]{4}{*}{ GR-SB-G-03 } & Grass & 64.55 & 42.16 & 41.64 & 94.58 & 60.73 & 24.96 & 2429.30 \\
\hline & Forb & 0 & 0.81 & 9 & 0 & 2.45 & 4.38 & 98.10 \\
\hline & Shrub & 0 & 0 & 0 & 0 & 0.00 & 0.00 & 0.00 \\
\hline & Total & & & & & & & 2527.40 \\
\hline \multirow[t]{4}{*}{ GR-SB-M-01 } & Grass & 46.2 & 10.19 & 13.28 & 17.83 & 21.88 & 16.52 & 875.00 \\
\hline & Forb & 1.74 & 1.62 & 13.36 & 6 & 5.68 & 4.77 & 227.20 \\
\hline & Shrub & 0 & 0 & 0.53 & 0 & 0.13 & 0.27 & 5.30 \\
\hline & Total & & & & & & & 1107.50 \\
\hline
\end{tabular}


Table 29. Continued.

\begin{tabular}{|c|c|c|c|c|c|c|c|c|}
\hline & Life Form & Frame 1 & Frame 2 & Frame 3 & Frame 4 & & $\begin{array}{c}\text { Standard } \\
\text { Deviation }\end{array}$ & $\begin{array}{c}\text { Total } \\
\text { Production }\end{array}$ \\
\hline Transect ID* & & Wt (g) & Wt (g) & Wt (g) & Wt (g) & Mean & STD & Kg/ha \\
\hline GR-SB-M-02 & Grass & 14.8 & 57.5 & 14.75 & 20.75 & 26.95 & 20.56 & 1078.00 \\
\hline & Forb & 31.16 & 30.51 & 30.19 & 5.08 & 24.24 & 12.78 & 969.40 \\
\hline & Shrub & 0.19 & 0 & 0 & 0 & 0.05 & 0.10 & 1.90 \\
\hline & Total & & & & & & & 2049.30 \\
\hline & & & & & & & & \\
\hline GR-SB-M-03 & Grass & 52.37 & 25.56 & 29.22 & 22.65 & 32.45 & 13.55 & 1298.00 \\
\hline & Forb & 1.04 & 0 & 0 & 3 & 1.01 & 1.41 & 40.40 \\
\hline & Shrub & 0 & 0 & 0 & 0 & 0.00 & 0.00 & 0.00 \\
\hline & Total & & & & & & & 1338.40 \\
\hline & & & & & & & & \\
\hline GR-SB-P-01 & Grass & 9.53 & 1.5 & 0 & 4.85 & 3.97 & 4.22 & 158.80 \\
\hline & Forb & 0 & 0 & 0 & 0 & 0.00 & 0.00 & 0.00 \\
\hline & Shrub & 0 & 0 & 0 & 0 & 0.00 & 0.00 & 0.00 \\
\hline & Total & & & & & & & 158.80 \\
\hline & & & & & & & & \\
\hline GR-SB-P-02 & Grass & 42.41 & 4.16 & 25.49 & 17 & 22.27 & 16.04 & 890.60 \\
\hline & Forb & 0 & 0 & 0 & 0 & 0.00 & 0.00 & 0.00 \\
\hline & Shrub & 0 & 0 & 0 & 0 & 0.00 & 0.00 & 0.00 \\
\hline & Total & & & & & & & 890.60 \\
\hline
\end{tabular}


Table 29. Continued.

\begin{tabular}{|l|c|c|c|c|c|c|c|c|}
\hline & Life Form & Frame 1 & Frame 2 & Frame 3 & Frame 4 & & $\begin{array}{c}\text { Standard } \\
\text { Deviation }\end{array}$ & $\begin{array}{c}\text { Total } \\
\text { Production }\end{array}$ \\
\hline Transect ID* & & Wt (g) & Wt (g) & Wt (g) & Wt (g) & Mean & STD & Kg/ha \\
\hline GR-SB-P-03 & Grass & 0 & 0 & 0 & 36.92 & 9.23 & 18.46 & 369.20 \\
\hline & Forb & 0 & 0 & 0 & 0 & 0.00 & 0.00 & 0.00 \\
\hline & Shrub & 0 & 0 & 0 & 0 & 0.00 & 0.00 & 0.00 \\
\hline & & & & & & & & 369.20 \\
\hline
\end{tabular}


Table 29. Continued.

\begin{tabular}{|c|c|c|c|c|c|c|c|c|c|c|c|c|c|c|}
\hline & Life Form & $\mid \begin{array}{c}\text { Frame } \\
1\end{array}$ & $\begin{array}{c}\text { Frame } \\
2\end{array}$ & $\begin{array}{c}\text { Frame } \\
3\end{array}$ & $\begin{array}{c}\text { Frame } \\
4\end{array}$ & $\begin{array}{c}\text { Frame } \\
5\end{array}$ & $\begin{array}{c}\text { Frame } \\
6\end{array}$ & $\begin{array}{c}\text { Frame } \\
7\end{array}$ & $\begin{array}{c}\text { Frame } \\
8\end{array}$ & $\begin{array}{c}\text { Frame } \\
9\end{array}$ & $\begin{array}{c}\text { Frame } \\
10\end{array}$ & Mean & $\begin{array}{c}\text { Standard } \\
\text { Deviation }\end{array}$ & $\begin{array}{c}\text { Total } \\
\text { Production }\end{array}$ \\
\hline Transect ID* & & Wt (g) & Wt (g) & Wt (g) & $\mathrm{Wt}(\mathrm{g})$ & Wt (g) & Wt (g) & Wt (g) & Wt (g) & Wt (g) & $\mathrm{Wt}(\mathrm{g})$ & (g) & & $\mathrm{kg} / \mathrm{ha}$ \\
\hline & & & & & & & & & & & & & & \\
\hline \multirow[t]{5}{*}{ GR-OV-G-01 } & Grass & 3.77 & 9.07 & 3.77 & 6.51 & 6.5 & 6.39 & 10.84 & 16.4 & 17.03 & 10.71 & 9.10 & 4.71 & 1455.84 \\
\hline & Forb & 0.08 & 0 & 0 & 0 & 0 & 0 & 0 & 0 & 0 & 0 & 0.01 & 0.03 & 1.28 \\
\hline & Shrub & 0 & 0 & 0 & 0 & 0 & 0 & 0 & 0 & 0 & 0 & & & 0.00 \\
\hline & Total & 3.85 & 9.07 & 3.77 & 6.51 & 6.5 & 6.39 & 10.84 & 16.4 & 17.03 & 10.71 & 9.11 & 4.70 & 1457.12 \\
\hline & & & & & & & & & & & & & & 0.00 \\
\hline \multirow[t]{5}{*}{ GR-OV-G-02 } & Grass & 12.28 & 11.77 & 6.17 & 7.1 & 11.87 & 34.46 & 18.85 & 43.29 & 11.29 & 26.81 & 18.39 & 12.47 & 2942.24 \\
\hline & Forb & 1.76 & 3.47 & 1.18 & 0.45 & 1.88 & 0 & 0 & 0.04 & 0.7 & 1.63 & 1.11 & 1.11 & 177.76 \\
\hline & Shrub & 0 & 0 & 0 & 0 & 0 & 0 & 0 & 0 & 0 & 0 & & & 0.00 \\
\hline & Total & 14.04 & 15.24 & 7.35 & 7.55 & 13.75 & 34.46 & 18.85 & 43.33 & 11.99 & 28.44 & 19.50 & 12.02 & 3120.00 \\
\hline & & & & & & & & & & & & & & 0.00 \\
\hline \multirow[t]{5}{*}{ GR-OV-G-03 } & Grass & 15.04 & 10.25 & 5.46 & 10.24 & 5.81 & 8.07 & 16.76 & 6.85 & 3.95 & 4.5 & 8.69 & 4.38 & 1390.88 \\
\hline & Forb & 3.38 & 3.68 & 13.92 & 14.06 & 0.18 & 4.53 & 1.94 & 8.57 & 2.3 & 5.3 & 5.79 & 4.86 & 925.76 \\
\hline & Shrub & 0 & 0 & 0 & 0 & 0 & 0 & 0 & 0 & 0 & 0 & & & 0.00 \\
\hline & Total & 18.42 & 13.93 & 19.38 & 24.3 & 5.99 & 12.6 & \begin{tabular}{|l|}
18.7 \\
\end{tabular} & 15.42 & $\begin{array}{l}6.25 \\
\end{array}$ & \begin{tabular}{l|l}
9.8 \\
\end{tabular} & 14.48 & 5.96 & 2316.64 \\
\hline & & & & & & & & & & & & & & 0.00 \\
\hline \multirow[t]{4}{*}{ GR-OV-M-01 } & Grass & 7.52 & 2.25 & 3.15 & 2.4 & 4.46 & 7.01 & 2.1 & 4.37 & 5.25 & 5.34 & 4.39 & 1.93 & 701.60 \\
\hline & Forb & 1.3 & 0.53 & 0.47 & 0.7 & 0.2 & 0.55 & 1.85 & 3.25 & \begin{tabular}{l|l|}
1.22 \\
\end{tabular} & 0.75 & 1.08 & 0.90 & 173.12 \\
\hline & Shrub & 0 & 0 & 0 & 0 & 0 & 0 & 0 & 0 & 0 & 0 & & & 0.00 \\
\hline & Total & 8.82 & \begin{tabular}{|l|}
2.78 \\
\end{tabular} & 3.62 & 3.1 & 4.66 & 7.56 & 3.95 & 7.62 & $\begin{array}{l}6.47 \\
\end{array}$ & 6.09 & 5.47 & 2.13 & 874.72 \\
\hline
\end{tabular}


Table 29. Continued.

\begin{tabular}{|c|c|c|c|c|c|c|c|c|c|c|c|c|c|c|}
\hline & Life Form & $\begin{array}{c}\text { Frame } \\
1\end{array}$ & $\begin{array}{c}\text { Frame } \\
2\end{array}$ & Frame 3 & Frame 4| & Frame 5 & $\begin{array}{c}\text { Frame } \\
6\end{array}$ & Frame 7 & $\begin{array}{c}\text { Frame } \\
8\end{array}$ & Frame 9| & $\begin{array}{c}\text { Frame } \\
10\end{array}$ & Mean & $\begin{array}{c}\text { Standard } \\
\text { Deviation }\end{array}$ & \begin{tabular}{c|} 
Total \\
Production
\end{tabular} \\
\hline Transect ID* & & Wt (g) & Wt (g) & Wt (g) & Wt (g) & Wt (g) & Wt (g) & Wt (g) & Wt (g) & Wt (g) & $\mathrm{Wt}(\mathrm{g})$ & (g) & & $\mathrm{kg} / \mathrm{ha}$ \\
\hline \multirow[t]{4}{*}{ GR-OV-M-02 } & Grass & 3.1 & 3.65 & 5.23 & 2.81 & 5.08 & 3.5 & 6.87 & 28.11 & 4.58 & 4.24 & 6.72 & 7.61 & 1074.72 \\
\hline & Forb & 1.2 & 0.07 & 0.43 & 0.22 & 2 & 1.2 & 3 & 2 & 5.76 & 3.72 & 1.96 & 1.79 & 313.60 \\
\hline & Shrub & 0 & 0 & 0 & 0 & 0 & 0 & 0 & 0 & 0 & 0 & & & 0.00 \\
\hline & Total & 4.3 & 3.72 & 5.66 & 3.03 & 7.08 & 4.7 & 9.87 & 30.11 & 10.34 & 7.96 & 8.68 & 7.94 & 1388.32 \\
\hline \multirow[t]{5}{*}{ GR-OV-M-03 } & Grass & 3.73 & 13.27 & 0.71 & 14.16 & 13.48 & 1.08 & 2.71 & 4.46 & 7.83 & 2.14 & 6.36 & 5.40 & 1017.12 \\
\hline & Forb & 3 & 0.21 & 5.02 & 1.47 & 0.78 & 4.78 & 3.81 & 2.26 & 1.11 & 14.72 & 3.72 & 4.21 & 594.56 \\
\hline & Shrub & 0 & 0 & 0 & 0 & 0 & 0 & 0 & 0 & 0 & 0 & & & 0.00 \\
\hline & Total & 6.73 & 13.48 & 5.73 & 15.63 & 14.26 & 5.86 & 6.52 & 6.72 & 8.94 & 16.86 & 10.07 & 4.46 & 1611.68 \\
\hline & & & & & & & & & & & & & & 0.00 \\
\hline \multirow[t]{5}{*}{ GR-OV-P-01 } & Grass & 8.35 & 0 & 0 & 0 & 1 & 0 & 0 & 0 & 0 & 0 & 0.94 & 2.62 & 149.60 \\
\hline & Forb & 0 & 0 & 0 & 0 & 0 & 0 & 0 & 0 & 0 & 0 & 0.00 & 0.00 & 0.00 \\
\hline & Shrub & 0 & 0 & 0 & 0 & 0 & 0 & 0 & 0 & 0 & 0 & & & 0.00 \\
\hline & Total & 8.35 & 0 & 0 & 0 & 1 & 0 & 0 & 0 & 0 & 0 & 0.94 & 2.62 & 149.60 \\
\hline & & & & & & & & & & & & & & 0.00 \\
\hline \multirow[t]{5}{*}{ GR-OV-P-02 } & Grass & 0 & 0.35 & 0 & 0 & 0 & 0 & 0 & 0.3 & 0 & 0 & 0.07 & 0.14 & 10.40 \\
\hline & Forb & 0 & 0 & 0 & 0 & 0 & 0 & 0 & 0 & 0 & 0 & 0.00 & 0.00 & 0.00 \\
\hline & Shrub & 0 & 0 & 0 & 0 & 0 & 0 & 0 & 0 & 0 & 0 & & & 0.00 \\
\hline & Total & 0 & 0.35 & 0 & 0 & 0 & 0 & 0 & 0.3 & 0 & 0 & 0.07 & 0.14 & 10.40 \\
\hline & & & & & & & & & & & & & & 0.00 \\
\hline \multirow[t]{4}{*}{ GR-OV-P-03 } & Grass & 1 & 1.46 & 1.9 & 1 & 0.1 & 1.07 & 0.54 & 1 & 0.73 & 8.4 & 1.72 & 2.40 & 275.20 \\
\hline & Forb & 0 & 0 & 0.3 & 0.3 & 0 & 0 & 0.63 & 0.3 & 0.25 & 0 & 0.18 & 0.21 & 28.48 \\
\hline & Shrub & 0 & 0 & 0 & 0 & 0 & 0 & 0 & 0 & 0 & 0 & & & 0.00 \\
\hline & Total & 1 & 1.46 & 2.2 & 1.3 & 0.1 & 1.07 & 1.17 & 1.3 & 0.98 & 8.4 & 1.90 & 2.34 & 303.68 \\
\hline
\end{tabular}

* GR=Gregory, SB=Subirrigated, OV=Overflow, $\mathrm{G}=$ Good, $\mathrm{M}=$ Moderate, $\mathrm{P}=$ Poor 
Table 30. Field canopy cover data, total percent cover by species and sample area, standard deviation and species frequency from the Comet Mine.

\begin{tabular}{|c|c|c|c|c|c|c|c|c|c|c|c|c|c|c|c|}
\hline & & Frame \# & 1 & 2 & 3 & 4 & 5 & 6 & 7 & 8 & 9 & 10 & & & \\
\hline $\begin{array}{c}\text { Transect } \\
\text { ID* }^{*}\end{array}$ & $\begin{array}{l}\text { Common } \\
\text { Name }\end{array}$ & Species Name & $\begin{array}{l}\text { Mid } \\
\text { point }\end{array}$ & $\begin{array}{l}\text { Mid } \\
\text { point }\end{array}$ & $\begin{array}{l}\text { Mid } \\
\text { point }\end{array}$ & $\begin{array}{l}\text { Mid } \\
\text { point }\end{array}$ & $\begin{array}{c}\text { Mid } \\
\text { point }\end{array}$ & $\begin{array}{l}\text { Mid } \\
\text { point }\end{array}$ & $\begin{array}{c}\text { Mid } \\
\text { point }\end{array}$ & $\begin{array}{l}\text { Mid } \\
\text { point }\end{array}$ & $\begin{array}{l}\text { Mid } \\
\text { point }\end{array}$ & $\begin{array}{l}\text { Mid } \\
\text { point }\end{array}$ & $\begin{array}{c}\text { Mean } \\
\% \text { cover }\end{array}$ & SD & $\begin{array}{c}\text { Frequency } \\
(\%)\end{array}$ \\
\hline \multirow[t]{9}{*}{$\begin{array}{c}\text { CT-OV- } \\
\text { G-01 }\end{array}$} & Red top & Agrostis alba & 15 & 15 & 37.5 & 15 & 37.5 & 15 & 15 & 15 & 37.5 & 15 & 21.75 & 10.87 & 100 \\
\hline & $\begin{array}{c}\text { Slender } \\
\text { wheatgrass }\end{array}$ & $\begin{array}{c}\text { Agropyron } \\
\text { trachycaulum }\end{array}$ & 37.5 & 62.5 & 15 & 15 & 37.5 & 37.5 & 62.5 & 37.5 & 15 & 67.5 & 38.75 & 20.15 & 100 \\
\hline & $\begin{array}{c}\text { Western } \\
\text { wheatgrass }\end{array}$ & $\begin{array}{c}\text { Agropyron } \\
\text { smithii }\end{array}$ & 15 & 15 & 0 & 0 & 2.5 & 2.5 & 2.5 & 15 & 15 & 2.5 & 7 & 6.95 & 80 \\
\hline & Idaho fescue & $\begin{array}{c}\text { Festuca } \\
\text { idahoensis }\end{array}$ & 0 & 0 & 0 & 0 & 0 & 0 & 2.5 & 0 & 0 & 0 & 0.25 & 0.79 & 10 \\
\hline & Yarrow & $\begin{array}{c}\text { Achillea } \\
\text { millefolium }\end{array}$ & 2.5 & 0 & 0 & 0 & 0 & 0 & 0 & 0 & 0 & 0 & 0.25 & 0.79 & 10 \\
\hline & Bare ground & & 15 & 2.5 & 15 & 15 & 15 & 2.5 & 15 & 2.5 & 2.5 & 2.5 & 8.75 & 6.59 & \\
\hline & Rock & & 2.5 & 2.5 & 2.5 & 2.5 & 2.5 & 2.5 & 2.5 & 2.5 & 2.5 & 2.5 & 60 & 0.00 & \\
\hline & Litter & & 37.5 & 62.5 & 62.5 & 62.5 & 62.5 & 62.5 & 62.5 & 62.5 & 62.5 & 62.5 & & & \\
\hline & & Total Live & 70 & 92.5 & 52.5 & 30 & 77.5 & 55 & 82.5 & 67.5 & 67.5 & 85 & 68 & & \\
\hline \multirow[t]{4}{*}{$\begin{array}{l}\text { CT-OV- } \\
\text { G-02 }\end{array}$} & Red top & Agrostis alba & 37.5 & 62.5 & 37.5 & 37.5 & 37.5 & 37.5 & 15 & 62.5 & 85 & 32.5 & 44.5 & 19.85 & 100 \\
\hline & $\begin{array}{c}\text { Slender } \\
\text { wheatgrass }\end{array}$ & $\begin{array}{c}\text { Agropyron } \\
\text { trachycaulum }\end{array}$ & 15 & 37.5 & 37.5 & 37.5 & 2.5 & 15 & 37.5 & 2.5 & 0 & 2.5 & 18.75 & 16.93 & 100 \\
\hline & $\begin{array}{c}\text { Western } \\
\text { wheatgrass }\end{array}$ & $\begin{array}{c}\text { Agropyron } \\
\text { smithii }\end{array}$ & 15 & 2.5 & 2.5 & 0 & 0 & 0 & 0 & 2.5 & 0 & 2.5 & 2.5 & 4.56 & 50 \\
\hline & Idaho fescue & $\begin{array}{c}\text { Festuca } \\
\text { idahoensis }\end{array}$ & 0 & 0 & 0 & 2.5 & 0 & 0 & 2.5 & 0 & 0 & 0 & 0.5 & 1.05 & 20 \\
\hline
\end{tabular}


Table 30. Continued.

\begin{tabular}{|c|c|c|c|c|c|c|c|c|c|c|c|c|c|c|c|}
\hline & & Frame \# & 1 & 2 & 3 & 4 & 5 & 6 & 7 & 8 & 9 & 10 & & & \\
\hline \multirow[t]{8}{*}{$\begin{array}{c}\text { Transect } \\
I D^{\star}\end{array}$} & $\begin{array}{l}\text { Common } \\
\text { Name }\end{array}$ & Species Name & $\begin{array}{c}\text { Mid } \\
\text { point }\end{array}$ & $\begin{array}{c}\text { Mid } \\
\text { point }\end{array}$ & $\begin{array}{c}\text { Mid } \\
\text { point }\end{array}$ & $\begin{array}{c}\text { Mid } \\
\text { point }\end{array}$ & $\begin{array}{c}\text { Mid } \\
\text { point }\end{array}$ & $\begin{array}{c}\text { Mid } \\
\text { point }\end{array}$ & $\begin{array}{c}\text { Mid } \\
\text { point }\end{array}$ & $\begin{array}{c}\text { Mid } \\
\text { point }\end{array}$ & $\begin{array}{c}\text { Mid } \\
\text { point }\end{array}$ & $\begin{array}{l}\text { Mid } \\
\text { point }\end{array}$ & $\begin{array}{c}\text { Mean } \\
\% \text { cover }\end{array}$ & SD & $\begin{array}{c}\text { Frequency } \\
(\%)\end{array}$ \\
\hline & Yarrow & $\begin{array}{c}\text { Achillea } \\
\text { millefolium }\end{array}$ & 0 & 0 & 0 & 0 & 0 & 0 & 0 & 0 & 0 & 2.5 & 0.25 & 0.79 & 10 \\
\hline & $\begin{array}{l}\text { Dwarf } \\
\text { Fireweed }\end{array}$ & $\begin{array}{l}\text { Epilobium } \\
\text { latifolium }\end{array}$ & 0 & 0 & 0 & 0 & 0 & 0 & 0 & 0 & 0 & 2.5 & 0.25 & 0.79 & 10 \\
\hline & White clover & $\begin{array}{l}\text { Trifolium } \\
\text { repens }\end{array}$ & 0 & 0 & 0 & 0 & 0 & 0 & 0 & 0 & 15 & 0 & 1.5 & 4.74 & 10 \\
\hline & Bare ground & & 15 & 2.5 & 15 & 15 & 15 & 15 & 37.5 & 15 & 2.5 & 2.5 & 13.5 & 10.29 & \\
\hline & Rock & & 2.5 & 2.5 & 2.5 & 2.5 & 2.5 & \begin{tabular}{|l|}
37.5 \\
\end{tabular} & 15 & 2.5 & 2.5 & 2.5 & 7.25 & 11.33 & \\
\hline & Litter & & 37.5 & 15 & 15 & 37.5 & 62.5 & 15 & 15 & 62.5 & 15 & 37.5 & 31.25 & 19.41 & \\
\hline & & Total Live & 67.5 & 103 & 77.5 & 77.5 & 40 & 52.5 & 55 & 67.5 & 100 & 42.5 & 68.25 & & \\
\hline \multirow[t]{8}{*}{$\begin{array}{c}\text { CT-OV- } \\
\text { G-03 }\end{array}$} & Red top & Agrostis alba & 15 & 2.5 & 2.5 & 2.5 & 2.5 & 2.5 & 2.5 & 2.5 & 0 & 37.5 & 7 & 11.47 & 90 \\
\hline & $\begin{array}{c}\text { Slender } \\
\text { wheatgrass }\end{array}$ & $\begin{array}{c}\text { Agropyron } \\
\text { trachycaulum }\end{array}$ & 62.5 & 62.5 & 37.5 & 37.5 & 37.5 & 85 & 85 & 37.5 & 37.5 & 15 & 49.75 & 23.02 & 100 \\
\hline & $\begin{array}{c}\text { Western } \\
\text { wheatgrass }\end{array}$ & $\begin{array}{c}\text { Agropyron } \\
\text { smithii }\end{array}$ & 2.5 & 37.5 & 37.5 & 62.5 & 15 & 15 & 15 & 15 & 62.5 & 0 & 26.25 & 22.71 & 90 \\
\hline & Yarrow & $\begin{array}{c}\text { Achillea } \\
\text { millefolium }\end{array}$ & 2.5 & 2.5 & 2.5 & 2.5 & 15 & 2.5 & 0 & 0 & 0 & 0 & 2.75 & 4.48 & 60 \\
\hline & Bare ground & & 2.5 & 2.5 & 15 & 2.5 & 2.5 & 2.5 & 2.5 & 37.5 & 2.5 & 37.5 & 10.75 & 14.63 & \\
\hline & Rock & & 2.5 & 2.5 & 2.5 & 2.5 & 2.5 & 2.5 & 2.5 & 2.5 & 2.5 & 2.5 & 2.5 & 0.00 & \\
\hline & Litter & & 37.5 & 37.5 & 15 & 15 & 62.5 & 15 & 15 & 37.5 & 15 & 62.5 & 31.25 & 19.41 & \\
\hline & & Total Live & 82.5 & 105 & 80 & 105 & 70 & 105 & 103 & 55 & 100 & 52.5 & 85.75 & & \\
\hline
\end{tabular}


Table 30. Continued.

\begin{tabular}{|c|c|c|c|c|c|c|c|c|c|c|c|c|c|c|c|}
\hline & & Frame \# & 1 & 2 & 3 & 4 & 5 & 6 & 7 & 8 & 9 & 10 & & & \\
\hline $\begin{array}{c}\text { Transect } \\
I^{*}\end{array}$ & $\begin{array}{l}\text { Common } \\
\text { Name }\end{array}$ & Species Name & $\begin{array}{l}\text { Mid } \\
\text { point }\end{array}$ & $\begin{array}{l}\text { Mid } \\
\text { point }\end{array}$ & $\begin{array}{c}\text { Mid } \\
\text { point }\end{array}$ & $\begin{array}{c}\text { Mid } \\
\text { point }\end{array}$ & $\begin{array}{c}\text { Mid } \\
\text { point }\end{array}$ & \begin{tabular}{|c|} 
Mid \\
point
\end{tabular} & $\begin{array}{l}\text { Mid } \\
\text { point }\end{array}$ & $\begin{array}{l}\text { Mid } \\
\text { point }\end{array}$ & $\begin{array}{l}\text { Mid } \\
\text { point }\end{array}$ & $\begin{array}{l}\text { Mid } \\
\text { point }\end{array}$ & $\begin{array}{c}\text { Mean } \\
\% \text { cover }\end{array}$ & SD & $\begin{array}{c}\text { Frequency } \\
(\%)\end{array}$ \\
\hline \multirow[t]{10}{*}{$\begin{array}{l}\text { CT-OV- } \\
\text { M-01 }\end{array}$} & Red top & Agrostis alba & 15 & 15 & 2.5 & 2.5 & 37.5 & 15 & 15 & 37.5 & 15 & 2.5 & 15.75 & 12.80 & 100 \\
\hline & $\begin{array}{c}\text { Slender } \\
\text { wheatgrass }\end{array}$ & $\begin{array}{c}\text { Agropyron } \\
\text { trachycaulum }\end{array}$ & 2.5 & 2.5 & 15 & 37.5 & 2.5 & 0 & 0 & 2.5 & 15 & 37.5 & 11.5 & $\mid 14.78$ & 80 \\
\hline & Idaho fescue & $\begin{array}{c}\text { Festuca } \\
\text { idahoensis }\end{array}$ & 0 & 0 & 0 & 0 & 2.5 & 0 & 0 & 0 & 2.5 & 2.5 & 0.75 & 1.21 & 30 \\
\hline & $\begin{array}{c}\text { Unidentified } \\
\text { grass \#1 }\end{array}$ & & 0 & 0 & 0 & 0 & 0 & 0 & 15 & 0 & 0 & 0 & 1.5 & 4.74 & 10 \\
\hline & Yarrow & $\begin{array}{c}\text { Achillea } \\
\text { millefolium }\end{array}$ & 2.5 & 15 & 37.5 & 15 & 0 & 0 & 2.5 & 0 & 0 & 0 & 7.25 & 12.22 & 50 \\
\hline & $\begin{array}{l}\text { Dwarf } \\
\text { fireweed }\end{array}$ & $\begin{array}{l}\text { Epilobium } \\
\text { latifolium }\end{array}$ & 0 & 2.5 & 0 & 0 & 0 & 0 & 0 & 0 & 0 & 0 & 0.25 & 0.79 & 10 \\
\hline & Bare ground & & 85 & 37.5 & 37.5 & 62.5 & 37.5 & 62.5 & 62.5 & 62.5 & 62.5 & 15 & 52.5 & 20.10 & \\
\hline & Rock & & 2.5 & 2.5 & 2.5 & 2.5 & 2.5 & 15 & 2.5 & 2.5 & 15 & 2.5 & 5 & 5.27 & \\
\hline & Litter & & 15 & 62.5 & 62.5 & 15 & 37.5 & 15 & 37.5 & 37.5 & 15 & 85 & 38.25 & 24.78 & \\
\hline & & Total Live & 20 & 35 & 55 & 55 & 42.5 & 15 & 32.5 & 40 & 32.5 & 42.5 & 37 & & \\
\hline \multirow[t]{3}{*}{$\begin{array}{c}\text { CT-OV- } \\
\text { M-02 }\end{array}$} & Red top & Agrostis alba & 15 & 15 & 15 & 15 & 15 & 37.5 & 37.5 & 15 & 37.5 & 15 & 21.75 & 10.87 & 100 \\
\hline & \begin{tabular}{|c|} 
Slender \\
wheatgrass
\end{tabular} & $\begin{array}{c}\text { Agropyron } \\
\text { trachycaulum }\end{array}$ & 2.5 & 0 & 2.5 & 2.5 & 0 & 2.5 & 0 & 2.5 & 2.5 & 0 & 1.5 & 1.29 & 60 \\
\hline & $\begin{array}{c}\text { Western } \\
\text { wheatgrass }\end{array}$ & $\begin{array}{c}\text { Agropyron } \\
\text { smithii }\end{array}$ & 0 & 0 & 0 & 2.5 & 0 & 0 & 0 & 0 & 0 & 0 & 0.25 & 0.79 & 10 \\
\hline
\end{tabular}


Table 30. Continued.

\begin{tabular}{|c|c|c|c|c|c|c|c|c|c|c|c|c|c|c|c|}
\hline & & Frame \# & 1 & 2 & 3 & 4 & 5 & 6 & 7 & 8 & 9 & 10 & & & \\
\hline \multirow[t]{8}{*}{$\begin{array}{c}\text { Transect } \\
I^{*}\end{array}$} & $\begin{array}{l}\text { Common } \\
\text { Name }\end{array}$ & Species Name & $\begin{array}{l}\text { Mid } \\
\text { point }\end{array}$ & $\begin{array}{l}\text { Mid } \\
\text { point }\end{array}$ & $\begin{array}{c}\text { Mid } \\
\text { point }\end{array}$ & $\begin{array}{c}\text { Mid } \\
\text { point }\end{array}$ & $\begin{array}{c}\text { Mid } \\
\text { point }\end{array}$ & \begin{tabular}{|c|} 
Mid \\
point
\end{tabular} & $\begin{array}{l}\text { Mid } \\
\text { point }\end{array}$ & $\begin{array}{l}\text { Mid } \\
\text { point }\end{array}$ & $\begin{array}{l}\text { Mid } \\
\text { point }\end{array}$ & $\begin{array}{l}\text { Mid } \\
\text { point }\end{array}$ & $\begin{array}{c}\text { Mean } \\
\% \text { cover }\end{array}$ & $S D$ & $\begin{array}{c}\text { Frequency } \\
(\%)\end{array}$ \\
\hline & Idaho fescue & $\begin{array}{c}\text { Festuca } \\
\text { idahoensis }\end{array}$ & 0 & 0 & 2.5 & 0 & 0 & 0 & 0 & 0 & 0 & 0 & 0.25 & 0.79 & 10 \\
\hline & Yarrow & $\begin{array}{c}\text { Achillea } \\
\text { millefolium }\end{array}$ & 15 & 2.5 & 2.5 & 2.5 & 0 & 0 & 0 & 0 & 0 & 0 & 2.25 & 4.63 & 40 \\
\hline & White clover & $\begin{array}{l}\text { Trifolium } \\
\text { repens }\end{array}$ & 0 & 37.5 & 0 & 0 & 0 & 0 & 0 & 0 & 0 & 0 & 3.75 & 11.86 & 10 \\
\hline & Bare ground & & 32.5 & 15 & 62.5 & 37.5 & 62.5 & 62.5 & 62.5 & 62.5 & 37.5 & 85 & 52 & 20.58 & \\
\hline & Rock & & 15 & 2.5 & 2.5 & 37.5 & 15 & 2.5 & 2.5 & 2.5 & 2.5 & 2.5 & 8.5 & 11.44 & \\
\hline & Litter & & 2.5 & 37.5 & 15 & 15 & 37.5 & 15 & 15 & 15 & 37.5 & 15 & 20.5 & 12.35 & \\
\hline & & Total Live & 32.5 & 55 & 22.5 & 22.5 & 15 & 40 & 37.5 & 17.5 & 40 & 15 & 29.75 & & \\
\hline \multirow[t]{9}{*}{$\begin{array}{c}\text { CT-OV- } \\
\text { M-03 }\end{array}$} & Red top & Agrostis alba & 15 & 15 & 15 & 15 & 37.5 & 15 & 2.5 & 15 & 2.5 & 15 & 14.75 & 9.53 & 100 \\
\hline & \begin{tabular}{|c|}
$\begin{array}{c}\text { Slender } \\
\text { wheatgrass }\end{array}$ \\
\end{tabular} & $\begin{array}{c}\text { Agropyron } \\
\text { trachycaulum }\end{array}$ & 15 & 2.5 & 15 & 2.5 & 15 & 37.5 & 15 & 15 & 37.5 & 37.5 & 19.25 & 13.54 & 100 \\
\hline & Idaho fescue & $\begin{array}{c}\text { Festuca } \\
\text { idahoensis }\end{array}$ & 0 & 0 & 0 & 0 & 0 & 0 & 0 & 0 & 2.5 & 0 & 0.25 & 0.79 & 10 \\
\hline & $\begin{array}{c}\text { Dwarf } \\
\text { fireweed }\end{array}$ & $\begin{array}{l}\text { Epilobium } \\
\text { latifolium }\end{array}$ & 0 & 0 & 0 & 0 & 0 & 15 & 2.5 & 0 & 0 & 0 & 1.75 & 4.72 & 20 \\
\hline & Yarrow & $\begin{array}{c}\text { Achillea } \\
\text { millefolium }\end{array}$ & 0 & 0 & 0 & 0 & 0 & 0 & 0 & 2.5 & 0 & 0 & 0.25 & 0.79 & 10 \\
\hline & Bare ground & & 62.5 & 62.5 & 62.5 & 62.5 & 37.5 & 15 & 85 & 62.5 & 62.5 & 37.5 & 55 & 19.58 & \\
\hline & Rock & & 2.5 & 2.5 & 2.5 & 15 & 2.5 & 15 & 2.5 & 2.5 & 2.5 & 2.5 & 5 & 5.27 & \\
\hline & Litter & & 15 & 37.5 & 15 & 15 & 37.5 & 37.5 & 15 & 15 & 15 & 37.5 & 24 & 11.62 & \\
\hline & & Total Live & 30 & 17.5 & 30 & 17.5 & 52.5 & 67.5 & 20 & 32.5 & 42.5 & 52.5 & 36.25 & & \\
\hline
\end{tabular}


Table 30. Continued.

\begin{tabular}{|c|c|c|c|c|c|c|c|c|c|c|c|c|c|c|c|}
\hline & & Frame \# & 1 & 2 & 3 & 4 & 5 & 6 & 7 & 8 & 9 & 10 & & & \\
\hline $\begin{array}{c}\text { Transect } \\
I D^{*}\end{array}$ & $\begin{array}{l}\text { Common } \\
\text { Name }\end{array}$ & Species Name & $\begin{array}{c}\text { Mid } \\
\text { point }\end{array}$ & $\begin{array}{l}\text { Mid } \\
\text { point }\end{array}$ & $\begin{array}{l}\text { Mid } \\
\text { point }\end{array}$ & $\begin{array}{c}\text { Mid } \\
\text { point }\end{array}$ & $\begin{array}{l}\text { Mid } \\
\text { point }\end{array}$ & $\begin{array}{c}\text { Mid } \\
\text { point }\end{array}$ & $\begin{array}{l}\text { Mid } \\
\text { point }\end{array}$ & $\begin{array}{l}\text { Mid } \\
\text { point }\end{array}$ & $\begin{array}{l}\text { Mid } \\
\text { point }\end{array}$ & $\begin{array}{l}\text { Mid } \\
\text { point }\end{array}$ & $\begin{array}{c}\text { Mean } \\
\% \text { cover }\end{array}$ & SD & $\begin{array}{c}\text { Frequency } \\
(\%)\end{array}$ \\
\hline \multirow[t]{4}{*}{$\begin{array}{l}\text { CT-OV- } \\
\text { P-01 }\end{array}$} & Bare ground & & 67.5 & 67.5 & 85 & 85 & 67.5 & 85 & 85 & 85 & 85 & 67.5 & 78 & 9.04 & \\
\hline & Rock & & 37.5 & 37.5 & 15 & 15 & 37.5 & 15 & 15 & 15 & 2.5 & 37.5 & 22.75 & 13.25 & \\
\hline & Litter & & 2.5 & 15 & 2.5 & 15 & 2.5 & 2.5 & 15 & 15 & 15 & 15 & 10 & 6.45 & \\
\hline & & Total Live & 0 & 0 & 0 & 0 & 0 & 0 & 0 & 0 & 0 & 0 & 0 & & \\
\hline & & & & & & & & & & & & & & & \\
\hline \multirow[t]{4}{*}{$\begin{array}{c}\text { CT-OV- } \\
\text { P-02 }\end{array}$} & Bare ground & & 97.5 & 85 & 97.5 & 85 & 97.5 & 62.5 & 85 & 85 & 97.5 & 62.5 & 85.5 & 13.48 & \\
\hline & Rock & & 2.5 & 2.5 & 2.5 & 2.5 & 2.5 & 2.5 & 2.5 & 2.5 & 2.5 & 2.5 & 2.5 & 0.00 & \\
\hline & Litter & & 2.5 & 15 & 2.5 & 15 & 2.5 & 37.5 & 15 & 15 & 2.5 & 37.5 & 14.5 & 13.48 & \\
\hline & & Total Live & 0 & 0 & 0 & 0 & 0 & 0 & 0 & 0 & 0 & 0 & 0 & & \\
\hline & & & & & & & & & & & & & & & \\
\hline \multirow[t]{7}{*}{$\begin{array}{l}\text { CT-OV- } \\
\text { P-03 }\end{array}$} & Red top & Agrostis alba & 0 & 0 & 0 & 2.5 & 2.5 & 2.5 & 2.5 & 2.5 & 0 & 0 & 1.25 & 1.32 & 50 \\
\hline & \begin{tabular}{|c|} 
Slender \\
wheatgrass
\end{tabular} & $\begin{array}{c}\text { Agropyron } \\
\text { trachycaulum }\end{array}$ & 0 & 0 & 0 & 0 & 0 & 0 & 15 & 0 & 0 & 0 & 1.5 & 4.74 & 10 \\
\hline & Yarrow & $\begin{array}{c}\text { Achillea } \\
\text { millefolium }\end{array}$ & 0 & 0 & 0 & 0 & 2.5 & 0 & 0 & 0 & 0 & 0 & 0.25 & 0.79 & 10 \\
\hline & Bare ground & & 37.5 & 92.5 & 85 & 85 & 85 & 85 & 85 & 62.5 & 85 & 85 & 78.75 & 16.43 & \\
\hline & Rock & & 62.5 & 2.5 & 2.5 & 2.5 & 2.5 & 15 & 2.5 & 2.5 & 2.5 & 2.5 & 9.75 & 18.95 & \\
\hline & Litter & & 2.5 & 2.5 & 15 & 15 & 15 & 2.5 & 15 & 62.5 & 15 & 15 & 16 & 17.37 & \\
\hline & & Total Live & 0 & 0 & 0 & 2.5 & 5 & 2.5 & 17.5 & 2.5 & 0 & 0 & 3 & & \\
\hline
\end{tabular}


Table 30. Continued.

\begin{tabular}{|c|c|c|c|c|c|c|c|c|c|c|c|c|c|c|c|}
\hline & & Frame \# & 1 & 2 & 3 & 4 & 5 & 6 & 7 & 8 & 9 & 10 & & & \\
\hline 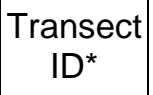 & $\begin{array}{l}\text { Common } \\
\text { Name }\end{array}$ & Species Name & $\begin{array}{l}\text { Mid } \\
\text { point }\end{array}$ & $\begin{array}{c}\text { Mid } \\
\text { point }\end{array}$ & $\begin{array}{c}\text { Mid } \\
\text { point }\end{array}$ & $\begin{array}{c}\text { Mid } \\
\text { point }\end{array}$ & $\begin{array}{c}\text { Mid } \\
\text { point }\end{array}$ & $\begin{array}{l}\text { Mid } \\
\text { point }\end{array}$ & $\begin{array}{c}\text { Mid } \\
\text { point }\end{array}$ & $\begin{array}{c}\text { Mid } \\
\text { point }\end{array}$ & $\begin{array}{l}\text { Mid } \\
\text { point }\end{array}$ & $\begin{array}{c}\text { Mid } \\
\text { point }\end{array}$ & $\begin{array}{c}\text { Mean } \\
\% \text { cover }\end{array}$ & SD & $\begin{array}{c}\text { Frequency } \\
(\%)\end{array}$ \\
\hline \multirow[t]{6}{*}{$\begin{array}{c}\text { CT-SB- } \\
\text { G-01 }\end{array}$} & Red top & Agrostis alba & 85 & 62.5 & 62.5 & 85 & 85 & 37.5 & 62.5 & 37.5 & 62.5 & 85 & 66.5 & 18.60 & 100 \\
\hline & Horsetail & Equisetum arvense & 0 & 0 & 0 & 0 & 2.5 & 0 & 0 & 0 & 0 & 0 & 0.25 & 0.79 & 10 \\
\hline & $\begin{array}{l}\text { Bare } \\
\text { ground }\end{array}$ & & 2.5 & 15 & 2.5 & 2.5 & 2.5 & 37.5 & 15 & 15 & 15 & 2.5 & 11 & 11.19 & \\
\hline & Rock & & 2.5 & 2.5 & 2.5 & 2.5 & 2.5 & 2.5 & 2.5 & 2.5 & 2.5 & 2.5 & 2.5 & 0.00 & \\
\hline & Litter & & 15 & 37.5 & 37.5 & 37.5 & 15 & 37.5 & 37.5 & 62.5 & 37.5 & 37.5 & 35.5 & 13.32 & \\
\hline & & Total Live & 85 & 62.5 & 62.5 & 85 & 87.5 & 37.5 & 62.5 & 37.5 & 62.5 & 85 & 66.75 & & \\
\hline \multirow[t]{9}{*}{$\begin{array}{c}\text { CT-SB- } \\
\text { G-02 }\end{array}$} & Red top & Agrostis alba & 62.5 & 62.5 & 62.5 & 37.5 & 15 & 37.5 & 85 & 37.5 & 62.5 & 85 & 54.75 & 22.47 & 100 \\
\hline & Horsetail & Equisetum arvense & 15 & 15 & 15 & 0 & 0 & 0 & 0 & 0 & 2.5 & 15 & 6.25 & 7.57 & 50 \\
\hline & Yarrow & Achillea millefolium & 2.5 & 2.5 & 15 & 0 & 0 & 0 & 0 & 0 & 0 & 0 & 2 & 4.68 & 30 \\
\hline & $\begin{array}{c}\text { Dwarf } \\
\text { fireweed }\end{array}$ & $\begin{array}{l}\text { Epilobium } \\
\text { latifolium }\end{array}$ & 2.5 & 2.5 & 2.5 & 0 & 0 & 2.5 & 2.5 & 37.5 & 2.5 & 15 & 6.75 & 11.61 & 80 \\
\hline & $\begin{array}{c}\text { Bare } \\
\text { ground }\end{array}$ & & 15 & 15 & 15 & 37.5 & 85 & 15 & 2.5 & 15 & 15 & 2.5 & 21.75 & 24.18 & \\
\hline & Rock & & 2.5 & 2.5 & 2.5 & 2.5 & 2.5 & 2.5 & 2.5 & 2.5 & 2.5 & 2.5 & 2.5 & 0.00 & \\
\hline & Litter & & 15 & 15 & 15 & 37.5 & 15 & 62.5 & 37.5 & 37.5 & 37.5 & 15 & 28.75 & 16.30 & \\
\hline & & Total Live & 2.5 & 82.5 & 95 & 37.5 & 15 & 40 & 87.5 & 75 & 67.5 & 115 & 69.75 & & \\
\hline & & & & & & & & & & & & & & & \\
\hline
\end{tabular}


Table 30. Continued.

\begin{tabular}{|c|c|c|c|c|c|c|c|c|c|c|c|c|c|c|c|}
\hline & & Frame \# & 1 & 2 & 3 & 4 & 5 & 6 & 7 & 8 & 9 & 10 & & & \\
\hline $\begin{array}{c}\text { Transect } \\
\text { ID* }\end{array}$ & $\begin{array}{l}\text { Common } \\
\text { Name }\end{array}$ & Species Name & $\begin{array}{l}\text { Mid } \\
\text { point }\end{array}$ & $\begin{array}{c}\text { Mid } \\
\text { point }\end{array}$ & $\begin{array}{c}\text { Mid } \\
\text { point }\end{array}$ & $\begin{array}{c}\text { Mid } \\
\text { point }\end{array}$ & $\begin{array}{c}\text { Mid } \\
\text { point }\end{array}$ & $\begin{array}{c}\text { Mid } \\
\text { point }\end{array}$ & $\begin{array}{c}\text { Mid } \\
\text { point }\end{array}$ & $\begin{array}{c}\text { Mid } \\
\text { point }\end{array}$ & $\begin{array}{c}\text { Mid } \\
\text { point }\end{array}$ & $\begin{array}{c}\text { Mid } \\
\text { point }\end{array}$ & $\begin{array}{c}\text { Mean } \\
\% \text { cover }\end{array}$ & SD & $\begin{array}{c}\text { Frequency } \\
(\%)\end{array}$ \\
\hline \multirow[t]{7}{*}{$\begin{array}{c}\text { CT-SB- } \\
\text { G-03 }\end{array}$} & Red top & Agrostis alba & 85 & 85 & 85 & 62.5 & 97.5 & 85 & 85 & 62.5 & 85 & 85 & 81.75 & 10.87 & 100 \\
\hline & Horsetail & Equisetum arvense & 0 & 0 & 2.5 & 2.5 & 0 & 2.5 & 0 & 0 & 0 & 0 & 0.75 & 1.21 & 30 \\
\hline & Yarrow & Achillea millefolium & 2.5 & 0 & 0 & 2.5 & 2.5 & 15 & 0 & 0 & 15 & 15 & 5.25 & 6.82 & 60 \\
\hline & $\begin{array}{l}\text { Bare } \\
\text { ground }\end{array}$ & & 2.5 & 2.5 & 2.5 & 15 & 2.5 & 2.5 & 2.5 & 15 & 2.5 & 2.5 & 5 & 5.27 & \\
\hline & Rock & & 2.5 & 2.5 & 2.5 & 2.5 & 2.5 & 2.5 & 2.5 & 2.5 & 2.5 & 2.5 & 2.5 & 0.00 & \\
\hline & Litter & & 15 & 37.5 & 37.5 & 37.5 & 15 & 15 & 15 & 37.5 & 15 & 15 & 24 & 11.62 & \\
\hline & & Total Live & 87.5 & 85 & 87.5 & 67.5 & 100 & 103 & 85 & 62.5 & 100 & 100 & 87.75 & & \\
\hline \multirow[t]{10}{*}{$\begin{array}{c}\text { CT-SB- } \\
\text { M-01 } \\
\end{array}$} & Red Top & Agrostis alba & 15 & 2.5 & 37.5 & 62.5 & 15 & 62.5 & 2.5 & 15 & 2.5 & 2.5 & 21.75 & 24.01 & 100 \\
\hline & \begin{tabular}{|c|} 
Slender \\
wheatgrass
\end{tabular} & $\begin{array}{c}\text { Agropyron } \\
\text { trachycaulum }\end{array}$ & 0 & 15 & 0 & 0 & 0 & 0 & 32.5 & 2.5 & 15 & 15 & 8 & 11.04 & 50 \\
\hline & $\begin{array}{c}\text { Tufted } \\
\text { hairgrass }\end{array}$ & $\begin{array}{c}\text { Deschampsia } \\
\text { caespitosa }\end{array}$ & 0 & 2.5 & 15 & 0 & 0 & 0 & 2.5 & 0 & 0 & 0 & 2 & 4.68 & 30 \\
\hline & $\begin{array}{c}\text { Dwarf } \\
\text { fireweed }\end{array}$ & $\begin{array}{l}\text { Epilobium } \\
\text { latifolium }\end{array}$ & 2.5 & 2.5 & 2.5 & 0 & 0 & 2.5 & 0 & 0 & 15 & 2.5 & 2.75 & 4.48 & 60 \\
\hline & Yarrow & Achillea millefolium & 0 & 2.5 & 2.5 & 0 & 0 & 2.5 & 0 & 0 & 2.5 & 2.5 & 1.25 & 1.32 & 50 \\
\hline & White clover & Trifolium repens & 0 & 0 & 0 & 0 & 0 & 0 & 0 & 0 & 0 & 15 & 1.5 & 4.74 & 10 \\
\hline & $\begin{array}{l}\text { Bare } \\
\text { ground }\end{array}$ & & 85 & 85 & 2.5 & 37.5 & 85 & 62.5 & 37.5 & 85 & 62.5 & 37.5 & 58 & 28.48 & \\
\hline & Rock & & 2.5 & 2.5 & 2.5 & 2.5 & 2.5 & 2.5 & 2.5 & 2.5 & 2.5 & 2.5 & 2.5 & 0.00 & \\
\hline & Litter & & 2.5 & 2.5 & 2.5 & 2.5 & 15 & 2.5 & 37.5 & 15 & 15 & 37.5 & 13.25 & 14.00 & \\
\hline & & Total Live & 17.5 & 25 & 57.5 & 62.5 & 15 & 67.5 & 37.5 & 17.5 & 35 & 37.5 & 37.25 & & \\
\hline
\end{tabular}


Table 30. Continued.

\begin{tabular}{|c|c|c|c|c|c|c|c|c|c|c|c|c|c|c|c|}
\hline & & Frame \# & 1 & 2 & 3 & 4 & 5 & 6 & 7 & 8 & 9 & 10 & & & \\
\hline $\begin{array}{c}\text { Transect } \\
I^{*}\end{array}$ & $\begin{array}{l}\text { Common } \\
\text { Name }\end{array}$ & Species Name & $\begin{array}{l}\text { Mid } \\
\text { point }\end{array}$ & $\begin{array}{l}\text { Mid } \\
\text { point }\end{array}$ & $\begin{array}{c}\text { Mid } \\
\text { point }\end{array}$ & $\begin{array}{l}\text { Mid } \\
\text { point }\end{array}$ & $\begin{array}{c}\text { Mid } \\
\text { point }\end{array}$ & \begin{tabular}{|c|} 
Mid \\
point
\end{tabular} & $\begin{array}{l}\text { Mid } \\
\text { point }\end{array}$ & $\begin{array}{l}\text { Mid } \\
\text { point }\end{array}$ & $\begin{array}{l}\text { Mid } \\
\text { point }\end{array}$ & $\begin{array}{l}\text { Mid } \\
\text { point }\end{array}$ & $\begin{array}{c}\text { Mean } \\
\% \text { cover }\end{array}$ & SD & $\begin{array}{c}\text { Frequency } \\
(\%)\end{array}$ \\
\hline \multirow[t]{9}{*}{$\begin{array}{c}\text { CT-SB- } \\
\text { M-02 }\end{array}$} & Red top & Agrostis alba & 37.5 & 37.5 & 15 & 37.5 & 37.5 & 37.5 & 15 & 37.5 & 37.5 & 15 & 30.75 & 10.87 & 100 \\
\hline & $\begin{array}{c}\text { Slender } \\
\text { wheatgrass }\end{array}$ & $\begin{array}{c}\text { Agropyron } \\
\text { trachycaulum }\end{array}$ & 0 & 0 & 0 & 0 & 0 & 0 & 37.5 & 0 & 0 & 15 & 5.25 & 12.27 & 20 \\
\hline & Yarrow & $\begin{array}{c}\text { Achillea } \\
\text { millefolium }\end{array}$ & 0 & 0 & 15 & 2.5 & 0 & 0 & 0 & 0 & 15 & 0 & 3.25 & 6.24 & 30 \\
\hline & $\begin{array}{c}\text { Dwarf } \\
\text { fireweed }\end{array}$ & $\begin{array}{l}\text { Epilobium } \\
\text { latifolium }\end{array}$ & 0 & 0 & 0 & 0 & 0 & 0 & 0 & 0 & 2.5 & 2.5 & 0.5 & 1.05 & 20 \\
\hline & $\begin{array}{l}\text { Cudweed } \\
\text { sagewort }\end{array}$ & $\begin{array}{c}\text { Artemisia } \\
\text { Iudoviciana }\end{array}$ & 0 & 0 & 2.5 & 0 & 0 & 0 & 0 & 0 & 0 & 0 & 0.25 & 0.79 & 10 \\
\hline & Bare ground & & 62.5 & 15 & 85 & 15 & 37.5 & 37.5 & 15 & 37.5 & 62.5 & 62.5 & 43 & 24.38 & \\
\hline & Rock & & 2.5 & 2.5 & 2.5 & 2.5 & 2.5 & 2.5 & 2.5 & 2.5 & 2.5 & 2.5 & 2.5 & 0.00 & \\
\hline & Litter & & 15 & 62.5 & 2.5 & 62.5 & 37.5 & 37.5 & 62.5 & 37.5 & 15 & 15 & 34.75 & 22.47 & \\
\hline & & Total Live & 37.5 & 37.5 & 32.5 & 40 & 37.5 & 37.5 & 52.5 & 37.5 & 55 & 32.5 & 40 & & \\
\hline \multirow[t]{6}{*}{$\begin{array}{c}\text { CT-SB- } \\
\text { M-03 }\end{array}$} & Red top & Agrostis alba & 62.5 & 62.5 & 15 & 2.5 & 15 & 15 & 15 & 15 & 15 & 15 & 23.25 & 21.05 & 100 \\
\hline & $\begin{array}{c}\text { Slender } \\
\text { wheatgrass }\end{array}$ & $\begin{array}{c}\text { Agropyron } \\
\text { trachycaulum }\end{array}$ & 0 & 0 & 0 & 15 & 15 & 0 & 0 & 0 & 0 & 0 & 3 & 6.32 & 20 \\
\hline & $\begin{array}{c}\text { Western } \\
\text { wheatgrass }\end{array}$ & $\begin{array}{c}\text { Agropyron } \\
\text { smithii }\end{array}$ & 0 & 0 & 0 & 15 & 0 & 0 & 0 & 0 & 0 & 0 & 1.5 & 4.74 & 10 \\
\hline & Idaho fescue & $\begin{array}{c}\text { Festuca } \\
\text { idahoensis }\end{array}$ & 0 & 0 & 0 & 0 & 2.5 & 2.5 & 2.5 & 0 & 0 & 0 & 0.75 & 1.21 & 30 \\
\hline & Willow & Salix spp. & 0 & 0 & 0 & 0 & 0 & 2.5 & 0 & 2.5 & 0 & 0 & 0.5 & 1.05 & 20 \\
\hline & $\begin{array}{c}\text { Dwarf } \\
\text { fireweed }\end{array}$ & $\begin{array}{l}\text { Epilobium } \\
\text { latifolium }\end{array}$ & 0 & 0 & 0 & 15 & 0 & 0 & 0 & 0 & 0 & 0 & 1.5 & 4.74 & 10 \\
\hline
\end{tabular}


Table 30. Continued.

\begin{tabular}{|c|c|c|c|c|c|c|c|c|c|c|c|c|c|c|c|}
\hline & & Frame \# & 1 & 2 & 3 & 4 & 5 & 6 & 7 & 8 & 9 & 10 & & & \\
\hline \multirow[t]{8}{*}{$\begin{array}{c}\text { Transect } \\
\text { ID* }^{\star}\end{array}$} & $\begin{array}{l}\text { Common } \\
\text { Name }\end{array}$ & Species Name & $\begin{array}{c}\text { Mid } \\
\text { point }\end{array}$ & $\begin{array}{c}\text { Mid } \\
\text { point }\end{array}$ & $\begin{array}{c}\text { Mid } \\
\text { point }\end{array}$ & $\begin{array}{c}\text { Mid } \\
\text { point }\end{array}$ & $\begin{array}{c}\text { Mid } \\
\text { point }\end{array}$ & $\begin{array}{c}\text { Mid } \\
\text { point }\end{array}$ & $\begin{array}{c}\text { Mid } \\
\text { point }\end{array}$ & $\begin{array}{l}\text { Mid } \\
\text { point }\end{array}$ & $\begin{array}{l}\text { Mid } \\
\text { point }\end{array}$ & $\begin{array}{l}\text { Mid } \\
\text { point }\end{array}$ & $\begin{array}{c}\text { Mean } \\
\% \text { cover }\end{array}$ & SD & $\begin{array}{c}\text { Frequency } \\
(\%)\end{array}$ \\
\hline & Yarrow & Achillea millefolium & 0 & 0 & 0 & 0 & 2.5 & 15 & 15 & 15 & 15 & 15 & 7.75 & 7.68 & 60 \\
\hline & $\begin{array}{l}\text { White } \\
\text { clover }\end{array}$ & Trifolium repens & 0 & 0 & 0 & 0 & 0 & 2.5 & 37.5 & 2.5 & 0 & 0 & 4.25 & 11.73 & 30 \\
\hline & $\begin{array}{l}\text { Cudweed } \\
\text { sagewort }\end{array}$ & $\begin{array}{c}\text { Artemisia } \\
\text { ludoviciana }\end{array}$ & 0 & 0 & 0 & 0 & 0 & 2.5 & 0 & 0 & 0 & 0 & 0.25 & 0.79 & 10 \\
\hline & $\begin{array}{c}\text { Bare } \\
\text { ground }\end{array}$ & & 15 & 37.5 & 62.5 & 62.5 & 62.5 & 37.5 & 37.5 & 62.5 & 37.5 & 62.5 & 47.75 & 16.93 & \\
\hline & Rock & & 2.5 & 2.5 & 37.5 & 15 & 15 & 37.5 & 15 & 15 & 37.5 & 37.5 & 21.5 & 14.59 & \\
\hline & Litter & & 37.5 & 37.5 & 15 & 15 & 15 & 15 & 2.5 & 2.5 & 15 & 2.5 & 15.75 & 12.80 & \\
\hline & & Total Live & 62.5 & 62.5 & 15 & 47.5 & 35 & 40 & 70 & 35 & 30 & 30 & 42.75 & & \\
\hline \multirow[t]{5}{*}{$\begin{array}{c}\text { CT-SB- } \\
\text { P-01 }\end{array}$} & Red top & Agrostis alba & 15 & 2.5 & 2.5 & 0 & 0 & 0 & 0 & 0 & 0 & 0 & 2 & 4.68 & 30 \\
\hline & $\begin{array}{c}\text { Bare } \\
\text { Ground }\end{array}$ & & 85 & 85 & 85 & 85 & 62.5 & 85 & 85 & 85 & 85 & 85 & 82.75 & 7.12 & \\
\hline & Rock & & 2.5 & 2.5 & 15 & 2.5 & 2.5 & 15 & 2.5 & 2.5 & 2.5 & 15 & 6.25 & 6.04 & \\
\hline & Litter & & 2.5 & 15 & 15 & 15 & 37.5 & 15 & 15 & 15 & 15 & 2.5 & 14.75 & 9.53 & \\
\hline & & Total Live & 15 & 2.5 & 2.5 & 0 & 0 & 0 & 0 & 0 & 0 & 0 & 2 & & \\
\hline \multirow[t]{6}{*}{$\begin{array}{c}\text { CT-SB- } \\
\mathrm{P}-02 \\
\end{array}$} & Red top & Agrostis alba & 0 & 0 & 0 & 0 & 15 & 0 & 0 & 15 & 2.5 & 2.5 & 3.5 & 6.15 & 40 \\
\hline & Horsetail & Equisetum arvense & 0 & 0 & 0 & 0 & 0 & 0 & 0 & 0 & 2.5 & 15 & 1.75 & 4.72 & 20 \\
\hline & $\begin{array}{l}\text { Bare } \\
\text { ground }\end{array}$ & & 97.5 & 85 & 97.5 & 85 & 85 & 85 & 97.5 & 62.5 & 97.5 & 62.5 & 85.5 & 13.48 & \\
\hline & Rock & & 2.5 & 2.5 & 2.5 & 2.5 & 2.5 & 15 & 2.5 & 2.5 & 2.5 & 37.5 & 7.25 & 11.33 & \\
\hline & Litter & & 2.5 & 15 & 2.5 & 15 & 15 & 2.5 & 2.5 & 37.5 & 2.5 & 2.5 & 9.75 & 11.39 & \\
\hline & & Total Live & 0 & 0 & 0 & 0 & 15 & 0 & 0 & 15 & 5 & 17.5 & 5.25 & & \\
\hline
\end{tabular}


Table 30. Continued.

\begin{tabular}{|c|c|c|c|c|c|c|c|c|c|c|c|c|c|c|c|}
\hline & Frame \# & 1 & 2 & 3 & 4 & 5 & 6 & 7 & 8 & 9 & 10 & & \\
\hline $\begin{array}{c}\text { Transect } \\
\text { ID** }\end{array}$ & $\begin{array}{c}\text { Common } \\
\text { Name }\end{array}$ & Species Name & $\begin{array}{c}\text { Mid } \\
\text { point }\end{array}$ & $\begin{array}{c}\text { Mid } \\
\text { point }\end{array}$ & $\begin{array}{c}\text { Mid } \\
\text { point }\end{array}$ & $\begin{array}{c}\text { Mid } \\
\text { point }\end{array}$ & $\begin{array}{c}\text { Mid } \\
\text { point }\end{array}$ & $\begin{array}{c}\text { Mid } \\
\text { point }\end{array}$ & $\begin{array}{c}\text { Mid } \\
\text { point }\end{array}$ & $\begin{array}{c}\text { Mid } \\
\text { point }\end{array}$ & $\begin{array}{c}\text { Mid } \\
\text { point }\end{array}$ & $\begin{array}{c}\text { Mid } \\
\text { point }\end{array}$ & $\begin{array}{c}\text { Mean } \\
\% c o v e r\end{array}$ & SD & $\begin{array}{c}\text { Frequency } \\
\text { (\%) }\end{array}$ \\
\hline $\begin{array}{c}\text { CT-SB- } \\
\text { P-03 }\end{array}$ & Red top & Agrostis alba & 0 & 0 & 2.5 & 2.5 & 2.5 & 0 & 2.5 & 0 & 15 & 0 & 2.5 & 4.56 & 50 \\
\hline & $\begin{array}{c}\text { Dwarf } \\
\text { fireweed }\end{array}$ & $\begin{array}{c}\text { Epilobium } \\
\text { latifolium }\end{array}$ & 0 & 0 & 2.5 & 0 & 0 & 0 & 0 & 2.5 & 0 & 2.5 & 0.75 & 1.21 & 30 \\
\hline & Yarrow & $\begin{array}{c}\text { Achillea } \\
\text { millefolium }\end{array}$ & 0 & 0 & 0 & 15 & 0 & 2.5 & 0 & 15 & 0 & 0 & 3.25 & 6.24 & 30 \\
\hline & $\begin{array}{c}\text { Cudweed } \\
\text { sagewort }\end{array}$ & $\begin{array}{c}\text { Artemisia } \\
\text { ludoviciana }\end{array}$ & 0 & 0 & 0 & 0 & 0 & 0 & 0 & 0 & 0 & 2.5 & 0.25 & 0.79 & 10 \\
\hline Bare Ground & & 85 & 85 & 97.5 & 85 & 85 & 62.5 & 97.5 & 85 & 85 & 97.5 & 86.5 & 10.29 & \\
\hline & Rock & & 2.5 & 15 & 2.5 & 2.5 & 15 & 37.5 & 2.5 & 2.5 & 2.5 & 2.5 & 8.5 & 11.44 & \\
\hline & Litter & & 15 & 2.5 & 2.5 & 2.5 & 15 & 15 & 2.5 & 2.5 & 15 & 2.5 & 7.5 & 6.45 & \\
\hline
\end{tabular}

* $\mathrm{CT}=$ Comet, $\mathrm{SB}=$ Subirrigated, $\mathrm{OV}=$ Overflow, $\mathrm{G}=\mathrm{Good}, \mathrm{M}=$ Moderate, $\mathrm{P}=$ Poor 
Table 31. Production data from the Comet Mine

\begin{tabular}{|l|c|c|c|c|c|c|c|c|c|c|c|c|c|c|}
\hline & $\begin{array}{c}\text { Life } \\
\text { Form }\end{array}$ & $\begin{array}{c}\text { Frame } \\
1\end{array}$ & $\begin{array}{c}\text { Frame } \\
2\end{array}$ & $\begin{array}{c}\text { Frame } \\
3\end{array}$ & $\begin{array}{c}\text { Frame } \\
4\end{array}$ & $\begin{array}{c}\text { Frame } \\
5\end{array}$ & $\begin{array}{c}\text { Frame } \\
6\end{array}$ & $\begin{array}{c}\text { Frame } \\
7\end{array}$ & $\begin{array}{c}\text { Frame } \\
8\end{array}$ & $\begin{array}{c}\text { Frame } \\
9\end{array}$ & $\begin{array}{c}\text { Frame } \\
10\end{array}$ & Mean & $\begin{array}{c}\text { Standard } \\
\text { Deviation }\end{array}$ & $\begin{array}{c}\text { Total } \\
\text { Production }\end{array}$ \\
\hline Transect ID* & & Wt (g) & Wt (g) & Wt (g) & Wt (g) & Wt (g) & Wt (g) & Wt (g) & Wt (g) & Wt (g) & Wt (g) & (g) & & kg/ha \\
\hline CT-OV-G-01 & Grass & 6 & 7.34 & 4.9 & 4.82 & 6.98 & 4.2 & 9.55 & 8.2 & 4.97 & 17.26 & 7.42 & 3.85 & 1187.52 \\
\hline & Forb & 0 & 0 & 0 & 0 & 0 & 0 & 0 & 0 & 0 & 0 & 0.00 & 0.00 & 0.00 \\
\hline & Shrub & 0 & 0 & 0 & 0 & 0 & 0 & 0 & 0 & 0 & 0 & 0.00 & 0.00 & 0.00 \\
\hline & Total & 6 & 7.34 & 4.9 & 4.82 & 6.98 & 4.2 & 9.55 & 8.2 & 4.97 & 17.26 & 7.42 & 3.85 & 1187.52 \\
\hline & & & & & & & & & & & & & & \\
\hline CT-OV-G-02 & Grass & 6.08 & 27.06 & 12.47 & 13.22 & 3.42 & 6.22 & 2.81 & 10.83 & 13.04 & 6.5 & 10.17 & 7.10 & 1626.40 \\
\hline & Forb & 0 & 0 & 0 & 0 & 0 & 0 & 0 & 0 & 0.35 & 0 & 0.04 & 0.11 & 5.60 \\
\hline & Shrub & 0 & 0 & 0 & 0 & 0 & 0 & 0 & 0 & 0 & 0 & 0.00 & 0.00 & 0.00 \\
\hline & Total & 6.08 & 27.06 & 12.47 & 13.22 & 3.42 & 6.22 & 2.81 & 10.83 & 13.39 & 6.5 & 10.20 & 7.12 & 1632.00 \\
\hline & & & & & & & & & & & & & & \\
\hline CT-OV-G-03 & Grass & 20.63 & 28.29 & 12.06 & 20 & 4.17 & 60.76 & 49.19 & 4.64 & 21.4 & 3.55 & 22.47 & 19.27 & 3595.04 \\
\hline & Forb & 0.07 & 0 & 0 & 0 & 0.09 & 0 & 0 & 0 & 0 & 0 & 0.02 & 0.03 & 2.56 \\
\hline & Shrub & 0 & 0 & 0 & 0 & 0 & 0 & 0 & 0 & 0 & 0 & 0.00 & 0.00 & 0.00 \\
\hline & Total & 20.7 & 28.29 & 12.06 & 20 & 4.26 & 60.76 & 49.19 & 4.64 & 21.4 & 3.55 & 22.49 & 19.26 & 3597.60 \\
\hline & & & & & & & & & & & & & & \\
\hline
\end{tabular}


Table 31. Continued.

\begin{tabular}{|c|c|c|c|c|c|c|c|c|c|c|c|c|c|c|}
\hline & $\begin{array}{c}\text { Life } \\
\text { Form }\end{array}$ & $\begin{array}{c}\text { Frame } \\
1 \\
\end{array}$ & \begin{tabular}{|c} 
Frame \\
2 \\
\end{tabular} & \begin{tabular}{|c|} 
Frame \\
3 \\
\end{tabular} & \begin{tabular}{|c|} 
Frame \\
4
\end{tabular} & \begin{tabular}{|c|} 
Frame \\
5 \\
\end{tabular} & \begin{tabular}{|c|} 
Frame \\
6 \\
\end{tabular} & \begin{tabular}{|c|} 
Frame \\
7 \\
\end{tabular} & \begin{tabular}{|c} 
Frame \\
8 \\
\end{tabular} & \begin{tabular}{|c|} 
Frame \\
9
\end{tabular} & $\begin{array}{c}\text { Frame } \\
10 \\
\end{array}$ & Mean & $\begin{array}{c}\text { Standard } \\
\text { Deviation }\end{array}$ & $\begin{array}{c}\text { Total } \\
\text { Production }\end{array}$ \\
\hline Transect ID* & & Wt (g) & Wt (g) & Wt (g) & Wt (g) & Wt (g) & Wt (g) & Wt (g) & Wt (g) & Wt (g) & Wt (g) & (g) & & $\mathrm{kg} / \mathrm{ha}$ \\
\hline \multirow[t]{4}{*}{ CT-OV-M-02 } & Grass & 2.29 & 11.62 & 1.56 & 0.81 & 1.16 & 2.45 & 3.39 & 3.28 & 4.39 & 1.92 & 3.29 & 3.12 & 525.92 \\
\hline & Forb & 0.13 & 0.84 & 0 & 0.06 & 0 & 0 & 0 & 0 & 0 & 0 & 0.10 & 0.26 & 16.48 \\
\hline & Shrub & 0 & 0 & 0 & 0 & 0 & 0 & 0 & 0 & 0 & 0 & 0.00 & 0.00 & 0.00 \\
\hline & Total & 2.42 & 12.46 & 1.56 & 0.87 & 1.16 & 2.45 & 3.39 & 3.28 & 4.39 & 1.92 & 3.39 & 3.37 & 542.40 \\
\hline \multirow[t]{4}{*}{ CT-OV-M-03 } & Grass & 1.19 & 1.38 & 1.66 & 0.95 & 4.74 & 3 & 0.97 & 1.46 & 1.56 & 2.34 & 1.93 & 1.17 & 308.00 \\
\hline & Forb & 0 & 0 & 0 & 0 & 0 & 0.1 & 0.17 & 0 & 0 & 0 & 0.03 & 0.06 & 4.32 \\
\hline & Shrub & 0 & 0 & 0 & 0 & 0 & 0 & 0 & 0 & 0 & 0 & 0.00 & 0.00 & 0.00 \\
\hline & Total & 1.19 & 1.38 & 1.66 & 0.95 & 4.74 & 3.1 & 1.14 & 1.46 & 1.56 & 2.34 & 1.95 & 1.17 & 312.32 \\
\hline \multirow[t]{4}{*}{ CT-OV-P-01 } & Grass & 0 & 0 & 0 & 0 & 0 & 0 & 0 & 0 & 0 & 0 & 0.00 & 0.00 & 0.00 \\
\hline & Forb & 0 & 0 & 0 & 0 & 0 & 0 & 0 & 0 & 0 & 0 & 0.00 & 0.00 & 0.00 \\
\hline & Shrub & 0 & 0 & 0 & 0 & 0 & 0 & 0 & 0 & 0 & 0 & 0.00 & 0.00 & 0.00 \\
\hline & Total & 0 & 0 & 0 & 0 & 0 & 0 & 0 & 0 & 0 & 0 & 0.00 & 0.00 & 0.00 \\
\hline \multirow[t]{4}{*}{ CT-OV-P-02 } & Grass & 0 & 0 & 0 & 0 & 0 & 0 & 0 & 0 & 0 & 0 & 0.00 & 0.00 & 0.00 \\
\hline & Forb & 0 & 0 & 0 & 0 & 0 & 0 & 0 & 0 & 0 & 0 & 0.00 & 0.00 & 0.00 \\
\hline & Shrub & 0 & 0 & 0 & 0 & 0 & 0 & 0 & 0 & 0 & 0 & 0.00 & 0.00 & 0.00 \\
\hline & Total & 0 & 0 & 0 & 0 & 0 & 0 & 0 & 0 & 0 & 0 & 0.00 & 0.00 & 0.00 \\
\hline
\end{tabular}


Table 31. Continued.

\begin{tabular}{|c|c|c|c|c|c|c|c|c|c|c|c|c|c|c|}
\hline & $\begin{array}{l}\text { Life } \\
\text { Form }\end{array}$ & \begin{tabular}{|c|} 
Frame \\
1 \\
\end{tabular} & \begin{tabular}{|c|} 
Frame \\
2 \\
\end{tabular} & \begin{tabular}{|c|} 
Frame \\
3 \\
\end{tabular} & \begin{tabular}{|c|} 
Frame \\
4 \\
\end{tabular} & \begin{tabular}{|c|} 
Frame \\
5 \\
\end{tabular} & \begin{tabular}{|c|} 
Frame \\
6 \\
\end{tabular} & \begin{tabular}{|c|} 
Frame \\
7 \\
\end{tabular} & \begin{tabular}{|c|} 
Frame \\
8 \\
\end{tabular} & \begin{tabular}{|c|} 
Frame \\
9 \\
\end{tabular} & $\begin{array}{c}\text { Frame } \\
10 \\
\end{array}$ & Mean & \begin{tabular}{|c|} 
Standard \\
Deviation \\
\end{tabular} & \begin{tabular}{|c|} 
Total \\
Production \\
\end{tabular} \\
\hline Transect ID* & & Wt (g) & Wt (g) & Wt (g) & Wt (g) & Wt (g) & Wt (g) & Wt (g) & Wt (g) & Wt (g) & Wt (g) & (g) & & $\mathrm{kg} / \mathrm{ha}$ \\
\hline \multirow[t]{4}{*}{ CT-OV-P-03 } & Grass & 0 & 0 & 0 & 0 & 0.15 & 0 & 1.28 & 0 & 0 & 0 & 0.14 & 0.40 & 22.88 \\
\hline & Forb & 0 & 0 & 0 & 0 & 0 & 0 & 0 & 0 & 0 & 0 & 0.00 & 0.00 & 0.00 \\
\hline & Shrub & 0 & 0 & 0 & 0 & 0 & 0 & 0 & 0 & 0 & 0 & 0.00 & 0.00 & 0.00 \\
\hline & Total & 0 & 0 & 0 & 0 & 0.15 & 0 & 1.28 & 0 & 0 & 0 & 0.14 & 0.40 & 22.88 \\
\hline \multirow[t]{4}{*}{ CT-SB-G-01 } & Grass & 17.54 & 8.55 & 10.28 & 9.83 & 16.19 & 2.12 & 5.08 & 5.57 & 5.44 & 10.18 & 9.08 & 4.89 & 1452.48 \\
\hline & Forb & 0 & 0 & 0 & 0 & 0 & 0 & 0 & 0 & 0 & 0 & 0.00 & 0.00 & 0.00 \\
\hline & Shrub & & 0 & 0 & 0 & 0 & 0 & 0 & 0 & 0 & 0 & 0.00 & 0.00 & 0.00 \\
\hline & Total & 17.54 & 8.55 & \begin{tabular}{|l|}
10.28 \\
\end{tabular} & 9.83 & 16.19 & 2.12 & 5.08 & 5.57 & 5.44 & 10.18 & 9.08 & 4.89 & 1452.48 \\
\hline \multirow[t]{4}{*}{ CT-SB-G-02 } & Grass & 10.97 & 11.44 & 9.23 & 1.94 & 1.81 & 5.76 & 16.46 & 9.06 & 10.41 & 20.62 & 9.77 & 5.86 & 1563.20 \\
\hline & Forb & 0.07 & 0.28 & 0.42 & 0 & 0 & 0 & 0 & 0.54 & 0 & 0.5 & 0.18 & 0.23 & 28.96 \\
\hline & Shrub & 0 & 0 & 0 & 0 & 0 & 0 & 0 & 0 & 0 & 0 & 0.00 & 0.00 & 0.00 \\
\hline & Total & 11.04 & 11.72 & 9.65 & 1.94 & 1.81 & 5.76 & 16.46 & 9.6 & 10.41 & 21.12 & 9.95 & 5.96 & 1592.16 \\
\hline \multirow[t]{4}{*}{ CT-SB-G-03 } & Grass & 18.05 & 10.04 & 13.74 & 23.03 & 34.88 & 11.97 & 16.61 & 5.28 & 15.5 & 16.42 & 16.55 & 8.03 & 2648.32 \\
\hline & Forb & 0.46 & 0 & 0 & 0 & 0 & 0 & 0.36 & 0 & 1.27 & 0.43 & 0.25 & 0.41 & 40.32 \\
\hline & Shrub & 0 & 0 & 0 & 0 & 0 & 0 & 0 & 0 & 0 & 0 & 0.00 & 0.00 & 0.00 \\
\hline & Total & 18.51 & 10.04 & 13.74 & 23.03 & 34.88 & 11.97 & 16.97 & 5.28 & 16.77 & 16.85 & 16.80 & 8.03 & 2688.64 \\
\hline
\end{tabular}


Table 31. Continued.

\begin{tabular}{|c|c|c|c|c|c|c|c|c|c|c|c|c|c|c|}
\hline & Life & Frame & Frame & Frame & Frame & Frame & Frame & Frame & Frame & Frame & Frame & Mean & $\begin{array}{c}\text { Standard } \\
\text { Deviation }\end{array}$ & $\begin{array}{c}\text { Total } \\
\text { Production }\end{array}$ \\
\hline Transect ID* & & Wt (g) & Wt (g) & Wt (g) & Wt (g) & Wt (g) & Wt (g) & Wt (g) & Wt (g) & Wt (g) & Wt (g) & (g) & & kg/ha \\
\hline CT-SB-M-01 & Grass & 2.2 & 0.49 & 7.19 & 6.01 & 0.26 & 14.65 & 4.56 & 2.12 & 1.96 & 1.65 & 4.11 & 4.35 & 657.44 \\
\hline & Forb & 0 & 0.05 & 0.08 & 0 & 0 & 0.04 & 0 & 0 & 0.14 & 0.12 & 0.04 & 0.05 & 6.88 \\
\hline & Shrub & 0 & 0 & 0 & 0 & 0 & 0 & 0 & 0 & 0 & 0 & 0.00 & 0.00 & 0.00 \\
\hline & Total & 2.2 & 0.54 & 7.27 & 6.01 & 0.26 & 14.69 & 4.56 & 2.12 & 2.1 & 1.77 & 4.15 & 4.35 & 664.32 \\
\hline & & & & & & & & & & & & & & \\
\hline CT-SB-M-02 & Grass & 5.54 & 7.3 & 1.48 & 9.53 & 4.31 & 3 & 5.94 & 5.19 & 3.5 & 6.47 & 5.23 & 2.30 & 836.16 \\
\hline & Forb & 0 & 0 & 0.74 & 0 & 0 & 0 & 0 & 0 & 0.1 & 0.13 & 0.10 & 0.23 & 15.52 \\
\hline & Shrub & 0 & 0 & 0 & 0 & 0 & 0 & 0 & 0 & 0 & 0 & 0.00 & 0.00 & 0.00 \\
\hline & Total & 5.54 & 7.3 & 2.22 & 9.53 & 4.31 & 3 & 5.94 & 5.19 & 3.6 & 6.6 & 5.32 & 2.18 & 851.68 \\
\hline & & & & & & & & & & & & & & \\
\hline CT-SB-M-03 & Grass & 11.06 & 5.16 & 1.53 & 3 & 0.33 & 7.48 & 1.76 & 3.51 & 1.2 & 0.47 & 3.55 & 3.45 & 568.00 \\
\hline & Forb & 0 & 0 & 0 & 0 & 0 & 0.38 & 1.71 & 0.59 & 0.61 & 0.47 & 0.38 & 0.54 & 60.16 \\
\hline & Shrub & 0 & 0 & 0 & 0 & 0 & 0 & 0 & 0 & 0 & 0 & 0.00 & 0.00 & 0.00 \\
\hline & Total & 11.06 & 5.16 & 1.53 & 3 & 0.33 & 7.86 & 3.47 & 4.1 & 1.81 & 0.94 & 3.93 & 3.35 & 628.16 \\
\hline & & & & & & & & & & & & & & \\
\hline & Grass & 0.47 & 0 & 0 & 0 & 0 & 0 & 0 & 0 & 0 & 0 & 0.05 & 0.15 & 7.52 \\
\hline & Forb & 0 & 0 & 0 & 0 & 0 & 0 & 0 & 0 & 0 & 0 & 0.00 & 0.00 & 0.00 \\
\hline & Shrub & 0 & 0 & 0 & 0 & 0 & 0 & 0 & 0 & 0 & 0 & 0.00 & 0.00 & 0.00 \\
\hline & Total & 0.47 & 0 & 0 & 0 & 0 & 0 & 0 & 0 & 0 & 0 & 0.05 & 0.15 & 7.52 \\
\hline & & & & & & & & & & & & & & \\
\hline & Grass & 0 & 0 & 0 & 0 & 0.45 & 0 & 0 & 1.15 & 0 & 0 & 0.16 & 0.38 & 25.60 \\
\hline & Forb & 0 & 0 & 0 & 0 & 0 & 0 & 0 & 0 & 0 & 0.2 & 0.02 & 0.06 & 3.20 \\
\hline Shrub & 0 & 0 & 0 & 0 & 0 & 0 & 0 & 0 & 0 & 0 & 0.00 & 0.00 & 0.00 \\
\hline & Total & 0 & 0 & 0 & 0 & 0 & 0 & 0 & 0 & 0 & 1.39 & 0.14 & 0.44 & 22.24 \\
\hline
\end{tabular}


Table 31. Continued.

\begin{tabular}{|c|c|c|c|c|c|c|c|c|c|c|c|c|c|c|}
\hline & $\begin{array}{l}\text { Life } \\
\text { Form }\end{array}$ & $\begin{array}{c}\text { Frame } \\
1 \\
\end{array}$ & \begin{tabular}{|c|} 
Frame \\
2 \\
\end{tabular} & \begin{tabular}{|c|} 
Frame \\
3 \\
\end{tabular} & \begin{tabular}{|c|} 
Frame \\
4
\end{tabular} & \begin{tabular}{|c|} 
Frame \\
5 \\
\end{tabular} & \begin{tabular}{|c|} 
Frame \\
6 \\
\end{tabular} & \begin{tabular}{|c|} 
Frame \\
7 \\
\end{tabular} & \begin{tabular}{|c|} 
Frame \\
8 \\
\end{tabular} & \begin{tabular}{|c|} 
Frame \\
9 \\
\end{tabular} & $\begin{array}{c}\text { Frame } \\
10 \\
\end{array}$ & Mean & \begin{tabular}{|c|} 
Standard \\
Deviation \\
\end{tabular} & $\begin{array}{c}\text { Total } \\
\text { Production } \\
\end{array}$ \\
\hline Transect ID* & & Wt (g) & Wt (g) & Wt (g) & Wt (g) & Wt (g) & Wt (g) & Wt (g) & Wt (g) & Wt (g) & Wt (g) & (g) & & kg/ha \\
\hline \multirow[t]{4}{*}{ CT-SB-P-03 } & Grass & 0 & 0 & 0 & 0 & 0 & 0 & 0 & 0 & 1.64 & 0 & 0.16 & 0.52 & 26.24 \\
\hline & Forb & 0 & 0 & 0 & 0.85 & 0 & 0 & 0 & 0.72 & 0 & 0 & 0.16 & 0.33 & 25.12 \\
\hline & Shrub & 0 & 0 & 0 & 0 & 0 & 0 & 0 & 0 & 0 & 0 & 0.00 & 0.00 & 0.00 \\
\hline & Total & 0 & 0 & 0 & 0.85 & 0 & 0 & 0 & 0.72 & 1.64 & 0 & 0.32 & 0.57 & 51.36 \\
\hline
\end{tabular}

* $\mathrm{CT}=$ Comet, $\mathrm{SB}=$ Subirrigated, $\mathrm{OV}=$ Overflow, $\mathrm{G}=\mathrm{Good}, \mathrm{M}=$ Moderate, $\mathrm{P}=$ Poor 
Table 32. Field canopy cover data, total percent cover by species and sample area, standard deviation and species frequency from High Ore Creek.

\begin{tabular}{|c|c|c|c|c|c|c|c|c|c|c|c|c|c|c|c|}
\hline & & Frame \# & 1 & 2 & 3 & 4 & 5 & 6 & 7 & 8 & 9 & 10 & & & \\
\hline $\begin{array}{c}\text { Transect } \\
\text { ID* }\end{array}$ & $\begin{array}{l}\text { Common } \\
\text { Name }\end{array}$ & Species Name & $\begin{array}{l}\text { Mid } \\
\text { point }\end{array}$ & $\begin{array}{c}\text { Mid } \\
\text { point }\end{array}$ & $\begin{array}{c}\text { Mid } \\
\text { point }\end{array}$ & $\begin{array}{l}\text { Mid } \\
\text { point }\end{array}$ & $\begin{array}{l}\text { Mid } \\
\text { point }\end{array}$ & $\begin{array}{c}\text { Mid } \\
\text { point }\end{array}$ & $\begin{array}{l}\text { Mid } \\
\text { point }\end{array}$ & $\begin{array}{l}\text { Mid } \\
\text { point }\end{array}$ & $\begin{array}{l}\text { Mid } \\
\text { point }\end{array}$ & $\begin{array}{c}\text { Mid } \\
\text { point }\end{array}$ & $\begin{array}{c}\text { Mean } \\
\% \text { cover }\end{array}$ & SD & $\begin{array}{c}\text { Frequency } \\
(\%)\end{array}$ \\
\hline \multirow[t]{10}{*}{$\begin{array}{c}\text { HOC-P- } \\
01\end{array}$} & $\begin{array}{l}\text { Idaho } \\
\text { fescue }\end{array}$ & $\begin{array}{c}\text { Festuca } \\
\text { idahoensis }\end{array}$ & 0 & 15 & 2.5 & 0 & 15 & 15 & 2.5 & 15 & 2.5 & 2.5 & 7 & 6.952 & 80 \\
\hline & Red top & Agrostis alba & 0 & 2.5 & 0 & 0 & 0 & 37.5 & 2.5 & 2.5 & 2.5 & 0 & 4.75 & 11.57 & 50 \\
\hline & $\begin{array}{c}\text { Yellow } \\
\text { sweetclover }\end{array}$ & $\begin{array}{l}\text { Melilotus } \\
\text { officinalis }\end{array}$ & 62.5 & 37.5 & 15 & 85 & 37.5 & 37.5 & 62.5 & 15 & 2.5 & 15 & 37 & 26.35 & 100 \\
\hline & Yarrow & $\begin{array}{c}\text { Achillea } \\
\text { millefolium }\end{array}$ & 37.5 & 37.5 & 62.5 & 37.5 & 37.5 & 15 & 37.5 & 37.5 & 62.5 & 37.5 & 40.25 & 13.67 & 100 \\
\hline & Dandelion & $\begin{array}{c}\text { Taraxacum } \\
\text { officinale }\end{array}$ & 2.5 & 0 & 0 & 0 & 0 & 0 & 0 & 0 & 0 & 0 & 0.25 & 0.791 & 10 \\
\hline & $\begin{array}{c}\text { Dwarf } \\
\text { fireweed }\end{array}$ & $\begin{array}{l}\text { Epilobium } \\
\text { latifolium }\end{array}$ & 0 & 0 & 0 & 0 & 0 & 0 & 0 & 0 & 0 & 2.5 & 0.25 & 0.791 & 10 \\
\hline & Bare ground & & 15 & 15 & 15 & 2.5 & 37.5 & 15 & 2.5 & 15 & 37.5 & 37.5 & 19.25 & 13.54 & \\
\hline & Rock & & 2.5 & 2.5 & 2.5 & 2.5 & 2.5 & 2.5 & 2.5 & 2.5 & 2.5 & 2.5 & 2.5 & 0 & \\
\hline & Litter & & 2.5 & 15 & 37.5 & 15 & 15 & 2.5 & 15 & 2.5 & 15 & 15 & 13.5 & 10.29 & \\
\hline & & Total Live & 103 & \begin{tabular}{|l|}
92.5 \\
\end{tabular} & 80 & 123 & 90 & 105 & 105 & 70 & 70 & 57.5 & 89.5 & & \\
\hline
\end{tabular}


Table 32. Continued.

\begin{tabular}{|c|c|c|c|c|c|c|c|c|c|c|c|c|c|c|c|}
\hline & & Frame \# & 1 & 2 & 3 & 4 & 5 & 6 & 7 & 8 & 9 & 10 & & & \\
\hline $\begin{array}{c}\text { Transect } \\
\text { ID* }\end{array}$ & $\begin{array}{l}\text { Common } \\
\text { Name }\end{array}$ & Species Name & $\begin{array}{c}\text { Mid } \\
\text { point }\end{array}$ & \begin{tabular}{|c|} 
Mid \\
point
\end{tabular} & $\begin{array}{c}\text { Mid } \\
\text { point }\end{array}$ & \begin{tabular}{|l} 
Mid \\
point
\end{tabular} & $\begin{array}{c}\text { Mid } \\
\text { point }\end{array}$ & \begin{tabular}{|c|} 
Mid \\
point
\end{tabular} & $\begin{array}{l}\text { Mid } \\
\text { point }\end{array}$ & $\begin{array}{l}\text { Mid } \\
\text { point }\end{array}$ & $\begin{array}{l}\text { Mid } \\
\text { point }\end{array}$ & $\begin{array}{c}\text { Mid } \\
\text { point }\end{array}$ & $\begin{array}{c}\text { Mean } \\
\% \text { cover }\end{array}$ & SD & $\begin{array}{c}\text { Frequency } \\
(\%)\end{array}$ \\
\hline \multirow[t]{12}{*}{$\begin{array}{l}\mathrm{HOC}-\mathrm{P}- \\
02\end{array}$} & $\begin{array}{l}\text { Idaho } \\
\text { fescue }\end{array}$ & $\begin{array}{c}\text { Festuca } \\
\text { idahoensis }\end{array}$ & 37.5 & 15 & 15 & 37.5 & 37.5 & 2.5 & 37.5 & 15 & 15 & 15 & 22.75 & 13.25 & 100 \\
\hline & $\begin{array}{l}\text { Bluebunch } \\
\text { wheatgrass }\end{array}$ & $\begin{array}{l}\text { Agropyron } \\
\text { spicatum }\end{array}$ & 15 & 0 & 37.5 & 0 & 15 & 2.5 & 0 & 0 & 0 & 0 & 7 & 12.35 & 40 \\
\hline & Red top & Agrostis alba & 0 & 2.5 & 0 & 0 & 0 & 0 & 0 & 0 & 0 & 0 & 0.25 & 0.791 & 10 \\
\hline & $\begin{array}{l}\text { Prarie } \\
\text { junegrass }\end{array}$ & $\begin{array}{c}\text { Koeleria } \\
\text { cristata }\end{array}$ & 0 & 0 & 0 & 15 & 0 & 0 & 0 & 0 & 0 & 0 & 1.5 & 4.743 & 10 \\
\hline & $\begin{array}{c}\text { Slender } \\
\text { wheatgrass }\end{array}$ & $\begin{array}{c}\text { Agropyron } \\
\text { trachycaulum }\end{array}$ & 0 & 0 & 0 & 0 & 2.5 & 0 & 2.5 & 15 & 0 & 0 & 2 & 4.684 & 30 \\
\hline & $\begin{array}{c}\text { Western } \\
\text { wheatgrass }\end{array}$ & $\begin{array}{c}\text { Agropyron } \\
\text { smithii }\end{array}$ & 0 & 0 & 0 & 0 & 0 & 0 & 0 & 0 & 0 & 15 & 1.5 & 4.743 & 10 \\
\hline & $\begin{array}{c}\text { Columbia } \\
\text { needlegrass }\end{array}$ & $\begin{array}{c}\text { Achnatherum } \\
\text { nelsonii }\end{array}$ & 0 & 0 & 0 & 0 & 0 & 0 & 0 & 0 & 0 & 2.5 & 0.25 & 0.791 & 10 \\
\hline & Yarrow & $\begin{array}{c}\text { Achillea } \\
\text { millefolium }\end{array}$ & 15 & 37.5 & 2.5 & 37.5 & 15 & 62.5 & 37.5 & 37.5 & 15 & 15 & 27.5 & 17.87 & 100 \\
\hline & Bare ground & & 15 & 62.5 & 62.5 & 15 & 15 & 15 & 15 & 15 & 85 & 37.5 & 33.75 & 26.67 & \\
\hline & Rock & & 2.5 & 2.5 & 2.5 & 2.5 & 2.5 & 15 & 2.5 & 2.5 & 2.5 & 2.5 & 3.75 & 3.953 & \\
\hline & Litter & & 37.5 & 15 & 15 & 37.5 & 37.5 & 15 & 37.5 & 37.5 & 2.5 & 37.5 & 27.25 & 13.72 & \\
\hline & & Total Live & 67.5 & 55 & 55 & 90 & 70 & 67.5 & 77.5 & 67.5 & 30 & 47.5 & 62.75 & & \\
\hline
\end{tabular}


Table 32. Continued.

\begin{tabular}{|c|c|c|c|c|c|c|c|c|c|c|c|c|c|c|c|}
\hline & & Frame \# & 1 & 2 & 3 & 4 & 5 & 6 & 7 & 8 & 9 & 10 & & & \\
\hline $\begin{array}{c}\text { Transect } \\
I^{*}\end{array}$ & $\begin{array}{l}\text { Common } \\
\text { Name }\end{array}$ & Species Name & $\begin{array}{l}\text { Mid } \\
\text { point }\end{array}$ & \begin{tabular}{|c|} 
Mid \\
point
\end{tabular} & $\begin{array}{l}\text { Mid } \\
\text { point }\end{array}$ & \begin{tabular}{|l} 
Mid \\
point
\end{tabular} & $\begin{array}{c}\text { Mid } \\
\text { point }\end{array}$ & \begin{tabular}{|c|} 
Mid \\
point
\end{tabular} & $\begin{array}{l}\text { Mid } \\
\text { point }\end{array}$ & $\begin{array}{l}\text { Mid } \\
\text { point }\end{array}$ & $\begin{array}{l}\text { Mid } \\
\text { point }\end{array}$ & $\begin{array}{c}\text { Mid } \\
\text { point }\end{array}$ & $\begin{array}{c}\text { Mean } \\
\% \text { cover }\end{array}$ & SD & $\begin{array}{c}\text { Frequency } \\
(\%)\end{array}$ \\
\hline \multirow[t]{13}{*}{$\begin{array}{c}\mathrm{HOC}-\mathrm{P}- \\
03\end{array}$} & $\begin{array}{l}\text { Idaho } \\
\text { fescue }\end{array}$ & $\begin{array}{c}\text { Festuca } \\
\text { idahoensis }\end{array}$ & 15 & 37.5 & 15 & 15 & 15 & 15 & 2.5 & 37.5 & 15 & 15 & 18.25 & 10.87 & 100 \\
\hline & $\begin{array}{c}\text { Prairie } \\
\text { junegrass }\end{array}$ & $\begin{array}{c}\text { Koeleria } \\
\text { cristata }\end{array}$ & 2.5 & 0 & 15 & 0 & 0 & 15 & 0 & 15 & 0 & 15 & 6.25 & 7.569 & 50 \\
\hline & \begin{tabular}{|c|} 
Bluebunch \\
wheatgrass
\end{tabular} & $\begin{array}{l}\text { Agropyron } \\
\text { spicatum }\end{array}$ & 2.5 & 0 & 15 & 15 & 15 & 0 & 0 & 0 & 15 & 0 & 6.25 & 7.569 & 50 \\
\hline & Red top & Agrostis alba & 2.5 & 0 & 0 & 0 & 0 & 0 & 2.5 & 2.5 & 0 & 0 & 0.75 & 1.208 & 30 \\
\hline & \begin{tabular}{|c|} 
Slender \\
wheatgrass
\end{tabular} & $\begin{array}{c}\text { Agropyron } \\
\text { trachycaulum }\end{array}$ & 0 & 0 & 15 & 2.5 & 0 & 0 & 0 & 0 & 15 & 2.5 & 3.5 & 6.146 & 40 \\
\hline & \begin{tabular}{|c|} 
Western \\
wheatgrass
\end{tabular} & $\begin{array}{l}\text { Agropyron } \\
\text { smithii }\end{array}$ & 0 & 0 & 0 & 0 & 0 & 15 & 0 & 0 & 0 & 2.5 & 1.75 & 4.721 & 20 \\
\hline & Yarrow & $\begin{array}{c}\text { Achillea } \\
\text { millefolium }\end{array}$ & 37.5 & 0 & 2.5 & 15 & 2.5 & 37.5 & 62.5 & 15 & 2.5 & 15 & 19 & 20.55 & 90 \\
\hline & Dandelion & $\begin{array}{l}\text { Taraxacum } \\
\text { officinale }\end{array}$ & 0 & 0 & 0 & 2.5 & 0 & 0 & 0 & 2.5 & 2.5 & 2.5 & 1 & 1.291 & 40 \\
\hline & Bull thistle & $\begin{array}{l}\text { Cirsium } \\
\text { vulgare }\end{array}$ & 0 & 0 & 0 & 0 & 0 & 0 & 0 & 2.5 & 0 & 0 & 0.25 & 0.791 & 10 \\
\hline & Bare ground & & 37.5 & \begin{tabular}{|l|}
62.5 \\
\end{tabular} & 37.5 & 37.5 & 62.5 & 37.5 & 15 & 37.5 & 62.5 & 37.5 & 42.75 & 15.3 & \\
\hline & Rock & & 2.5 & 15 & 15 & 2.5 & 15 & 2.5 & 2.5 & 2.5 & 2.5 & 2.5 & 6.25 & 6.038 & \\
\hline & Litter & & 15 & 2.5 & 2.5 & 15 & 2.5 & 2.5 & 37.5 & 2.5 & 2.5 & 15 & 9.75 & 11.39 & \\
\hline & & Total Live & 60 & 37.5 & 62.5 & 50 & 32.5 & 82.5 & 67.5 & 75 & 50 & 52.5 & 57 & & \\
\hline
\end{tabular}


Table 32. Continued.

\begin{tabular}{|c|c|c|c|c|c|c|c|c|c|c|c|c|c|c|c|}
\hline & & Frame \# & 1 & 2 & 3 & 4 & 5 & 6 & 7 & 8 & 9 & 10 & & & \\
\hline $\begin{array}{c}\text { Transect } \\
\text { ID* }\end{array}$ & $\begin{array}{l}\text { Common } \\
\text { Name }\end{array}$ & Species Name & $\begin{array}{l}\text { Mid } \\
\text { point }\end{array}$ & $\begin{array}{l}\text { Mid } \\
\text { point }\end{array}$ & $\begin{array}{c}\text { Mid } \\
\text { point }\end{array}$ & $\begin{array}{c}\text { Mid } \\
\text { point }\end{array}$ & $\begin{array}{c}\text { Mid } \\
\text { point }\end{array}$ & $\begin{array}{l}\text { Mid } \\
\text { point }\end{array}$ & $\begin{array}{l}\text { Mid } \\
\text { point }\end{array}$ & $\begin{array}{l}\text { Mid } \\
\text { point }\end{array}$ & $\begin{array}{l}\text { Mid } \\
\text { point }\end{array}$ & $\begin{array}{c}\text { Mid } \\
\text { point }\end{array}$ & $\begin{array}{c}\text { Mean } \\
\text { \%cover }\end{array}$ & SD & $\begin{array}{c}\text { Frequency } \\
(\%)\end{array}$ \\
\hline \multirow[t]{12}{*}{$\begin{array}{c}\mathrm{HOC}-\mathrm{N}- \\
01\end{array}$} & Baltic rush & $\begin{array}{l}\text { Juncus } \\
\text { balticus }\end{array}$ & 37.5 & 37.5 & 15 & 37.5 & 37.5 & 15 & 37.5 & 15 & 15 & 15 & 26.25 & 11.86 & 100 \\
\hline & Red top & Agrostis alba & 15 & 15 & 37.5 & 37.5 & 15 & 15 & 37.5 & 37.5 & 85 & 37.5 & 33.25 & 21.35 & 100 \\
\hline & Horsetail & $\begin{array}{l}\text { Equisetum } \\
\text { arvense }\end{array}$ & 2.5 & 15 & 0 & 2.5 & 15 & 2.5 & 15 & 15 & 0 & 15 & 8.25 & 7.173 & 80 \\
\hline & $\begin{array}{c}\text { Unidentified } \\
\text { forb } \# 1\end{array}$ & & 2.5 & 0 & 0 & 0 & 0 & 0 & 0 & 0 & 0 & 0 & 0.25 & 0.791 & 10 \\
\hline & Red clover & $\begin{array}{l}\text { Trifolium } \\
\text { pratense }\end{array}$ & 0 & 0 & 0 & 2.5 & 37.5 & 0 & 15 & 0 & 0 & 2.5 & 5.75 & 12.08 & 40 \\
\hline & Willow & Salix spp. & 2.5 & 2.5 & 0 & 0 & 0 & 0 & 0 & 0 & 0 & 0 & 0.5 & 1.054 & 20 \\
\hline & $\begin{array}{c}\text { Unidentified } \\
\text { forb \#2 }\end{array}$ & & 0 & 0 & 2.5 & 0 & 0 & 0 & 2.5 & 2.5 & 0 & 0 & 0.75 & 1.208 & 30 \\
\hline & Ragwort & Senecio spp. & 0 & 0 & 0 & 0 & 0 & 0 & 2.5 & 0 & 0 & 0 & 0.25 & 0.791 & 10 \\
\hline & Bare ground & & 62.5 & 15 & 37.5 & 15 & 15 & 62.5 & 2.5 & 15 & 15 & 37.5 & 27.75 & 21.23 & \\
\hline & Rock & & 2.5 & 2.5 & 2.5 & 2.5 & 2.5 & 2.5 & 2.5 & 2.5 & 2.5 & 2.5 & 2.5 & 0 & \\
\hline & Litter & & 2.5 & 37.5 & 15 & 15 & 2.5 & 15 & 15 & 15 & 15 & 15 & 14.75 & 9.534 & \\
\hline & & Total Live & 60 & 70 & 55 & 80 & 105 & 32.5 & 110 & 70 & 100 & 70 & 75.25 & & \\
\hline \multirow[t]{3}{*}{$\begin{array}{c}\mathrm{HOC}-\mathrm{N}- \\
02\end{array}$} & Baltic rush & $\begin{array}{l}\text { Juncus } \\
\text { balticus }\end{array}$ & 0 & 0 & 0 & 0 & 37.5 & 0 & 2.5 & 2.5 & 0 & 15 & 5.75 & 12.08 & 40 \\
\hline & $\begin{array}{l}\text { Intermediate } \\
\text { wheatgrass }\end{array}$ & $\begin{array}{c}\text { Agropyron } \\
\text { intermedium }\end{array}$ & 15 & 2.5 & 15 & 2.5 & 2.5 & 0 & 15 & 0 & 0 & 0 & 5.25 & 6.816 & 60 \\
\hline & $\begin{array}{l}\text { Canada } \\
\text { bluegrass }\end{array}$ & $\begin{array}{c}\text { Poa } \\
\text { compressa }\end{array}$ & 0 & 0 & 0 & 0 & 2.5 & 2.5 & 0 & 0 & 2.5 & 2.5 & 1 & 1.291 & 40 \\
\hline
\end{tabular}


Table 32. Continued.

\begin{tabular}{|c|c|c|c|c|c|c|c|c|c|c|c|c|c|c|c|}
\hline & & Frame \# & 1 & 2 & 3 & 4 & 5 & 6 & 7 & 8 & 9 & 10 & & & \\
\hline \multirow[t]{14}{*}{$\begin{array}{c}\text { Transect } \\
\text { ID* }\end{array}$} & $\begin{array}{l}\text { Common } \\
\text { Name }\end{array}$ & Species Name & \begin{tabular}{|c|} 
Mid \\
point
\end{tabular} & $\begin{array}{c}\text { Mid } \\
\text { point }\end{array}$ & $\begin{array}{c}\text { Mid } \\
\text { point }\end{array}$ & \begin{tabular}{|c|} 
Mid \\
point
\end{tabular} & $\begin{array}{c}\text { Mid } \\
\text { point }\end{array}$ & $\begin{array}{l}\text { Mid } \\
\text { point }\end{array}$ & $\begin{array}{c}\text { Mid } \\
\text { point }\end{array}$ & $\begin{array}{c}\text { Mid } \\
\text { point }\end{array}$ & $\begin{array}{c}\text { Mid } \\
\text { point }\end{array}$ & $\begin{array}{c}\text { Mid } \\
\text { point }\end{array}$ & $\begin{array}{c}\text { Mean } \\
\% \text { cover }\end{array}$ & SD & $\begin{array}{c}\text { Frequency } \\
(\%)\end{array}$ \\
\hline & $\begin{array}{c}\text { Tufted } \\
\text { hairgrass }\end{array}$ & $\begin{array}{c}\text { Deschampsia } \\
\text { caespitosa }\end{array}$ & 0 & 0 & 0 & 0 & 0 & 0 & 0 & 15 & 0 & 0 & 1.5 & 4.743 & 10 \\
\hline & Red top & Agrostis alba & 0 & 0 & 0 & 0 & 0 & 15 & 0 & 37.5 & 15 & 0 & 6.75 & 12.47 & 30 \\
\hline & $\begin{array}{l}\text { Quaking } \\
\text { aspen }\end{array}$ & $\begin{array}{l}\text { Populus } \\
\text { tremuloides }\end{array}$ & 0 & 0 & 0 & 37.5 & 0 & 0 & 0 & 0 & 0 & 0 & 3.75 & 11.86 & 10 \\
\hline & Horsetail & $\begin{array}{l}\text { Equisetum } \\
\text { spp. }\end{array}$ & 0 & 0 & 0 & 0 & 15 & 0 & 0 & 0 & 0 & 0 & 1.5 & 4.743 & 10 \\
\hline & Goldenrod & $\begin{array}{l}\text { Oligoneuron } \\
\text { spp. }\end{array}$ & 0 & 0 & 0 & 2.5 & 2.5 & 0 & 0 & 0 & 0 & 2.5 & 0.75 & 1.208 & 30 \\
\hline & Red clover & $\begin{array}{l}\text { Trifolium } \\
\text { pratense }\end{array}$ & 0 & 0 & 0 & 0 & 0 & 0 & 15 & 0 & 0 & 0 & 1.5 & 4.743 & 10 \\
\hline & $\begin{array}{l}\text { Cudweed } \\
\text { sagewort }\end{array}$ & $\begin{array}{c}\text { Artemisia } \\
\text { ludoviciana }\end{array}$ & 0 & 0 & 0 & 0 & 0 & 0 & 0 & 0 & 15 & 0 & 1.5 & 4.743 & 10 \\
\hline & Yarrow & $\begin{array}{c}\text { Achillea } \\
\text { millefolium }\end{array}$ & 0 & 2.5 & 0 & 0 & 0 & 0 & 0 & 0 & 0 & 2.5 & 0.5 & 1.054 & 20 \\
\hline & $\begin{array}{c}\text { Dwarf } \\
\text { Fireweed }\end{array}$ & $\begin{array}{l}\text { Epilobium } \\
\text { latifolium }\end{array}$ & 0 & 0 & 2.5 & 0 & 0 & 0 & 0 & 0 & 0 & 0 & 0.25 & 0.791 & 10 \\
\hline & $\begin{array}{l}\text { Bare } \\
\text { ground }\end{array}$ & & 92.5 & 92.5 & 92.5 & 85 & 37.5 & 92.5 & 62.5 & 15 & 37.5 & 15 & 62.25 & 33.11 & \\
\hline & Rock & & 2.5 & 2.5 & 2.5 & 2.5 & 2.5 & 2.5 & 37.5 & 37.5 & 37.5 & 37.5 & 16.5 & 18.07 & \\
\hline & Litter & & 2.5 & 15 & 2.5 & 2.5 & 2.5 & 2.5 & 2.5 & 2.5 & 2.5 & 2.5 & 3.75 & 3.953 & \\
\hline & & Total Live & 15 & 5 & 17.5 & 42.5 & 60 & 17.5 & 32.5 & 55 & 32.5 & 22.5 & 30 & & \\
\hline
\end{tabular}


Table 32. Continued.

\begin{tabular}{|c|c|c|c|c|c|c|c|c|c|c|c|c|c|c|c|}
\hline & & Frame \# & 1 & 2 & 3 & 4 & 5 & 6 & 7 & 8 & 9 & 10 & & & \\
\hline $\begin{array}{c}\text { Transect } \\
\text { ID* }\end{array}$ & $\begin{array}{l}\text { Common } \\
\text { Name }\end{array}$ & Species Name & $\begin{array}{l}\text { Mid } \\
\text { point }\end{array}$ & $\begin{array}{c}\text { Mid } \\
\text { point }\end{array}$ & $\begin{array}{c}\text { Mid } \\
\text { point }\end{array}$ & \begin{tabular}{|l|} 
Mid \\
point
\end{tabular} & $\begin{array}{l}\text { Mid } \\
\text { point }\end{array}$ & \begin{tabular}{|c|} 
Mid \\
point
\end{tabular} & $\begin{array}{l}\text { Mid } \\
\text { point }\end{array}$ & $\begin{array}{l}\text { Mid } \\
\text { point }\end{array}$ & $\begin{array}{c}\text { Mid } \\
\text { point }\end{array}$ & $\begin{array}{c}\text { Mid } \\
\text { point }\end{array}$ & $\begin{array}{c}\text { Mean } \\
\% \text { cover }\end{array}$ & SD & $\begin{array}{c}\text { Frquency } \\
(\%)\end{array}$ \\
\hline \multirow[t]{15}{*}{$\begin{array}{c}\mathrm{HOC}-\mathrm{N}- \\
03 \\
\end{array}$} & Red top & Agrostis alba & 15 & 15 & 37.5 & 15 & 15 & 2.5 & 15 & 15 & 15 & 2.5 & 14.75 & 9.534 & 100 \\
\hline & Horsetail & $\begin{array}{l}\text { Equisetum } \\
\text { arvense }\end{array}$ & 37.5 & 37.5 & 15 & 37.5 & 37.5 & 2.5 & 15 & 0 & 2.5 & 15 & 20 & 16.03 & 90 \\
\hline & Baltic rush & $\begin{array}{l}\text { Juncus } \\
\text { balticus }\end{array}$ & 62.5 & 37.5 & 15 & 2.5 & 37.5 & 0 & 0 & 0 & 15 & 15 & 18.5 & 21.02 & 70 \\
\hline & $\begin{array}{l}\text { Nebraska } \\
\text { sedge }\end{array}$ & $\begin{array}{c}\text { Carex } \\
\text { nebrascensis }\end{array}$ & 0 & 0 & 0 & 15 & 0 & 0 & 15 & 0 & 0 & 0 & 3 & 6.325 & 20 \\
\hline & Bull thistle & $\begin{array}{l}\text { Cirsium } \\
\text { vulgare }\end{array}$ & 15 & 15 & 2.5 & 0 & 0 & 0 & 0 & 0 & 2.5 & 0 & 3.5 & 6.146 & 40 \\
\hline & Red clover & $\begin{array}{l}\text { Trifolium } \\
\text { pratense }\end{array}$ & 2.5 & 0 & 2.5 & 0 & 15 & 0 & 15 & 0 & 0 & 0 & 3.5 & 6.146 & 40 \\
\hline & $\begin{array}{c}\text { Unidentified } \\
\text { forb \#6 }\end{array}$ & & 0 & 0 & 15 & 0 & 15 & 0 & 0 & 0 & 0 & 0 & 3 & 6.325 & 20 \\
\hline & $\begin{array}{c}\text { Unidentified } \\
\text { forb \#7 }\end{array}$ & & 0 & 0 & 0 & 0 & 2.5 & 0 & 0 & 0 & 0 & 0 & 0.25 & 0.791 & 10 \\
\hline & Willow & Salix spp. & 15 & 2.5 & 2.5 & 0 & 2.5 & 0 & 0 & 0 & 15 & 0 & 3.75 & 6.038 & 50 \\
\hline & Yarrow & $\begin{array}{c}\text { Achillea } \\
\text { millefolium }\end{array}$ & 0 & 0 & 0 & 0 & 0 & 62.5 & 62.5 & 2.5 & 2.5 & 2.5 & 13.25 & 25.98 & 50 \\
\hline & $\begin{array}{c}\text { Unidentified } \\
\text { forb \#8 }\end{array}$ & & 0 & 0 & 0 & 0 & 0 & 0 & 0 & 0 & 15 & 0 & 1.5 & 4.743 & 10 \\
\hline & Bare ground & & 2.5 & 2.5 & 2.5 & 2.5 & 2.5 & 15 & 2.5 & 15 & 2.5 & 2.5 & 5 & 5.27 & \\
\hline & Rock & & 2.5 & 2.5 & 2.5 & 2.5 & 2.5 & 2.5 & 2.5 & 2.5 & 2.5 & 2.5 & 2.5 & 0 & \\
\hline & Litter & & 2.5 & 15 & 37.5 & 37.5 & 15 & 37.5 & 15 & 62.5 & 62.5 & 62.5 & 34.75 & 22.47 & \\
\hline & & Total Live & 148 & 108 & 90 & 70 & 125 & 67.5 & 123 & 17.5 & 67.5 & 35 & 85 & & \\
\hline
\end{tabular}

\footnotetext{
* HOC=High Ore Creek, P=Partial Removal, N=No Removal
} 
Table 33. Production data from High Ore Creek

\begin{tabular}{|c|c|c|c|c|c|c|c|c|c|c|c|c|c|c|}
\hline & $\begin{array}{c}\text { Life } \\
\text { Form }\end{array}$ & $\begin{array}{c}\text { Frame } \\
1\end{array}$ & $\begin{array}{c}\text { Frame } \\
2\end{array}$ & $\begin{array}{c}\text { Frame } \\
3\end{array}$ & $\begin{array}{c}\text { Frame } \\
4\end{array}$ & $\begin{array}{c}\text { Frame } \\
5\end{array}$ & $\begin{array}{c}\text { Frame } \\
6\end{array}$ & $\begin{array}{c}\text { Frame } \\
7\end{array}$ & $\begin{array}{c}\text { Frame } \\
8\end{array}$ & $\begin{array}{c}\text { Frame } \\
9\end{array}$ & $\begin{array}{c}\text { Frame } \\
10\end{array}$ & Mean & $\begin{array}{c}\text { Standard } \\
\text { Deviation }\end{array}$ & $\begin{array}{c}\text { Total } \\
\text { Production }\end{array}$ \\
\hline Transect ID* & & Wt (g) & Wt (g) & Wt (g) & Wt (g) & Wt (g) & Wt (g) & Wt (g) & Wt (g) & Wt (g) & Wt (g) & (g) & & $\mathrm{kg} / \mathrm{ha}$ \\
\hline HOC-P-01 & Grass & 0 & 1.96 & 0 & 0 & 0.44 & 6.38 & 3.9 & 0 & 0.16 & 0 & 1.28 & 2.20 & 205.44 \\
\hline & Forb & 15.38 & 9.06 & 7.93 & 12.67 & 10.35 & 8 & 16.05 & 8.46 & 6.55 & 6.74 & 10.12 & 3.44 & 1619.04 \\
\hline & Shrub & & & & & & & & & & & & & 0.00 \\
\hline & Total & 15.38 & 11.02 & 7.93 & 12.67 & 10.79 & 14.38 & 19.95 & 8.46 & 6.71 & 6.74 & 11.40 & 4.27 & 1824.48 \\
\hline & & & & & & & & & & & & & & \\
\hline HOC-P-02 & Grass & 5.38 & 0.11 & 11.57 & 3.92 & 11.74 & 0 & 2.49 & 4.58 & 1 & 4.41 & 4.52 & 4.21 & 723.20 \\
\hline & Forb & 2.21 & 10.23 & 1.66 & 3.12 & 0.23 & 8.36 & 4.11 & 3.79 & 0.26 & 0.4 & 3.44 & 3.42 & 549.92 \\
\hline & Shrub & & & & & & & & & & & & & 0.00 \\
\hline & Total & 7.59 & 10.34 & 13.23 & 7.04 & 11.97 & 8.36 & 6.6 & 8.37 & 1.26 & 4.81 & 7.96 & 3.46 & 1273.12 \\
\hline & & & & & & & & & & & & & & \\
\hline HOC-P-03 & Grass & 4.2 & 2.83 & 5.28 & 11.45 & 7.9 & 2.73 & 0.06 & 7.03 & 9.7 & 5.43 & 5.66 & 3.45 & 905.76 \\
\hline & Forb & 5.17 & 0 & 0 & 0.91 & 0 & 5.79 & 3.55 & 0.65 & 0.37 & 0.92 & 1.74 & 2.23 & 277.76 \\
\hline & Shrub & 0 & 0 & 0 & 0 & 0 & 0 & 0 & 0 & 0 & 0 & 0.00 & & \\
\hline & Horsetail & 0 & 0 & 0 & 0 & 0.75 & 0 & 1.78 & 0.69 & 0 & 0.31 & 0.35 & 0.58 & 56.48 \\
\hline & Total & 9.37 & 2.83 & 5.28 & 12.36 & 8.65 & 8.52 & 5.39 & 8.37 & 10.07 & 6.66 & 7.75 & 2.75 & 1240.00 \\
\hline & & & & & & & & & & & & & \\
\hline
\end{tabular}


Table 33. Continued.

\begin{tabular}{|c|c|c|c|c|c|c|c|c|c|c|c|c|c|c|}
\hline & $\begin{array}{c}\text { Life } \\
\text { Form }\end{array}$ & $\begin{array}{c}\text { Frame } \\
1\end{array}$ & $\begin{array}{c}\text { Frame } \\
2\end{array}$ & $\begin{array}{c}\text { Frame } \\
3\end{array}$ & $\begin{array}{c}\text { Frame } \\
4\end{array}$ & $\begin{array}{c}\text { Frame } \\
5\end{array}$ & $\begin{array}{c}\text { Frame } \\
6\end{array}$ & $\begin{array}{c}\text { Frame } \\
7\end{array}$ & $\begin{array}{c}\text { Frame } \\
8\end{array}$ & $\begin{array}{c}\text { Frame } \\
9\end{array}$ & $\begin{array}{c}\text { Frame } \\
10\end{array}$ & Mean & $\begin{array}{c}\text { Standard } \\
\text { Deviation }\end{array}$ & $\begin{array}{c}\text { Total } \\
\text { Production }\end{array}$ \\
\hline Transect ID* & & Wt (g) & Wt (g) & Wt (g) & Wt (g) & Wt (g) & Wt (g) & Wt (g) & Wt (g) & Wt (g) & Wt (g) & $(\mathrm{g})$ & & $\mathrm{kg} / \mathrm{ha}$ \\
\hline HOC-N-02 & Grass & 0.24 & 0.21 & 0.2 & 0.9 & 9 & 1 & 1.04 & 3.5 & 3.59 & 2.02 & 2.17 & 2.71 & 347.20 \\
\hline & Forb & 0 & 0.14 & 0.1 & 0.17 & 0 & 0 & 0.31 & 0 & 0.82 & 0 & 0.15 & 0.26 & 24.64 \\
\hline & Shrub & 0 & 0 & 0 & 0 & 0 & 0 & 0 & 0 & 0 & 0 & 0.00 & 0.00 & 0.00 \\
\hline & Horsetail & 0 & 0 & 0 & 0 & 1.25 & 0 & 0 & 0 & 0 & 0 & 0.13 & 0.40 & 20.00 \\
\hline & Tree & 4.73 & 0 & 0 & 0 & 0 & 0 & 0 & 0 & 0 & 0 & 0.47 & 1.50 & 75.68 \\
\hline & Total & 4.97 & 0.35 & 0.3 & 1.07 & 10.25 & 1 & 1.35 & 3.5 & 4.41 & 2.02 & 2.92 & 3.06 & 467.52 \\
\hline & & & & & & & & & & & & & & \\
\hline HOC-N-03 & Grass & 19.07 & 10.41 & 10.44 & 2.81 & 10.86 & 0 & 2.48 & 1.28 & 4.3 & 3.79 & 6.54 & 5.96 & 1047.04 \\
\hline & Forb & 0 & 1.54 & 0.41 & 0.82 & 0.51 & 3.77 & 5.23 & 0.11 & 1.13 & 0.25 & 1.38 & 1.75 & 220.32 \\
\hline & Shrub & 0 & 0 & 0 & 0 & 0 & 0 & 0 & 0 & 0 & 0 & 0.00 & 0.00 & 0.00 \\
\hline & Horsetail & 4.74 & 1.7 & 1.16 & 4.88 & 3.48 & 0.1 & 1.56 & 0 & 0 & 2.51 & 2.01 & 1.85 & 322.08 \\
\hline & Total & 23.81 & 13.65 & 12.01 & 8.51 & 14.85 & 3.87 & 9.27 & 1.39 & 5.43 & 6.55 & 9.93 & 6.49 & 1589.44 \\
\hline
\end{tabular}

* HOC= High Ore Creek, $\mathrm{P}=$ Partial Removal, $\mathrm{N}=$ No Removal 
APPENDIX B:

SPECIES LISTS 
Table 34. Species list from the Gregory Mine.

Life Form

Graminoids:

Agropyron dasystachyum

Agropyron trachycaulum

Agrostis alba

Carex garberi

Carex nebrascensis

Carex spp.

Danthonia spp.

Deschampsia caespitosa

Equisetum arvense

Festuca idahoensis

Festuca scabrella

Glyceria striata

Hordeum jubatum

Juncus balticus

Juncus bufonius

Koeleria cristata

Lolium multiflorum

Lolium perenne

Panicum virgatum

Phleum pratense

Poa compressa

Poa Pratensis

Typha spp.

Forbs and Legumes:
Common Name

Thickspike Wheatgrass

Slender Wheatgrass

Red Top

Elk Sedge

Nebraska Sedge

Sedge

Oatgrass

Tufted Hairgrass

Field Horsetail

Idaho Fescue

Rough Fescue

Fowl Mannegrass

Foxtail Barley

Baltic Rush

Toad Rush

Prairie Junegrass

Italian Ryegrass

Ryegrass

Switch Grass

Timothy

Canada Bluegrass

Kentucky Bluegrass

Cattail

Western Yarrow

Pussytoes

Cudweed Sagewort

Milkvetch

Field Mustard

Whitetop

Bull thistle

Dwarf Fireweed

Smooth Scouringrush

Strawberry

Curlycup Gumweed

Hounds Tongue

Rocky Mountain Iris

Dalmatian Toadflax

Purple Aster 
Table 34. Continued.

Life Form

Forbs and Legumes:
Scientific Name

Common Name

Tarweed

Alfalfa

Wild Mint

Owl Clover

Broadleaf Plantain

Sulfur Cinquefoil

Tall Buttercup

Woods Rose

Curly Dock

Goldenrod

Chickweed

Dandelion

Red Clover

White Clover

Common Mullein

Unknown Forb \#1

Unknown Forb \#2

Unknown Forb \#3

Unknown Forb \#4

Cottonwood

Quaking Aspen

Prickly Rose

Willow 
Table 35. Species list from the Comet Mine.

\section{Life Form}

Graminoids:

Forbs and Legumes:
Common Name

Columbia Needlegrass
Western Wheatgrass
Bluebunch Wheatgrass
Slender Wheatgrass
Red Top
Sedge
Brookgrass
Orchardgrass
Tufted Hairgrass
Idaho Fescue
Foxtail Barley
Baltic Rush
Timothy
Kentucky Bluegrass
Sandberg Bluegrass
Cattail

Western Yarrow

Cudweed Sagewort

Dwarf Fireweed

Field Horsetail

Leafy Spurge

Blue Flax

Wild Lupine

Purple Aster

Alfalfa

Yellow Sweetclover

Wild Mint

Monkeyflower

Watercress

Sulfur Cinquefoil

Curly Dock

Goldenrod

Red Clover

White Clover 
Table 35. Continued.

Life Form

Trees and Shrubs:
Scientific Name

Amelanchier spp.

Artemisia tridentate

Cornus spp.

Ericameria nauseosa

Salix spp.
Common Name

Serviceberry

Big Sage

Dogwood

Rubber Rabbitbrush

Willow 
Table 36. Species list from High Ore Creek.

Life Form

Graminoids:

Forbs and Legumes:
Common Name

Columbia Needlegrass
Thickspike Wheatgrass
Intermediate Wheatgrass
Western Wheatgrass
Bluebunch Wheatgrass
Slender Wheatgrass
Red Top
Japanese Brome
Mountain Brome
Cheatgrass
Nebraska Sedge
Sedge
Brookgrass
Tufted hairgrass
Idaho Fescue
Baltic Rush
Prairie Junegrass
Canada Bluegrass
Sandberg Bluegrass

Western Yarrow

Cudweed Sagewort

Mustard

Canada Thistle

Leather Flower

Dwarf Fireweed

Field Horsetail

Strawberry

Pepperweed

Blue Flax

Wild Lupine

Black Medic

Yellow Sweetclover

Wild Mint

Monkeyflower

Butterweed

Sulfur Cinquefoil

Ragwort

Goldenrod 
Table 36. Continued.

Life Form

Forbs and Legumes:

Sonchus arvensis
Taraxacum officinale
Thelypodiopsis
Tragopogon porrifolius
Trifolium pratense
Trifolium repens
Verbascum thapsus

Trees and Shrubs:
Common Name

Field Sowthistle

Dandelion

Tumble Mustard

Salsify

Red Clover

White Clover

Common Mullein

Musk Thistle

Alder
Big Sage
Rubber Rabbitbrush
Prickly Rose
Wild Raspberry
Willow


APPENDIX C:

SOIL CHEMISTRY DATA 
Table 37. Soil nutrients data from the Gregory Mine.

\begin{tabular}{|c|c|c|c|c|c|c|c|}
\hline Transect ID & $\begin{array}{c}\text { Sample } \\
\#\end{array}$ & Pit \# & $\begin{array}{l}\text { Depth in } \\
\text { Profile } \\
\text { (cm) }\end{array}$ & $\begin{array}{c}\mathrm{K} \\
(\mathrm{mg} / \mathrm{kg})\end{array}$ & $\begin{array}{c}\mathrm{NO}_{3}-\mathrm{N} \\
(\mathrm{mg} / \mathrm{kg})\end{array}$ & $\begin{array}{l}\text { Bray P } \\
(\mathrm{mg} / \mathrm{kg})\end{array}$ & $\%$ OM \\
\hline \multirow[t]{2}{*}{ GR-SB-G-01 } & 1 & $1,2,3$ & $0-20$ & 234 & 0.3 & 30.4 & 3.9 \\
\hline & 2 & $1,2,3$ & $20-30$ & 96 & 0.2 & 18.5 & 0.99 \\
\hline \multirow[t]{2}{*}{ GR-SB-G-02 } & 3 & $1,2,3$ & $0-20$ & 366 & 0.5 & 37.7 & 7.4 \\
\hline & 4 & $1,2,3$ & $20-30$ & 156 & 0.4 & 17.3 & 0.7 \\
\hline GR-SB-G-03 & 5 & $1,2,3$ & $0-30$ & 238 & 0.3 & 19.6 & 9.63 \\
\hline \multirow[t]{2}{*}{ GR-SB-M-01 } & 6 & $1,2,3$ & $0-15$ & 284 & 0.4 & 39.5 & 5.57 \\
\hline & 7 & $1,2,3$ & $15-30$ & 214 & 0.4 & 13.7 & 0.76 \\
\hline \multirow[t]{2}{*}{ GR-SB-M-02 } & 8 & $1,2,3$ & $0-10$ & 276 & 0.5 & 38.8 & 4.74 \\
\hline & 10 & $1,2,3$ & $10-30$ & 308 & 0.5 & 30.4 & 5.16 \\
\hline \multirow[t]{3}{*}{ GR-SB-M-03 } & 11 & $1,2,3$ & $0-18$ & 162 & 0.2 & 30 & 0.72 \\
\hline & 12 & $1,2,3$ & $18-30$ & 128 & 0.3 & 19.6 & 1.31 \\
\hline & 13 & 1 & $0-8$ & 218 & 0.4 & 34 & 4.84 \\
\hline \multirow[t]{5}{*}{ GR-SB-P-01 } & 14 & $1,2,3$ & $0-5$ & 188 & 0.4 & 24.8 & 3.16 \\
\hline & 15 & 1,3 & $5-25$ & 70 & 0.3 & 33.4 & 2.97 \\
\hline & 16 & 1 & $25-30$ & 66 & 0.2 & 26.8 & 0.38 \\
\hline & 17 & 2,3 & $0-15$ & 90 & 0.1 & 68.1 & 2.64 \\
\hline & 18 & 2 & $15-30$ & 120 & 0.3 & 42.4 & 5.73 \\
\hline \multirow[t]{2}{*}{ GR-SB-P-02 } & 19 & $1,2,3$ & $0-13$ & 76 & 0.2 & 49.2 & 3.61 \\
\hline & 20 & $1,2,3$ & $13-30$ & 104 & 0.3 & 83.3 & 3.42 \\
\hline \multirow[t]{4}{*}{ GR-SB-P-03 } & 21 & $1,2,3$ & $0-5$ & 246 & 0.3 & 60.7 & 8.15 \\
\hline & 22 & $1,2,3$ & $5-30$ & 158 & 0.5 & 85.5 & 4.25 \\
\hline & 23 & $1,2,3$ & $0-13$ & 204 & 0.4 & 23.7 & 10.6 \\
\hline & 24 & $1,2,3$ & $13-30$ & 148 & 0.1 & 1.7 & 3.61 \\
\hline \multirow[t]{2}{*}{ GR-OV-G-01 } & 27 & $1,2,3$ & $0-20$ & 430 & 5.8 & 37.4 & 6.72 \\
\hline & 28 & $1,2,3$ & $20-61$ & & & & \\
\hline GR-OV-G-02 & 29 & $1,2,3$ & $0-20$ & 248 & 0.2 & 40.1 & 6.61 \\
\hline
\end{tabular}


Table 37. Continued.

\begin{tabular}{|c|c|c|c|c|c|c|c|}
\hline & 30 & $1,2,3$ & $20-61$ & & & & \\
\hline \multirow[t]{4}{*}{ GR-OV-G-03 } & 31 & $1,2,3$ & $0-25$ & 248 & 1.8 & 46.7 & 5.6 \\
\hline & 32 & 1 & $25-61$ & & & & \\
\hline & 33 & 2 & $15-61$ & & & & \\
\hline & 34 & 3 & $25-61$ & & & & \\
\hline \multirow[t]{3}{*}{ GR-OV-M-01 } & 35 & $1,2,3$ & $0-30$ & 222 & 9.1 & 29.5 & 6.08 \\
\hline & 36 & 3 & $30-61$ & & & & \\
\hline & 37 & 1,2 & $30-61$ & & & & \\
\hline \multirow[t]{3}{*}{ GR-OV-M-02 } & 38 & $1,2,3$ & $0-13$ & 252 & 2.8 & 17.3 & 5.06 \\
\hline & 40 & $1,2,3$ & $13-46$ & & & & \\
\hline & 41 & 1,3 & $46-61$ & & & & \\
\hline \multirow[t]{3}{*}{ GR-OV-M-03 } & 42 & $1,2,3$ & $0-51$ & 154 & 0.3 & 69.1 & 3.6 \\
\hline & 44 & 1,2 & $51-61$ & & & & \\
\hline & 45 & 3 & $41-61$ & & & & \\
\hline \multirow[t]{2}{*}{ GR-OV-P-01 } & 46 & $1,2,3$ & $0-15$ & 36 & $<.1$ & 42.4 & 4.52 \\
\hline & 47 & $1,2,3$ & $15-61$ & & & & \\
\hline \multirow[t]{2}{*}{ GR-OV-P-02 } & 48 & 1 & $0-18$ & 46 & 0.3 & 51.2 & 3.1 \\
\hline & 49 & 1 & $18-61$ & & & & \\
\hline \multirow[t]{3}{*}{ GR-OV-P-03 } & 50 & $1,2,3$ & $0-15$ & 296 & 4.4 & 72.4 & 5.31 \\
\hline & 51 & $1,2,3$ & $15-61$ & & & & \\
\hline & 52 & 3 & $46-61$ & & & & \\
\hline $\begin{array}{c}\text { sample \#8 } \\
\text { dup. }\end{array}$ & 9 & $1,2,3$ & $0-15$ & 232 & 0.2 & 30.9 & 5.64 \\
\hline $\begin{array}{c}\text { Sample \#38 } \\
\text { dup. }\end{array}$ & 39 & $1,2,3$ & $0-13$ & 242 & 3.5 & 18.5 & 5.32 \\
\hline $\begin{array}{c}\text { Sample \#42 } \\
\text { dup. }\end{array}$ & 43 & $1,2,3$ & $0-51$ & 178 & 0.4 & 81.4 & 3.99 \\
\hline
\end{tabular}


Table 38. Soluble metals and As data from topsoils collected at the Gregory Mine.

\begin{tabular}{|c|c|c|c|c|c|c|c|c|c|c|}
\hline Transect ID & $\begin{array}{c}\text { Sample } \\
\#\end{array}$ & Pit \# & $\begin{array}{c}\text { Depth in } \\
\text { Profile }(\mathrm{cm})\end{array}$ & $\mathrm{pH}$ & $\begin{array}{c}\text { EC } \\
(\mu S)\end{array}$ & $\begin{array}{c}\text { Soluble } \\
\text { Cu } \\
(\mathrm{mg} / \mathrm{L})\end{array}$ & $\begin{array}{c}\text { Soluble } \\
\text { Zn } \\
(\mathrm{mg} / \mathrm{L})\end{array}$ & $\begin{array}{c}\text { Soluble } \\
\text { Cd } \\
(\mathrm{mg} / \mathrm{L})\end{array}$ & $\begin{array}{c}\text { Soluble } \\
\text { As } \\
(\mathrm{mg} / \mathrm{L})\end{array}$ & $\begin{array}{c}\text { Soluble } \\
\mathrm{Pb} \\
(\mathrm{mg} / \mathrm{L})\end{array}$ \\
\hline \multirow{2}{*}{ GR-SB-G-01 } & 1 & $1,2,3$ & $0-20$ & 5.07 & 1450 & 0.02 & 5.9 & 0.01 & $<.05$ & $<.1$ \\
\hline & 2 & $1,2,3$ & $20-30$ & 6.29 & 870 & 0.13 & 11.5 & 0.08 & $<.05$ & $<.1$ \\
\hline \multirow[t]{2}{*}{ GR-SB-G-02 } & 3 & $1,2,3$ & $0-20$ & 6.14 & 2980 & 0.02 & 0.3 & $<.01$ & 0.09 & $<.1$ \\
\hline & 4 & $1,2,3$ & $20-30$ & 6.55 & 1730 & 0.02 & 1.4 & $<.01$ & 0.09 & $<.1$ \\
\hline GR-SB-G-03 & 5 & $1,2,3$ & $0-30$ & 5.83 & 2180 & 0.02 & 7.9 & 0.01 & 0.05 & $<.1$ \\
\hline \multirow[t]{2}{*}{ GR-SB-M-01 } & 6 & $1,2,3$ & $0-15$ & 5.39 & 2320 & 0.03 & 6.1 & $<.01$ & 0.07 & $<.1$ \\
\hline & 7 & $1,2,3$ & $15-30$ & 7.05 & 1130 & 0.03 & 0.3 & $<.01$ & $<.05$ & $<.1$ \\
\hline \multirow{2}{*}{ GR-SB-M-02 } & 8 & $1,2,3$ & $0-10$ & 6.6 & 2900 & 0.04 & 0.5 & $<.01$ & 0.19 & $<.1$ \\
\hline & 10 & $1,2,3$ & $10-30$ & 6.64 & 2950 & 0.06 & $<.1$ & $<.01$ & 0.21 & $<.1$ \\
\hline \multirow[t]{3}{*}{ GR-SB-M-03 } & 11 & $1,2,3$ & $0-18$ & 6.07 & 1820 & 0.15 & 18.6 & 0.06 & 0.49 & $<.1$ \\
\hline & 12 & $1,2,3$ & $18-30$ & 6.85 & 2560 & 0.02 & 2.1 & $<.01$ & 1.01 & $<.1$ \\
\hline & 13 & 1 & $0-8$ & 6.23 & 1810 & 0.06 & 10.7 & 0.05 & 0.63 & $<.1$ \\
\hline \multirow[t]{5}{*}{ GR-SB-P-01 } & 14 & $1,2,3$ & $0-5$ & 3.05 & 2800 & 4.00 & 64.1 & 0.51 & 0.2 & 0.3 \\
\hline & 15 & 1,3 & $5-25$ & 2.97 & 2880 & 1.01 & 10.5 & 0.08 & $<.05$ & $<.1$ \\
\hline & 16 & 1 & $25-30$ & 3.19 & 790 & 0.97 & 5.8 & 0.07 & $<.05$ & $<.1$ \\
\hline & 17 & 2,3 & $0-15$ & 3.78 & 830 & 0.2 & 50.9 & 0.37 & 0.11 & $<.1$ \\
\hline & 18 & 2 & $15-30$ & 3.26 & 1210 & 0.92 & 23.1 & 0.11 & 0.13 & $<.1$ \\
\hline \multirow[t]{2}{*}{ GR-SB-P-02 } & 19 & $1,2,3$ & $0-13$ & 3.96 & 960 & 3.51 & 496.6 & 3.35 & 3.45 & 3.4 \\
\hline & 20 & $1,2,3$ & $13-30$ & 5.64 & 4480 & 0.05 & 95.5 & 0.02 & 9.99 & 0.6 \\
\hline \multirow[t]{4}{*}{ GR-SB-P-03 } & 21 & $1,2,3$ & $0-5$ & 3.84 & 3310 & 2.55 & 1001.3 & 7.39 & 3.42 & 7.6 \\
\hline & 22 & $1,2,3$ & $5-30$ & 4.39 & 6720 & 0.09 & 603 & 0.15 & 12.26 & 4.8 \\
\hline & 23 & $1,2,3$ & $0-13$ & 5.16 & 4120 & 0.03 & 68.2 & 0.06 & 5.2 & 0.9 \\
\hline & 24 & $1,2,3$ & $13-30$ & 5.67 & 3370 & 0.04 & 5.6 & 0.03 & 2.48 & 0.3 \\
\hline \multirow[t]{2}{*}{ GR-OV-G-01 } & 21 & $1,2,3$ & $0-20$ & 4.94 & 2931 & 0.03 & 4.61 & 0.01 & 0.05 & $<.1$ \\
\hline & 22 & $1,2,3$ & $20-61$ & 2.87 & 1904 & 2.94 & 47.16 & 0.35 & 0.12 & 0.1 \\
\hline GR-OV-G-02 & 23 & $1,2,3$ & $0-20$ & 5.19 & 1869 & 0.11 & 5.89 & 0.02 & 0.29 & $<.1$ \\
\hline
\end{tabular}


Table 38. Continued.

\begin{tabular}{|c|c|c|c|c|c|c|c|c|c|c|}
\hline Transect ID & $\begin{array}{c}\text { Sample } \\
\#\end{array}$ & Pit \# & $\begin{array}{c}\text { Depth in } \\
\text { Profile }(\mathrm{cm})\end{array}$ & $\mathrm{pH}$ & $E C(\mu S)$ & $\begin{array}{c}\text { SolubleCu } \\
(\mathrm{mg} / \mathrm{L})\end{array}$ & $\begin{array}{c}\text { SolubleZn } \\
(\mathrm{mg} / \mathrm{L})\end{array}$ & $\begin{array}{c}\text { SolubleCd } \\
(\mathrm{mg} / \mathrm{L})\end{array}$ & $\begin{array}{c}\text { SolubleAs } \\
(\mathrm{mg} / \mathrm{L})\end{array}$ & $\begin{array}{c}\text { SolublePb } \\
(\mathrm{mg} / \mathrm{L})\end{array}$ \\
\hline & 24 & $1,2,3$ & $20-61$ & 5.14 & 1174 & 0.11 & 5.04 & 0.09 & 0.41 & $<.1$ \\
\hline \multirow{4}{*}{ GR-OV-G-03 } & 25 & $1,2,3$ & $0-25$ & 5.55 & 233.3 & 0.07 & 0.63 & $<.01$ & 0.25 & $<.1$ \\
\hline & 26 & 1 & $25-61$ & 5.32 & 295.6 & 0.1 & 2.85 & 0.02 & $<.05$ & $<.1$ \\
\hline & 27 & 2 & $15-61$ & 5.18 & 568 & 0.03 & 3.56 & $<.01$ & $<.05$ & $<.1$ \\
\hline & 28 & 3 & $25-61$ & 4.95 & 433.9 & 0.06 & 2.81 & 0.01 & $<.05$ & $<.1$ \\
\hline \multirow[t]{3}{*}{ GR-OV-M-01 } & 29 & $1,2,3$ & $0-30$ & 5.21 & 596 & 0.03 & 0.77 & $<.01$ & $<.05$ & $<.1$ \\
\hline & 30 & 3 & $30-61$ & 2.24 & $7.48 \mathrm{mS}$ & 4.78 & 77.49 & 0.65 & 2.72 & 2.6 \\
\hline & 31 & 1,2 & $30-61$ & 2.88 & 3492 & 1.62 & 43.96 & 0.38 & 0.14 & 1.2 \\
\hline \multirow[t]{3}{*}{ GR-OV-M-02 } & 32 & $1,2,3$ & $0-13$ & 5.11 & 427 & 0.04 & 0.62 & $<.01$ & $<.05$ & $<.1$ \\
\hline & 34 & $1,2,3$ & $13-46$ & 6.24 & 674 & 0.07 & 10.97 & 0.06 & $<.05$ & $<.1$ \\
\hline & 35 & 1,3 & $46-61$ & 5.69 & 869 & 0.06 & 9.13 & 0.04 & $<.05$ & $<.1$ \\
\hline \multirow[t]{3}{*}{ GR-OV-M-03 } & 36 & $1,2,3$ & $0-51$ & 4.12 & 476 & 0.06 & 3.42 & 0.03 & 0.16 & $<.1$ \\
\hline & 38 & 1,2 & $51-61$ & 4.05 & 1071 & 0.29 & 15.38 & 0.09 & 0.15 & 0.2 \\
\hline & 39 & 3 & $41-61$ & 3.38 & 508 & 1.09 & 8.16 & 0.09 & 0.2 & $<.1$ \\
\hline \multirow[t]{2}{*}{ GR-OV-P-01 } & 40 & $1,2,3$ & $0-15$ & 3.35 & 3711 & 0.55 & 38.2 & 0.26 & 0.22 & 0.3 \\
\hline & 41 & $1,2,3$ & $15-61$ & 2.08 & 12.95 & 20.81 & 136.63 & 1.52 & 10.4 & 1.5 \\
\hline \multirow[t]{2}{*}{ GR-OV-P-02 } & 42 & 1 & $0-18$ & 3.09 & 1493 & 1.14 & 18.78 & 0.2 & 0.21 & 0.3 \\
\hline & 43 & 1 & $18-61$ & 2.69 & 4254 & 1.81 & 67.53 & 0.54 & 0.26 & 2.1 \\
\hline \multirow[t]{3}{*}{ GR-OV-P-03 } & 44 & $1,2,3$ & $0-15$ & 4.49 & 1419 & 0.04 & 5.45 & 0.04 & 0.25 & $<.1$ \\
\hline & 45 & $1,2,3$ & $15-61$ & 3.23 & 1235 & 1.22 & 17.9 & 0.15 & 0.2 & 0.1 \\
\hline & 46 & 3 & $46-61$ & 3.01 & 2029 & 2.13 & 37.44 & 0.42 & 0.32 & 0.2 \\
\hline Sample \#8 dup. & 9 & & $0-15$ & 6.31 & 3240 & 0.15 & 0.4 & $<.01$ & 0.15 & $<.1$ \\
\hline Sample \#32 dup. & 33 & $1,2,3$ & $0-13$ & 6.91 & 250.7 & 0.05 & 0.36 & $<.01$ & $<.05$ & $<.1$ \\
\hline Sample \#36 dup. & 37 & $1,2,3$ & $0-51$ & 4.63 & 505 & 0.04 & 2.22 & 0.02 & 0.22 & $<.1$ \\
\hline X-cont. blank & 25 & & & 7.22 & 87.5 & 0.02 & 0.1 & $<.01$ & $<.05$ & $<.1$ \\
\hline pure sand $\mathrm{SiO}_{2}$ & 26 & & & 7.46 & 74.6 & & & & & \\
\hline
\end{tabular}


Table 39. Total metals and As data from topsoil samples collected at the Gregory Mine.

\begin{tabular}{|c|c|c|c|c|c|c|c|c|}
\hline Transect ID & $\begin{array}{c}\text { Sample } \\
\#\end{array}$ & Pit \# & $\begin{array}{c}\text { Depth in } \\
\text { Profile }(\mathrm{cm})\end{array}$ & $\mathrm{pH}$ & $\begin{array}{l}\text { Total Zn } \\
(\mathrm{mg} / \mathrm{kg})\end{array}$ & $\begin{array}{l}\text { Total Cu } \\
(\mathrm{mg} / \mathrm{kg})\end{array}$ & $\begin{array}{l}\text { Total As } \\
(\mathrm{mg} / \mathrm{kg})\end{array}$ & $\begin{array}{l}\text { Total Pb } \\
(\mathrm{mg} / \mathrm{kg})\end{array}$ \\
\hline \multirow[t]{2}{*}{ GR-SB-G-01 } & 1 & $1,2,3$ & $0-20$ & 5.07 & 382.6 & $<$ LOD & 44.9 & 156.7 \\
\hline & 2 & $1,2,3$ & $20-30$ & 6.29 & 516.4 & $<\mathrm{LOD}$ & 388 & 489.2 \\
\hline \multirow[t]{2}{*}{ GR-SB-G-02 } & 3 & $1,2,3$ & $0-20$ & 6.14 & 215 & $<$ LOD & 100 & 82.3 \\
\hline & 4 & $1,2,3$ & $20-30$ & 6.55 & 434.4 & $<$ LOD & 134.8 & 55.4 \\
\hline GR-SB-G-03 & 5 & $1,2,3$ & $0-30$ & 5.83 & 1069.6 & $<\mathrm{LOD}$ & 113.7 & 227.6 \\
\hline \multirow[t]{2}{*}{ GR-SB-M-01 } & 6 & $1,2,3$ & $0-15$ & 5.39 & 281.8 & $<\mathrm{LOD}$ & 96.5 & 132.4 \\
\hline & 7 & $1,2,3$ & $15-30$ & 7.05 & 367.2 & $<$ LOD & 56.7 & 58.7 \\
\hline \multirow[t]{2}{*}{ GR-SB-M-02 } & 8 & $1,2,3$ & $0-10$ & 6.6 & 221.6 & $<\mathrm{LOD}$ & 145.7 & 154.9 \\
\hline & 10 & $1,2,3$ & $10-30$ & 6.64 & 158.2 & $<\mathrm{LOD}$ & 247.4 & 154.5 \\
\hline \multirow{3}{*}{ GR-SB-M-03 } & 11 & $1,2,3$ & $0-18$ & 6.07 & 577.6 & $<\mathrm{LOD}$ & 2468.8 & 1249.6 \\
\hline & 12 & $1,2,3$ & $18-30$ & 6.85 & 758.4 & $<$ LOD & 589.2 & 339 \\
\hline & 13 & 1 & $0-8$ & 6.23 & 866.4 & $<$ LOD & 2329.6 & 1720 \\
\hline \multirow[t]{5}{*}{ GR-SB-P-01 } & 14 & $1,2,3$ & $0-5$ & 3.05 & 228.8 & $<$ LOD & 323.8 & 298.6 \\
\hline & 15 & 1,3 & $5-25$ & 2.97 & 170.4 & $<\mathrm{LOD}$ & 217 & 128.2 \\
\hline & 16 & 1 & $25-30$ & 3.19 & 136.9 & $<$ LOD & 351.2 & 83.1 \\
\hline & 17 & 2,3 & $0-15$ & 3.78 & 513.6 & $<\mathrm{LOD}$ & 100 & 120.3 \\
\hline & 18 & 2 & $15-30$ & 3.26 & 1640 & 301.4 & 2668.8 & 7027.2 \\
\hline \multirow[t]{2}{*}{ GR-SB-P-02 } & 19 & $1,2,3$ & $0-13$ & 3.96 & 283 & $<$ LOD & 843.2 & 785.2 \\
\hline & 20 & $1,2,3$ & $13-30$ & 5.64 & 7539.2 & 455.2 & 2529.6 & 4278.4 \\
\hline \multirow[t]{4}{*}{ GR-SB-P-03 } & 21 & $1,2,3$ & $0-5$ & 3.84 & 1939.2 & $<\mathrm{LOD}$ & 1160 & 2400 \\
\hline & 22 & $1,2,3$ & $5-30$ & 4.39 & 4908.8 & $<$ LOD & 1640 & 3449.6 \\
\hline & 23 & $1,2,3$ & $0-13$ & 5.16 & 1269.6 & 328.8 & 1809.6 & 2880 \\
\hline & 24 & $1,2,3$ & $13-30$ & 5.67 & 825.6 & 438 & 2419.2 & 4297.6 \\
\hline \multirow[t]{2}{*}{ GR-OV-G-01 } & 27 & $1,2,3$ & $0-20$ & 4.94 & 27.1 & 271 & 46 & 113 \\
\hline & 28 & $1,2,3$ & $20-61$ & 2.87 & & & & \\
\hline \multirow[t]{2}{*}{ GR-OV-G-02 } & 29 & $1,2,3$ & $0-20$ & 5.19 & 107 & 739 & 214 & 279 \\
\hline & 30 & $1,2,3$ & $20-61$ & 5.14 & & & & \\
\hline
\end{tabular}


Table 39. Continued.

\begin{tabular}{|c|c|c|c|c|c|c|c|c|}
\hline Transect ID & $\begin{array}{c}\text { Sample } \\
\#\end{array}$ & Pit \# & $\begin{array}{c}\text { Depth in } \\
\text { Profile }(\mathrm{cm})\end{array}$ & $\mathrm{pH}$ & $\begin{array}{l}\text { Total Zn } \\
(\mathrm{mg} / \mathrm{kg})\end{array}$ & $\begin{array}{c}\text { Total Cu } \\
(\mathrm{mg} / \mathrm{kg})\end{array}$ & $\begin{array}{l}\text { Total As } \\
(\mathrm{mg} / \mathrm{kg})\end{array}$ & $\begin{array}{c}\text { Total Pb } \\
(\mathrm{mg} / \mathrm{kg})\end{array}$ \\
\hline \multirow[t]{4}{*}{ GR-OV-G-03 } & 31 & $1,2,3$ & $0-25$ & 5.55 & 105 & 560 & 515 & 696 \\
\hline & 32 & 1 & $25-61$ & 5.32 & & & & \\
\hline & 33 & 2 & $15-61$ & 5.18 & & & & \\
\hline & 34 & 3 & $25-61$ & 4.95 & & & & \\
\hline \multirow[t]{3}{*}{ GR-OV-M-01 } & 35 & $1,2,3$ & $0-30$ & 5.21 & 38.3 & 270 & 94 & 264 \\
\hline & 36 & 3 & $30-61$ & 2.24 & & & & \\
\hline & 37 & 1,2 & $30-61$ & 2.88 & & & & \\
\hline \multirow[t]{3}{*}{ GR-OV-M-02 } & 38 & $1,2,3$ & $0-13$ & 5.11 & 27.3 & 249 & 43 & 141 \\
\hline & 40 & $1,2,3$ & $13-46$ & 6.24 & & & & \\
\hline & 41 & 1,3 & $46-61$ & 5.69 & & & & \\
\hline \multirow[t]{3}{*}{ GR-OV-M-03 } & 42 & $1,2,3$ & $0-51$ & 4.12 & 227 & 441 & 2678 & 1383 \\
\hline & 44 & 1,2 & $51-61$ & 4.05 & & & & \\
\hline & 45 & 3 & $41-61$ & 3.38 & & & & \\
\hline \multirow[t]{2}{*}{ GR-OV-P-01 } & 46 & $1,2,3$ & $0-15$ & 3.35 & 103 & 226 & 669 & 1259 \\
\hline & 47 & $1,2,3$ & $15-61$ & 2.08 & & & & \\
\hline \multirow[t]{2}{*}{ GR-OV-P-02 } & 48 & 1 & $0-18$ & 3.09 & 160 & 318 & 785 & 2225 \\
\hline & 49 & 1 & $18-61$ & 2.69 & & & & \\
\hline \multirow[t]{3}{*}{ GR-OV-P-03 } & 50 & $1,2,3$ & $0-15$ & 4.49 & 83.4 & 315 & 819 & 225 \\
\hline & 51 & $1,2,3$ & $15-61$ & 3.23 & & & & \\
\hline & 52 & 3 & $46-61$ & 3.01 & & & & \\
\hline $\begin{array}{l}\text { Sample \#8 } \\
\text { dup. }\end{array}$ & 9 & & $0-15$ & 6.31 & 197.4 & $<$ LOD & 115 & 107.1 \\
\hline $\begin{array}{c}\text { Sample \#38 } \\
\text { dup. }\end{array}$ & 39 & $1,2,3$ & $0-13$ & 6.91 & 22.4 & 223 & 34 & 146 \\
\hline $\begin{array}{c}\text { Sample \#42 } \\
\text { dup. }\end{array}$ & 43 & $1,2,3$ & $0-51$ & 4.63 & 184 & 419 & 2218 & 1121 \\
\hline
\end{tabular}


Table 40. Soil nutrients data from topsoil samples collected at the Comet Mine.

\begin{tabular}{|c|c|c|c|c|c|c|c|}
\hline Transect ID & $\begin{array}{c}\text { Sample } \\
\#\end{array}$ & Pit \# & $\begin{array}{l}\text { Depth in } \\
\text { Profile } \\
\text { (cm) }\end{array}$ & $\begin{array}{c}\mathrm{K} \\
(\mathrm{mg} / \mathrm{kg})\end{array}$ & $\begin{array}{c}\mathrm{NO}_{3}-\mathrm{N} \\
(\mathrm{mg} / \mathrm{kg})\end{array}$ & $\begin{array}{l}\text { Bray P } \\
(\mathrm{mg} / \mathrm{kg})\end{array}$ & $\%$ OM \\
\hline \multirow[t]{4}{*}{ CT-OV-G-01 } & 71 & $1,2,3$ & $0-30$ & 166 & 0.4 & 199.3 & 5.13 \\
\hline & 72 & $1,2,3$ & $20-61$ & & & & \\
\hline & 73 & 1 & $25-46$ & & & & \\
\hline & 74 & 1 & $46-61$ & & & & \\
\hline \multirow[t]{4}{*}{ CT-OV-G-02 } & 75 & 1 & $0-30$ & 130 & 2.2 & 45.3 & 0.48 \\
\hline & 76 & 2 & $0-20$ & 174 & 0.5 & 62.5 & 1.11 \\
\hline & 77 & 3 & $0-61$ & 126 & 3.9 & 30.7 & 0.89 \\
\hline & 78 & 2,3 & $20-61$ & & & & \\
\hline \multirow[t]{7}{*}{ CT-OV-G-03 } & 79 & 1,2 & $0-30$ & 740 & 2.4 & 893.2 & 11.79 \\
\hline & 80 & 3 & $0-30$ & 172 & 0.3 & 142.9 & 1.91 \\
\hline & 81 & 1,2 & $15-48$ & & & & \\
\hline & 82 & 3 & $30-51$ & & & & \\
\hline & 83 & 2 & $46-61$ & & & & \\
\hline & 84 & 1 & $48-61$ & & & & \\
\hline & 85 & 3 & $51-61$ & & & & \\
\hline \multirow[t]{6}{*}{ CT-OV-M-01 } & 86 & 1 & $0-30$ & 114 & 0.3 & 63.6 & 1.49 \\
\hline & 87 & 2 & $0-8$ & 1068 & 0.3 & 1466.1 & 22.26 \\
\hline & 89 & 3 & $0-5$ & 282 & 0.6 & 429.7 & 5.59 \\
\hline & 90 & 2,3 & $2-36$ & & & & \\
\hline & 91 & $1,2,3$ & $20-61$ & & & & \\
\hline & 92 & $1,2,3$ & $41-61$ & & & & \\
\hline \multirow[t]{5}{*}{ CT-M-OV-02 } & 93 & $1,2,3$ & $0-30$ & 152 & 0.4 & 181.4 & 7.66 \\
\hline & 95 & 1,3 & $30-61$ & & & & \\
\hline & 96 & 2 & $13-46$ & & & & \\
\hline & 97 & 2 & $46-61$ & & & & \\
\hline & 98 & 3 & $10-41$ & & & & \\
\hline CT-OV-M-03 & 99 & 1,3 & $0-10$ & 148 & 0.3 & 215.4 & 3.44 \\
\hline
\end{tabular}


Table 40. Continued.

\begin{tabular}{|c|c|c|c|c|c|c|c|}
\hline Transect ID & $\begin{array}{c}\text { Sample } \\
\#\end{array}$ & Pit \# & $\begin{array}{c}\text { Depth in } \\
\text { Profile } \\
(\mathrm{cm})\end{array}$ & $\begin{array}{c}\mathrm{K} \\
(\mathrm{mg} / \mathrm{kg})\end{array}$ & $\begin{array}{c}\mathrm{NO}_{3}-\mathrm{N} \\
(\mathrm{mg} / \mathrm{kg})\end{array}$ & $\begin{array}{c}\text { Bray P } \\
(\mathrm{mg} / \mathrm{kg})\end{array}$ & \% OM \\
\hline & 100 & 2 & $0-30$ & 136 & 0.8 & 103.5 & 2.2 \\
\hline & 101 & 1 & $10-61$ & & & & \\
\hline & 102 & 2 & $30-41$ & & & & \\
\hline & 103 & 3 & $20-61$ & & & & \\
\hline CT-OV-P-01 & 104 & 2 & $41-61$ & & & & \\
\hline & 105 & $1,2,3$ & $0-30$ & 86 & 1.5 & 22.8 & 4.81 \\
\hline CT-OV-P-02 & 106 & $1,2,3$ & $30-61$ & & & & \\
\hline & 107 & $1,2,3$ & $0-30$ & 100 & 1.8 & 76 & 9.56 \\
\hline CT-OV-P-03 & 108 & $1,2,3$ & $13-61$ & & & & \\
\hline & 109 & $1,2,3$ & $0-30$ & 62 & 0.7 & 155.6 & 3.44 \\
\hline & 111 & 1,3 & $30-61$ & & & & \\
\hline CT-SB-G-01 & 112 & 2 & $15-61$ & & & & \\
\hline & 113 & $1,2,3$ & $0-15$ & 282 & 1.2 & 455.6 & 5.67 \\
\hline & 115 & 1 & $15-46$ & & & & \\
\hline & 116 & 3 & $8-46$ & & & & \\
\hline CT-SB-G-02 & 117 & $1,2,3$ & $0-15$ & 208 & 5.6 & 318 & 5.64 \\
\hline & 118 & 1,2 & $15-46$ & & & & \\
\hline & 119 & 3 & $10-46$ & & & & \\
\hline CT-SB-G-03 & 120 & 1 & $0-13$ & 566 & 0.4 & 1001.5 & 15.24 \\
\hline & 122 & 2,3 & $0-13$ & 104 & 0.6 & 42.1 & 1.85 \\
\hline & 123 & 1,2 & $13-46$ & & & & \\
\hline & 124 & 3 & $13-46$ & & & & \\
\hline & 125 & 1 & $0-33$ & 114 & 4 & 145.7 & 1.01 \\
\hline & 126 & 2,3 & $0-23$ & 164 & 0.5 & 179.5 & 5.18 \\
\hline & 127 & 1,3 & $33-46$ & & & & \\
\hline & 128 & 2 & $23-46$ & & & & \\
\hline & & & & & & & \\
\hline
\end{tabular}


Table 40. Continued.

\begin{tabular}{|c|c|c|c|c|c|c|c|}
\hline Transect ID & $\begin{array}{c}\text { Sample } \\
\#\end{array}$ & Pit \# & $\begin{array}{c}\text { Depth in } \\
\text { Profile }(\mathrm{cm})\end{array}$ & $\begin{array}{c}\mathrm{K} \\
(\mathrm{mg} / \mathrm{kg})\end{array}$ & $\begin{array}{l}\mathrm{NO}_{3}-\mathrm{N} \\
(\mathrm{mg} / \mathrm{kg})\end{array}$ & $\begin{array}{l}\text { Bray P } \\
(\mathrm{mg} / \mathrm{kg})\end{array}$ & $\%$ OM \\
\hline \multirow[t]{7}{*}{ CT-SB-M-02 } & 129 & 1 & $0-15$ & 122 & 0.6 & 72.6 & 0.79 \\
\hline & 130 & 2 & $0-13$ & 480 & 0.1 & 967.7 & 15.5 \\
\hline & 131 & 3 & $0-10$ & 438 & 0.2 & 825.5 & 13.39 \\
\hline & 132 & 1 & $15-46$ & & & & \\
\hline & 133 & 2 & $13-46$ & & & & \\
\hline & 134 & 3 & $10-36$ & & & & \\
\hline & 135 & 3 & $36-46$ & & & & \\
\hline \multirow[t]{5}{*}{ CT-SB-M-03 } & 136 & $1,2,3$ & $0-20$ & 112 & 0.2 & 102.3 & 1.06 \\
\hline & 138 & 1 & $10-20$ & & & & \\
\hline & 139 & 1 & $20-46$ & & & & \\
\hline & 140 & 2 & $20-46$ & & & & \\
\hline & 141 & 3 & $20-61$ & & & & \\
\hline \multirow[t]{3}{*}{ CT-SB-P-01 } & 142 & $1,2,3$ & $0-20$ & 108 & 3.1 & 38.8 & 5.46 \\
\hline & 143 & 1 & $10-33$ & & & & \\
\hline & 144 & $1,2,3$ & $20-46$ & & & & \\
\hline \multirow[t]{3}{*}{ CT-SB-P-02 } & 145 & $1,2,3$ & $0-8$ & 128 & 0.8 & 19.3 & 1.34 \\
\hline & 146 & 1,3 & $8-46$ & & & & \\
\hline & 147 & 3 & $33-46$ & & & & \\
\hline \multirow[t]{3}{*}{ CT-SB-P-03 } & 148 & 1,3 & $0-46$ & 94 & 0.4 & 39.4 & 0.47 \\
\hline & 149 & 2 & $0-30$ & 76 & 0.4 & 1.6 & $<.05$ \\
\hline & 150 & 2 & $30-46$ & & & & \\
\hline Sample \#87 dup. & 88 & 2 & $0-8$ & 1090 & 0.4 & 1375.8 & 23.68 \\
\hline Sample \#93 dup. & 94 & $1,2,3$ & $0-30$ & 152 & 0.3 & 133.5 & 6.8 \\
\hline Sample \#109 dup. & 110 & $1,2,3$ & $0-30$ & 64 & 0.7 & 149.3 & 3.3 \\
\hline Sample \#136 dup. & 137 & $1,2,3$ & $0-20$ & 112 & 0.2 & 117.1 & 1.38 \\
\hline
\end{tabular}


Table 41. Soluble metals and As data from subset of topsoil samples collected at the Comet Mine.

\begin{tabular}{|c|c|c|c|c|c|c|c|c|c|c|}
\hline Transect ID & $\begin{array}{c}\text { Sample } \\
\# \\
\end{array}$ & Pit \# & $\begin{array}{l}\text { Depth } \\
\text { in } \\
\text { Profile } \\
\text { (cm) }\end{array}$ & $\mathrm{pH}$ & $E C(\mu S)$ & $\begin{array}{c}\text { Soluble } \\
\mathrm{Cu} \\
(\mathrm{mg} / \mathrm{L})\end{array}$ & $\begin{array}{c}\text { Soluble } \\
\text { Zn } \\
(\mathrm{mg} / \mathrm{L})\end{array}$ & $\begin{array}{c}\text { Soluble } \\
\text { Cd } \\
(\mathrm{mg} / \mathrm{L})\end{array}$ & $\begin{array}{c}\text { Soluble } \\
\text { As } \\
(\mathrm{mg} / \mathrm{L})\end{array}$ & $\begin{array}{c}\text { Soluble } \\
\mathrm{Pb} \\
(\mathrm{mg} / \mathrm{L})\end{array}$ \\
\hline \multirow[t]{4}{*}{ CT-SB-G-01 } & 113 & $1,2,3$ & $0-15$ & 6.43 & & & & & & \\
\hline & 114 & 1 & $15-46$ & & & & & & & \\
\hline & 115 & 2 & $10-46$ & & & & & & & \\
\hline & 116 & 3 & $8-46$ & & & & & & & \\
\hline \multirow[t]{3}{*}{ CT-SB-G-02 } & 117 & $1,2,3$ & $0-15$ & 6.63 & 2143 & 0.24 & 12.57 & 0.11 & 0.32 & 0.4 \\
\hline & 118 & 1,2 & $15-46$ & 6.67 & 2765 & & & & & \\
\hline & 119 & 3 & $10-46$ & & & & & & & \\
\hline \multirow[t]{4}{*}{ CT-SB-G-03 } & 120 & 1 & $0-13$ & 6.54 & 2119 & & & & & \\
\hline & 122 & 2,3 & $0-13$ & 6.64 & 1223 & & & & & \\
\hline & 123 & 1,2 & $13-46$ & 7.08 & 1523 & & & & & \\
\hline & 124 & 3 & $13-46$ & & & & & & & \\
\hline \multirow[t]{4}{*}{ CT-SB-M-01 } & 125 & 1 & $0-33$ & 6.2 & 2507 & & & & & \\
\hline & 126 & 2,3 & $0-23$ & 5.9 & 3176 & 0.11 & 220.91 & 1.86 & 0.21 & 0.4 \\
\hline & 127 & 1,3 & $33-46$ & 6.54 & 3165 & & & & & \\
\hline & 128 & 2 & $23-46$ & & & & & & & \\
\hline \multirow[t]{7}{*}{ CT-SB-M-02 } & 129 & 1 & $0-15$ & 6.72 & 1655 & & & & & \\
\hline & 130 & 2 & $0-13$ & 7.02 & 2117 & & & & & \\
\hline & 131 & 3 & $0-10$ & 7.12 & 1852 & 0.07 & 7.11 & 0.04 & 0.71 & $<.1$ \\
\hline & 132 & 1 & $15-46$ & & & & & & & \\
\hline & 133 & 2 & $13-46$ & & & & & & & \\
\hline & 134 & 3 & $10-36$ & & & & & & & \\
\hline & 135 & 3 & $36-46$ & & & & & & & \\
\hline \multirow[t]{4}{*}{ CT-SB-M-03 } & 136 & $1,2,3$ & $0-20$ & 7.02 & 1834 & & & & & \\
\hline & & & & & & & & & & \\
\hline & 138 & 1 & $10-20$ & & & & & & & \\
\hline & 139 & 1 & $20-46$ & & & & & & & \\
\hline
\end{tabular}


Table 41. Continued.

\begin{tabular}{|c|c|c|c|c|c|c|c|c|c|c|}
\hline Transect ID & $\begin{array}{c}\text { Sample } \\
\#\end{array}$ & Pit \# & $\begin{array}{l}\text { Depth in } \\
\text { Profile } \\
\text { (cm) }\end{array}$ & $\mathrm{pH}$ & $E C(\mu S)$ & $\begin{array}{c}\text { Soluble } \\
\text { Cu } \\
(\mathrm{mg} / \mathrm{L})\end{array}$ & $\begin{array}{c}\text { Soluble } \\
\text { Zn } \\
(\mathrm{mg} / \mathrm{L})\end{array}$ & $\begin{array}{c}\text { Soluble } \\
\text { Cd } \\
(\mathrm{mg} / \mathrm{L})\end{array}$ & $\begin{array}{c}\text { Soluble } \\
\text { As } \\
(\mathrm{mg} / \mathrm{L})\end{array}$ & $\begin{array}{c}\text { Soluble } \\
\mathrm{Pb} \\
(\mathrm{mg} / \mathrm{L})\end{array}$ \\
\hline & 140 & 2 & $20-46$ & & & & & & & \\
\hline & 141 & 3 & $20-61$ & & & & & & & \\
\hline \multirow[t]{3}{*}{ CT-SB-P-01 } & 142 & $1,2,3$ & $0-20$ & 6.09 & 4224 & 0.51 & 552.89 & 5.36 & 0.15 & 1.5 \\
\hline & 143 & 1 & $10-33$ & & & & & & & \\
\hline & 144 & $1,2,3$ & $20-46$ & 6.94 & $5.00 \mathrm{mS}$ & & & & & \\
\hline \multirow[t]{3}{*}{ CT-SB-P-02 } & 145 & $1,2,3$ & $0-8$ & 6.67 & 3375 & & & & & \\
\hline & 146 & 1,3 & $8-46$ & 5.9 & 1669 & & & & & \\
\hline & 147 & 3 & $33-46$ & & & & & & & \\
\hline \multirow{3}{*}{ CT-SB-P-03 } & 148 & 1,3 & $0-46$ & 6.94 & 2020 & & & & & \\
\hline & 149 & 2 & $0-30$ & 7.1 & 1170 & 0.02 & 0.96 & 0.01 & $<.05$ & $<.1$ \\
\hline & 150 & 2 & $30-46$ & & & & & & & \\
\hline \multirow[t]{4}{*}{ CT-OV-G-01 } & 71 & $1,2,3$ & $0-30$ & 6.26 & 2515 & 0.09 & 25.21 & 0.15 & 0.17 & $<.1$ \\
\hline & 72 & $1,2,3$ & $20-61$ & 6.75 & 3068 & & & & & \\
\hline & 73 & 1 & $25-46$ & & & & & & & \\
\hline & 74 & 1 & $46-61$ & & & & & & & \\
\hline \multirow[t]{4}{*}{ CT-OV-G-02 } & 75 & 1 & $0-30$ & 6.43 & 909 & & & & & \\
\hline & 76 & 2 & $0-20$ & 6.28 & 379.5 & & & & & \\
\hline & 77 & 3 & $0-61$ & 6.13 & 1194 & 0.1 & 22.1 & 0.05 & $<.05$ & $<.1$ \\
\hline & 78 & 2,3 & $20-61$ & 6.34 & 1062 & & & & & \\
\hline \multirow[t]{7}{*}{ CT-OV-G-03 } & 79 & 1,2 & $0-30$ & 6.31 & 3007 & & & & & \\
\hline & 80 & 3 & $0-30$ & 6.6 & 3045 & & & & & \\
\hline & 81 & 1,2 & $15-48$ & & & & & & & \\
\hline & 82 & 3 & $30-51$ & & & & & & & \\
\hline & 83 & 2 & $46-61$ & & & & & & & \\
\hline & 84 & 1 & 48-61 & & & & & & & \\
\hline & 85 & 3 & $51-61$ & & & & & & & \\
\hline
\end{tabular}


Table 41. Continued.

\begin{tabular}{|c|c|c|c|c|c|c|c|c|c|c|}
\hline Transect ID & $\begin{array}{c}\text { Sample } \\
\#\end{array}$ & Pit \# & $\begin{array}{l}\text { Depth in } \\
\text { Profile } \\
\text { (cm) }\end{array}$ & $\mathrm{pH}$ & $E C(\mu S)$ & $\begin{array}{c}\text { Soluble } \\
\text { Cu } \\
\text { (mg/L) }\end{array}$ & $\begin{array}{c}\text { Soluble } \\
\text { Zn } \\
(\mathrm{mg} / \mathrm{L})\end{array}$ & $\begin{array}{c}\text { Soluble } \\
\text { Cd } \\
\text { (mg/L) }\end{array}$ & $\begin{array}{c}\text { Soluble } \\
\text { As } \\
(\mathrm{mg} / \mathrm{L})\end{array}$ & $\begin{array}{c}\text { Soluble } \\
\mathrm{Pb} \\
(\mathrm{mg} / \mathrm{L})\end{array}$ \\
\hline \multirow[t]{6}{*}{ CT-OV-M-01 } & 86 & 1 & $0-30$ & 7.21 & 554 & 0.07 & 0.47 & $<.01$ & 0.1 & $<.1$ \\
\hline & 87 & 2 & $0-8$ & 6.53 & 673 & & & & & \\
\hline & 89 & 3 & $0-5$ & 6.69 & 924 & & & & & \\
\hline & 90 & 2,3 & $2-36$ & 6.88 & 818 & & & & & \\
\hline & 91 & $1,2,3$ & $20-61$ & 6.71 & 2585 & & & & & \\
\hline & 92 & $1,2,3$ & $41-61$ & & & & & & & \\
\hline \multirow[t]{5}{*}{ CT-M-OV-02 } & 93 & $1,2,3$ & $0-30$ & 6.11 & 3163 & & & & & \\
\hline & 95 & 1,3 & $30-61$ & 5.94 & 4245 & & & & & \\
\hline & 96 & 2 & $13-46$ & 6.13 & $6.21 \mathrm{mS}$ & & & & & \\
\hline & 97 & 2 & $46-61$ & & & & & & & \\
\hline & 98 & 3 & $10-41$ & & & & & & & \\
\hline \multirow[t]{6}{*}{ CT-OV-M-03 } & 99 & 1,3 & $0-10$ & 6.62 & 2008 & 0.19 & 4.52 & 0.03 & 0.53 & $<.1$ \\
\hline & 100 & 2 & $0-30$ & 6.71 & 3309 & & & & & \\
\hline & 101 & 1 & $10-61$ & & & & & & & \\
\hline & 102 & 2 & $30-41$ & & & & & & & \\
\hline & 103 & 3 & $20-61$ & & & & & & & \\
\hline & 104 & 2 & $41-61$ & & & & & & & \\
\hline \multirow[t]{2}{*}{ CT-OV-P-01 } & 105 & $1,2,3$ & $0-30$ & 6.07 & 3963 & & & & & \\
\hline & 106 & $1,2,3$ & $30-61$ & 5.96 & 4679 & & & & & \\
\hline \multirow[t]{2}{*}{ CT-OV-P-02 } & 107 & $1,2,3$ & $0-30$ & 6.67 & 3815 & & & & & \\
\hline & 108 & $1,2,3$ & $13-61$ & 6.26 & 3299 & 1.23 & 788.58 & 3.67 & 0.18 & 0.5 \\
\hline \multirow[t]{3}{*}{ CT-OV-P-03 } & 109 & $1,2,3$ & $0-30$ & 6.02 & $5.16 \mathrm{mS}$ & & & & & \\
\hline & 111 & 1,3 & $30-61$ & 6.35 & 3381 & & & & & \\
\hline & 112 & 2 & $15-61$ & & & & & & & \\
\hline Sample \#87 dup. & 88 & 2 & $0-8$ & 6.59 & 507 & & & & & \\
\hline
\end{tabular}


Table 41. Continued.

\begin{tabular}{|c|c|c|c|c|c|c|c|c|c|c|}
\hline & Sample & \# & $\begin{array}{c}\text { Depth in } \\
\text { Profile } \\
(\mathrm{cm})\end{array}$ & $\mathrm{pH}$ & $\mathrm{EC}(\mu \mathrm{S})$ & $\begin{array}{c}\text { Soluble } \\
\mathrm{Cu} \\
(\mathrm{mg} / \mathrm{L})\end{array}$ & $\begin{array}{c}\text { Soluble } \\
\mathrm{Zn} \\
(\mathrm{mg} / \mathrm{L})\end{array}$ & $\begin{array}{c}\text { Soluble } \\
\mathrm{Cd} \\
(\mathrm{mg} / \mathrm{L})\end{array}$ & $\begin{array}{c}\text { Soluble } \\
\mathrm{As} \\
(\mathrm{mg} / \mathrm{L})\end{array}$ & $\begin{array}{c}\text { Soluble } \\
\mathrm{Pb} \\
(\mathrm{mg} / \mathrm{L})\end{array}$ \\
\hline $\begin{array}{c}\text { Sample \#93 dup. } \\
\begin{array}{c}\text { Sample \#109 } \\
\text { dup. }\end{array}\end{array}$ & 94 & $1,2,3$ & $0-30$ & 6.27 & 1436 & & & & & \\
\hline $\begin{array}{c}\text { Sample \#136 } \\
\text { dup. }\end{array}$ & 110 & $1,2,3$ & $0-30$ & 6.11 & $5.23 \mathrm{mS}$ & & & & & \\
\hline
\end{tabular}


Table 42. Total metals and As data from topsoil samples collected at the Comet Mine.

\begin{tabular}{|c|c|c|c|c|c|c|c|c|}
\hline Transect ID & $\begin{array}{c}\text { Sample } \\
\#\end{array}$ & Pit \# & $\begin{array}{c}\text { Depth in } \\
\text { Profile (cm) }\end{array}$ & $\mathrm{pH}$ & $\begin{array}{c}\text { Total Cu } \\
(\mathrm{mg} / \mathrm{kg})\end{array}$ & $\begin{array}{l}\text { Total Zn } \\
(\mathrm{mg} / \mathrm{kg})\end{array}$ & $\begin{array}{c}\text { Total As } \\
(\mathrm{mg} / \mathrm{kg})\end{array}$ & $\begin{array}{c}\text { Total Pb } \\
(\mathrm{mg} / \mathrm{kg})\end{array}$ \\
\hline \multirow[t]{4}{*}{ CT-OV-G-01 } & 71 & $1,2,3$ & $0-30$ & 6.26 & 325 & 7134 & 1483 & 2702 \\
\hline & 72 & $1,2,3$ & $20-61$ & 6.75 & & & & \\
\hline & 73 & 1 & $25-46$ & & & & & \\
\hline & 74 & 1 & $46-61$ & & & & & \\
\hline \multirow[t]{4}{*}{ CT-OV-G-02 } & 75 & 1 & $0-30$ & 6.43 & 110 & 1164 & 290 & 422 \\
\hline & 76 & 2 & $0-20$ & 6.28 & 208 & 1169 & 267 & 617 \\
\hline & 77 & 3 & $0-61$ & 6.13 & 177 & 1251 & 142 & 422 \\
\hline & 78 & 2,3 & $20-61$ & 6.34 & & & & \\
\hline \multirow[t]{7}{*}{ CT-OV-G-03 } & 79 & 1,2 & $0-30$ & 6.31 & 814 & 3835 & 1420 & 4194 \\
\hline & 80 & 3 & $0-30$ & 6.6 & 381 & 3488 & 1911 & 2305 \\
\hline & 81 & 1,2 & $15-48$ & & & & & \\
\hline & 82 & 3 & $30-51$ & & & & & \\
\hline & 83 & 2 & $46-61$ & & & & & \\
\hline & 84 & 1 & $48-61$ & & & & & \\
\hline & 85 & 3 & $51-61$ & & & & & \\
\hline \multirow[t]{6}{*}{ CT-OV-M-01 } & 86 & 1 & $0-30$ & 7.21 & 62.2 & 640 & 193 & 591 \\
\hline & 87 & 2 & $0-8$ & 6.53 & 421 & 1453 & 298 & 679 \\
\hline & 89 & 3 & $0-5$ & 6.69 & 191 & 1789 & 589 & 939 \\
\hline & 90 & 2,3 & $2-36$ & 6.88 & & & & \\
\hline & 91 & $1,2,3$ & $20-61$ & 6.71 & & & & \\
\hline & 92 & $1,2,3$ & $41-61$ & & & & & \\
\hline \multirow[t]{5}{*}{ CT-M-OV-02 } & 93 & $1,2,3$ & $0-30$ & 6.11 & 373 & 4354 & 1816 & 2179 \\
\hline & 95 & 1,3 & $30-61$ & 5.94 & & & & \\
\hline & 96 & 2 & $13-46$ & 6.13 & & & & \\
\hline & 97 & 2 & $46-61$ & & & & & \\
\hline & 98 & 3 & $10-41$ & & & & & \\
\hline CT-OV-M-03 & 99 & 1,3 & $0-10$ & 6.62 & 422 & 3618 & 2118 & 2963 \\
\hline
\end{tabular}


Table 42. Continued.

\begin{tabular}{|c|c|c|c|c|c|c|c|c|}
\hline Transect ID & $\begin{array}{c}\text { Sample } \\
\#\end{array}$ & Pit \# & $\begin{array}{c}\text { Depth in } \\
\text { Profile }(\mathrm{cm})\end{array}$ & $\mathrm{pH}$ & $\begin{array}{c}\text { Total Cu } \\
(\mathrm{mg} / \mathrm{kg})\end{array}$ & $\begin{array}{c}\text { Total Zn } \\
(\mathrm{mg} / \mathrm{kg})\end{array}$ & $\begin{array}{c}\text { Total As } \\
(\mathrm{mg} / \mathrm{kg})\end{array}$ & $\begin{array}{c}\text { Total Pb } \\
(\mathrm{mg} / \mathrm{kg})\end{array}$ \\
\hline & 100 & 2 & $0-30$ & 6.71 & 352 & 3216 & 1950 & 2110 \\
\hline & 101 & 1 & $10-61$ & & & & & \\
\hline & 102 & 2 & $30-41$ & & & & & \\
\hline & 103 & 3 & $20-61$ & & & & & \\
\hline & 104 & 2 & $41-61$ & & & & & \\
\hline CT-OV-P-01 & 105 & $1,2,3$ & $0-30$ & 6.07 & 1753 & 9273 & 3127 & 11358 \\
\hline & 106 & $1,2,3$ & $30-61$ & 5.96 & & & & \\
\hline CT-OV-P-02 & 107 & $1,2,3$ & $0-30$ & 6.67 & 2605 & 29482 & 10434 & 38927 \\
\hline & 108 & $1,2,3$ & $13-61$ & 6.26 & & & & \\
\hline CT-OV-P-03 & 109 & $1,2,3$ & $0-30$ & 6.02 & 1984 & 39543 & 6537 & 15392 \\
\hline & 111 & 1,3 & $30-61$ & 6.35 & & & & \\
\hline & 112 & 2 & $15-61$ & & & & & \\
\hline CT-SB-G-01 & 113 & $1,2,3$ & $0-15$ & 6.43 & 394 & 4859 & 1400 & 2535 \\
\hline & 114 & 1 & $15-46$ & & & & & \\
\hline & 115 & 2 & $10-46$ & & & & & \\
\hline & 116 & 3 & $8-46$ & & & & & \\
\hline CT-SB-G-02 & 117 & $1,2,3$ & $0-15$ & 6.63 & 532 & 4969 & 1276 & 2040 \\
\hline & 118 & 1,2 & $15-46$ & 6.67 & & & & \\
\hline & 119 & 3 & $10-46$ & & & & & \\
\hline CT-SB-G-03 & 120 & 1 & $0-13$ & 6.54 & 328 & 1968 & 855 & 1163 \\
\hline & 122 & 2,3 & $0-13$ & 6.64 & 214 & 2360 & 993 & 1263 \\
\hline & 123 & 1,2 & $13-46$ & 7.08 & & & & \\
\hline & 124 & 3 & $13-46$ & & & & & \\
\hline & 125 & 1 & $0-33$ & 6.2 & 63.9 & 1465 & 120 & 483 \\
\hline & 126 & 2,3 & $0-23$ & 5.9 & 341 & 11600 & 111 & 3783 \\
\hline & 127 & 1,3 & $33-46$ & 6.54 & & & & \\
\hline & 128 & 2 & $23-46$ & & & & & \\
\hline & & & & & & & & \\
\hline
\end{tabular}


Table 42. Continued.

\begin{tabular}{|c|c|c|c|c|c|c|c|c|}
\hline Transect ID & $\begin{array}{c}\text { Sample } \\
\#\end{array}$ & Pit \# & $\begin{array}{c}\text { Depth in } \\
\text { Profile }(\mathrm{cm})\end{array}$ & $\mathrm{pH}$ & $\begin{array}{c}\text { Total Cu } \\
(\mathrm{mg} / \mathrm{kg})\end{array}$ & $\begin{array}{l}\text { Total Zn } \\
(\mathrm{mg} / \mathrm{kg})\end{array}$ & $\begin{array}{l}\text { Total As } \\
(\mathrm{mg} / \mathrm{kg})\end{array}$ & $\begin{array}{c}\text { Total Pb } \\
(\mathrm{mg} / \mathrm{kg})\end{array}$ \\
\hline \multirow[t]{7}{*}{ CT-SB-M-02 } & 129 & 1 & $0-15$ & 6.72 & 51.3 & 906 & 148 & 493 \\
\hline & 130 & 2 & $0-13$ & 7.02 & 265 & 4772 & 348 & 888 \\
\hline & 131 & 3 & $0-10$ & 7.12 & 282 & 5145 & 792 & 2100 \\
\hline & 132 & 1 & $15-46$ & & & & & \\
\hline & 133 & 2 & $13-46$ & & & & & \\
\hline & 134 & 3 & $10-36$ & & & & & \\
\hline & 135 & 3 & $36-46$ & & & & & \\
\hline \multirow[t]{5}{*}{ CT-SB-M-03 } & 136 & $1,2,3$ & $0-20$ & 7.02 & 69.2 & 1196 & 229 & 591 \\
\hline & 138 & 1 & $10-20$ & & & & & \\
\hline & 139 & 1 & $20-46$ & & & & & \\
\hline & 140 & 2 & $20-46$ & & & & & \\
\hline & 141 & 3 & $20-61$ & & & & & \\
\hline \multirow[t]{3}{*}{ CT-SB-P-01 } & 142 & $1,2,3$ & $0-20$ & 6.09 & 873 & 12755 & 2838 & 8596 \\
\hline & 143 & 1 & $10-33$ & & & & & \\
\hline & 144 & $1,2,3$ & $20-46$ & 6.94 & & & & \\
\hline \multirow[t]{3}{*}{ CT-SB-P-02 } & 145 & $1,2,3$ & $0-8$ & 6.67 & 640 & 21147 & 1387 & 3029 \\
\hline & 146 & 1,3 & $8-46$ & 5.9 & & & & \\
\hline & 147 & 3 & $33-46$ & & & & & \\
\hline \multirow[t]{3}{*}{ CT-SB-P-03 } & 148 & 1,3 & $0-46$ & 6.94 & 270 & 1774 & 1209 & 1282 \\
\hline & 149 & 2 & $0-30$ & 7.1 & 42.3 & 200 & 62 & 68 \\
\hline & 150 & 2 & $30-46$ & & & & & \\
\hline Sample \#87 dup. & 88 & 2 & $0-8$ & 6.59 & 404 & 1405 & 349 & 930 \\
\hline Sample \#93 dup. & 94 & $1,2,3$ & $0-30$ & 6.27 & 363 & 4735 & 1857 & 1778 \\
\hline Sample \#109 dup. & 110 & $1,2,3$ & $0-30$ & 6.11 & 1596 & 25524 & 5730 & 9253 \\
\hline Sample 136 dup. & 137 & $1,2,3$ & $0-20$ & 7.05 & 84 & 1258 & 318 & 793 \\
\hline pure sio2 & 151 & & & & 1 & 3 & $<3$ & $<5$ \\
\hline x-cont blank & 152 & & & & 0.9 & 3 & $<3$ & $<5$ \\
\hline
\end{tabular}


Table 43. Nutrients data from topsoil samples collected at High Ore Creek.

\begin{tabular}{|c|c|c|c|c|c|c|c|}
\hline Transect ID & $\begin{array}{c}\text { Sample } \\
\#\end{array}$ & Pit \# & $\begin{array}{c}\text { Depth in } \\
\text { Profile } \\
\text { (cm) }\end{array}$ & $\begin{array}{c}\mathrm{K} \\
(\mathrm{mg} / \mathrm{kg})\end{array}$ & $\begin{array}{c}\mathrm{NO}_{3}-\mathrm{N} \\
(\mathrm{mg} / \mathrm{kg})\end{array}$ & $\begin{array}{l}\text { Bray P } \\
(\mathrm{mg} / \mathrm{kg})\end{array}$ & $\%$ OM \\
\hline \multirow[t]{2}{*}{ HOC-P-01 } & 53 & $1,2,3$ & $0-10$ & 162 & 0.7 & 403.7 & 5.57 \\
\hline & 54 & $1,2,3$ & $10-51$ & & & & \\
\hline \multirow[t]{2}{*}{ HOC-P-02 } & 55 & $1,2,3$ & $0-38$ & 180 & 5.4 & 312.4 & 3.83 \\
\hline & 56 & $1,2,3$ & $38-61$ & & & & \\
\hline \multirow[t]{3}{*}{ HOC-P-03 } & 57 & $1,2,3$ & $0-13$ & 164 & 2.8 & 191.7 & 4.13 \\
\hline & 59 & $1,2,3$ & $13-33$ & & & & \\
\hline & 60 & 1,3 & $33-51$ & & & & \\
\hline \multirow[t]{4}{*}{ HOC-N-01 } & 61 & 1 & $0-51$ & 54 & 0.2 & 2.7 & 4.83 \\
\hline & 62 & 2 & $0-38$ & 46 & 2.8 & 7.2 & 4.39 \\
\hline & 63 & 3 & $0-30$ & 46 & 6.7 & 64.1 & 2.97 \\
\hline & 64 & 1,3 & $30-51$ & & & & \\
\hline \multirow[t]{2}{*}{ HOC-N-02 } & 65 & $1,2,3$ & $0-61$ & 38 & 1.9 & 17.8 & 1.31 \\
\hline & 66 & 2 & $36-61$ & & & & \\
\hline \multirow[t]{4}{*}{$\mathrm{HOC}-\mathrm{N}-03$} & 67 & 1 & $0-41$ & 48 & 0.2 & 37 & 3.56 \\
\hline & 68 & 2 & $0-41$ & 58 & 0.1 & 42 & 3.04 \\
\hline & 69 & 3 & $0-30$ & 118 & 0.7 & 7.5 & 3.34 \\
\hline & 70 & 3 & $30-61$ & & & & \\
\hline Sample \#57 dup. & 58 & $1,2,3$ & $0-13$ & 152 & 0.8 & 232.4 & 3.95 \\
\hline
\end{tabular}


Table 44. Soluble Metals and As data from topsoil samples collected at High Ore Creek.

\begin{tabular}{|c|c|c|c|c|c|c|c|c|c|c|}
\hline Transect ID & Sample \# & Pit \# & $\begin{array}{c}\text { Depth in } \\
\text { Profile }(\mathrm{cm})\end{array}$ & $\mathrm{pH}$ & $E C(\mu S)$ & $\begin{array}{l}\text { Soluble Cu } \\
(\mathrm{mg} / \mathrm{L})\end{array}$ & $\begin{array}{l}\text { SolubleZn } \\
(\mathrm{mg} / \mathrm{L})\end{array}$ & $\begin{array}{c}\text { Soluble } \\
\mathrm{Cd}(\mathrm{mg} / \mathrm{L})\end{array}$ & $\begin{array}{c}\text { Soluble } \\
\text { As (mg/L) }\end{array}$ & $\begin{array}{c}\text { Soluble } \\
\text { Pb } \\
\text { (mg/L) }\end{array}$ \\
\hline \multirow[t]{2}{*}{ HOC-P-01 } & 113 & $1,2,3$ & $0-10$ & 7.11 & 544 & 0.07 & 0.28 & 0.02 & 0.22 & $<.1$ \\
\hline & 114 & $1,2,3$ & $10-51$ & 7.34 & 404.8 & 0.09 & 0.13 & 0.01 & 0.1 & $<.1$ \\
\hline \multirow[t]{2}{*}{ HOC-P-02 } & 115 & $1,2,3$ & $0-38$ & 7.53 & 404.8 & 0.05 & 0.11 & 0.01 & 0.09 & $<.1$ \\
\hline & 116 & $1,2,3$ & $38-61$ & 7.63 & 294 & 0.09 & 0.28 & 0.02 & 0.13 & 0.1 \\
\hline \multirow[t]{3}{*}{ HOC-P-03 } & 117 & $1,2,3$ & $0-13$ & 7.37 & 353.6 & 0.13 & 0.17 & $<.01$ & 0.59 & $<.1$ \\
\hline & 119 & $1,2,3$ & $13-33$ & 7.21 & 458.8 & 0.18 & 0.21 & $<.01$ & 0.16 & $<.1$ \\
\hline & 120 & 1,3 & $33-51$ & 7.32 & 422.8 & 0.09 & 0.32 & $<.01$ & 0.13 & $<.1$ \\
\hline \multirow[t]{4}{*}{ HOC-N-01 } & 121 & 1 & $0-51$ & 5.48 & 3440 & 0.04 & 161.3 & 0.47 & 0.14 & 0.3 \\
\hline & 122 & 2 & $0-38$ & 6.02 & 1960 & 0.05 & 25.37 & 0.15 & 0.08 & $<.1$ \\
\hline & 123 & 3 & $0-30$ & 6.29 & 1892 & 0.05 & 7.27 & 0.09 & 0.11 & $<.1$ \\
\hline & 124 & 1,3 & $30-51$ & 6.06 & 1664 & 0.01 & 32.6 & 0.09 & 0.07 & $<.1$ \\
\hline \multirow[t]{2}{*}{ HOC-N-02 } & 125 & $1,2,3$ & $0-61$ & 6.27 & 1197 & 0.08 & 12.27 & 0.07 & 0.08 & $<.1$ \\
\hline & 126 & 2 & $36-61$ & 6 & 3306 & 0.06 & 84.36 & 0.14 & 1.87 & 0.4 \\
\hline \multirow[t]{4}{*}{ HOC-N-03 } & 127 & 1 & $0-41$ & 6.34 & 4007 & 0.09 & 22.13 & 0.06 & 0.34 & 0.2 \\
\hline & 128 & 2 & $0-41$ & 5.92 & $5.43 \mathrm{mS}$ & 0.08 & 172.78 & 0.56 & 0.21 & 0.5 \\
\hline & 129 & 3 & $0-30$ & 6.81 & 2933 & 0.14 & 10.83 & 0.02 & 0.2 & $<.1$ \\
\hline & 130 & 3 & $30-61$ & 5.72 & $6.56 \mathrm{mS}$ & 0.03 & 827.88 & 0.27 & 0.26 & 2.5 \\
\hline $\begin{array}{l}\text { Sample } \\
\text { \#117 dup. }\end{array}$ & 118 & $1,2,3$ & $0-13$ & 7.18 & 450.3 & 0.1 & 0.19 & $<.01$ & 0.69 & $<.1$ \\
\hline
\end{tabular}


Table 45. Total metals and As data from topsoil samples collected at High Ore Creek.

\begin{tabular}{|c|c|c|c|c|c|c|c|c|}
\hline Transect ID & $\begin{array}{c}\text { Sample } \\
\#\end{array}$ & Pit \# & $\begin{array}{c}\text { Depth in } \\
\text { Profile } \\
(\mathrm{cm})\end{array}$ & $\mathrm{pH}$ & $\begin{array}{c}\text { Total Cu } \\
(\mathrm{mg} / \mathrm{kg})\end{array}$ & $\begin{array}{c}\text { Total Zn } \\
(\mathrm{mg} / \mathrm{kg})\end{array}$ & $\begin{array}{c}\text { Total As } \\
(\mathrm{mg} / \mathrm{kg})\end{array}$ & $\begin{array}{c}\text { Total Pb } \\
(\mathrm{mg} / \mathrm{kg})\end{array}$ \\
\hline HOC-P-01 & 53 & $1,2,3$ & $0-10$ & 7.11 & 37.8 & 204 & 38 & 64 \\
\hline & 54 & $1,2,3$ & $10-51$ & 7.34 & & & & \\
\hline HOC-P-02 & 55 & $1,2,3$ & $0-38$ & 7.53 & 28.1 & 68 & 9 & 28 \\
\hline & 56 & $1,2,3$ & $38-61$ & 7.63 & & & & \\
\hline HOC-P-03 & 57 & $1,2,3$ & $0-13$ & 7.37 & 103 & 742 & 260 & 726 \\
\hline & 59 & $1,2,3$ & $13-33$ & 7.21 & & & & \\
\hline & 60 & 1,3 & $33-51$ & 7.32 & & & & \\
\hline HOC-N-01 & 61 & 1 & $0-51$ & 5.48 & 702 & 8676 & 4828 & 4914 \\
\hline & 62 & 2 & $0-38$ & 6.02 & & & & \\
\hline & 63 & 3 & $0-30$ & 6.29 & & & & \\
\hline HOC-N-02 & 64 & 1,3 & $30-51$ & 6.06 & & & & \\
\hline & 65 & $1,2,3$ & $0-61$ & 6.27 & 256 & 1490 & 2198 & 1422 \\
\hline HOC-N-03 & 66 & 2 & $36-61$ & 6 & & & & \\
\hline & 68 & 2 & $0-41$ & 5.92 & 625 & 5317 & 4770 & 3159 \\
\hline & 69 & 3 & $0-30$ & 6.81 & 261 & 2517 & 3176 & 1087 \\
\hline & 70 & 3 & $30-61$ & 5.72 & & & & \\
\hline Sample \#57 & 58 & $1,2,3$ & $0-13$ & 7.18 & 74.3 & 399 & 175 & 474 \\
\hline dup. & & & & & & & & \\
\hline
\end{tabular}


APPENDIX D:

ANOVA AND T-TEST OUTPUT 
Gregory Mine ANOVA Tables.

Canopy Cover:

Kruskal-Wallis one-way ANOVA based on Ranks.

\begin{tabular}{cccrrl} 
Group & $\mathrm{N}$ & Missing & Median & $25 \%$ & $75 \%$ \\
\hline Good & 60 & 0 & 125.000 & 102.500 & 157.500 \\
Moderate & 60 & 0 & 77.500 & 57.500 & 93.750 \\
Poor & 60 & 0 & 3.750 & 0.010 & 17.500 \\
H = 131.255 with 2 degrees of freedom. $(\mathrm{P}=<0.001)$ & \\
\hline
\end{tabular}

Biomass Production:

Kruskal-Wallis one-way ANOVA based on Ranks.

\begin{tabular}{crrrrl} 
Group & $\mathrm{N}$ & Missing & Median & $25 \%$ & \multicolumn{1}{c}{$75 \%$} \\
\hline Poor & 42 & 0 & 32.000 & 0.000 & 208.000 \\
Moderate & 42 & 0 & 1076.000 & 905.600 & 1654.400 \\
Good & 42 & 0 & 2305.400 & 1568.000 & 3576.400 \\
& & & & \\
H = 78.448 with 2 degrees of freedom. $(\mathrm{P}=<0.001)$ & \\
\hline
\end{tabular}

Soil H-ion concentration:

Kruskal-Wallis one-way ANOVA based on Ranks.

\begin{tabular}{cccccc} 
Group & $\mathrm{N}$ & Missing & Median & $25 \%$ & $75 \%$ \\
\hline Good & 6 & 0 & 4.64E-6 & $1.48 \mathrm{E}-6$ & $8.51 \mathrm{E}-6$ \\
Moderate & 6 & 0 & $5.12 \mathrm{E}-6$ & $8.51 \mathrm{E}-7$ & $7.76 \mathrm{E}-6$ \\
Poor & 6 & 0 & $2.96 \mathrm{E}-4$ & $1.10 \mathrm{E}-4$ & $8.13 \mathrm{E}-4$ \\
$\mathrm{H}=10.749$ with 2 degrees of freedom. $(\mathrm{P}=<0.001)$ \\
\hline
\end{tabular}


Gregory Mine ANOVA Tables continued.

Soluble Arsenic:

Kruskal-Wallis one-way ANOVA based on Ranks.

\begin{tabular}{rlllll} 
Group & $\mathrm{N}$ & Missing & Median & $25 \%$ & $75 \%$ \\
\hline Good & 13 & 0 & 0.0500 & 0.0500 & 0.153 \\
Moderate & 18 & 0 & 0.155 & 0.0500 & 0.220 \\
Poor & 18 & 0 & 0.255 & 0.200 & 3.450
\end{tabular}

$H=10.969$ with 2 degrees of freedom. $(P=0.004)$

Soluble Cadmium:

Kruskal-Wallis one-way ANOVA based on Ranks.

\begin{tabular}{rrrlrl} 
Group & $\mathrm{N}$ & Missing & Median & $25 \%$ & $75 \%$ \\
\hline Good & 13 & 0 & 0.01000 & 0.01000 & 0.0350 \\
Moderate & 18 & 0 & 0.0250 & 0.01000 & 0.0600 \\
Poor & 18 & 0 & 0.175 & 0.0700 & 0.510
\end{tabular}

$\mathrm{H}=18.882$ with 2 degrees of freedom. $(\mathrm{P}=<0.001)$

Soluble Copper*:

One Way ANOVA

\begin{tabular}{lrrrr} 
Source of Variation & DF & MS & F & P \\
\hline Between Groups & 2 & 4.378 & $8.628<0.001$ \\
Residual & 46 & 0.507 & & \\
Total & 48 & & & \\
\hline
\end{tabular}

* Copper data transformed using $\log _{10}$ transformation. 
Gregory Mine ANOVA Tables continued.

Soluble Zinc:

One Way ANOVA

\begin{tabular}{lllll} 
Source of Variation & DF & MS & F & P \\
\hline
\end{tabular}

Between Groups $\quad 2 \quad 7.29514 .844<0.001$

$\begin{array}{lll}\text { Residual } & 46 & 0.491\end{array}$

Total

48

* Zinc data transformed using $\log _{10}$ transformation.

Sum of Total Metals:

One Way ANOVA

\begin{tabular}{lrlll} 
Source of Variation & DF & MS & F & P \\
\hline Between Groups & 2 & 3680703.104 & 1.484 & 0.258 \\
Residual & 15 & 2480565.016 & & \\
Total & 17 & & & \\
\hline
\end{tabular}

Soil Potassium:

Kruskal-Wallis one-way ANOVA based on Ranks.

\begin{tabular}{rrrrrr} 
Group & N & Missing & Median & $25 \%$ & $75 \%$ \\
\hline Good & 6 & 0 & 248.000 & 238.000 & 366.000 \\
Moderate & 6 & 0 & 237.000 & 162.000 & 276.000 \\
Poor & 6 & 0 & 132.000 & 46.000 & 246.000
\end{tabular}

$\mathrm{H}=4.016$ with 2 degrees of freedom. $(\mathrm{P}=0.134)$ 
Gregory Mine ANOVA Tables continued.

Soil Nitrogen:

Kruskal-Wallis one-way ANOVA based on Ranks.

\begin{tabular}{cccccc} 
Group & N & Missing & Median & $25 \%$ & $75 \%$ \\
\hline Good & 6 & 0 & 0.400 & 0.300 & 5.800 \\
Moderate & 6 & 0 & 0.400 & 0.300 & 0.500 \\
Poor & 6 & 0 & 0.300 & 0.200 & 0.400 \\
\multicolumn{7}{l}{ H = 1.377 with 2 degrees of freedom. (P = 0.502) } \\
\hline
\end{tabular}

Soil Phosphorous:

One Way ANOVA

\begin{tabular}{lrccc} 
Source of Variation & DF & MS & F & P \\
\hline Between Groups & 2 & 385.805 & 1.766 & 0.205 \\
Residual & 15 & 218.477 & & \\
Total & 17 & & & \\
\hline
\end{tabular}

Soil Organic Matter:

One Way ANOVA

\begin{tabular}{lrccc} 
Source of Variation & DF & MS & F & P \\
\hline Between Groups & 2 & 9.642 & 2.612 & 0.106 \\
Residual & 15 & 3.692 & & \\
Total & 17 & & & \\
\hline
\end{tabular}


Comet Mine ANOVA Tables.

Canopy Cover:

Kruskal-Wallis one-way ANOVA based on Ranks.

\begin{tabular}{cccrrl} 
Group & $\mathrm{N}$ & Missing & Median & $25 \%$ & $75 \%$ \\
\hline Good & 60 & 0 & 77.500 & 62.500 & 87.500 \\
Moderate & 60 & 0 & 37.500 & 27.500 & 45.000 \\
Poor & 60 & 0 & 0.000 & 0.000 & 2.500 \\
H = 144.879 with 2 degrees of freedom. $(\mathrm{P}=<0.001)$ & \\
\hline
\end{tabular}

Biomass Production:

Kruskal-Wallis one-way ANOVA based on Ranks.

\begin{tabular}{cccrrl} 
Group & $\mathrm{N}$ & Missing & Median & $25 \%$ & $75 \%$ \\
\hline Good & 60 & 0 & 10.110 & 5.505 & 16.810 \\
Moderate & 60 & 0 & 2.435 & 1.560 & 4.475 \\
Poor & 60 & 0 & 0.000 & 0.000 & 0.000 \\
H = 142.850 with 2 degrees of freedom. $(\mathrm{P}=<0.001)$ \\
\hline
\end{tabular}

Sum of Total Metals*:

One Way ANOVA

\begin{tabular}{lrrrr} 
Source of Variation & DF & MS & F & P \\
\hline Between Groups & 2 & 313.587 & 6.976 & 0.007 \\
Residual & 15 & 44.951 & & \\
Total & 17 & & & \\
\hline
\end{tabular}

* Sum of total meals data transformed using a cube root transformation. 
Comet ANOVA Tables continued.

Soil Potassium:

One Way ANOVA

\begin{tabular}{lrcrl} 
Source of Variation & DF & MS & F & P \\
\hline Between Groups & 2 & 48101.072 & 3.844 & 0.045 \\
Residual & 15 & 12512.903 & & \\
Total & 17 & & & \\
\hline
\end{tabular}

Soil Nitrogen*:

One Way ANOVA

\begin{tabular}{lrccc} 
Source of Variation & DF & MS & F & P \\
\hline Between Groups & 2 & 0.528 & 5.193 & 0.019 \\
Residual & 15 & 0.102 & & \\
Total & 17 & & & \\
\hline
\end{tabular}

* Nitrogen data transformed using a $\log _{10}$ transformation.

Soil Phosphorous:

One Way ANOVA

\begin{tabular}{lrrrr} 
Source of Variation & DF & MS & F & P \\
\hline Between Groups & 2 & 150747.102 & 4.392 & 0.032 \\
Residual & 15 & 34326.573 & & \\
Total & 17 & & & \\
\hline
\end{tabular}

Soil Organic Matter:

One Way ANOVA

\begin{tabular}{lrrrr} 
Source of Variation & DF & \multicolumn{1}{c}{ MS } & F & P \\
\hline Between Groups & 2 & 4.226 & 0.390 & 0.684 \\
Residual & 15 & 10.832 & & \\
Total & 17 & & & \\
\hline
\end{tabular}


High Ore Creek t-test Tables.

Canopy Cover:

Mann-Whitney Rank Sum Test

\begin{tabular}{lccccc} 
Group & $\mathrm{N}$ & Missing & Median & $25 \%$ & $75 \%$ \\
\hline Partial & 30 & 0 & 67.500 & 55.00082 .500 \\
No Removal & 30 & 0 & 63.750 & 32.50090 .000 \\
$\quad \mathrm{~T}=973.500 \mathrm{n}=30$ & $\mathrm{~N}=30 \quad(\mathrm{P}=0.391)$ & \\
\hline
\end{tabular}

Biomass Production:

Mann-Whitney Rank Sum Test

\begin{tabular}{lccrrr} 
Group & $\mathrm{N}$ & Missing & Median & $25 \%$ & $75 \%$ \\
\hline Partial & 30 & 0 & 8.415 & 6.710 & 11.020 \\
No Removal & 30 & 0 & 8.990 & 3.500 & 13.910 \\
$\quad \mathrm{~T}=931.000$ & $\mathrm{n}=30$ & $\mathrm{~N}=30 \quad(\mathrm{P}=0.819)$ & & \\
\hline
\end{tabular}

Soluble As:

Mann-Whitney Rank Sum Test

\begin{tabular}{lccccc} 
Group & $\mathrm{N}$ & Missing & Median & $25 \%$ & $75 \%$ \\
\hline No Removal & 10 & 0 & 0.170 & 0.08000 .260 \\
Partial & 8 & 0 & 0.145 & 0.115 & 0.405 \\
$\quad \mathrm{~T}=80.000$ & $\mathrm{n}=8 \mathrm{~N}=10$ & $(\mathrm{P}=0.756)$ & & \\
\hline
\end{tabular}

Soluble Cadmium:

Mann-Whitney Rank Sum Test

\begin{tabular}{lcllll} 
Group & $\mathrm{N}$ & Missing & Median & $25 \%$ & $75 \%$ \\
\hline No Removal & 10 & 0 & 0.115 & 0.0700 & 0.270 \\
Partial & 8 & 0 & 0.01000 & 0.01000 & 0.0150 \\
$\quad \mathrm{~T}=37.000$ & $\mathrm{n}($ small $)=8$ & $\mathrm{n}(\mathrm{big})=10$ & $(\mathrm{P}=<0.001)$ & \\
\hline
\end{tabular}


High Ore Creek t-test Tables continued.

Soluble Copper:

t-test

Group Name N Missing Mean Std Dev SEM

\begin{tabular}{lccccc}
\hline No Removal & 10 & 0 & 0.0630 & 0.0365 & 0.0116 \\
Partial & 8 & 0 & 0.1000 & 0.0396 & 0.0140 \\
$\mathrm{t}=-2.057$ & with 16 degrees of freedom. $(\mathrm{P}=0.056)$ \\
\hline
\end{tabular}

Soluble Zn:

Mann-Whitney Rank Sum Test

\begin{tabular}{|c|c|c|c|c|}
\hline Group & $\mathrm{N}$ & Missing & Median & $25 \%$ \\
\hline No Removal & 10 & 0 & 28.985 & 12.270161 .300 \\
\hline Partial & 8 & 0 & 0.200 & 0.1500 .280 \\
\hline
\end{tabular}

Sum of Total Metals*:

t-test

Group Name N Missing Mean Std Dev SEM

$\begin{array}{llllll}\text { Partial Trans } & 3 & 0 & 2.641 & 0.577 & 0.333\end{array}$

$\begin{array}{llllll}\text { No Trans } & 3 & 0 & 4.029 & 0.279 & 0.161\end{array}$

$\mathrm{t}=-3.753$ with 4 degrees of freedom. $(\mathrm{P}=0.020)$

* Sum of total metals data transformed using a $\log _{10}$ transformation.

Soil Potassium:

t-test

Group Name N Missing Mean Std Dev SEM

\begin{tabular}{lllrrr}
\hline Partial & 3 & 0 & 168.667 & 9.866 & 5.696 \\
No Removal & 3 & 0 & 53.800 & 18.874 & 10.897 \\
$\mathrm{t}=9.342$ & with & degrees of freedom. $(\mathrm{P}=<0.001)$ \\
\hline
\end{tabular}


High Ore Creek t-test Tables continued.

Soil Nitrogen:

t-test

Group Name N Missing Mean Std Dev SEM

\begin{tabular}{llllll}
\hline Partial & 3 & 0 & 2.967 & 2.354 & 1.359 \\
No Removal & 3 & 0 & 1.800 & 1.453 & 0.839 \\
$\mathrm{t}=0.730$ & with & 4 degrees of freedom. $(\mathrm{P}=0.506)$ \\
\hline
\end{tabular}

Soil Phosphorous*:

t-test

\begin{tabular}{llcccc} 
Group Name & $\mathrm{N}$ & Missing & Mean & Std Dev & SEM \\
\hline Partial & 3 & 0 & 2.461 & 0.164 & 0.0949 \\
No Removal & 3 & 0 & 1.368 & 0.107 & 0.0616 \\
$\mathrm{t}=9.667$ & with & 4 degrees of freedom. $(\mathrm{P}=<0.001)$ \\
\hline
\end{tabular}

* Soil phosphorous data transformed using a $\log _{10}$ transformation.

Soil Organic Matter:

t-test

\begin{tabular}{llcrrr} 
Group Name & $\mathrm{N}$ & Missing & Mean & Std Dev & SEM \\
\hline Partial & 3 & 0 & 4.510 & 0.930 & 0.537 \\
No Removal & 3 & 0 & 2.903 & 1.437 & 0.829 \\
$\quad \mathrm{t}=1.626$ & with 4 degrees of freedom. $(\mathrm{P}=0.179)$ \\
\hline
\end{tabular}

Soil H-ion concentration:

t-test

\begin{tabular}{llcccc} 
Group Name & $N$ & Missing & Mean & Std Dev & \multicolumn{1}{c}{ SEM } \\
\hline NR & 3 & 0 & 0.000000912 & 0.000000591 & 0.000000341 \\
PR & 3 & 0 & 0.0000000499 & 0.0000000249 & 0.0000000144 \\
\multicolumn{1}{l}{$\mathrm{t}=2.523$} & with 4 degrees of freedom. $(\mathrm{P}=0.065)$ & \\
\hline
\end{tabular}

